\title{
CHARACTERIZATION REPORT FOR THE 92-ACRE AREA OF THE AREA 5 RADIOACTIVE WASTE MANAGEMENT SITE, NEVADA TEST SITE, NEVADA
}

Revision: 0

June 2006

Prepared for the U. S. Department of Energy National Nuclear Security Administration Nevada Site Office

Work Performed Under Contract No. DE-AC08-96NV11718 


\section{DISCLAIMER}

Reference herein to any specific commercial product, process, or service by trade name, trademark, manufacturer, or otherwise, does not necessarily constitute or imply its endorsement, recommendation, or favoring by the U.S. Government or any agency thereof or its contractors or subcontractors.

This report has been reproduced directly from the best available copy.

Available for sale to the public from:

U.S. Department of Commerce

National Technical Information Service

5285 Port Royal Road

Springfield, VA 22161-0002

Telephone: (800) 553-6847

Fax: (703) 605-6900

E-mail: orders@ntis.gov

Online ordering: http://www.ntis.gov/ordering.htm

Available electronically at http://www.osti.gov/bridge.

Available for a processing fee to the U.S. Department of Energy and its contractors, in paper, from:

U.S. Department of Energy

Office of Scientific and Technical Information

P.O. Box 62

Oak Ridge, TN 37831-0062

Telephone: (865) 576-8401

Fax: (865) 576-5728

E-mail: reports@adonis.osti.gov 


\section{CHARACTERIZATION REPORT FOR THE 92-ACRE AREA OF THE AREA 5 RADIOACTIVE WASTE MANAGEMENT SITE, NEVADA TEST SITE, NEVADA}

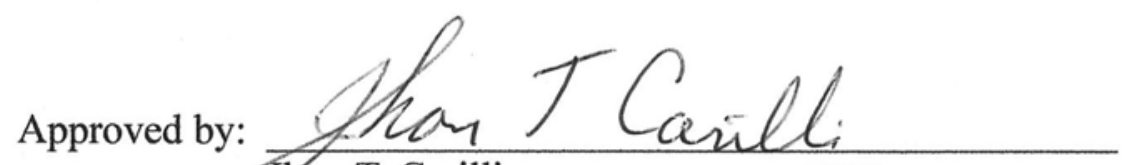
Thon T. Carilli Low-Level Waste Federal Sub-Project Director Waste Management Project

Approved by: for Angela P. Colarusso
Acting Federal Project Director
Waste Management Project

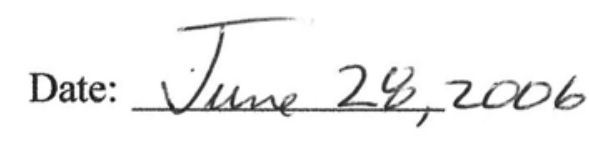





\section{EXECUTIVE SUMMARY}

The U.S. Department of Energy (DOE), National Nuclear Security Administration Nevada Site Office (NNSA/NSO) manages two low-level Radioactive Waste Management Sites (RWMSs) at the Nevada Test Site (NTS). The Area 5 RWMS uses engineered shallow-land burial cells to dispose of packaged waste. This report summarizes characterization and monitoring work pertinent to the 92-Acre Area in the southeast part of the Area 5 RWMS. The southeast quadrant covers 37 hectare (ha) (92 acres [ac]), and is referred to as the "92-Acre Area."

The cells in the 92-Acre Area include 13 boreholes, 16 narrow trenches, and 9 broader pits. The waste disposal units were gradually established during 45 years of waste operations. Only three disposal units within the 92-Acre Area are currently active. Most of the disposal units have been operationally closed with covers of at least 2.4 meters $(\mathrm{m})$ (8 feet [ft]) of native fill. Closure of the 92-Acre Area disposal units is anticipated by 2011.

Current closure plans organize the disposal cells of the 92-Acre Area into six closure units by physical location, waste types, and regulatory requirements. One of these closure units is Federal Facility Agreement and Consent Order Corrective Action Unit (CAU) 111: Retired Mixed Waste Pits. The CAU 111 pits and trenches were operated prior to the promulgation of the Resource Conservation and Recovery Act (RCRA) and may have received both low-level waste (LLW) and low-level mixed waste (LLMW). A proposed single final closure cover and a monitoring plan will meet the needs of all six closure units within the 92-Acre Area. Studies indicate a monolayer soil cover will provide the equivalent protection of a standard RCRA cover, and offer superior performance with respect to subsidence.

The precursor to the Area 5 RWMS, the Sugar Bunker Dump, began receiving waste by 1960 and began burying waste in January 1961. The Area 5 RWMS was established in 1978 on a 296 ha (732-ac) site incorporating the existing Sugar Bunker Dump waste cells in the southeast corner. The thirteen 37-m (120-ft) boreholes were drilled in the 1980s for the Greater Confinement Disposal (GCD) program. The GCD program was terminated before all the boreholes were used.

Both classified and unclassified materials are managed at this facility. Unclassified disposal records and historic records indicate waste types in the 92-Acre Area include LLW, LLMW, asbestiform waste, transuranic (TRU) waste, and mixed TRU waste. Most of the inventory is LLW, and much of the LLW contains radionuclides that will decay significantly over the next several decades. Most of the TRU and potential mixed TRU waste is in boreholes over $21 \mathrm{~m}$ (70 ft) below ground surface. Thorium waste is present in the lowest tier of one disposal pit. Two disposal units have been designated for asbestos waste. Much of the suspected LLMW was deposited at the oldest disposal units prior to the promulgation of RCRA. The contaminants are not readily released or transported, due to the structure (such as lead shielding). The waste acceptance criteria, packaging requirements, monitoring, and other factors in the operation of the interim status RCRA-permitted P03U Mixed Waste Disposal Unit minimize the potential for release and transport of hazardous contaminants from the P03U closure unit. 
Much of the radioactivity in the inventory is in relatively immobile forms, with the exception of tritium, a volatile radionuclide which can readily move with water. Most of the tritium inventory is located in containers within a single disposal cell, GCD-05U. The movement of water through the near-surface environment, and the potential for tritium transport and release, have been assessed in detail. Tritium levels in soil gas, groundwater, air, and biota in the vicinity are monitored. Although tritium has been detected in soil gas below $15 \mathrm{~m}$ (50 ft) depth near the waste packages, air monitoring and biota monitoring at the Area 5 RWMS suggest that very little, if any, tritium has migrated from the buried waste to ground surface.

Monitoring programs near or at the Area 5 RWMS include direct radiation, air quality, vadose zone moisture, soil gas, biota, groundwater quality, meteorological parameters, and waste-cover subsidence. The programs document environmental conditions, document the performance of the operational soil covers, and provide input parameters for the water balance and performance models. Results to date indicate there has been no significant release of radionuclides to the atmosphere, the plants, or groundwater. Radon flux levels near the waste cells have been consistently at least five times lower than the federal performance objectives and regulatory standards. Direct radiation exposure levels at the facility are very low. Moisture infiltration in the soil covers has been effectively mitigated by evapotranspiration. Settling of the operational covers has been monitored and promptly corrected to mitigate potential erosion.

Over the past few decades, NNSA/NSO and its contractors have produced many documents that summarize pertinent characterization, modeling, and monitoring data. The scope of studies is both broad and detailed, from regional hydrogeological modeling and natural hazard potential evaluations, to the evaluation of the potential for termite and ant communities at the Area 5 RWMS to bring radionuclides to the ground surface. This summary highlights some of the most relevant characterization data. For further details, several key studies, and the Performance Assessment (PA) and the Composite Analysis for the Area 5 RWMS are referenced.

The Area 5 RWMS setting is well-suited for the isolation and disposal of waste. The Area 5 RWMS is located in an access-controlled government facility many miles from residential populations. The site has a windy, arid climate. Average annual potential evapotranspiration (PET) measured from 1995 through 2004 was 152.87 centimeters (60.19 inches). Mean evapotranspiration rates are many times the mean precipitation rates. The ratio of PET to precipitation ranged from 6 to 54 and averaged 17 over the 10 years of record. On an annual basis, even in wet cool years, evaporative demand is high.

The site is far from surface-water supplies. Surface runoff and run-on are insignificant, and engineering evaluations of existing structures indicate a 25-year flood event can be controlled in accordance with RCRA flood-protection requirements.

Risks of significant earthquakes and volcanic hazards at the site are low. Minor subsidence of the ground surface above the edges of waste containers and the margins of the cells is likely; however, this localized subsidence can be mitigated by careful placement of containers and cover fill, and through monitoring and maintaining covers at older cells. 
The potential for infiltration of water into the waste material and erosion or biological disturbance of the waste is low. The potential for waste disturbance is mitigated by the facility design and setting. Potential for significant transport or release of contaminants from the waste deposits are minimized by:

- Waste characteristics,

- Soil-cover characteristics,

- Depth of waste burial,

- Shallow plant rooting depths,

- Shallow animal burrow depths,

- Great depth to groundwater,

- Lack of significant surface water runoff,

- Flood mitigation features,

- High evapotranspiration rates,

- Low precipitation rates,

- Alkaline soils, and

- Low risk of significant natural hazards.

Effectively, there is no groundwater pathway. The shallow waste-disposal units are in thick deposits of sandy and silty alluvium. Depth to groundwater is over $230 \mathrm{~m}$ (755 ft).

Environmental tracers, water potential, and other data suggest there is a zone of upward water movement that extends as much as $35 \mathrm{~m}(115 \mathrm{ft})$ deep, underlain by a thick static zone where there is no free gravitational flow. Potential vertical water movement rates through the relatively dry alluvium are slow. The average time modeled for unretarded flow, from the bottom of the static zone to the capillary fringe of the groundwater table, was over 55,000 years. The potential for groundwater recharge in the vicinity of the Area 5 RWMS is extremely low. Consequently, the potential for groundwater contamination from waste disposal activities at the Area 5 RWMS is negligible.

The principle potential processes for upward movement of contaminants away from the buried waste containers to the ground surface and atmosphere include:

- Transport of soluble radionuclides by liquid advection and diffusion by retardation,

- Transport of particulate and soluble radionuclides by plant uptake and animal burrowing, movement of gaseous radionuclides via diffusion and with the moisture, and

- Inadvertent intrusions.

Sufficient information is available about the site's physical, chemical, hydrological, plant, animal, and climate characteristics, as well as facility design, operation, and source materials to provide the input data necessary to complete the PAs and Composite Analysis, taking into account these transport processes. Assessments and analyses indicate that the Area 5 RWMS will meet the DOE regulatory performance criteria for the 1,000-year compliance period. Predicted potential human exposures for various future potential land-use scenarios are negligible. 
The decades of characterization and assessment work at the Area 5 RWMS indicate that the access controls, waste operation practices, site design, final cover design, site setting, and arid natural environment contribute to a containment system that meets regulatory requirements and performance objectives for the short- and long-term protection of the environment and public. The available characterization and PA information is adequate to support design of the final cover and development of closure plans. No further characterization is warranted to demonstrate regulatory compliance. NNSA/NSO is proceeding with the development of closure plans for the six closure units of the 92-Acre Area. 


\section{TABLE OF CONTENTS}

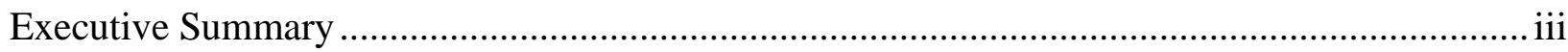

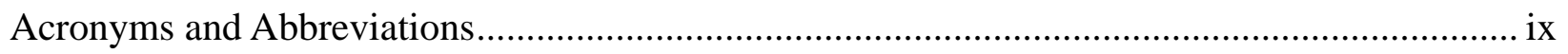

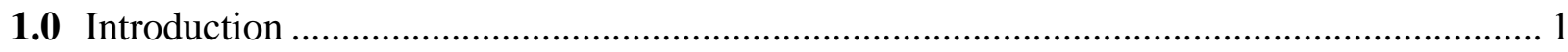

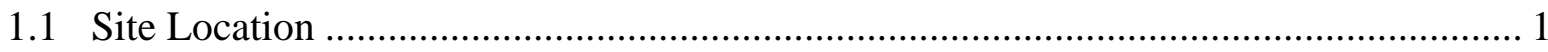

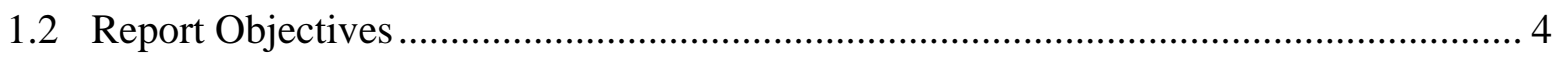

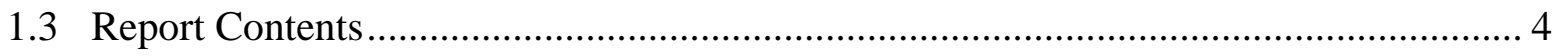

2.0 Location, Layout, and Waste Unit Status ................................................................ 5

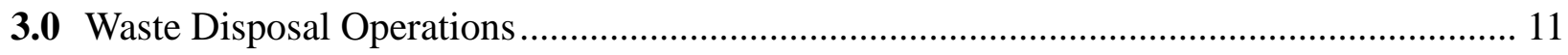

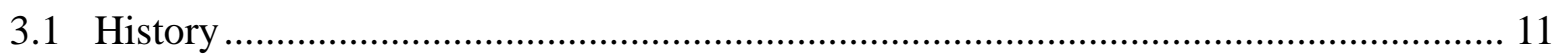

3.2 Waste Acceptance Criteria............................................................................. 14

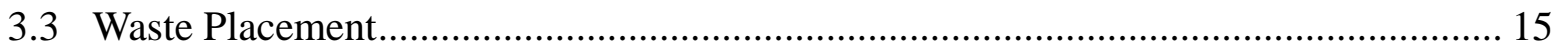

3.4 Waste Containers ............................................................................................. 17

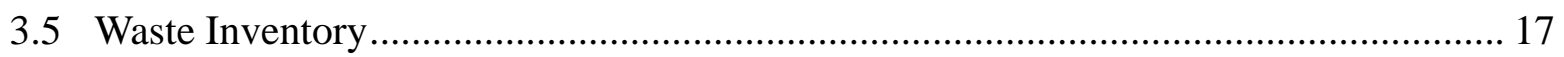

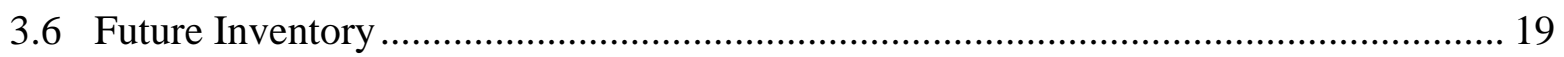

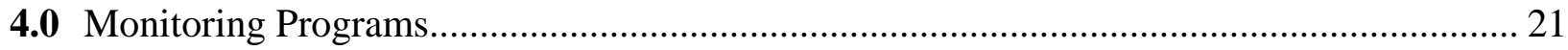

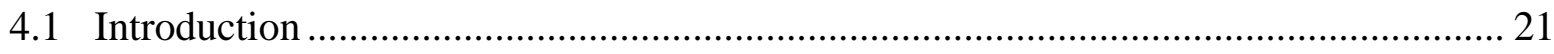

4.2 Monitoring During Operational Closure .............................................................. 22

4.3 Monitoring During Final Closure and Active Institutional Control ........................... 23

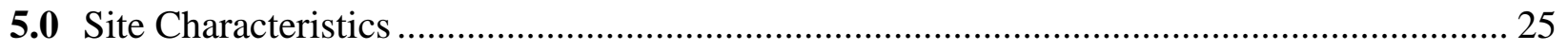

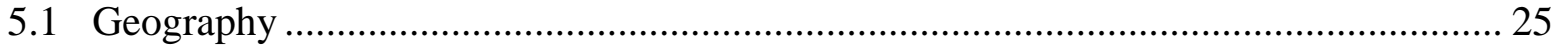

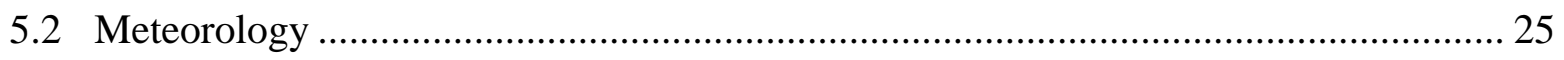

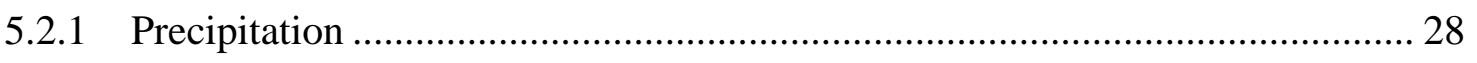

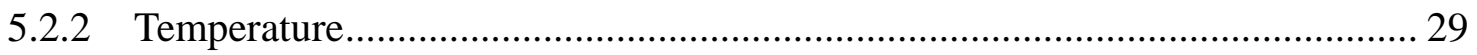

5.2.3 Potential Evapotranspiration .................................................................. 29

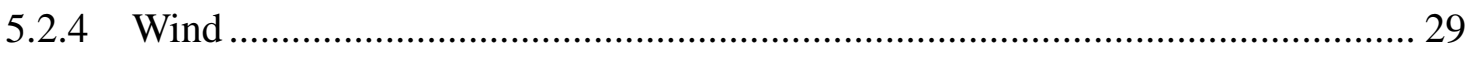

5.3 Vegetation (Flora) and Wildlife (Fauna) .......................................................... 31

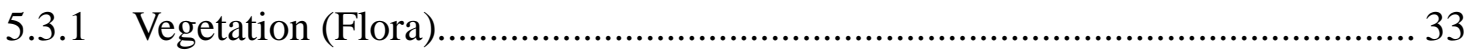

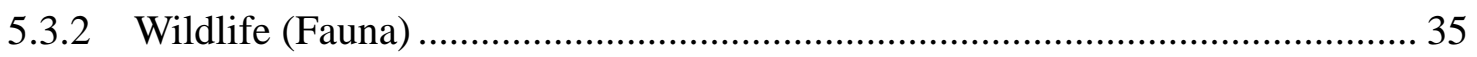

5.3.3 Biota Monitoring................................................................................. 36 


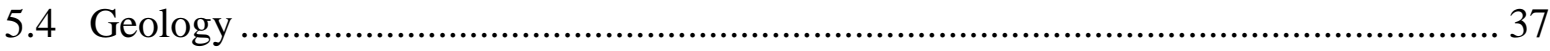

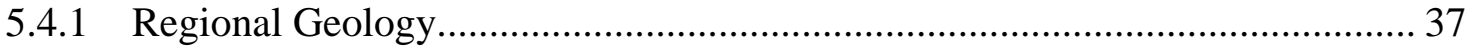

5.4.2 Frenchman Flat Geology ...................................................................... 38

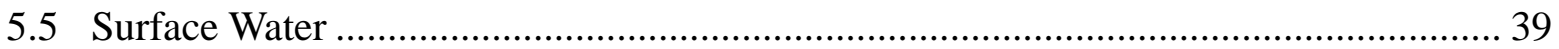

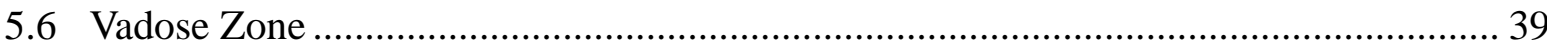

5.6.1 Key Studies Regarding Vadose-Zone Properties .............................................. 39

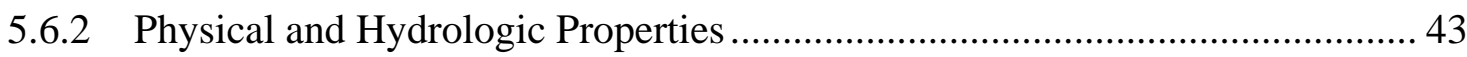

5.6.2.1 Particle Size Distribution/Soil Classification Data ................................. 43

5.6.2.2 Mineral Composition and Geochemistry ............................................. 45

5.6.2.3 Dry Bulk Density .......................................................................... 46

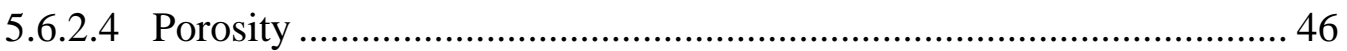

5.6.2.5 Saturated Hydraulic Conductivity........................................................ 47

5.6.2.6 Water Potential, Water Characteristic Curves, and Unsaturated Hydraulic Conductivity ................................................... 48

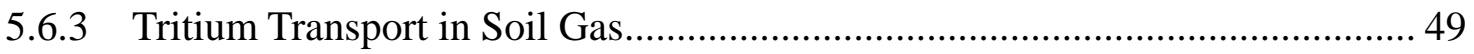

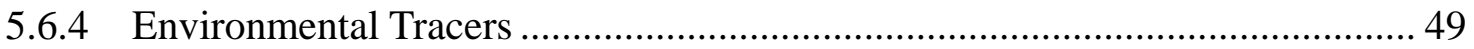

5.6.4.1 Chloride and Bromide.................................................................... 49

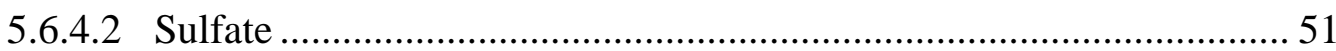

5.6.4.3 Stable Isotopes of Hydrogen and Oxygen ........................................ 51

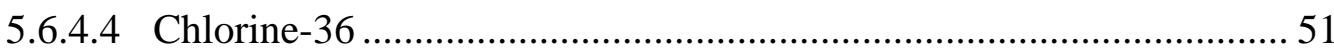

5.6.5 Vadose Zone Water Balance Monitoring......................................................... 52

5.6.5.1 Soil Moisture Monitoring …………………….................................. 52

5.6.5.2 Area 5 Weighing Lysimeter Facility Evapotranspiration, Evaporation, and Storage Data ........................................................ 54

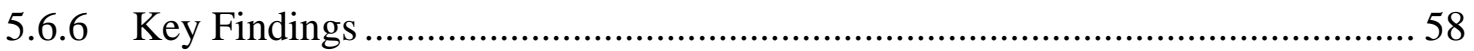

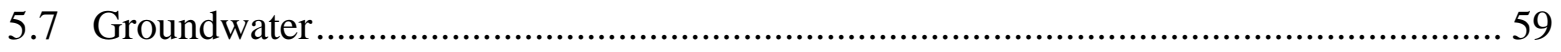

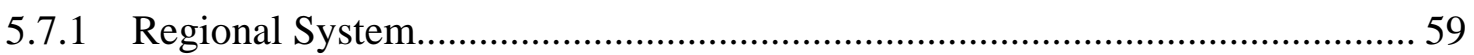

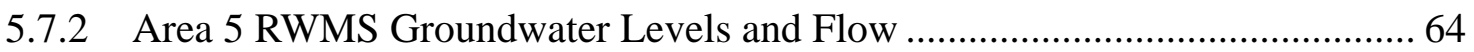

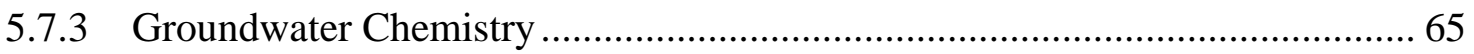

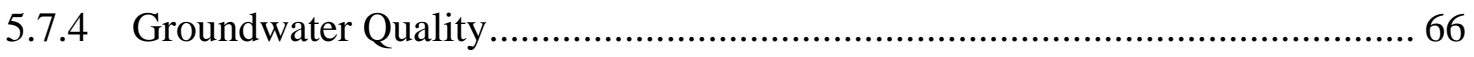

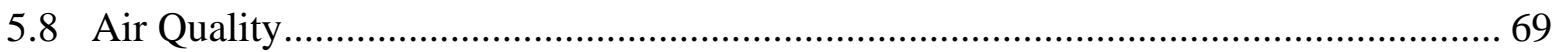

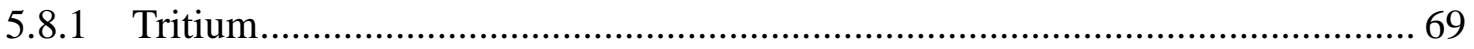

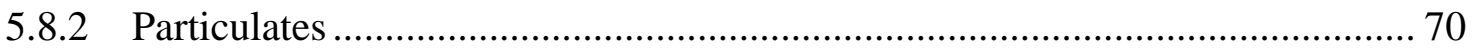

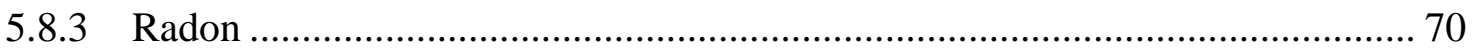

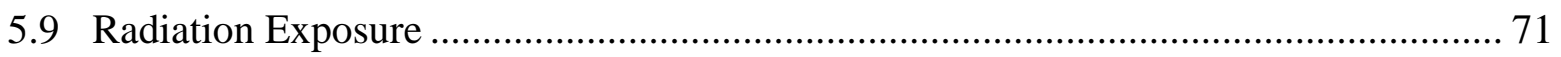




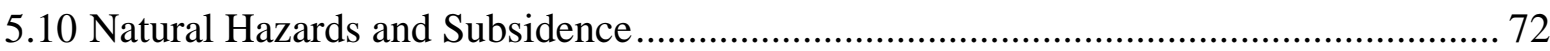

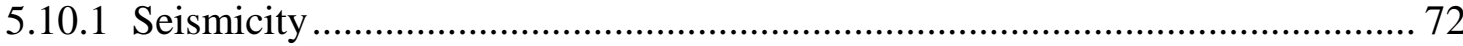

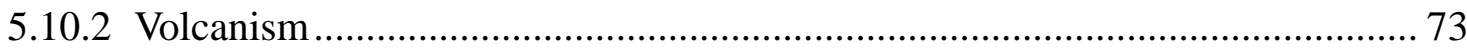

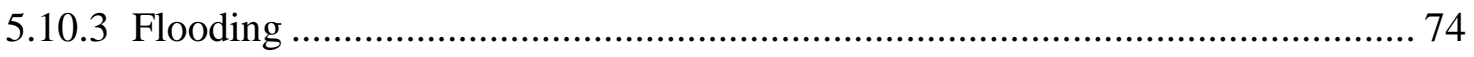

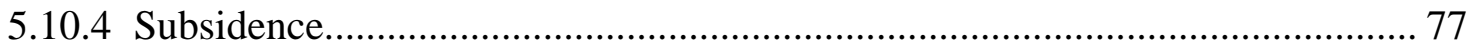

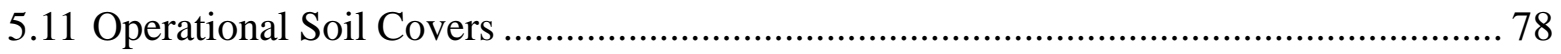

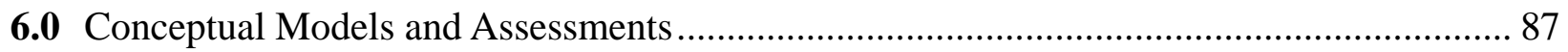

6.1 Hydrologic Conceptual Models for the Area 5 RWMS .......................................... 87

6.2 Performance Assessment and Composite Analysis .............................................. 90

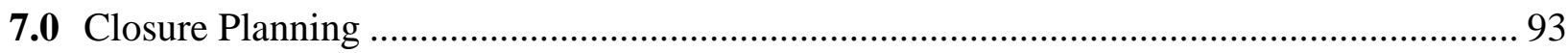

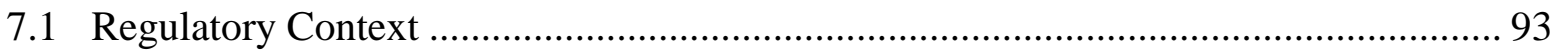

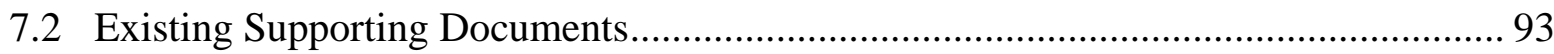

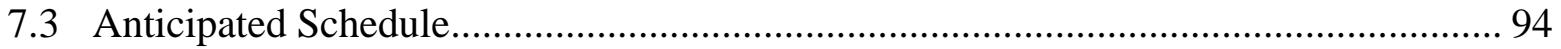

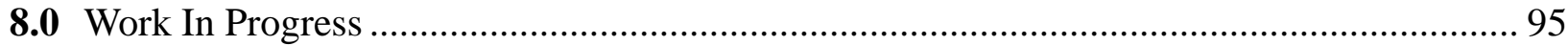

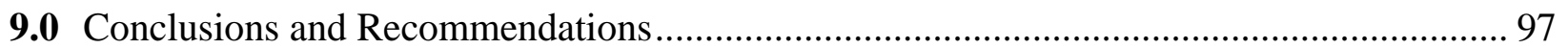

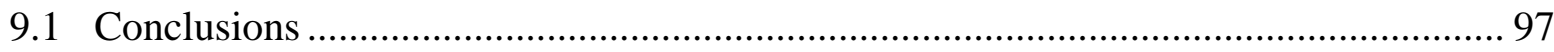

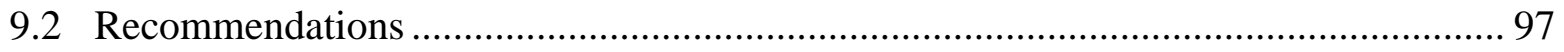

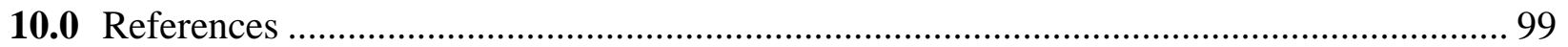

\section{Appendices}

A NTS Waste Disposal Record Summaries, 1961-2004 .................................................. A-1

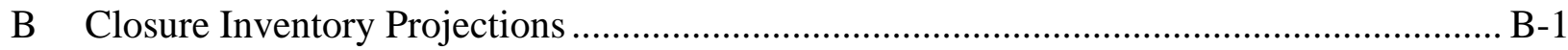

C Area 5 Sampling and Monitoring Locations ............................................................. C-1

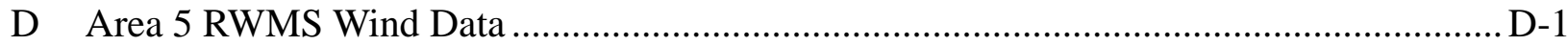

E Borehole Data and Well Details ............................................................................. E-1

F Groundwater Quality Data Summary ................................................................

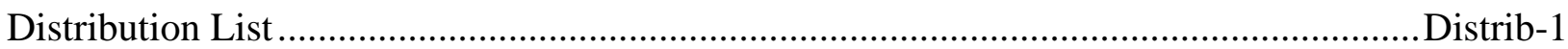




\section{Figures}

1-1. Location of the Area 5 Radioactive Waste Management Site,

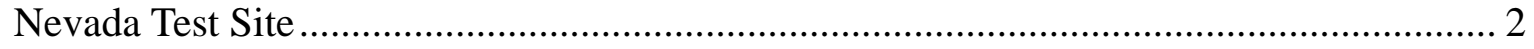

1-2. Hydrographic Basins ............................................................................................. 3

2-1. Layout of the Area 5 Radioactive Waste Management Site Showing Disposal Units and Waste Types ................................................................... 6

2-2. Location of GCD Boreholes within the 92-Acre Area of the Area 5 RWMS ................... 7

2.3. Closure Status of Area 5 RWMS Disposal Units, August 2005.................................... 8

3-1. Waste Container Emplacement in a Typical Pit at the Area 5 Radioactive Waste Management Site ......................................................................................... 16

3-2. Emplacement of Backfill Over Waste Containers....................................................... 16

5-1. General Geologic Map of Frenchman Flat and Vicinity ............................................. 26

5-2. Monitoring Stations at the Area 5 Radioactive Waste Management Site......................... 27

5-3. Historical Precipitation Record for Area Well 5B and Area 5 Radioactive Waste Management Site .................................................................... 28

5-4. 2004 Wind Rose Diagram for the Area 5 RWMS Meteorology Station ........................... 31

5-5. Nevada Test Site, Area 5 RWMS, Wind Rose for 1994 to 2004 .................................... 32

5-6. Nevada Test Site, Well 5B, Wind Rose for 1981 to 2004 .............................................. 32

5-7. Locations of Borings, Trenches and Wells in the Vicinity of the

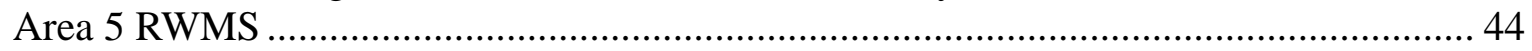

5-8. Soil Gas Tritium Concentrations at Each Sampling Depth

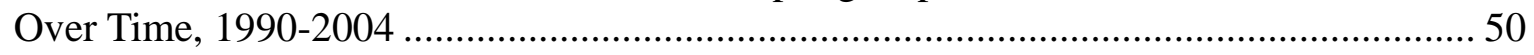

5-9. Locations of Neutron Probe Access Tubes................................................................... 53

5-10. Locations of the Area 5 RWMS Pilot Wells and Weighing

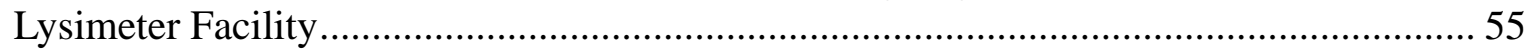

5-11. Soil Water Storage and Precipitation over Time, March 1994 through 2004 .................. 56

5-12. Cumulative Precipitation, Evapotranspiration, Evaporation, and Storage Change for Weighing Lysimeter in 2004............................................. 57

5-13. Monthly Precipitation, Evaporation, and Evapotranspiration Measured at Weighing Lysimeters in 2004 ............................................................. 57

5-14. Conceptual Model of Water Flow in the Unsaturated Zone in the Vicinity of the Area 5 Radioactive Waste Management Site ...................................... 59

5-15. Groundwater Basins and Regional Groundwater Flow Directions ................................ 61

5-17 Groundwater Elevation at the Area 5 RWMS 1993 through 2004................................... 65

5-18. 100-Year Flood Zone Delineation Map......................................................................... 75

6-1. Vadose Zone Hydrologic Conceptual Model of the Area 5 Radioactive Waste Management Site 


\section{Tables}

2-1. Area 5 RWMS 92-Acre Area Waste Unit Status...................................................... 9

3-1. Corresponding Waste Disposal Unit Names................................................................ 12

5-1. Annual Potential Evapotranspiration Compared to

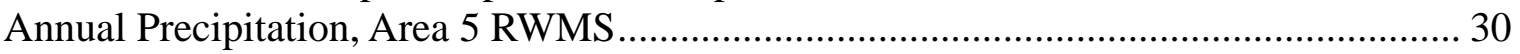

5-2. Hydrogeological Properties, Core Samples from Pilot Wells....................................... 47

5-3. March 22, 1993, through January 2 2005, Groundwater Elevation Flow ....................... 64

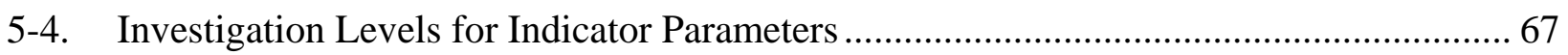

5-5. Operational Covers - Grain Size Distribution....................................................... 80

5-6. Operational Covers - Specific Gravity ................................................................... 81

5-7. Operational Covers - Maximum Achievable Compaction, Proctor Test ......................... 81

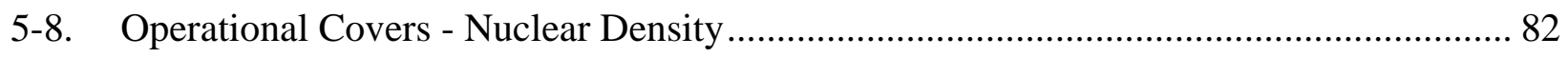

5-9. Operational Covers - Bulk Density, Compaction, and Permeability .............................. 83

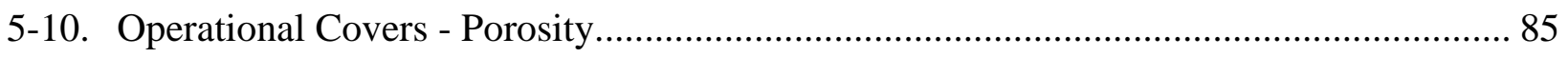

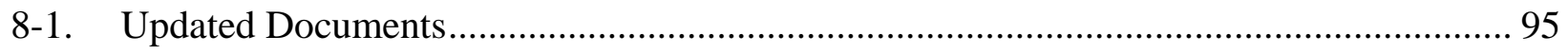


Characterization Report 92-Acre Area

Section: Table of Contents

Revision: 0

Date: June 2006

This page intentionally left blank 


\section{ACRONYMS AND ABBREVIATIONS}

ac

AES

AFM

ALARA

BN

BEIDMS

$\mathrm{C}$

$\mathrm{Ca}$

CA

CAU

CFR

${ }^{36} \mathrm{Cl}$

$\mathrm{cm}$

$\mathrm{cm}^{3}$

$\mathrm{cm} / \mathrm{sec}$

DAS

DCG

DoD

DOE

DOE/NV

DQO

DVRFS

EPA

FEMA

F

FR

FFACO

$\mathrm{ft}$

$\mathrm{ft}^{3}$

$\mathrm{ft} / \mathrm{yr}$

FY

gal acre

Alternative Evaluation Study

Alluvial Fan Methodology

As Low As Reasonably Achievable

Bechtel Nevada

Bechtel Environmental Integrated Data Management System

Celsius

Calcium

Composite Analysis

Corrective Action Unit

Code of Federal Regulations

chlorine-36

centimeter

cubic centimeter

centimeters per second

Disposal Authorization Statement

Derived Concentration Guide

Department of Defense

U.S. Department of Energy

U.S. Department of Energy/Nevada Operations Office

Data Quality Objectives

Death Valley Regional Flow System

U.S. Environmental Protection Agency

Federal Emergency Management Agency

Fahrenheit

Federal Regulations

Federal Facility Agreement and Consent Order

foot, feet

cubic feet

feet per year

fiscal year

gallon 


\begin{tabular}{|c|c|}
\hline $\mathrm{g} / \mathrm{cm}^{3}$ & grams per cubic centimeter \\
\hline GCD & Greater Confinement Disposal \\
\hline GCDT & Greater Confinement Disposal Test \\
\hline ha & hectare \\
\hline $\mathrm{HCO}_{3}$ & bicarbonate \\
\hline HDP & Heat Dissipation Probe \\
\hline ICMP & Integrated Closure and Monitoring Plan \\
\hline in. & inch, inches \\
\hline $\mathrm{K}$ & potassium \\
\hline $\mathrm{kg}$ & kilogram(s) \\
\hline $\mathrm{km}$ & kilometer(s) \\
\hline $\mathrm{km}^{2}$ & square kilometers \\
\hline Ksat & saturated hydraulic conductivity \\
\hline $\mathrm{L}$ & Liter \\
\hline $\mathrm{lb}$ & pound(s) \\
\hline $\mathrm{lbs} / \mathrm{ft}^{3}$ & pounds per cubic foot \\
\hline LCA & Lower Carbonate Aquifer \\
\hline LLMW & Low-Level Mixed Waste \\
\hline LLW & Low-Level Waste \\
\hline LWIS & Low-Level Waste Information System \\
\hline M & Manual \\
\hline $\mathrm{m}$ & meter(s) \\
\hline $\mathrm{m}^{3}$ & cubic meters \\
\hline $\mathrm{m}$ amsl & meters above mean sea level \\
\hline MDC & minimum detectable concentration \\
\hline mi & miles \\
\hline $\mathrm{mi}^{2}$ & square miles \\
\hline $\mathrm{mg} / \mathrm{L}$ & milligrams per liter \\
\hline $\mathrm{Mg}$ & magnesium \\
\hline mGy & milliGray \\
\hline $\mathrm{mm}$ & millimeter \\
\hline $\mathrm{mph}$ & miles per hour \\
\hline $\mathrm{mR} /$ day & milliroentgens per day \\
\hline mrem & milliroentgen equivalent man \\
\hline MTRU & Mixed Transuranic (waste) \\
\hline
\end{tabular}




\begin{tabular}{|c|c|}
\hline MWDU & Mixed Waste Disposal Unit \\
\hline $\mathrm{m} / \mathrm{yr}$ & meters per year \\
\hline$\mu g / L$ & micrograms per liter \\
\hline $\mathrm{Na}$ & sodium \\
\hline NAC & Nevada Administrative Code \\
\hline NDEP & Nevada Division of Environmental Protection \\
\hline NESHAP & National Emissions Standard for Hazardous Air Pollutants \\
\hline NNSA/NSO & National Nuclear Security Administration Nevada Site Office \\
\hline NTS & Nevada Test Site \\
\hline NTSWAC & Nevada Test Site Waste Acceptance Criteria \\
\hline $\mathrm{O}$ & Order (as in DOE Order) \\
\hline OI & Organization Instruction \\
\hline $\mathrm{OP}$ & Organization Procedure \\
\hline PA & Performance Assessment \\
\hline $\mathrm{pCi} / \mathrm{L}$ & picoCurie(s) per liter \\
\hline $\mathrm{pCi} / \mathrm{m}^{3}$ & picoCuries per cubic meter \\
\hline $\mathrm{pCi} / \mathrm{m}^{2} / \mathrm{s}$ & picoCurie(s) per square meter per second \\
\hline PET & Potential Evapotranspiration \\
\hline PPT & precipitation \\
\hline RCRA & Resource Conservation and Recovery Act \\
\hline REECO & Reynolds Electrical and Engineering Co, Inc. \\
\hline RREMP & Routine Radiological Environmental Monitoring Plan \\
\hline RSN & Raytheon Services Nevada \\
\hline RWM & Radioactive Waste Management \\
\hline RWMS & Radioactive Waste Management Site \\
\hline${ }^{90} \mathrm{Sr}$ & strontium-90 \\
\hline TDR & Time-Domain Reflectometry \\
\hline TEDE & Total Effective Dose Equivalent \\
\hline TFRG & TRU Federal Review Group \\
\hline TLD & thermoluminescent dosimeter \\
\hline TOC & total organic carbon \\
\hline TOX & total organic halogens \\
\hline TRU & Transuranic \\
\hline UGTA & Underground Test Area \\
\hline yr & year \\
\hline
\end{tabular}


Characterization Report 92-Acre Area Section: Acronyms and Abbreviations

Revision: 0

Date: June 2006

This page intentionally left blank 


\subsection{INTRODUCTION}

The U.S. Department of Energy (DOE) National Nuclear Security Administration Nevada Site Office (NNSA/NSO) manages two low-level Radioactive Waste Management Sites (RWMSs) at the Nevada Test Site (NTS). The Area 5 RWMS uses engineered shallow-land burial cells (trenches, pits, and borings) to dispose of packaged waste (Becker et al., 1998). This report summarizes characterization and monitoring work pertinent to the 92-Acre Area in the southeast part of the Area 5 RWMS. The southeast quadrant covers 37 hectare (ha) (92 acre [ac]), and is referred to as the "92-Acre Area." This information may be used to support development of closure plans. Closure of the 92-Acre Area disposal units is anticipated by 2011.

Although primarily a low-level waste (LLW) disposal facility, the 92-Acre Area includes 11 trenches and pits that may have received radioactive low-level mixed waste (LLMW) prior to the promulgation of the Resource Conservation and Recovery Act (RCRA). These were designated "Corrective Action Unit (CAU) 111: Retired Mixed Waste Pits” in the Federal Facility Agreement and Consent Order (FFACO). The 92-Acre Area also contains an active mixed-waste pit, two units which have received asbestiform LLW, and six disposal units which are known or suspected to have received some transuranic (TRU) waste. Portions of the 92-Acre Area have already been operationally closed with temporary earthen covers constructed over the waste. The closure strategy is to close the diverse unclassified waste and classified material disposal units in place, as six closure units, each consisting of one or more disposal units, under a single final cover. The final closure plans will meet the regulatory closure requirements for all the disposal unit waste types.

Over the past several decades, the vicinity of the RWMS has been intensely and thoroughly studied. The characterization and environmental monitoring data have been presented in numerous documents. The characteristics pertinent to potential contaminant transport have been well-defined and this information can be used to support closure plans for these facilities.

\subsection{Site Location}

The NTS is located in southern Nevada, 105 kilometers $(\mathrm{km})$ (65 miles [mi]) northwest of Las Vegas. The NTS is subdivided into administrative areas, with Area 5 on the eastern edge. The focus of this report is the southeast quadrant of the Area 5 RWMS (Figure 1-1).

The Area 5 RWMS is located in a topographically closed basin approximately $22 \mathrm{~km}$ (14 mi) north of Mercury, Nevada, in the north-central part of Frenchman Flat, and approximately $24 \mathrm{~km}$ (15 mi) south of the Area 3 RWMS, which is in south-central Yucca Flat. Figure 1-2 shows the RWMS facilities with respect to the approximate hydrographic basin boundaries. 
Characterization Report 92-Acre Area

Section: Introduction

Revision: 0

Date: June 2006

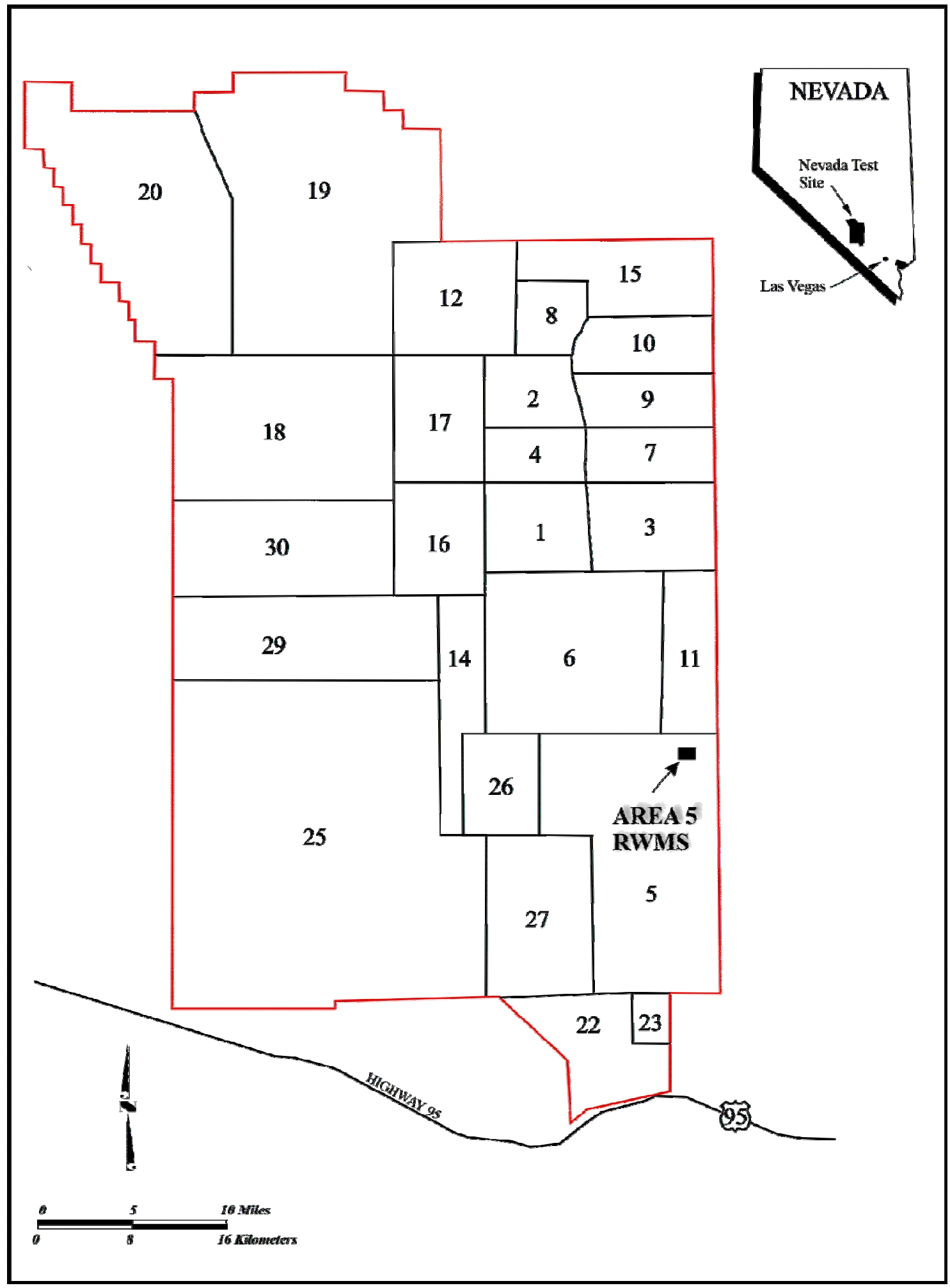

Figure 1-1. Location of the Area 5 Radioactive Waste Management Site, Nevada Test Site 
Characterization Report 92-Acre Area Section: Introduction

Revision: 0

Date: June 2006

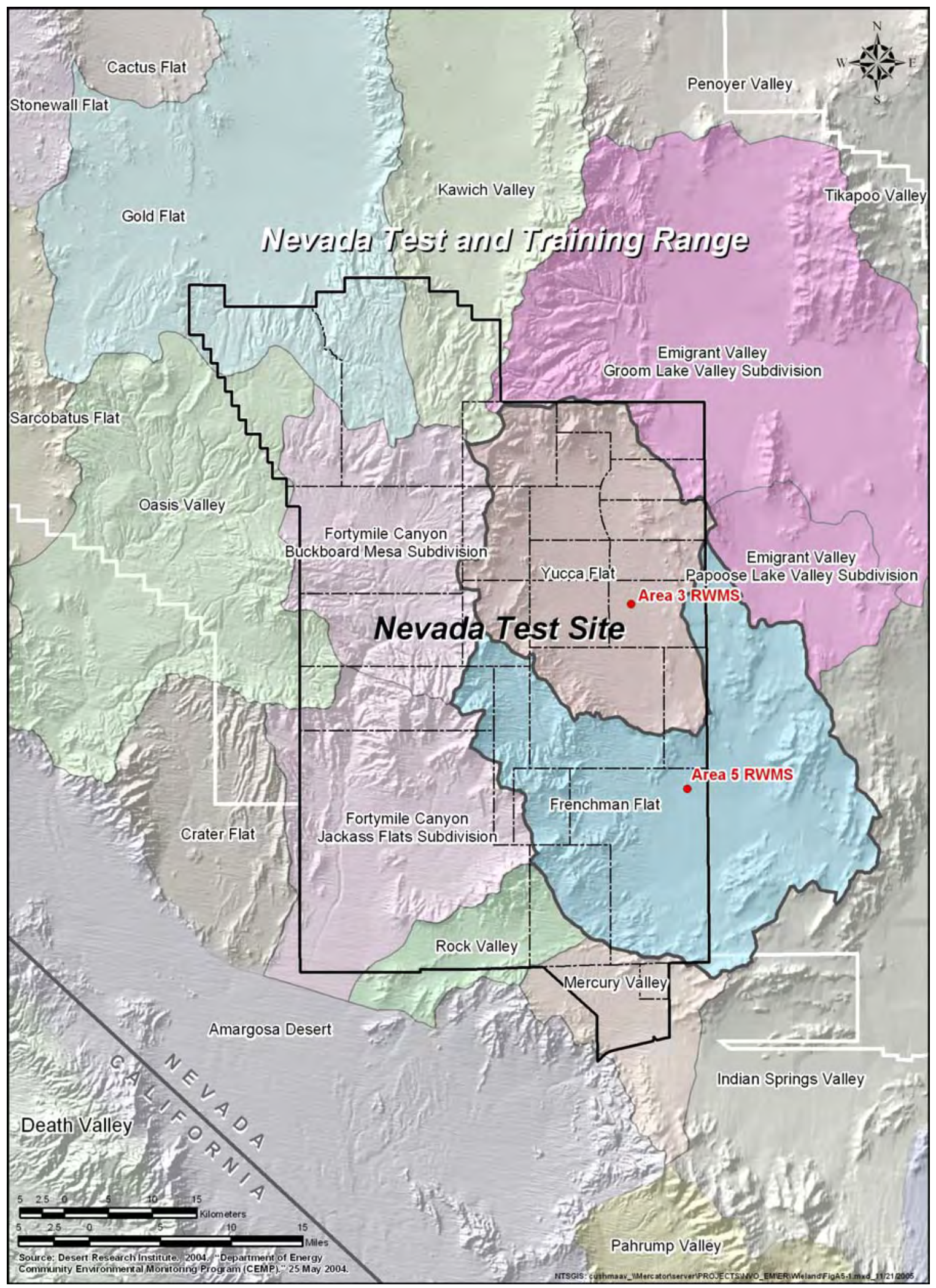

Figure 1-2. Hydrographic Basins 


\subsection{Report Objectives}

This report has been prepared by the NNSA/NSO to summarize characterization data pertinent to closure of the southeast portion of the Area 5 RWMS, known as the 92-Acre Area, including the CAU 111 retired mixed-waste pits and trenches. This report summarizes characterization and monitoring data required to support the development of a conceptual model and closure strategy.

\subsection{Report Contents}

The report summarizes relevant existing data regarding the 92-Acre Area of the Area 5 RWMS. The data are used to develop conceptual models of vadose zone and hydrogeological conditions of the site, general conclusions, and recommendations for a closure strategy. The report is organized as follows:

- 1.0 Introduction (location of site and purpose of document)

- 2.0 Facility Location, Layout, and Waste Unit Status

- 3.0 Waste Disposal Operations (history, general practices, and waste inventory)

- 4.0 Monitoring Programs

- 5.0 Site Characteristics (general summary of site area geography, meteorology, biota, geology, hydrology, soils, air quality, natural hazards/subsidence, and the physical characteristics of existing operational covers)

- 6.0 Conceptual Models and Assessments

- 7.0 Closure Planning (regulatory context, documents, and anticipated schedule)

- 8.0 Work in Progress (ongoing activities and reports due to be published soon, which will contribute to site characterization and closure planning)

- 9.0 Conclusions and Recommendations

- 10.0 References 


\subsection{LOCATION, LAYOUT, AND WASTE UNIT STATUS}

The Area 5 RWMS is approximately $22 \mathrm{~km}(14 \mathrm{mi})$ north of Mercury, Nevada, in the northern part of Frenchman Flat. The Area 5 RWMS covers 296 ha (732 ac) and is bounded by a buffer zone 305 meters (m) (1,000 feet [ft]) wide. The southeast and northeast quadrants of the RWMS are actively used for disposal or storage of wastes; although, many of the disposal units in the southeast quadrant are operationally closed or nearing capacity. The southeast quadrant covers 37 ha (92 ac), and is referred to as the "92-Acre Area." The northeast quadrant is being developed and is referred to as the "Expansion Area."

Figure 2-1 shows the disposal units of the Area 5 RWMS. The Area 5 RWMS currently consists of 45 disposal cells: 16 shallow excavated pits, 16 shallow excavated trenches, and 13 Greater Confinement Disposal (GCD) boreholes including the Greater Confinement Disposal Test (GCDT) facility (Figure 2-2). Nine of the shallow disposal pits and all 16 trenches and 13 boreholes are within the 92-Acre Area. Seven of the pits are in the new Expansion Area, north of the 92-Acre Area.

The disposal unit names are coded. Each shallow excavation is classified as either a "trench" (designated with the prefix “T”) or "pit" (designated with the prefix "P”), based on width. Generally pits are greater than $30 \mathrm{~m}$ [100 ft] wide and are large enough for a truck to turn around. The borehole designations have the prefix "GCD." The designations are suffixed with either a " $U$ " to indicate "unclassified" waste or " $C$ " for "classified" material. All material in the classified units is deemed to be classified material, not waste; although, in this report, the type of classified material is sometimes described by waste classes with similar properties.

Currently, 22 of the shallow cells are operationally closed with a cover of native soil approximately $2.4 \mathrm{~m}(8 \mathrm{ft})$ thick. All of the GCD boreholes are inactive. Six of the GCD boreholes and the GCDT are also operationally closed with thick soil covers. Figure 2-3 shows the operational status. For a detailed description of the facilities at the Area 5 RWMS, refer to the Performance Assessment (PA) (Shott et al., 1998). An addendum to the PA, with updated data and models, was published in January 2006.

The Area 5 RWMS 92-Acre Area has been divided into six closure units based on waste types and regulatory status:

- LLW Unit

- CAU 111 Unit

- Asbestiform Unit

- $\quad$ Pit 3 Mixed Waste Disposal Unit (MWDU)

- $\quad$ TRU GCD Borehole Unit

- $\quad$ TRU Trench Unit. 


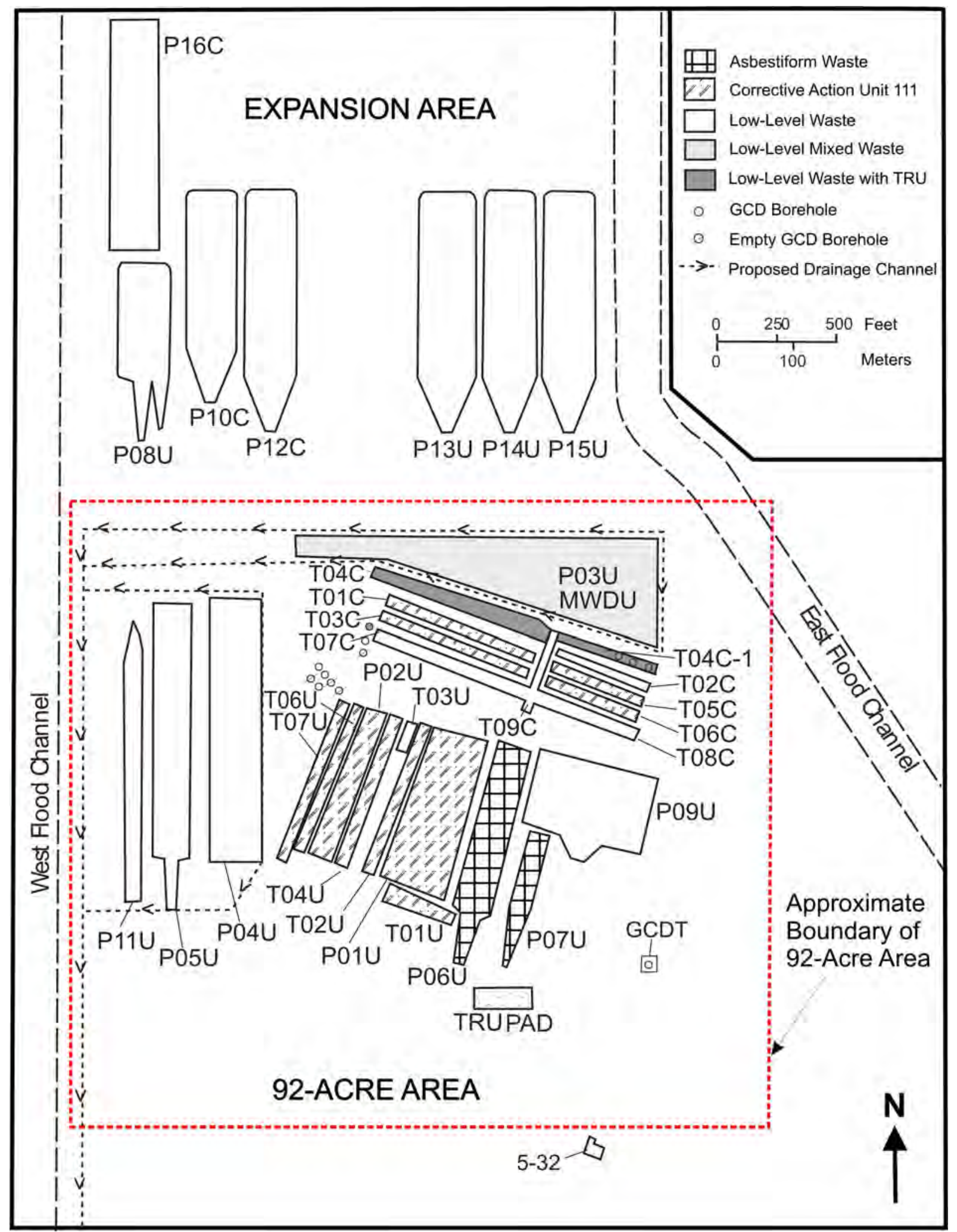

Figure 2-1. Layout of the Area 5 Radioactive Waste Management Site Showing Disposal Units and Waste Types 


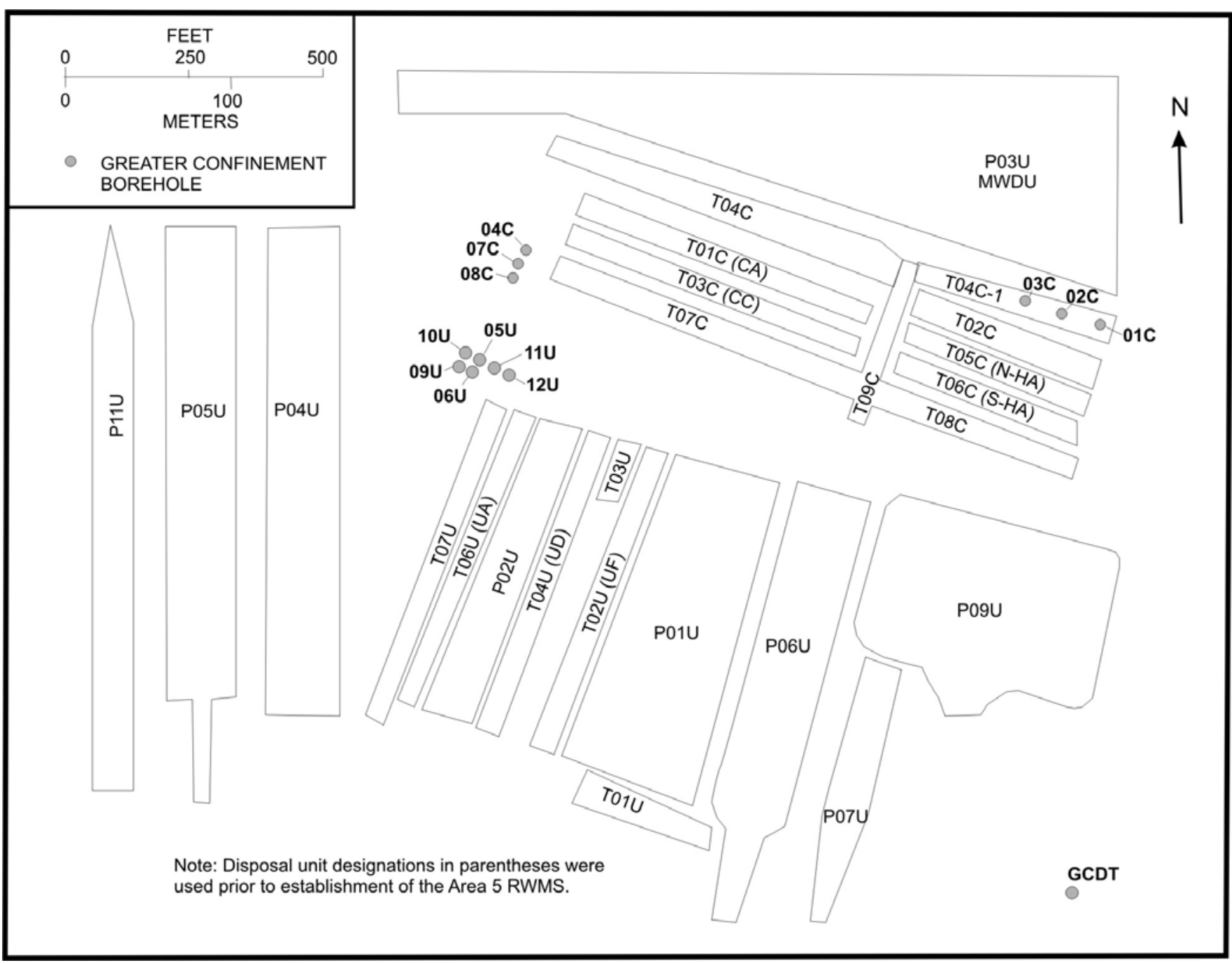

Figure 2-2. Location of GCD Boreholes within the 92-Acre Area of the Area 5 RWMS

Table 2-1 summarizes the type of waste, operational status, and principal closure regulations applicable to each closure unit. The CAU 111 closure unit, within the Area 5 Retired Mixed Waste Pits, is listed in Appendix II of the FFACO (FFACO, 1996), an agreement between DOE and the Nevada Division of Environmental Protection (NDEP), as a single corrective action site (CAS 05-21-01). Operational monitoring of the RWMS facility suggests there has been no migration of contaminants from the operating facility and little potential for post-closure migration of contaminants. Closure of the CAU 111 disposal unit will have to meet RCRA requirements. The site is listed in RCRA Part B Permit NEV HW009 (NDEP, 2000). 


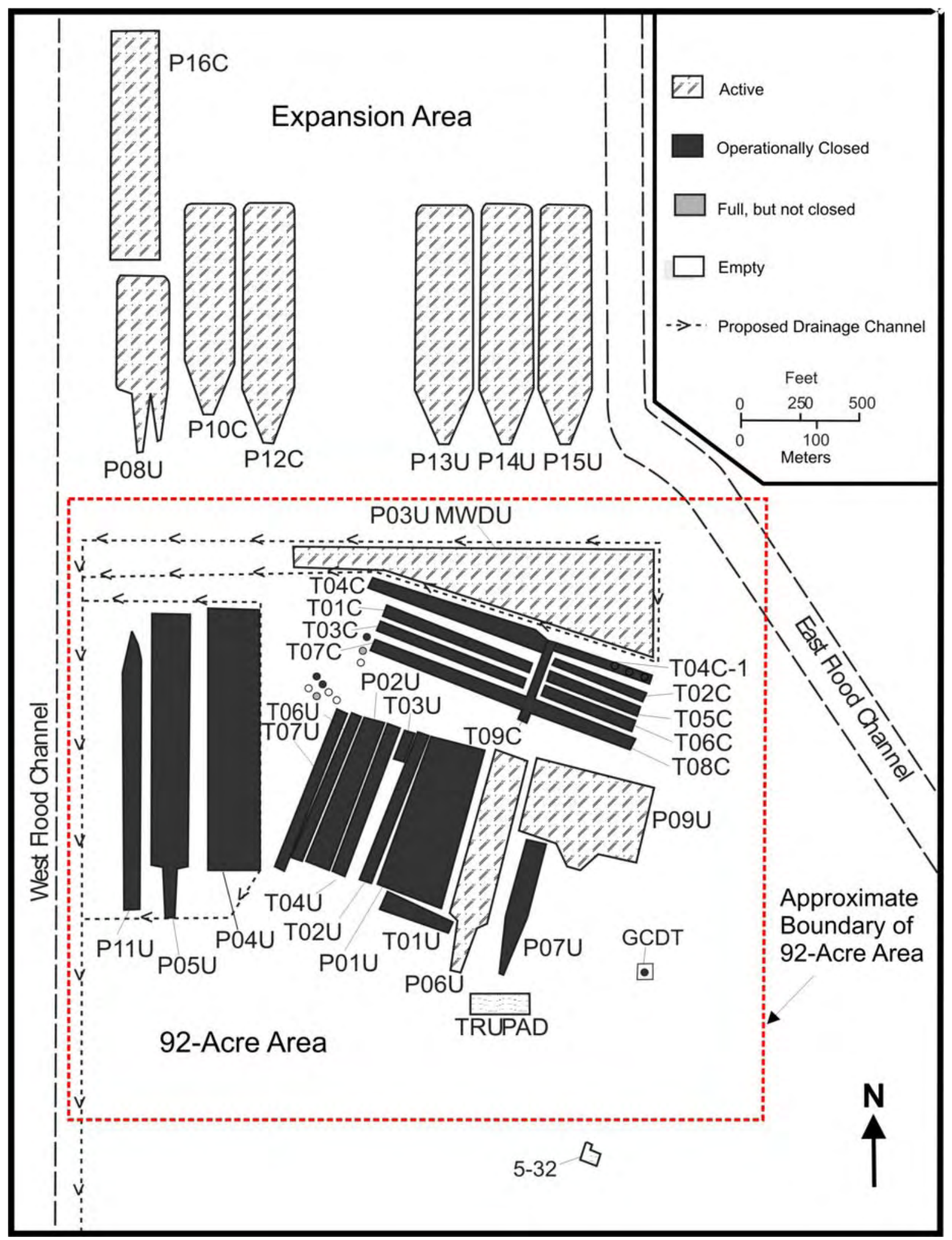

Figure 2.3. Closure Status of Area 5 RWMS Disposal Units, August 2005 
CAU 111 primarily includes those pits and trenches that are known or suspected to contain some LLMW, which were operating prior to when RCRA was originated, and which do not have any known TRU waste or TRU classified material. Trench T07U is included in CAU 111 because it was operated prior to the promulgation of RCRA; however, there is no evidence in the waste records that it ever received hazardous constituents. Figure 2-1 shows the CAU 111 disposal features with respect to the other disposal features within the 92-Acre Area of the Area 5 RWMS. CAU 111 includes waste and classified material disposal units which are all operationally closed: P01U, P02U, T01U, T02U, T04U, T06U, T07U, T01C, T03C, T05C, and T06C. CAU 111 is to be closed-in-place concurrently with other features within the Area 5 RWMS.

Units T04C and T04C-1 appear to have originally been a single trench known as T04C. When Trench T09C was excavated perpendicular to T04C in 1995, the north entrance to T09C bisected the T04C trench. The east side of T04C was eventually re-designated T04C-1. The boundaries of T04C-1 are poorly defined, but a past employee recalls the original T04C trench extending east to the facility fence line (Personal Communication, B. Ford, July 14, 2005). Three of the GCD boreholes (GCD-01C, GCD-02C, and GCD-03C) were drilled in the east end of the former T04C trench (now T04C-1) in 1984. Some mixed TRU material was disposed in these boreholes. For further information see Section 3.1, "History."

Table 2-1. Area 5 RWMS 92-Acre Area Waste Unit Status

\begin{tabular}{|c|c|c|c|c|}
\hline CLosure UNIT & WASTE UNIT & $\begin{array}{l}\text { Status OF Operation } \\
\text { (DEC 2005) }\end{array}$ & WASTE TYPE/ MATERIAL & $\begin{array}{l}\text { Principal Closure } \\
\text { Regulations }\end{array}$ \\
\hline \multirow{18}{*}{ LLW Unit } & P09U & Active & \multirow{18}{*}{ LLW } & \multirow{18}{*}{ DOE O 435.1} \\
\hline & T03U & Operationally Closed & & \\
\hline & T02C & Operationally Closed & & \\
\hline & T07C & Operationally Closed & & \\
\hline & T08C & Operationally Closed & & \\
\hline & T09C & Operationally Closed & & \\
\hline & GCDT & Operationally Closed & & \\
\hline & GCD-05U & Operationally Closed & & \\
\hline & GCD-06U & Open, full & & \\
\hline & GCD-07C & Open, full & & \\
\hline & GCD-08C & Open, empty & & \\
\hline & GCD-09U & Open, empty & & \\
\hline & GCD-10U & Operationally Closed & & \\
\hline & GCD-11U & Open, empty & & \\
\hline & GCD-12U & Open, empty & & \\
\hline & P04U & Operationally Closed & & \\
\hline & P05U & Operationally Closed & & \\
\hline & $\mathrm{P} 11 \mathrm{U}$ & Operationally Closed & & \\
\hline
\end{tabular}


Characterization Report 92-Acre Area

Section: Location, Layout, and Waste Unit Status

Revision: 0

Date: June 2006

Table 2-1. Area 5 RWMS 92-Acre Area Waste Unit Status (continued)

\begin{tabular}{|c|c|c|c|c|c|}
\hline \multicolumn{2}{|c|}{ CLOSURE UNIT } & WASTE UNIT & $\begin{array}{l}\text { STATUS OF OPERATION } \\
\text { (DEC 2005) }\end{array}$ & WASTE TYPE/ MATERIAL & $\begin{array}{l}\text { Principal Closure } \\
\text { REGULATIONS }\end{array}$ \\
\hline \multirow{11}{*}{\multicolumn{2}{|c|}{ CAU 111 Unit }} & P01U & Operationally Closed & \multirow{11}{*}{ LLMW } & \multirow{11}{*}{$\begin{array}{l}\text { FFACO, RCRA Part B } \\
\text { Permit \# NEV } \\
\text { HW009, CFR } 265.310\end{array}$} \\
\hline & & $\mathrm{P} 02 \mathrm{U}$ & Operationally Closed & & \\
\hline & & T01U & Operationally Closed & & \\
\hline & & T02U & Operationally Closed & & \\
\hline & & T04U & Operationally Closed & & \\
\hline & & T06U & Operationally Closed & & \\
\hline & & T07U & Operationally Closed & & \\
\hline & & T01C & Operationally Closed & & \\
\hline & & T03С & Operationally Closed & & \\
\hline & & T05C & Operationally Closed & & \\
\hline & & T06C & Operationally Closed & & \\
\hline \multirow{2}{*}{\multicolumn{2}{|c|}{ Asbestiform Unit }} & P06U & Active & \multirow{2}{*}{ Asbestiform/LLW } & \multirow{2}{*}{$\begin{array}{l}\text { NV Solid Waste } \\
\text { Disposal Site Permit } \\
\text { \#SW } 1300001\end{array}$} \\
\hline & & P07U & Operationally Closed & & \\
\hline \multicolumn{2}{|c|}{ Pit 3 MWDU } & P03U & Active & LLMW & $\begin{array}{l}\text { RCRA Part B Permit } \\
\text { \# NEV HW009 }\end{array}$ \\
\hline \multirow{5}{*}{\multicolumn{2}{|c|}{$\begin{array}{c}\text { TRU GCD Borehole } \\
\text { Unit }\end{array}$}} & GCD-01C & Operationally Closed & TRU, MTRU & \multirow{5}{*}{$\begin{array}{l}40 \text { CFR } 191 \\
\text { TFRG Criteria } \\
\text { CFR } 265.310\end{array}$} \\
\hline & & GCD-02C & Operationally Closed & TRU, MTRU & \\
\hline & & GCD-03C & Operationally Closed & TRU, MTRU & \\
\hline & & GCD-04C & Operationally Closed & $\begin{array}{l}\text { LLW, LLMW, TRU, } \\
\text { MTRU }\end{array}$ & \\
\hline & & T04C-1 & Operationally Closed & LLW & \\
\hline TRU Tren & ר Unit & T04C & Operationally Closed & $\begin{array}{c}\text { LLW, TRU, MTRU } \\
\text { (1.2 kilograms } \\
\text { inadvertently disposed } \\
\text { in 1986) }\end{array}$ & $\begin{array}{c}40 \text { CFR } 191 \\
\text { TFRG Criteria } \\
\text { Risk -informed } \\
\text { process (subject to } \\
\text { DOE approval of } \\
\text { National Academy of } \\
\text { Sciences } \\
\text { recommendations) } \\
\text { CFR 265.310 }\end{array}$ \\
\hline \multicolumn{6}{|l|}{ Note: } \\
\hline CFR & \multicolumn{5}{|c|}{ Eederal Regulations } \\
\hline DOE & \multicolumn{5}{|c|}{ United States Department of Energy } \\
\hline FFACO & \multicolumn{5}{|c|}{ Federal Facility Agreement and Consent Order } \\
\hline LLMW & \multicolumn{5}{|c|}{ Low-level mixed waste } \\
\hline LLW & \multicolumn{5}{|c|}{ Low-level waste } \\
\hline RCRA & \multicolumn{5}{|c|}{ Resource Conservation and Recovery Act } \\
\hline TFRG & \multicolumn{5}{|c|}{ TRU Federal Review Group } \\
\hline TRU & \multicolumn{5}{|c|}{ Transuranic } \\
\hline MTRU & \multicolumn{5}{|c|}{ Mixed transuranic } \\
\hline
\end{tabular}




\subsection{WASTE DISPOSAL OPERATIONS}

This Section summarizes the waste disposal operations at the Area 5 RWMS. The location, history of disposal, waste placement, waste container descriptions, and waste inventory are discussed briefly. For more detail, refer to the Integrated Closure and Monitoring Plan (ICMP) for the Area 3 and Area 5 RWMSs (Bechtel Nevada [BN], 2005a), the Area 5 RWMS PA (Shott et al., 1998), and the Addendum to the PA for the Area 5 RWMS (BN, 2006).

The Area 5 RWMS covers 2,936 ha (732 ac) and is bounded by a buffer zone $305 \mathrm{~m}$ (1,000 ft) wide. The southeast quadrant was developed first, and is known as the 92-Acre Area. Waste disposal began in the northeast quadrant in May 2002, in an area referred to as the Expansion Area (Personal Communication, Douglas Clark, September 15, 2005).

Disposed materials included LLW and material from on-site, DOE off-site, and other approved off-site generators; LLMW and classified material from on site; TRU classified material; MTRU classified material; and asbestiform waste. The 13 GCD boreholes were used for the disposal of high specific-activity LLW (waste similar to Greater-than Class C). Some of the boreholes contain TRU, MTRU, LLW, and LLMW classified materials.

The RWMS accepts packaged LLW and LLMW generated within Nevada, under the purview of NNSA/NSO, as well as asbestiform waste. A RCRA permit modification was approved November 21, 2005, which allows the P03U MWDU to operate for up to 5 years. The permit also allows disposal of LLMW for other government sites (Personal Communication, M. Dolenc, December 14, 2005).

Classified materials are not regulated as waste and are considered temporarily stored at the Area 5 RWMS. The classified material will be considered retrievable even after placement of the final cover.

\subsection{HISTORY}

Disposal of radioactive waste by burial in Area 5 started in January 1961, prior to the origination of federal radioactive waste management regulations and RCRA. Waste-profiling practices, analytical methods, and tracking practices have changed significantly since then. Few photographs have been found, especially from the Cold War years. Consequently, information on the earliest inventory and disposal practices is more general and less complete than in later years. Unclassified disposal records for classified trenches are limited. Temporary coverings known as "white elephants" have often been used to conceal disposition of classified material from satellite and aerial photography. Analytical profiling initially focused on radioactivity but, from process knowledge and general descriptions, it can be inferred that some of the older wastes are mixed waste. Inventory tracking and waste characterization are presented in Section 3.5. The historical development of the disposal features follows.

The original facility was called the Sugar Bunker Dump. Historic hard copy/paper records suggest Sugar Bunker Dump accepted waste for surface storage as early as January 1960, and began 
burying waste by January 1961 when Pit No. 1 (later designated as T01U) was opened. This appears to be the principal disposal feature until 1965, when records indicate trenches CC, UA, and Composite Analysis (CA) (later designated T03C, T06U, T01C) began receiving LLW and classified material. Trench UD (later designated T04U) received waste starting in 1970 and was the principal unclassified Area 5 disposal unit from 1970 through 1972. Trench UF (later designated T02U) opened by July 1972. Classified material trenches N-HA and S-HA (later designated T05C and T06C) were operating by 1974 and appeared to be mostly full by mid-1976. These eight shallow disposal trenches all received LLW/classified material and waste/classified material that contained hazardous constituents or suspected hazardous constituents. All eight trenches were operationally closed by 1978.

Trench T04C began receiving classified material in March 1969. In 1995, when Trench T09C was excavated perpendicular to the T04C trench, the east end of the trench was renamed T04C-1. For a brief time, the three attached trenches were used concurrently. The T04C and T04C-1 trenches were operationally closed in August 1995.

The DOE established the NTS Waste Management Program in 1978, and designated a 2,936-ha (732-ac) site, including the Sugar Bunker Dump, as the Area 5 RWMS. The names of the original Sugar Bunker disposal units changed. Table 3-1 shows the correlation of old designations to the current designations.

Table 3-1. Corresponding Waste Disposal Unit Names

\begin{tabular}{|c|c|}
\hline $\begin{array}{c}\text { SUGAR BUNKER } \\
\text { (source: DOE report NVO-193, 1978) }\end{array}$ & $\begin{array}{c}\text { AREA 5 RWMS } \\
\text { (source: Area 5 RWMS 2001 Atlas) }\end{array}$ \\
\hline \hline Pit No. 1 & T01U \\
\hline UF & T02U \\
\hline UD & T04U \\
\hline UA & TO6U \\
\hline CA & T01C \\
\hline CC & T03C \\
\hline N-HA & T05C \\
\hline S-HA & T06C \\
\hline RF\#1 & T07U \\
\hline
\end{tabular}

The DOE Nevada Operations Office (now the NSO) began promoting the Area 5 RWMS as a disposal site to other DOE facilities. Starting in 1978, the Area 5 RWMS began receiving LLW from offsite DOE generators (Personal Communication, M. Dolenc, July 12, 2005).

Trench RF\#1, later designated as trench T07U, was opened by 1978. Historic photos and waste disposal records show this trench received waste from Rocky Flats. There is no evidence in the disposal records of hazardous material being disposed of in T07U. 
Between 1978 and September 26, 1988 (when DOE Order [O] 5820.2A, "Radioactive Waste Management” [now replaced with DOE O 435.1] was promulgated), two pits and one more trench (P01U, P02U, and T07U) were filled and operationally closed.

In 1986, approximately 1.2 kilograms (kg) (2.6 pounds [lbs]) of TRU waste from Rocky Flats were inadvertently disposed in trench T04C. This trench is currently operationally closed.

In 1981, the GCDT borehole was equipped to evaluate the feasibility of disposing high specificactivity waste in alluvial soils at the NTS. The GCDT waste included layers of encapsulated sources of ${ }^{90} \mathrm{Sr},{ }^{137} \mathrm{Cs}$, and ${ }^{60} \mathrm{Co}$; ${ }^{90} \mathrm{Sr}$ in thermoelectric generators; and drums containing ${ }^{226} \mathrm{R}$, ${ }^{227} \mathrm{Ac}$, and ${ }^{3} \mathrm{H}$. Nine 36-m (120-ft) monitoring boreholes were drilled around the GCDT

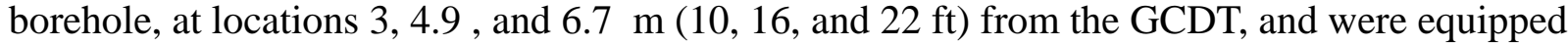
with instruments to monitor soil temperature, soil moisture, and migration of tracers or radionuclides. The GCDT project ran for over 7 years and provided information on potential for waste migration. The GCDT borehole was then operationally closed.

Based on the early results provided by the GCDT, 12 GCD boreholes were augered for operational use in 1984 (BN, 2002a). According to a site employee, three of the borings were drilled in the base of the east end of Trench T04C, later renamed T04C-1 (Personal Communication, B. Ford, July 14, 2005). The rest of the GCD boreholes appear to be drilled from ground surface, outside of the trenches.

The GCD boreholes are generally $3 \mathrm{~m}(10 \mathrm{ft})$ in diameter and $36 \mathrm{~m}(120 \mathrm{ft})$ deep and unlined, except for $3 \mathrm{~m}$ (10 ft) of corrugated metal pipe surface casing. Between 1984 and 1989, 8 of the 12 operational GCD boreholes were used to dispose of "special case” or "orphan" wastes. These are wastes and classified materials that did not meet acceptance criteria for other facilities (BN, 2002a). They have subsequently been classed as high specific-activity LLW, TRU, and MTRU. Materials stored in GCD 1, 2, 3, 4, and 7 are classified. Detailed inventories of waste and materials in the GCD boreholes are presented in Dickman (1989), Chu and Bernard (1998), and summarized in BN (2002a).

Although the GCDT and the Area 5 RWMS monitoring data suggested burial in these boreholes was safe and effective, disposal of waste and classified material in GCD was discontinued in 1989 (Cochran; Crowe, et al., 2001). NDEP determined the borings to be Class IV injection wells, which are prohibited by U.S. Environmental Protection Agency (EPA) regulations and Nevada Administrative Code (NAC). Six GCD boreholes have been filled with waste, to a depth of about $21 \mathrm{~m}$ (70 ft) below surface, and operationally closed with backfill consisting of native soil. Two boreholes have received waste and remain open (although inactive), and four boreholes are empty.

In 1993, EPA clarified that underground disposal of containerized radioactive waste in geologic repositories subject to the Part 191 standards does not constitute underground injection under the EPA's underground injection control program (Title 40 Code of Federal Regulations [CFR] Part 191: Environmental Radiation Protection Standards for the Management and Disposal of Spent Nuclear Fuel, High-Level and Transuranic Radioactive Wastes [58 Federal Register \{FR\} 66398-66416]). However, the GCD program has not been reinstated. 
Since the promulgation of federal radioactive waste management regulations in 1988, 14 pits and trenches and 2 GCD boreholes have been active. Eleven of these pits and trenches are now operationally closed.

Most of the waste disposed of at the NTS has been from Defense Programs and the Environmental Management Program. In February 2000, a Record of Decision for the management of LLW expanded the approved generators to include DOE-funded research laboratories. As of October 2005, 29 radioactive waste generators were using the NTS facilities for waste disposal. The NTS LLW disposal volume for FY 2003 was over 90,000 cubic meters $\left(\mathrm{m}^{3}\right)\left(3,000,000\right.$ cubic feet $\left.\left[\mathrm{ft}^{3}\right]\right)$ (Denton et al., 2004).

There are currently three active pits in the 92-Acre Area: P03U, P06U, and P09U. Pit 3 (P03U) is the only active MWDU. P06U and P09U contain LLW. Pit 6 (P06U) accepts asbestiform LLW and the bottom tier is used for disposal of thorium waste.

\subsection{Waste Acceptance Criteria}

For its radioactive waste disposal sites at the NTS, NNSA/NSO has established the Nevada Test Site Waste Acceptance Criteria (NTSWAC) (NNSA/NSO, 2005a). The NTSWAC provides the requirements, terms, and conditions under which the NTS will accept LLW and mixed waste for disposal. Mixed waste generated within the state of Nevada by NNSA/NSO activities is also accepted for disposal. The NTSWAC includes requirements for the characterization, waste form, packaging, and transfer of material and for the generator waste certification program. The Radioactive Waste Acceptance Program personnel review each waste generator's program and documentation for compliance with the NTSWAC. Upon arrival at the NTS, the waste shipments/containers are inspected to verify placards, manifests, marking and labeling, and container integrity (Becker et al., 2002).

NNSA/NSO policies regarding the storage and disposal of radioactive waste are designed to achieve these goals:

- Ensure safe and compliant storage and disposal of radioactive waste.

- Be consistent with the current revision of all applicable federal, state, and local regulations.

- $\quad$ Protect the environment, personnel, and public from chemical and radiological hazards according to Title 40 CFR, RCRA; Title 10 CFR 835, “Occupational Radiation Protection”; DOE O 435.1, "Radioactive Waste Management”; and state of Nevada and applicable U.S. Department of Transportation regulations.

- Ensure that present and future radiation exposures are kept as low as reasonably achievable (ALARA) and do not exceed the radiation protection standards established in Title 10 CFR 835.

- Ensure that Quality Assurance programs are established and implemented to fulfill the requirements of DOE O 435.1; Title 10 CFR 830.122, “Quality Assurance”; and DOE O 414.1A, "Quality Assurance.” 
Detailed waste criteria requirements have been established for acceptance of transuranics, radionuclides, polychlorinated biphenyls, explosives, pyrophorics, asbestiform LLW, sealed sources, radioactive animal carcasses, low-level beryllium waste, and classified materials/waste. There are also requirements for minimization of free liquids, immobilization of particulates and gases, chemical and structural stability, chemical compatibility, and the use of chelating agents.

Commercial Greater-Than Class C wastes (as defined by Title 10 CFR 61.55) generated by the U.S. Nuclear Regulatory Commission licensees and etiological agents, are not accepted at the NTS.

Treatment, stabilization, and packaging requirements address specific hazards. Facility waste packaging acceptance criteria fulfill all applicable DOE Orders and federal requirements. Package requirements include design, nuclear safety, radiation levels, activity limits, nuclear heating, strength, shielding, and sealing. For further information on waste acceptance criteria, see Nevada Test Site Waste Acceptance Criteria-Revision 6 (NNSA/NSO, 2005a).

\subsection{Waste Placement}

Waste is transported to the Area 5 RWMS on trucks. On arrival, manifests are checked and the trucks are inspected, both visually and with instrumentation, to ensure there is no leakage of contaminated materials from the containers. After the vehicles are cleared, the containers are off-loaded and placed in the appropriate active pit or trench (Figure 3-1), depending on waste type and classification. Unloaded trucks are released only after they have been surveyed for contamination and found to be clean.

Pits and trenches range in depth from 4.6 to $15 \mathrm{~m}$ (15 to $48 \mathrm{ft}$ ). Disposal consists of placing waste in various sealed containers in the unlined pits and trenches. As rows of containers reach approximately $1.2 \mathrm{~m}(4 \mathrm{ft})$ below original grade, native alluvium is pushed over the containers in a single lift, approximately $2.4 \mathrm{~m}$ (8 ft) thick (Figure 3-2). The newest active units are typically 180 to $210 \mathrm{~m}$ (600 to $700 \mathrm{ft}$ ) long, 12 to $18 \mathrm{~m}$ (40 to $60 \mathrm{ft}$ ) wide, and 6 to $9 \mathrm{~m}$ (20 to $30 \mathrm{ft}$ ) deep.

Three "unclassified" pits (P03U, P06U, and P09U) are currently open in the 92-Acre Area for receipt of waste. Pit P03U is designated for disposal of LLMW, under RCRA interim status. Pit P06U was deepened for disposal of thorium waste.

The 13 GCD boreholes (including the GCDT) have not received waste since 1989. The GCD units are 3-m- (10-ft)-diameter vertical boreholes, $36 \mathrm{~m}(120 \mathrm{ft})$ deep. The boreholes are cased from the surface to a depth of $3 \mathrm{~m}(10 \mathrm{ft})$. Waste packages were placed in the bottoms of six of the GCD boreholes and the GCDT borehole up to a depth of approximately $21 \mathrm{~m}(70 \mathrm{ft})$ below land surface, and then backfilled with native soil. Two others received waste but have not been operationally closed, and four are empty.

For a detailed description of the facilities at the Area 5 RWMS, refer to the PA (Shott et al., 1998). An addendum to the PA is due to be published in FY 2006. For further descriptions of pits, trenches, and GCD boreholes, refer to Cochran et al. (2001b). 
Characterization Report 92-Acre Area Section: Waste Disposal Operations

Revision: 0

Date: June 2006

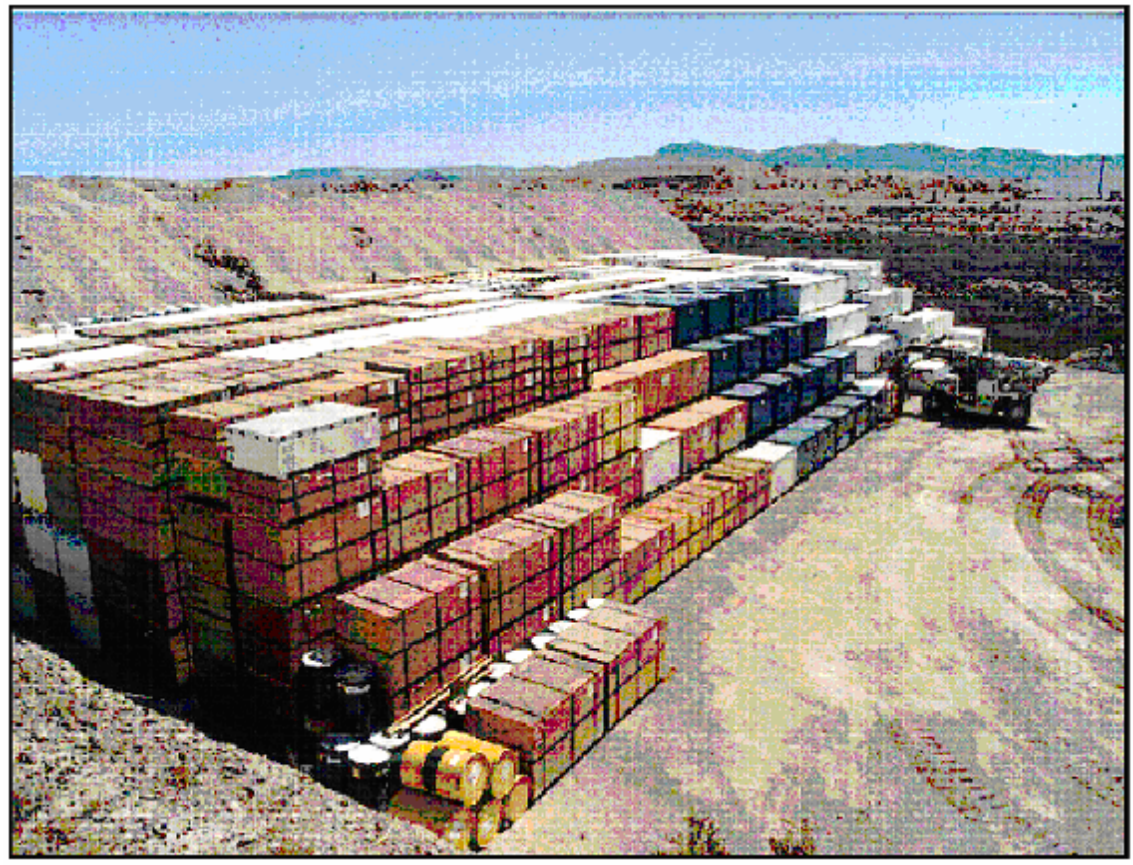

Figure 3-1. Waste Container Emplacement in a Typical Pit at the Area 5 Radioactive Waste Management Site

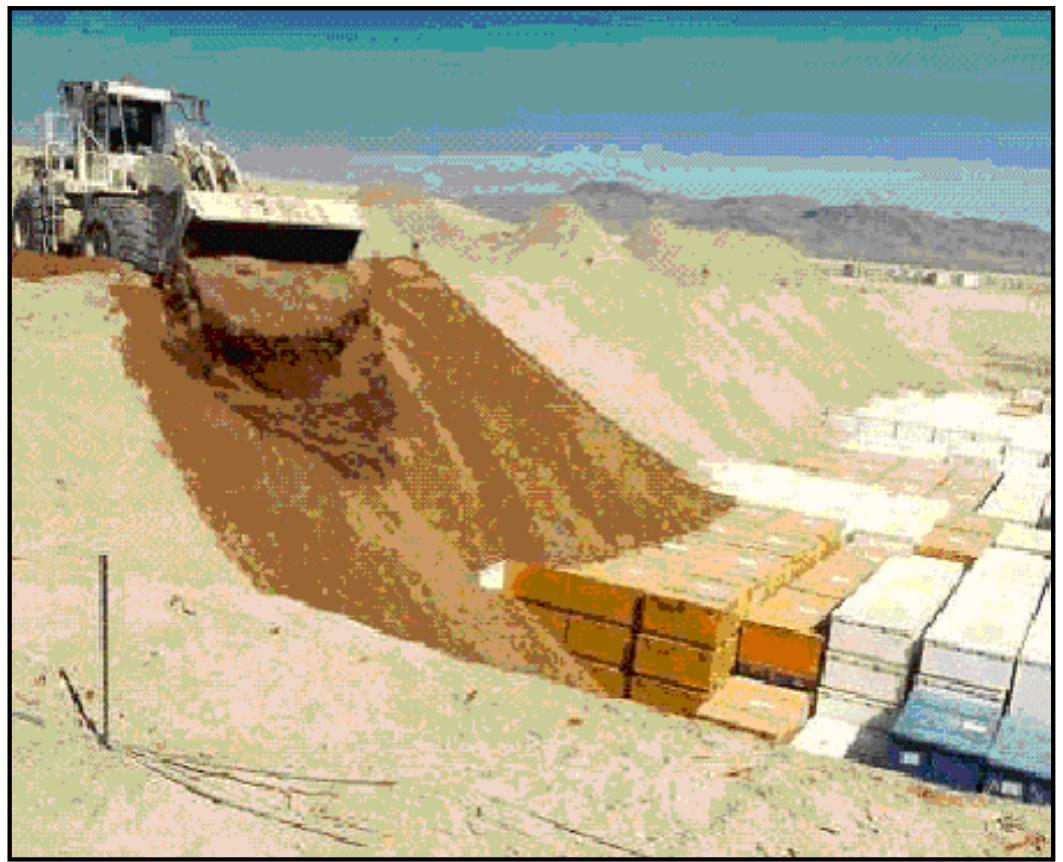

Figure 3-2. Emplacement of Backfill Over Waste Containers 


\subsection{WASte Containers}

The following description of waste containers that have been buried at the Area 5 RWMS was excerpted from the ICMP (BN, 2005a).

Containers disposed at the Area 5 RWMS are categorized as boxes, drums, or nonstandard. Cardboard, octagonal "tri-wall" boxes were commonly used prior to the mid-1980s. These cardboard boxes were 0.6 or $1.2 \mathrm{~m} \mathrm{(2} \mathrm{or} 4 \mathrm{ft}$ ) high and banded to wooden pallets with steel strapping. Waste was contained in plastic bags inside the cardboard boxes. These boxes were stacked as close to each other as the underlying pallet allowed and were susceptible to crushing if stacked too high.

Plywood boxes came into wide use thereafter, and range in size from $0.6 \mathrm{~m}(2 \mathrm{ft}) \mathrm{high}$, $1.2 \mathrm{~m} \mathrm{(4ft)} \mathrm{wide,} \mathrm{and} 2.1 \mathrm{~m} \mathrm{(7ft)} \mathrm{long,} \mathrm{to} 1.2 \mathrm{~m} \mathrm{(4} \mathrm{ft)} \mathrm{high,} 1.2 \mathrm{~m}(4 \mathrm{ft}$ ) wide, and $2.1 \mathrm{~m}$ (7ft) long. Runners are typically attached to the bottom of the boxes to facilitate handling with a forklift. More waste was received in steel boxes in the 1990s. The steel boxes come in standard sizes similar to those of plywood boxes, and steel runners or slots for handling with a forklift are typically part of the box design. Both the plywood and steel boxes are stacked as close to each other as practicable; typically, several inches (in) separate adjacent boxes.

Waste has also been disposed in steel drums of various sizes at the Area 5 RWMS. Standard 209-L (55-gallon [gal]) drums and 315-L (83-gal) overpack drums are common; less commonly used are six-drum overpack containers. Drums are stacked either vertically on pallets, horizontally in a square array, or horizontally in a nested array.

Containers other than standard-sized boxes and drums are considered nonstandard. Many nonstandard containers have been disposed at the Area 5 RWMS, including containers of unusual shapes or nonstandard-sized boxes or drums. Nonstandard containers are typically stacked to make best use of available pit volume.

\subsection{WASTE INVENTORY}

Wastes have been accepted at Area 5 of the NTS since January 1960, and placed in disposal cells since January 1961. The Low-Level Waste Inventory System User's Guide (BN, March 2005) provides detailed information on the structure and history of LLW and LLMW tracking systems at the NTS, including field codes and limitations. The completeness, quality, and level of detail of inventory records have changed over time. A brief summary of the evolution of inventory tracking follows.

The oldest records for the original Sugar Bunker Dump generally show load origin, a brief description of the material and containers, estimated radioactivity, date of disposal, and the disposal location (Area 3 or Area 5 RWMS). When necessary, a specific trench or pit can be inferred from burial date and history of the development of the disposal features. 
The original paper records were scanned into a digital format, then archived. The quality of some of these scanned images is poor and some of the data are difficult to read. There is also uncertainty as to the completeness of the scanned records (Personal Communication, M. Dolenc, July 21, 2005).

The Radioactive Waste Management (RWM) System was developed in 1988 to comply with DOE O 5820.2A. The RWM System tabulated basic information on a per-shipment basis, for waste received from August 13, 1974 through 1992. A container tracking system was also developed to store older data through FY 1992. The RWM System had design flaws, typical in early databases and early programming capabilities, which resulted in inconsistent entries, incomplete records, and the creation of orphan records due to poor interrelationships between the master tables and detail tables. Users of the system could modify, delete, and add data in sub-tables without changing, deleting, or adding records to the master table. An FY 2005 review of historical data attempted to correlate orphan nuclide and container data with generator shipments.

After September 30, 1992, the Low-Level Waste Information System (LWIS) Oracle application was implemented. Data in this database are stored in a single record, indexed by package. The level of characterization detail and burial location detail also improved. Burial location is provided based on an alphanumeric grid. The tier and location within the cell were recorded. The Oracle relational database structure of the LWIS prevents some of the quality and orphan data problems that plagued the RWM System. The web applications used by generators and waste operations personnel to input data also have built-in validation features that help reduce errors in the database. Bar-coding and scanning systems were implemented to facilitate package tracking.

In May 1997, the NTSWAC system, an enhancement to LWIS, was implemented. The improved waste-tracking system accepts multiple waste profiles, includes more detailed information on waste form and treatment, and is the system currently in use.

The Waste Management Infobank System combines data from source databases, intranet, and internet sites needed to support the Waste Management Program.

To document and improve the accuracy of the historic waste inventory for 1961 through 1978 and make the scattered information more usable, several historic tracking systems including paper records and previously scanned records were reviewed and crosschecked. Bechtel Nevada then incorporated the waste disposal data into one searchable spreadsheet. Chemical hazards were not routinely profiled before landfill regulations and RCRA were implemented. The presence of hazardous constituents and suspected hazardous constituents, and consequently the classification of some waste in these trenches as being potential LLMW, was inferred from general waste descriptions, historic photographs, and other sources. The early RWM System database covering waste disposal from the mid 1970s through 1992 was also checked and crosschecked with other documentation to attempt to verify the locations, volumes, and characteristics of the wastes disposed. A report documenting these record-review efforts is expected to be published in FY 2006. 
Appendix A contains preliminary information on waste and material buried at the Area 5 RWMS facilities from 1961 through December 2004. These data are from three sources: scanned paper records, the old RWM System database, and the revised LWIS database, with slightly overlapping periods of record. These data are provisional pending completion of an internal management review. These waste tracking systems primarily address waste disposal at the unclassified trenches, pits, and boreholes. The waste tracking systems have no data regarding classified material deposited at some of the classified disposal cells, and very limited data at other classified disposal cells.

Waste disposal records for the most of the GCD boreholes are also included in Appendix A. The report Evaluation of Regulations and Issues Associated with Final Closure of the Greater Confinement Disposal Boreholes (BN, 2002a) includes a detailed summary of the sources, types, volumes, packaging, and activities of waste deposited in the GCD boreholes. Much of the data was presented previously in the Waste Inventory and Preliminary Source Term Model for the Greater Confinement Disposal Site at the Nevada Test Site (Chu and Bernard, 1991). Waste and classified materials disposed in the GCD boreholes include radioactive waste and classified material that did not meet the criteria for the disposal of high-level waste, TRU waste, or LLW (Chu and Bernard, 1991). Although the PA (Cochran, Beyeler, et al., 2001) demonstrated compliance with EPA Title 40 CFR 191, disposal of waste at the GCD boreholes was discontinued in 1989 because NDEP deemed the disposal as underground injection.

Waste accounting practices have improved significantly since 1960 . The volume of waste deposited at each of the oldest disposal areas cannot be accurately estimated due to the quality and incompleteness of historical records, and the potential for double counting for truck loads split among multiple disposal sites. The estimates of waste volumes presented in Appendix A are most accurate for the newest waste disposal units and the unclassified units.

\subsection{FUTURE INVENTORY}

The 92-Acre Area of the Area 5 RWMS is expected to close by 2011, and the Expansion Area by 2021. The planned closure dates have changed slightly over time. The Area 5 RWMS PA estimated the inventory and approximate amounts of radionuclides anticipated to be disposed through 2028 in shallow pits and trenches at the entire Area 5 RWMS (Shott et al., 1998). Under DOE Order 435.1 Performance Objectives the PA is limited to waste disposed from September 26, 1988 to closure.

An updated PA is expected to be published in FY 2006. The updated report will include the revised estimated amounts of radionuclides in the Area 5 RWMS at closure, based on a longer history of complete records, and the latest information on expected generator activity. Hard copy/paper, scanned, and electronic records are being reviewed and cross-checked. The updated PA is expected to have an improved projection of the future radionuclide inventory at closure.

Table 3.7 of the PA (Shott et al., 1998) shows estimated activities of radionuclides and estimated mean activity concentrations for radionuclides in wastes disposed by shallow land burial at the Area 5 RWMS from FY 1989 to FY 2028. Table 3.8 of the PA shows preliminary estimates of 
the thorium waste that could be disposed in the lowest tier of Pit 6 (P06U) by 2028. These estimates are part of the assumptions that have been used as the basis of performance modeling.

Appendix B contains a preliminary revised projection of future inventories for the entire Area 5 RWMS including both the 92-Acre Area and the Expansion Area. The FY 2004 Area 5 RWMS Closure Inventory Estimate shows the approximate projected total activity of each nuclide in storage on September 31, 2028, for six inventory subsets. Of these inventory subsets, the 92-Acre Area would include the pre-1988 shallow land burial inventory, the lower cell of Pit 6 inventory, the pre-1988 GCD inventory, the post-1988 GCD inventory, and part of the post-1988 shallow-land burial inventory. The Expansion Area would include some of the post-1988 shallow-land burial inventory and the Pit 13 inventory. The inventory projection is based on the generators' projected future waste volumes and the average concentrations found in random samples of waste disposed in past years (Personal Communication, Gregory Shott, September 7, 2005). These closure inventory estimates are likely to change significantly through time as generators, programs, technology, and the availability of LLW disposal sites change. 


\subsection{MONITORING PROGRAMS}

The Waste Management monitoring program for the Area 5 RWMS is summarized in 4.0. Details of the RWMS monitoring program can be found in the RWMS ICMP (BN, 2005a). Monitoring programs include radiation exposure, air, groundwater, meteorology, vadose zone, subsidence, and biota.

\subsection{INTRODUCTION}

Environmental monitoring data, subsidence monitoring data, and meteorological monitoring data are routinely collected at and around the Area 3 and Area 5 RWMSs at the NTS. Monitoring at the Area 5 RWMS is required under a variety of regulatory drivers, including federal regulations and DOE Orders. Monitoring data are used to: demonstrate compliance, to evaluate landfill cover performance, to provide data for water and contaminant transport models, and to provide early warning of the need for any mitigative actions.

The programs are addressed in the ICMP (BN, 2005a) for monitoring direct radiation fields, air, vadose zone, biota, groundwater, meteorology, and subsidence during the operational closure period (current), and final closure/active institutional control periods. Monitoring data quality objectives (DQOs) are defined in the NTS Routine Radiological Environmental Monitoring Plan (RREMP) (BN, 2003a). The monitoring program is reviewed periodically to determine which data should be routinely collected and which are no longer required to meet regulatory and program needs.

The ICMP (BN, 2005a) describes the program for monitoring direct radiation, air, vadose zone, biota, groundwater, meteorology, and subsidence at the Area 3 and 5 RWMSs during the operational closure period (current), and final closure/active institutional control periods.

At present, direct radiation is continuously monitored at 10 locations at the Area 5 RWMS. Air monitoring for radionuclides, other than radon, is conducted at several locations at the RWMS using air samplers, whereas radon is passively monitored at six locations at the RWMS and at several background locations. Radon flux (through waste covers) is monitored annually at various locations at each RWMS and at background locations. Vadose-zone monitoring for soilwater content and soil-water potential is conducted continuously in waste covers, beneath waste units, and at lysimeter facilities. Surface water runoff is monitored at flumes. Tritium in soil-gas moisture is monitored at least annually in a deep borehole at the Area 5 RWMS (GCD-05U), which contains a large tritium source. Biota are monitored periodically for tritium. Groundwater from the uppermost aquifer is sampled semiannually. Water samples collected from three wells surrounding the Area 5 RWMS are analyzed for radioactive and nonradioactive constituents. Groundwater elevation is measured more frequently. Meteorological parameters are monitored continuously at the Area 5 RWMS. Waste cover subsidence is checked monthly.

Results of most of the monitoring programs are reported at various levels of detail in periodic reports including the NTS Environmental Report (e.g., BN, 2004a); the National Emission Standards for Hazardous Air Pollutants (e.g., National Emissions Standard for Hazardous Air 
Pollutants [NESHAP]) (BN, 2002b) report; the annual Groundwater Monitoring Report (e.g., BN, 2004b); and the NTS Waste Management Monitoring Report (e.g., BN, 2005c).

Appendix C contains a list of sampling and monitoring locations within Area 5 extracted from the Bechtel Environmental Integrated Data Management System (BEIDMS). This data set includes location information for borings and wells included in the NTS Redbook database.

\subsection{Monitoring During Operational Closure}

This Section is primarily extracted from Chapter 8.0 of the Characterization Report, Operational Soil Covers for the Area 5 Radioactive Waste Management Site at the Nevada Test Site (BN, 2005d). Monitoring during operational closure includes environmental monitoring of direct radiation, air, vadose zone, biota, and groundwater; subsidence monitoring of operational waste covers; and meterological monitoring to support water balance evaluations.

Activities and systems used to support water balance evaluations include:

- Meteorological monitoring to measure precipitation and to calculate potential evapotranspiration (PET).

- Lysimeters (weighing and drainage) to measure infiltration, soil water redistribution, bare-soil evaporation, evapotranspiration, and deep drainage.

- Automated vadose zone monitoring systems with time-domain reflectometry (TDR) probes, and heat dissipation probes (HDPs) to measure soil water content and soil water potential over a large spatial area.

- Surface water runoff monitoring at flumes and at the floor of a nuclear subsidence crater.

- Soil-gas sampling for tritium to confirm PA assumptions and transport coefficients.

Combining a variety of moisture measurements provides an accurate estimate of the RWMS water balance, including any drainage through the RWMS waste covers and potential recharge. These data and other work (Tyler et al., 1996) indicate that there is essentially no recharge to the groundwater under current conditions at the RWMSs. Precipitation is effectively returned to the atmosphere by plant transpiration and soil evaporation.

The RREMP (BN, 2003a) includes a technical design process for development of a detailed Quality Assurance, Analysis, and Sampling Plan for vadose-zone monitoring at the RWMS and guidance for action levels and corrective actions. It is styled after the EPA DQO process (EPA, 1994). The current vadose-zone monitoring program is designed on the basis of a strong understanding of the vadose-zone system through extensive vadose-zone characterization studies (Blout et al., 1995; BN 2005e; Reynolds Electrical \& Engineering Co., Inc. [REECo], 1993a, b; Shott et al., 1998, 1995; and Tyler et al., 1996) and modeling studies (Crowe, Hansen, et al., 1998; and Levitt et al., 1999). In addition, the vadose-zone monitoring program is partially designed based on the results of an Alternative Evaluation Study (AES) on vadose-zone monitoring (BN, 1998a) using an organized team approach, and successful vadose-zone monitoring field experience. Annual vadose-zone monitoring data are reported in an annual monitoring report (e.g., BN 2005c). Details of the RWMS vadose-zone monitoring activities can 
be found in the RWMS vadose-zone monitoring BN Organizational Instructions (OI) and BN Organization Procedures (OP), including OI-2154.111, Instructions for Datalogger Monitoring Stations; and OP-2154.113, Soil Gas Sampling at GCD-05U.

Meteorological monitoring data are reported in annual reports such as the Waste Management Monitoring Reports (e.g., BN, 2004a) and the NTS Environmental Report (e.g., BN, 2004). Details of the RWMS meteorology monitoring activities can be found in BN OI-2154.111, Instructions for Datalogger Monitoring Stations.

Monitoring results which contribute to characterization of the Area 5 RWMS are included in Chapter 5.0, "Site Characteristics."

\subsection{Monitoring During Final Closure And Active Institutional CONTROL}

Monitoring activities during the final closure and active institutional control periods of the RWMSs are expected to be reduced and limited to:

- Air monitoring for radon-222 and atmospheric tritium,

- Tritium monitoring of moisture in soil gas at GCD-05U,

- Vadose-zone monitoring of waste covers, waste disposal unit floors, and lysimeter facilities,

- Groundwater monitoring,

- Biota monitoring for tritium, and

- Subsidence monitoring.

Groundwater monitoring for compliance with Title 40 CFR 264 and 265 had been discontinued when a groundwater monitoring exemption was requested from, and approved by, NDEP. However, groundwater monitoring may continue at the Area 5 RWMS pilot wells under the RREMP program. 
Characterization Report 92-Acre Area

Section: Monitoring Programs

Revision: 0

Date: June 2006

This page intentionally left blank 


\subsection{SITE CHARACTERISTICS}

\subsection{Geography}

The Area 5 RWMS is within the boundary of the NTS, a remote federally controlled facility used for nuclear and nonnuclear testing and training. The NTS is bounded to the north, east, and west by restricted areas controlled by the U.S. Air Force: the Nevada Test and Training Range including the Tonopah Test Range. These contiguous federal reserves encompass about 14,200 square kilometers $\left(\mathrm{km}^{2}\right)\left(5,483\right.$ square miles $\left.\left[\mathrm{mi}^{2}\right]\right)$ of land.

The Area 5 RWMS is located about $130 \mathrm{~km}$ (81 mi) northwest of Las Vegas, Nevada (NV), the nearest major city. The closest public population center is Indian Springs, about $42 \mathrm{~km} \mathrm{(26} \mathrm{mi)}$ southeast. Mercury, a restricted access government facility that houses support facilities for the NTS, is located in the southeast corner of the NTS, and is about $22 \mathrm{~km}$ (14 mi) south of the Area 5 RWMS.

The Area 5 RWMS is located in the northern part of the Frenchman Flat hydrographic basin, at the juncture of three coalescing alluvial fan systems (Snyder et al., 1995). Frenchman Flat is a roughly circular, topographically closed basin bounded by the Massachusetts Mountains on the north, the Buried Hills and Ranger Mountains on the east and southeast, Mount Salyer on the west, and Mercury Ridge and Red Mountain on the south (Figure 5-1). Elevations range between 1,600 m (5,250 ft) in the surrounding mountains to $939 \mathrm{~m}(3,080 \mathrm{ft})$ at Frenchman Flat Playa. The Area 5 RWMS is at an elevation of about 969 to $975 \mathrm{~m} \mathrm{(3,180} \mathrm{to} \mathrm{3,200} \mathrm{ft)} \mathrm{above}$ mean sea level. It is located about $3.8 \mathrm{~km}$ (2.4 mi) north of and 30 to $36 \mathrm{~m}$ (98 to $118 \mathrm{ft}$ ) above the playa.

For decades, Frenchman Flat has been a research, testing, and industrial land-use area. Atmospheric and underground nuclear tests were conducted in the basin. The closest underground test was about $2.4 \mathrm{~km}(1.4 \mathrm{mi})$ northeast of the Area 5 RWMS. Safety tests have also been conducted nearby, at the Gadgets, Mechanics, and Explosives site about $1.8 \mathrm{~km}$ (1.1 mi) southeast of the RWMS. The Nonproliferation Test and Evaluation Center (a hazardous materials research center formerly known as the HAZMAT Spill Center), and other active facilities which handle hazardous materials, are located in the Frenchman Flat basin. For further detail on geography and land use, see the PA (Shott et al., 1998).

\subsection{Meteorology}

The NTS is located between the northern boundary of the Mojave Desert and the southern limits of the Great Basin Desert. This "transitional desert" is considered to be typical of either the dry mid-latitude or dry subtropical climatic zones. The climate is arid and characterized by low precipitation, a large diurnal temperature range, a large evaporation rate, and moderate to strong 
Revision: 0

Date: June 2006

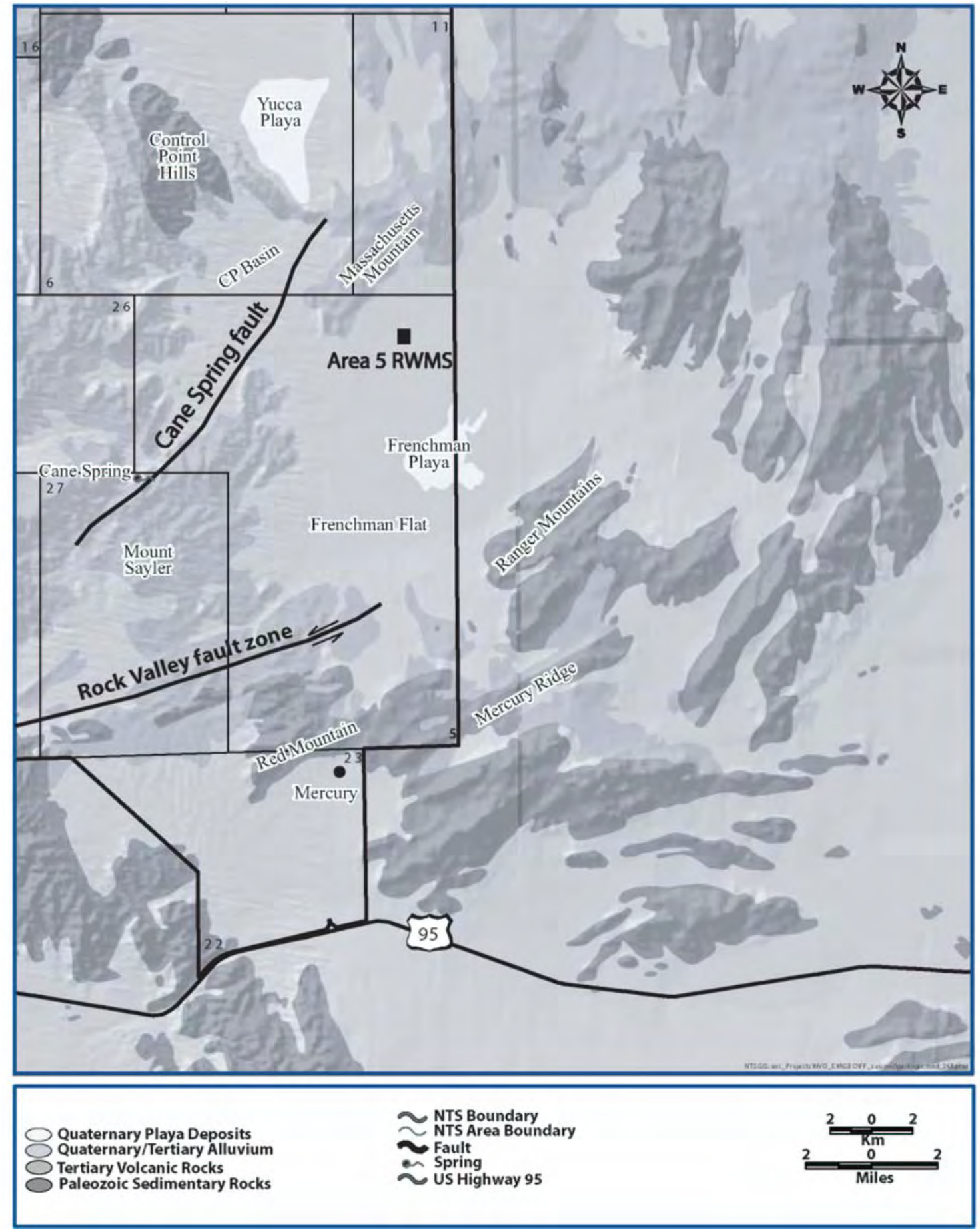

Figure 5-1. General Geologic Map of Frenchman Flat and Vicinity

From: Integrated Closure and Monitoring Plan for the Area 3 and Area 5 Radioactive Waste Management Sites at the Nevada Test Site (BN, 2005a).

winds. Detailed discussions on meteorology and climatology specific to the Area 5 RWMS are presented in the PAs (Shott et al., 1998; 1995) and the annual monitoring reports (e.g., BN, 2005c). 
The monitoring program fulfills basic regulatory requirements for meteorological monitoring in DOE O 450.1. It also provides data for calculation of PET, a measure of the exchange of water and heat between the earth's surface and the atmosphere, and an important component of the water balance calculation used to evaluate the potential for precipitation to infiltrate and percolate to the waste cells. The DOE maintains a two-level meteorology tower at each RWMS. The Area 5 RWMS meteorology station is located to the southeast of the Area 5 RWMS, about $100 \mathrm{~m}$ (328 ft) from Well Ue5PW-1 (Figure 5-2) and has been in operation since 1994. Data routinely collected include: precipitation, air temperature, humidity, wind speed and direction, barometric pressure, and solar radiation load. The air temperature, relative humidity, wind speed, and wind direction are monitored at two heights at the stations.

Other stations in Area 5 with similar conditions offer a longer period of record. Precipitation data have been collected since 1963 at Well 5B, approximately $6.4 \mathrm{~km}$ (4 mi) southwest of the

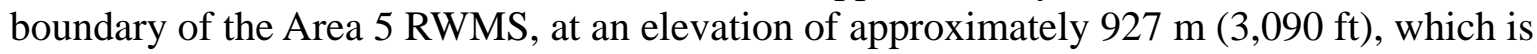
about $42 \mathrm{~m}$ (138 ft) lower than the Area 5 RWMS.

Meteorological data most relevant to potential cover performance, erosion, and contaminant transport are summarized below.

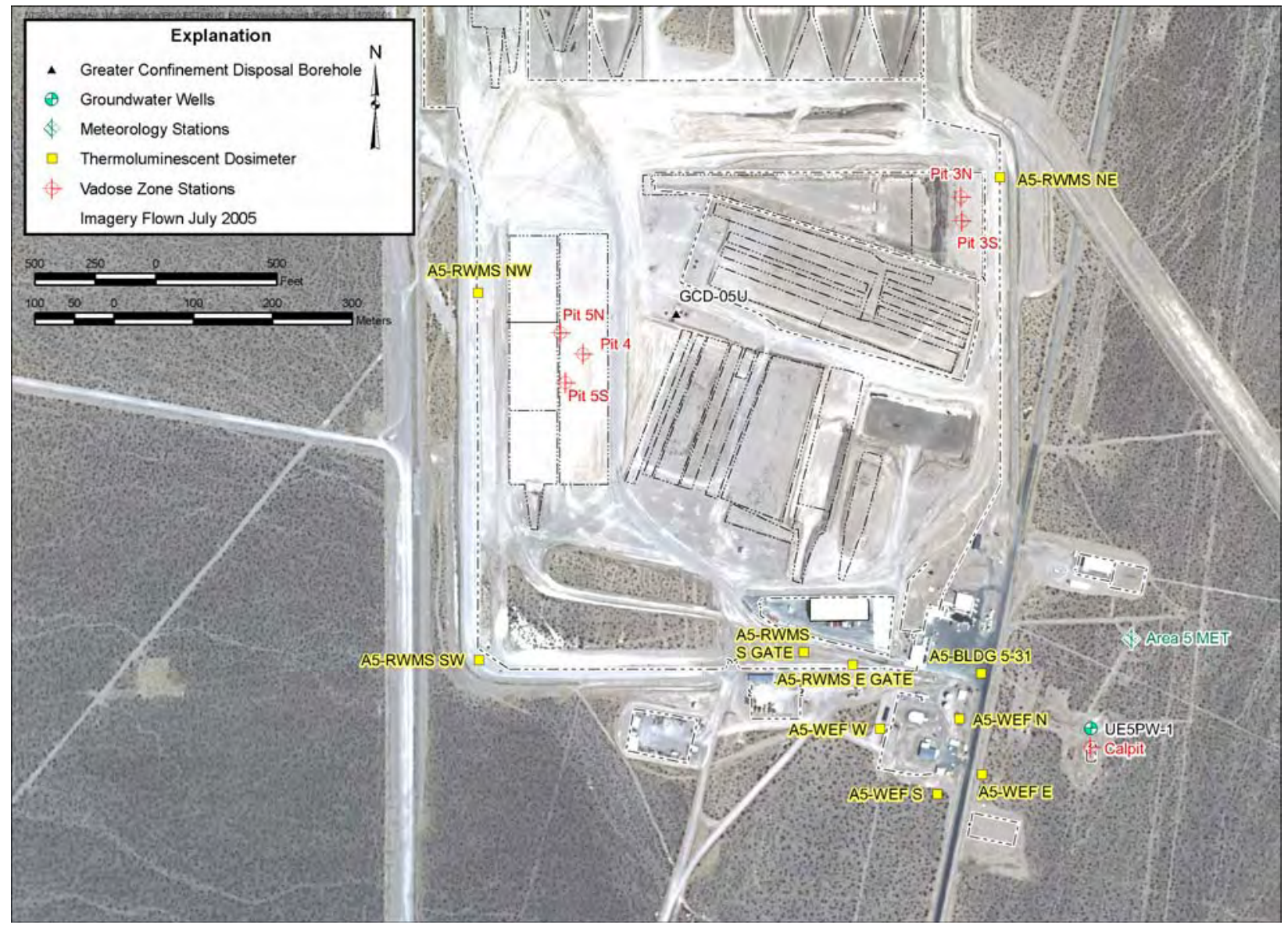

Figure 5-2. Monitoring Stations at the Area 5 Radioactive Waste Management Site

Source: 2004 Waste Management Monitoring Report, Area 3 and Area 5 Radioactive Waste Management Sites (BN, 2005c) 


\subsubsection{Precipitation}

Most precipitation in the Transitional Desert occurs in winter and summer. Winter precipitation is generally associated with transitory low-pressure systems originating from the west and occurring as uniform storms over large areas. Summer precipitation is generally associated with convective storms originating from the south or southwest and occurring as intense local events. The average annual precipitation on the NTS ranges from 7.6 and 25.4 centimeters $(\mathrm{cm})(3$ and 10 in), depending on elevation.

In Frenchman Flat, precipitation is low, yet highly variable. Average annual precipitation based on the 10-year record from 1995 to 2004 at the Area 5 RWMS meteorological station is 129 millimeters $(\mathrm{mm})$ (5.08 in) with a standard deviation of $64 \mathrm{~mm}$ (2.56 in). The maximum was $259 \mathrm{~mm}$ (10.20 in) in 1998 and the minimum was $38 \mathrm{~mm}$ (1.50 in) in 2002. The average annual precipitation based on a 42-year record from 1963 to 2004 at the Well 5B station $6.4 \mathrm{~km}$ (4 mi) south of the Area 5 RWMS is $125.1 \mathrm{~mm}$ (4.92 in) (BN, 2005c). Figure 5-3 depicts the precipitation record for Area Well 5B and Area 5 RWMS monitoring stations.

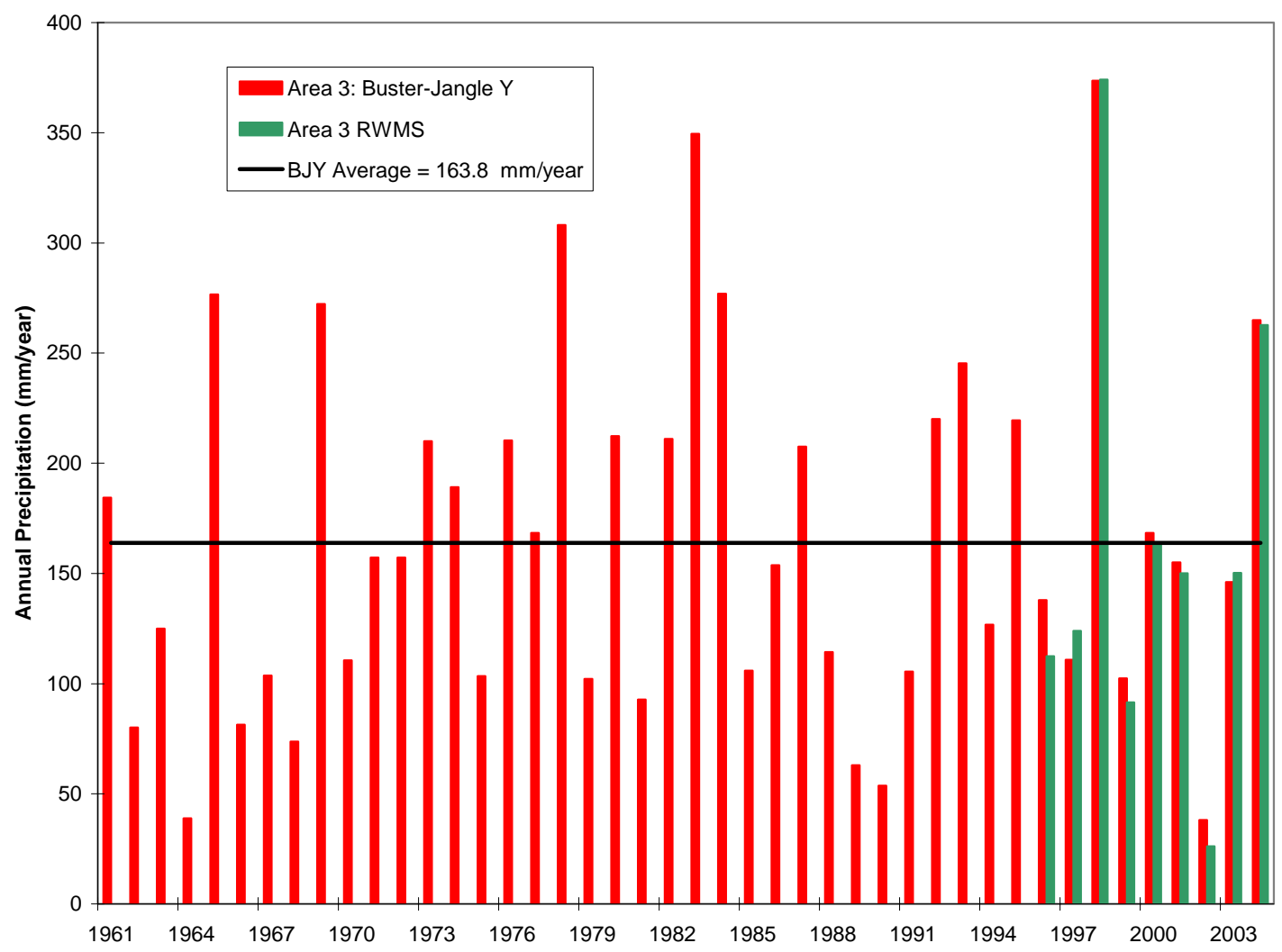

Figure 5-3. Historical Precipitation Record for Area Well 5B and Area 5 Radioactive Waste Management Site

Source: 2004 Waste Management Monitoring Report, page 37 (BN, 2005c) 


\subsubsection{Temperature}

Average daily temperatures at the NTS are between 2 degrees Celsius $\left({ }^{\circ} \mathrm{C}\right)(35$ degrees Fahrenheit $\left.\left[{ }^{\circ} \mathrm{F}\right]\right)$ in January to $24^{\circ} \mathrm{C}\left(75^{\circ} \mathrm{F}\right)$ in August. Large daily fluctuations are common on the valley floors (BN, 2005a).

At the Area 5 RWMS, in 2004, the minimum recorded temperature at $3 \mathrm{~m}(9.8 \mathrm{ft})$ above ground surface was $-9.7^{\circ} \mathrm{C}\left(14.5^{\circ} \mathrm{F}\right)$ and the maximum was $41.1^{\circ} \mathrm{C}\left(106.0^{\circ} \mathrm{F}\right)(\mathrm{BN}, 2005 \mathrm{C})$.

\subsubsection{Potential Evapotranspiration}

Potential evapotranspiration at the NTS is high because of the large-incident solar radiation and high average wind speeds, and occurs at a potential, or energy-limiting, rate. It is calculated using several widely accepted equations. The Penman Equation was the calculation method used in most data reports through 2001. A modified version of the radiation-based equation of Doorenbos and Pruitt (1997) has been used since 2002. Results are similar, but the Doorenbos and Pruitt (1997) approach reduces input requirements because no net radiation data are used. The equation calculates PET from hourly measurements of solar radiation, air temperature, relative humidity, wind speed, and barometric pressure (BN, 2005c).

Table 5-1 shows total annual PET and precipitation through time at the Area 5 RWMS. Average annual PET from 1995 through 2004 was $152.87 \mathrm{~cm}$ (60.19 in) and ranged from 139.05 to $165.30 \mathrm{~cm}$ (54.74 to $65.08 \mathrm{in}$ ). The minor variations between years can be attributed to natural variations in energy conditions such as wind speeds and solar radiation (heat). The ratio of PET to precipitation ranged from 6 to 54 and averaged 17 over the ten years of record. On an annual basis, even in wet cool years, evaporative demand is high.

Seasonal variations and relationship to other factors of the water budget are discussed further in the discussions of lysimeter data and vadose zone hydrology in Section 5.6.

\subsubsection{Wind}

The open and sparsely vegetated Frenchman Flat basin is windy, and enhances evaporation rates. Wind speed and direction have been recorded at the Well 5B meteorology station since 1981 and at the Area 5 RWMS meteorology station since 1994. Localized differential heating of the land surface and orographic effects can affect local conditions. Although the overall order of magnitude of the velocity and directional frequency distribution are very similar for the two monitoring stations, there are some slight differences that may partly be explained by geography. The position of the Area 5 RWMS station is closer to the mountains bounding the north end of the basin, than the Well 5B station which is more central. The Area 5 RWMS station gets more wind from the north than Well 5B. 
Table 5-1. Annual Potential Evapotranspiration Compared to Annual Precipitation, Area 5 RWMS

\begin{tabular}{|c|c|c|c|}
\hline Year & $\begin{array}{c}\text { Precipitation } \\
\mathbf{( c m )}\end{array}$ & $\begin{array}{c}\text { Potential } \\
\text { Evapotranspiration (cm) }\end{array}$ & $\begin{array}{c}\text { Ratio } \\
\text { PET:PPT }\end{array}$ \\
\hline 1995 & 15.18 & 146.41 & 9.64 \\
1996 & 7.59 & 158.87 & 20.94 \\
1997 & 8.29 & 149.98 & 18.09 \\
1998 & 23.91 & 139.05 & 5.82 \\
1999 & 10.46 & 147.51 & 14.10 \\
2000 & 12.82 & 149.34 & 11.65 \\
2001 & 10.47 & 153.60 & 14.68 \\
2002 & 3.05 & 165.02 & 54.12 \\
2003 & 13.98 & 153.57 & 10.99 \\
2004 & 18.74 & 165.30 & 8.82 \\
\hline \hline MEAN & 12.45 & 152.87 & $\mathbf{1 6 . 8 9}$ \\
\hline VARIANCE & $\mathbf{4 8 \%}$ & $\mathbf{5 \%}$ & $\mathbf{8 2 \%}$ \\
\hline
\end{tabular}

Notes:

$\mathrm{cm}=$ centimeters

PET = potential evapotranspiration

$\mathrm{PPT}=$ total annual precipitation

Wind rose diagrams illustrate the frequency of wind velocities with respect to wind-source direction over a period of record, using hourly wind data measured at a height of $3.0 \mathrm{~m} \mathrm{(10} \mathrm{ft)}$ above the ground surface. The 2004 wind rose from the Area 5 RWMS meteorology station is presented in Figure 5-4 (BN, 2005c). In 2004, the average daily wind speed was 2.6 meters per second (m/s) (5.8 miles per hour [mph]) and the maximum gust measured was $20.4 \mathrm{~m} / \mathrm{s}$ (45.6 mph).

Figure 5-5 shows hourly wind speed and direction data from 1994 through 2004 at the Area 5 RWMS Meteorology Station. Figure 5-6 shows hourly wind speed and direction from 1981 to 2004 at the Well 5B Meteorological Station a few miles southwest of the Area 5 RWMS. The wind speeds on these summary diagrams are in knots. Ten knots is approximately equivalent to a rate of $5.14 \mathrm{~m} / \mathrm{s}$ or $11.51 \mathrm{mph}$. Only 2 percent of the surface wind readings were rated as calm at the Area 5 RWMS station and 3 percent at Well 5B station. Most of the wind comes from the southwest and north. Maximum wind speeds were generally less than 30 knots, and most of the hourly wind speeds over 5 knots came from the southwest.

Appendix D contains monthly wind data for the Area 5 RWMS from 1994 through 2004. The diagrams show seasonal trends. The site is generally windy. Winds are primarily from the southwest during the spring and summer months and from the north during the winter months. Wind speeds tend to be greatest in the spring. Surface wind speed was never calm in April and was categorized as calm only 6 percent of the time in November. 


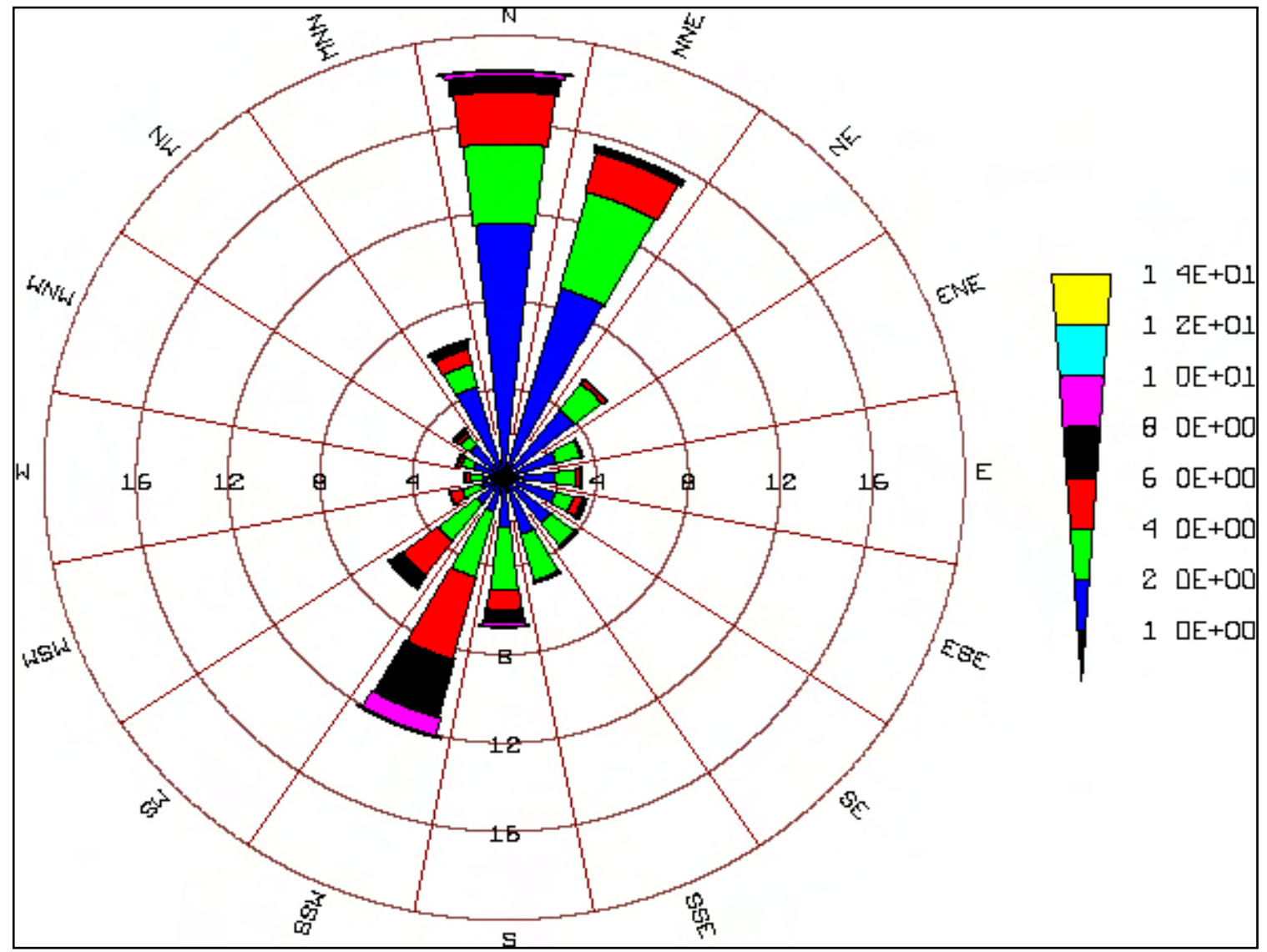

Figure 5-4. 2004 Wind Rose Diagram for the Area 5 RWMS Meteorology Station

Note: Distance from the center reflects percent frequency; petal shading shows wind speed in meters per second at a height of 3 meters above ground surface, and petal direction indicates the direction of the wind source.

\subsection{Vegetation (Flora) AND WildLife (FAuna)}

The information in this Section is largely derived from the ICMP (BN, 2005a) and from the Characterization Report Operational Closure Covers for the Area 5 RWMS (BN, 2005d). The vegetation of the Area 5 RWMS vicinity is characterized in Hansen and Ostler (2003). Descriptions of plant and animal species and communities near the Area 5 RWMS are also presented in the PA (Shott et al., 1998). Additional detailed discussions of NTS ecology are presented in Wills and Ostler (2001).

The nature and distribution of plants and animals and their ecological interactions are of interest both as agents of contaminant transport and as potential receivers of contaminants. Vegetation and burrowing wildlife affect the permeability of near-surface soil and alluvium. They have a complex role in potential transport of water and radioactive particles through soil landfill covers. DOE O 450.1, "Environmental Protection Program," includes specific requirements for the protection of natural resources and for evaluation of the potential impacts to biota in the vicinity of DOE activities, including waste management. Details of the monitoring process are in the BN OI for RWMS biota monitoring, BN OI-2154.110, Biota Sampling and Sample Preparation for Animals and Vegetation. 
Characterization Report 92-Acre Area Section: Site Characteristics

Revision: 0

Date: June 2006

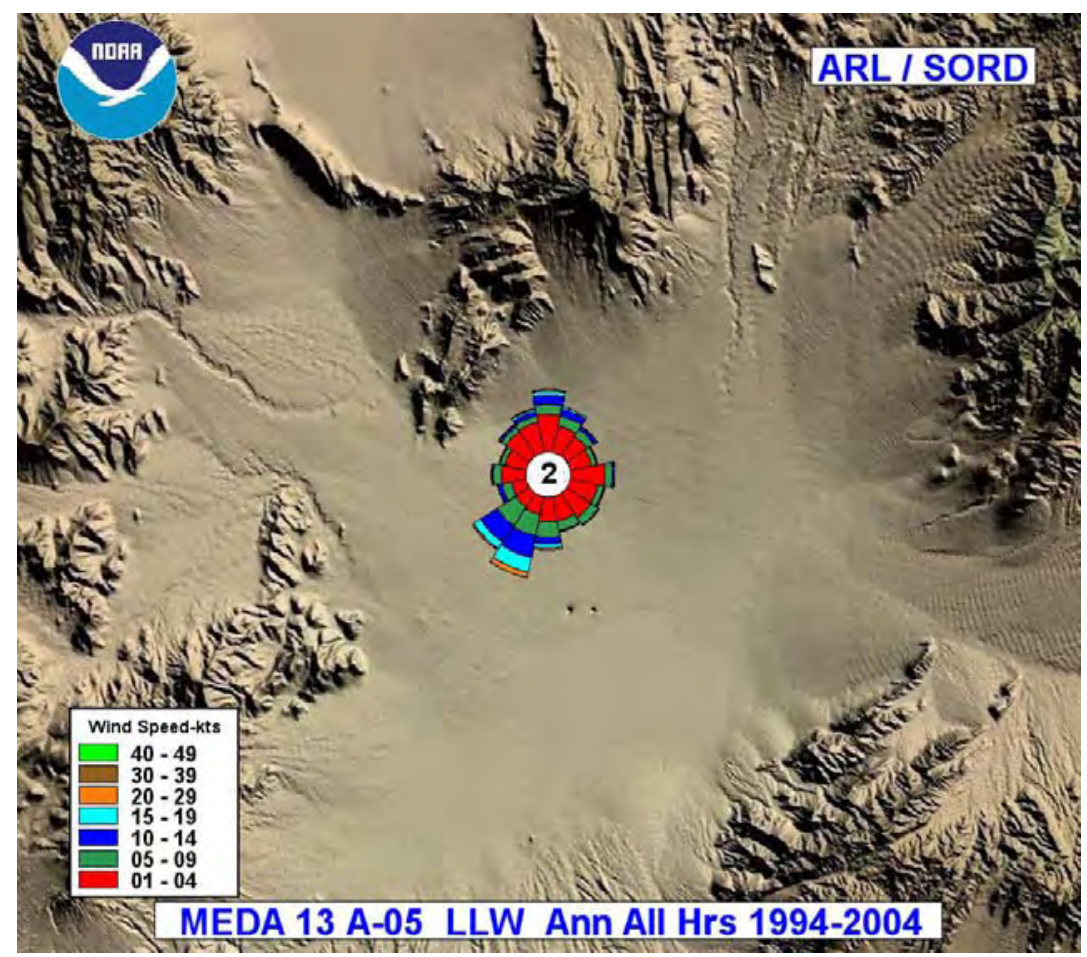

Figure 5-5. Nevada Test Site, Area 5 RWMS, Wind Rose for 1994 to 2004

Source: DOE webpage, http:/sord.nv.doe.gov/products/climate/wind-roses/MEDA/meda-13/fancy colors/rose 13.jpg, accessed on July 27, 2005.

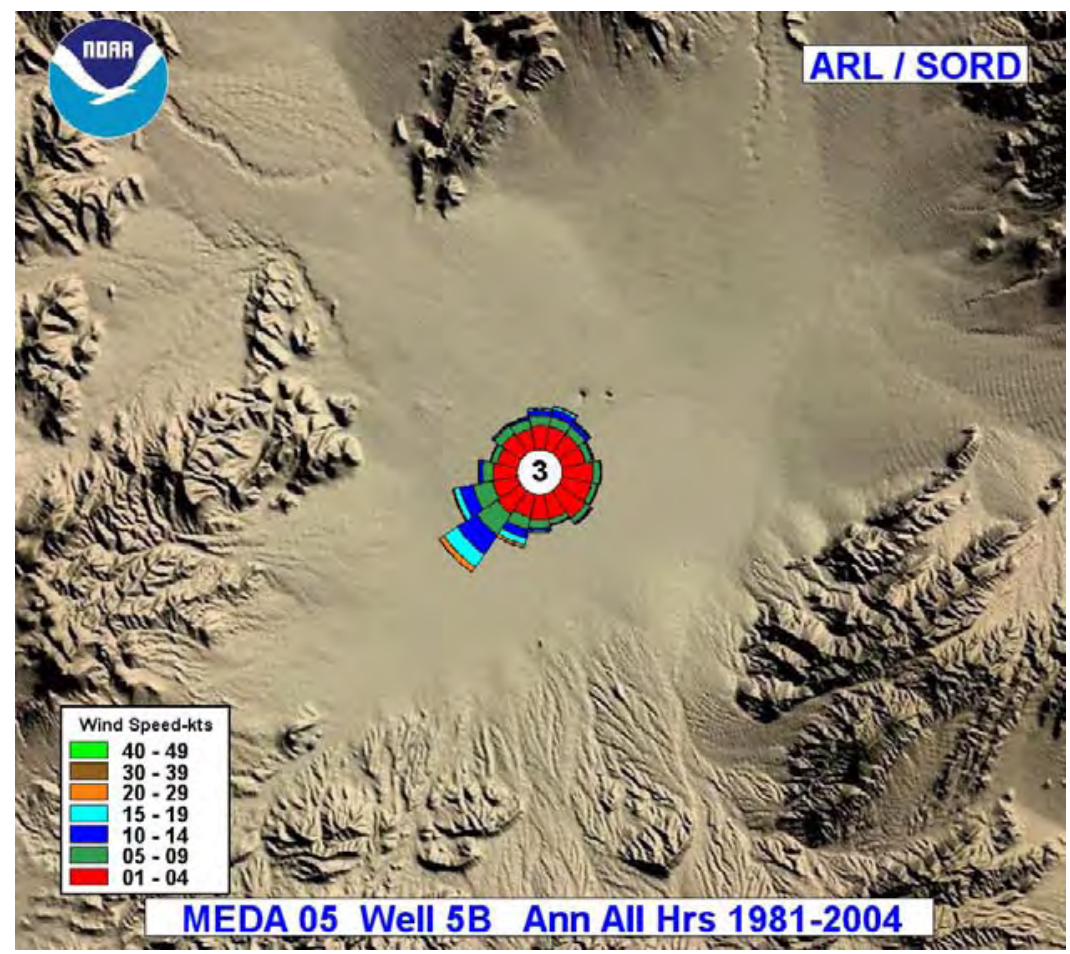

Figure 5-6. Nevada Test Site, Well 5B, Wind Rose for 1981 to 2004

Source: DOE webpage, http:/sord.nv.doe.gov/products/climate/wind-roses/MEDA/meda05/fancy_colors/rose_13.jpg, accessed on July 27, 2005. 
A DOE committee developed a DOE technical standard, DOE-STD-1153-2002 A Graded Approach to for Evaluating Radiation Doses to Aquatic and Terrestrial Biota, which established conservative protective dose limits, based on current understanding. DOE operating policies are designed to ensure these limits are not exceeded. The current standards are:

Dose limit to terrestrial plants $=1 \mathrm{rad} /$ day $(10$ milliGray $[\mathrm{mGy}] /$ day $)$

Dose limit to terrestrial animals $=0.1 \mathrm{rad} / \mathrm{day}(1 \mathrm{mGy} /$ day $)$

The following subsections focus primarily on biota characteristics and monitoring relevant to vadose-zone hydrology and contaminant transport.

\subsubsection{Vegetation (Flora)}

The type, maturity, and density of vegetation affects runoff characteristics, infiltration characteristics, the temperature of surface soils, wind speeds at ground surface, and consequently, the potential for evapotranspiration, soil erosion, and infiltration of rainwater. Vegetation is one factor among many affecting the maintenance of landfill covers and potential movement of water within the first few meters of soil and alluvium. Rooting depth is closely tied to soil moisture availability. The potential for plants to enhance vertical movement of water downward towards buried waste is offset by their use of water to live and grow. Decomposition of roots provides channels for water and vapor and may enhance infiltration and percolation through the rooting depth, but plants remove water from the soil, store it in biomass, and transpire moisture back to the atmosphere. Further implications of vegetation with respect to water budget are discussed in the context of the lysimeter data and vadose zone hydrology (Section 5.6) and in the studies referenced. Because plants can take radionuclides from the soil, concentrate them in their biomass, and potentially release some to the atmosphere via transpiration, vegetation can also be a factor in the movement of radionuclides in the near surface environment.

Plants are often an integral part of a landfill soil-closure cover system, whether the plants are intentionally selected and planted in ways to maximize the benefits of the vegetative cover, or whether the cover is designed to allow the gradual natural population of the area by surrounding species. Plant evapotranspiration minimizes potential water transport through the cover and the plant canopy and roots help control erosion of the surface by wind and rain.

Studies on floral communities occurring within Frenchman Flat (Romney et al., 1973; Hunter and Medica, 1989; Ostler et al., 2000; and Beatley, 1976) have classified the vicinity of the Area 5 RWMS as a Larrea-Ambrosia Mojave Desert community. Mojave Desert communities can have highly variable floristic compositions, but all are dominated by creosote bush and various co-dominant shrubs. Shrub coverage varies from 7 to 23 percent for Mojave Desert communities on the NTS (Beatley, 1976). Several reports indicate plant communities near the Area 5 RWMS are dominated by creosote bush, including Ostler et al., (2000). Hansen and Ostler (2003) noted the Larrea-Ambrosia shrublands at the NTS are actually typically dominated by white bursage (Ambrosia dumosa) in terms of total biomass, relative abundance, and cover. However, because the creosote are larger plants, they appear to dominate the landscape. 
Schockley goldenhead (Acamptopappus shockleyi) was another common shrub species observed at two of three study sites investigated near the Area 5 RWMS.

Roots of shrubland species that grow at the NTS are mostly confined within the top $5 \mathrm{~m}$ (16.4 ft) of soil (see studies by Hansen and Ostler [2003], Foxx et al. [1984a and 1984b], and Tierney and Foxx [1987]). The roots of Mojave Desert and transitional desert plants at the NTS are concentrated near the surface, to maximize capture of infiltration (Winkel et al., 1995; Hansen and Ostler, 2003). Availability of oxygen has been found to limit creosote root depths, perhaps even more than the availability of soil moisture (Personal Communication, D. Hansen, September 20, 2005).

All of the species observed at the Area 5 RWMS have shallow root systems, and observed root depths are generally less than $2 \mathrm{~m}(6.6 \mathrm{ft})$. Wallace and Romney (1972) described root systems of plants excavated from a wash in Rock Valley on the NTS, at a study site selected because of an absence of caliche hardpan, which can restrict rooting depths. Creosote bush roots reached $168 \mathrm{~cm}$ (66 in) below surface, but over 82 percent of the creosote roots were in the top $30 \mathrm{~cm}$ (12 in) of soil. White bursage plant roots reached up to $50 \mathrm{~cm}$ (20 in), but most of the roots were in the top $20 \mathrm{~cm}$ (8 in) of soil. About 85 percent of the Schockley goldenhead roots were in the top $20 \mathrm{~cm}$ (8 in) of soil, and none reached below $40 \mathrm{~cm}$ (16 in) depth. Other less abundant shrub species were also shallowly rooted: desertthorn roots reached $122 \mathrm{~cm}$ (48 in) below surface, Mormon tea roots reached $91 \mathrm{~cm}$ (36 in) below surface, and winterfat roots reached $64 \mathrm{~cm}$ (25 in) below surface.

Wallace et al. (1980) also excavated root systems of several Mojave Desert species at the NTS. The roots were distributed in the top $51 \mathrm{~cm}$ (20 in), except for fourwing saltbush and shadscale. Less than 2 percent of the roots of these two species were found below $51 \mathrm{~cm}$ (20 in). Beatley (1969) noted that winter annuals root in the top $20 \mathrm{~cm}$ (8 in.) of soil. Wirth et al. (1999) also compiled rooting depths of various plant species found on the NTS.

Hansen and Ostler (2003) studied rooting characteristics of vegetation near to and at the Area 3 and Area 5 RWMSs. In August 2001, excavations and observations of the pit walls at P08U in

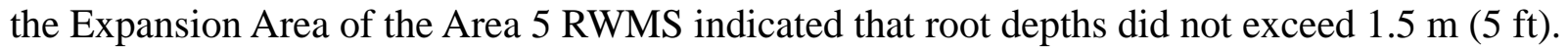
Small isolated root hairs, apparently unrelated to the current plants, were found below $1.5 \mathrm{~m}$ (5 ft) depth. Most creosote bush roots were concentrated in the top $2 \mathrm{~m}(6.6 \mathrm{ft})$ of soil and the largest average maximum rooting depth for creosote at the three study plots near to, but outside of, the Area 5 RWMS was less than 116 cm (3.8 ft). Raytheon Services Nevada ([RSN], 1991) noted that modern and ancient roots observed in the pit walls often have up to a 15-cm- (6-in)diameter zone of carbonate cementation around them, indicative of water or vapor migration in these zones.

The natural vegetation in the vicinity of the Area 5 RWMS is sparse. Total shrub cover at three study plots varied from 18.6 percent to 32 percent (Hansen and Ostler, 2003).

Several studies have estimated the time for disturbed areas to naturally revegetate and the characteristics of communities likely to become established. These studies give an indication of how long it may take a native alluvium landfill cover to naturally revegetate. Sutter et al. (1993) 
suggests revegetation of the Area 5 RWMS waste covers, whether managed in the beginning or left to occur naturally, will likely progress from bare soil to desert shrubland in less than 50 years. However many studies suggest recovery of vegetative cover may take much more time. Webb et al. (2003) looked at changes in plots originally established at the NTS by Dr. Janice Beatley in 1963. The plots had been disturbed by fires and other factors, and were ecologically monitored from 1963 to 1975 and from 2000 to 2003 . Webb concluded that species compositions of disturbed plots compared to undisturbed plots at the NTS are very different. Although some vegetative cover will reestablish in 50 years, as long as a millennium may be required for recovery of the native species composition.

Similarly, Ostler et al. (2002) studied recovery of plants at sites disturbed by military activities in the Mojave Desert and projected that recovery may require hundreds of years to achieve predisturbance levels of vegetation cover in arid lands.

Angerer et al. (2004) studied plant succession on disturbed sites at Yucca Mountain, Nevada. The study area included the west edge of the NTS. Extrapolation of observations indicated approximately 845 years would be required for the amount of cover on disturbances to reach that of undisturbed areas. Estimates of individual recovery rates for 10 dominant species ranged from 31 years to 1,100 years. Time to develop a plant community very similar to the original undisturbed community would be much greater. Angerer et al. (2004) cites several other studies of plant succession in disturbed areas in the Mojave Desert with similar rates.

Even with predicted climatic changes of $3^{\circ} \mathrm{C}\left(37^{\circ} \mathrm{F}\right)$ warmer and then $2^{\circ} \mathrm{C}\left(35^{\circ} \mathrm{F}\right)$ cooler and 50 percent wetter conditions, creosote is likely to continue to be the dominant shrub in the Area 5 RWMS Area for the foreseeable future (RSN, unpublished written communication, 1991). The PA prepared for the TRU material in four of the GCD boreholes (Cochran, Beyeler, et al., 2001) suggesting deeper-rooted plants such as piñon and juniper might enter the Area 5 RWMS Area under glacial conditions. Hansen and Ostler (2003) noted a big sagebrush community could eventually result if the climate became sufficiently cooler and wetter at the Areas 3 and 5 RWMSs. However, piñon and juniper trees are unlikely to become established at the RWMS sites, which have deep soils and are in valley bottoms vulnerable to drought and fire. Therefore, even under wetter, cooler conditions, rooting depths of native plant communities are likely to remain shallow. Additional discussion on NTS vegetation can be found in Wills and Ostler (2001) and in Hansen and Ostler (2003).

\subsubsection{Wildlife (Fauna)}

Fauna have a potential role in transport of radioactive contaminants through burrowing and the food chain.

Fauna within the Mojave Desert plant communities at Frenchman Flat are diverse. Invertebrates, particularly insects, are the most abundant (O'Farrell and Emery, 1976). Ants and termites are the most numerous burrowing insects on the NTS (O'Farrell and Emery, 1976). Allred et al. (1963) report 20 ant species for Larrea-Ambrosia Mojave Desert communities. Vertebrates are less numerous and diverse. They include game and fossorial (burrowing) species. Both small and large burrowing mammals are present in the areas of the RWMSs. Rodents are the most 
common of the mammalian species on the NTS (Allred et al., 1963). For a summary on the NTS fauna, see Shott et al., 1998; Winkel et al., 1996; and Thompson, 1993.

The depth of burrowing is closely tied to soil conditions and plant rooting depths. The majority

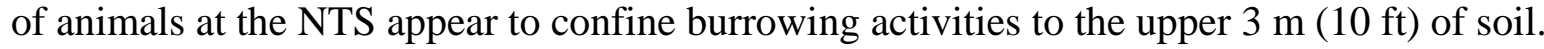

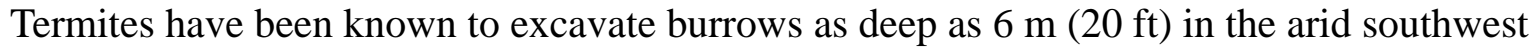
(Thompson, 1993); however, because plant roots are a primary food source for termites, their burrowing depths are also closely related to rooting depth. Creosote and other shrubs with shallower rooting depths predominate around the Area 5 RWMS (see previous section); therefore, termites in the vicinity are unlikely to be found below $2 \mathrm{~m}$ (6.6 ft) depth.

Recent studies suggest termites have little potential to move contaminated materials. Ants may burrow deeper. The volume of material moved from the subsurface to the surface by these insects is small (Personal Communications, J. Tauxe and G. Shott, November 16, 2005).

Vertebrate animal burrows were noted as modern and ancient post-depositional during an evaluation of Area 5 RWMS surface geology by Raytheon Services Nevada (September 1991). Modern burrows observed at the RWMS tend to be below shrubs. Most of the burrows are 5 to $10 \mathrm{~cm}$ (2 to 4 in) in diameter and extend below ground surface a few tenths of a meter. Larger burrows, about $20 \mathrm{~cm}$ ( 8 in) diameter, are much less abundant. Many modern burrows were observed extending to the rooting depth, about $1.3 \mathrm{~m}(4.3 \mathrm{ft})$, in the walls of "Pit 4C" (T04C from mapped location). One inactive burrow was found to $3.4 \mathrm{~m}(11.2 \mathrm{ft}$ ), but the observers suspected it may have been dug from the side wall of the pit due to a ledge near the opening (RSN, 1991).

Neptune and Company is currently writing a report for NNSA on recent biota characterization studies. The results have not been published yet, however the new data have been used to modify some of the biota input parameters for the Area 5 RWMS GoldSim probabilistic model. The Area 5 RWMS PA addendum due to be published in FY 2006 incorporates these model updates (Personal Communication, G. Shott, November 16, 2005).

\subsubsection{Biota Monitoring}

At the Area 5 RWMS, biota monitoring has mainly focused on sampling vegetation for tritium. Plant tissue has also been analyzed for alpha- and gamma-emitting radionuclides and Sr-90. Tritium is the primary radionuclide monitored due to its high mobility as tritiated water. The cycle of plant uptake and transpiration is one of the mechanisms that transport tritium up through waste covers and into the atmosphere, in addition to gaseous diffusion, gaseous advection, bioturbation, and evaporation (BN, 2005c, 2004c).

Plant roots absorb radionuclides from soil water and draw the radionuclides up into the leafy parts of the plant. Potential uptake is affected by root depth, density, and activity; the ability of plants to concentrate radionuclides; plant biomass production and turnover; soil type; climate; and weather. Studies by Sheppard and Evenden (1988), Whicker (1978), and Dreesen and Marple (1979) document the variability in the ability of plants to take up radionuclides. The 
amount of tritium released into the atmosphere by plant transpiration is affected by several factors including plant size, species, and available moisture.

Vegetation from on and near waste covers, as well as vegetation from control areas far from waste covers, is usually sampled in mid-summer. Timing of the sampling is important because vegetation is forced to remove soil water from greater depths (closer to waste) as surface soils dry out in summer. Plant water is extracted from the vegetation samples by room temperature vacuum distillation and analyzed by liquid scintillation for tritium.

If tritium concentrations in vegetation are exceedingly high, or if animal burrows on or near waste covers are observed in significant numbers, wild animals and soil from animal burrows may be sampled. Vegetation sampling may be limited year to year, depending on rainfall and waste cover operations during operational closure. Biota monitoring data are included in the annual waste management monitoring reports for the Areas 3 and 5 RWMSs. The most recent available published results at the time of report preparation were for the sampling event in 2002. The results of the 2005 sampling will be published in the 2005 Waste Management Monitoring Report, Area 3 and 5 Radioactive Waste Management Sites, to be published in FY 2006.

The tritium concentrations found in 1999, 2000, 2001, and 2002 were much lower than those measured in 1995 and 1996 (BN, 2005c). The monitoring staff speculates that samples collected in the mid 1990s may have been from areas closer to the sources of tritium than vegetation samples collected in later years, due to a change in cover maintenance. More vegetation was present on the covers in the mid 1990s than in later years (Personal Communication, R. Warren via D. Hudson, September 6, 2005).

Biota should continue to be monitored for tritium as part of a multi-phase program. Potential tritium migration at the Area 5 RWMS is monitored through multi-depth soil-gas sampling at the GCD-05U disposal unit, air quality monitoring, and biota monitoring. Low levels of tritium have been found in soil-gas near the waste, and traces of tritium have been found in plant tissue and air samples. Monitoring data indicate that there may be an upward pathway for tritium migration, possibly through diffusion and plant transpiration processes.

\subsection{Geology}

A detailed description of the geology of Frenchman Flat is in the PA for the Area 5 RWMS (Shott et al., 1998). Much of the following description is extracted from the ICMP (BN, 2005a).

\subsubsection{Regional Geology}

A sequence of rocks at the NTS composed of Proterozoic and Paleozoic, primarily marine, sedimentary rocks; locally intrusive Cretaceous granitic rocks; Miocene volcanic rocks; and post-volcanic sand and gravel would be approximately 10,500 $\mathrm{m}(35,000 \mathrm{ft})$ thick if stacked at one location according to age (Frizzell and Shulters, 1990). The geometry of these rocks is complex. The Proterozoic and Paleozoic rocks were significantly deformed in Late Mesozoic time (approximately 70 million years ago). At that time, older rocks were thrust eastward tens 
of $\mathrm{km}$ (tens of mi) over younger rocks, in some places resulting in repetition of the sequence of rocks (Orkild, 1983). In mid-Tertiary (Miocene) to Quaternary time, the Proterozoic and Paleozoic rocks and the overlying Miocene volcanic rocks were deformed by large-scale extensional block faulting, which is largely responsible for the present Basin and Range topography in Nevada. The extensional faulting is thought to have occurred in two phases across the NTS. The initial phase, about 16 to 14 million years ago, consisted of high-angle northwestand northeast-trending normal faults, and detachment faults (Cole et al., 1989). A second phase, younger than 11 million years ago, consisted of steeply dipping north-to-south-trending normal faults. This later phase is responsible for the basin-forming faults presently obvious in Yucca Flat (Dockery-Ander, 1984).

\subsubsection{Frenchman Flat Geology}

The mountain ranges surrounding Frenchman Flat consist primarily of Tertiary volcanic rocks and underlying Paleozoic sedimentary rocks (Figure 5-1). These ranges bound rotated and down-dropped blocks in the basin. Erosion of the mountain ranges has resulted in deposition of a significant thickness of alluvium. The stratigraphy of rocks within Frenchman Flat has been deduced from mapping and boreholes drilled for water wells and underground nuclear testing. Thickness of alluvium in Frenchman Flat ranges between 0 and 1,500 m ( 0 and 4,900 ft), based on recent drillhole and 3-D seismic reflection data. The alluvium directly below the Area 5 RWMS is approximately $914 \mathrm{~m}$ (3,000 ft) thick (BN, 2005f).

Basalt flows with numerical ages of 8.6 and 8.4 million years are interbedded in the alluvium in the northern part of Frenchman Flat, approximately $270 \mathrm{~m}(900 \mathrm{ft})$ below the ground surface (Well ER-5-3 log [NNSA/NSO, 2005b]). These flows tend to separate alluvium with a predominant percentage of Tertiary-aged tuff from underlying alluvium with a predominant percentage of Paleozoic-aged sediments (Snyder et al., 1994). This suggests that the source of alluvium in northern Frenchman Flat changed from being predominantly from the northeast to being predominantly from the north about 8.5 million years ago.

The alluvium is underlain by interbedded Tertiary ash-flow and ash-fall tuff estimated to be over $1,190 \mathrm{~m}(3,900 \mathrm{ft})$ thick directly below the Area 5 RWMS. On the basis of 3-D seismic reflection data (BN, 2005f), the upper surface of the underlying carbonate rocks is about 2,100 $\mathrm{m}$ $(6,900 \mathrm{ft})$ below the surface at the Area $5 \mathrm{RWMS}$, and perhaps as deep as 2,740 $\mathrm{m}(9,000 \mathrm{ft})$ near the center of the basin. A well recently drilled in northern Frenchman Flat as part of the Underground Test Area (UGTA) Program showed the top of the carbonate rocks to be 1,426 m $(4,678 \mathrm{ft})$ below surface, approximately $3.2 \mathrm{~km}$ (2 mi) northeast of the RWMS.

Principal faults in Frenchman Flat are the Cane Spring Fault and the Rock Valley Fault (Figure 5-1). The Cane Spring Fault is a left-lateral, strike-slip fault that strikes southwest to northeast in the northern part of Frenchman Flat, $6.4 \mathrm{~km}(4 \mathrm{mi})$ northwest of the RWMS. The Rock Valley Fault is a left-lateral, strike-slip fault with a minor dip-slip component (down to the north) that strikes southwest to northeast in the southern part of Frenchman Flat, about $8.8 \mathrm{~km}$ (5.5 mi) south of the RWMS. Both of these faults are active and responsible for earthquakes within the recent past (see Section 5.10.1, Seismicity). 


\subsection{SURFACE WATER}

No permanent surface water is present within Frenchman Flat, with the exception of small artificial impoundments and Cane Spring, which issues from a perched aquifer recharged from infiltration through fractures in the nearby mountains. Cane Spring is approximately $14.4 \mathrm{~km}$ (9 mi) southwest of the Area 5 RWMS. Alluvial fans within Frenchman Flat are cut by numerous arroyos that drain storm runoff to the playa. Water that accumulates on the playa typically evaporates or infiltrates, or both, within a short period of time. Frenchman Playa is approximately $6.4 \mathrm{~km}$ (4 mi) southeast of the Area 5 RWMS (BN, 2005a).

Design of structures and closure covers that can best accommodate run-on from precipitation events over long periods of time must rely on historical precipitation and discharge data. Precipitation data have been collected at various locations around the NTS for several decades. However, until recently, the locations of data collection were not near the middle reaches of watersheds that potentially collect and discharge waters to the vicinities of facilities. To collect precipitation and discharge data relevant to PA and eventual design activities, two precipitation gauges and two flumes were installed in FY 2000 in watershed channels near the Area 5 RWMS. A precipitation gauge and a flume are located in a watershed channel northwest of the Area 5 RWMS. The flume was installed in FY 2000. The intent is to collect precipitation and discharge data through FY 2007, after which, activities associated with final closure of the currently active, 92-Acre Area of the Area 5 RWMS will be initiated. Flooding hazard assessment data are discussed in Section 5.10.3.

\subsection{VADOSE ZONE}

Many studies and models have been completed that have contributed to our understanding of the stratigraphy and physical properties of the unsaturated zone in Area 5, the physical properties of the existing operational covers, and the potential for movement of water through the vadose zone. In the early 1990s, several studies were conducted which characterized the unsaturated alluvium in the vicinity of the Area 5 RWMS. The studies provided physical property data useful for further evaluation of: hydrogeologic processes; the potential for contaminant transport, erosion, and subsidence; and other factors that must be considered in planning for closure of Area 5 RWMS disposal cells. These studies also enhanced environmental monitoring capabilities in the immediate vicinity of the Area 5 RWMS. Several of the original data reports, which had a very limited distribution, were recently published by NNSA for broader release. This section summarizes a few key results for the natural unsaturated deposits. The operational landfill cover data are presented in Section 5.11.

\subsubsection{Key Studies Regarding Vadose-Zone Properties}

Some of the key studies and data reports for physical properties of the unsaturated alluvium in the vicinity of the Area 5 RWMS include: 


\section{Area 5 Site Characterization Project}

- Broad objective to characterize the subsurface hydrogeology of the Area 5 RWMS. Incorporated at least four subprojects listed below.

- $\quad$ Report: Area 5 Site Characterization project Report FY 1994 (Albright et al., 1994).

\section{Existing Excavations Project}

- Purpose was to characterize hydrologic properties of the near-surface alluvium which affect infiltration and redistribution of water and solutes, and to provide guidance for the design of sampling and testing programs.

- $\quad$ Scope included collecting core and bulk soil samples from 183 m-(600-ft)-long transects within Trench 8 and Pit 3, one approximately parallel and one approximately perpendicular to the principle direction of sediment transport. Evaluated spatial variability of gravimetric water content, bulk density, saturated conductivity, and particle size distribution. Characterized coarse and fine layers.

- Report: Hydrologic Data for Existing Excavations at the Area 5 RWMS, NTS, Nye County, Nevada (REECo, 1993a).

\section{Science Trench Boreholes Project}

- Purpose was to obtain physical, geochemical, and hydrologic property information for the near-surface alluvium in the vicinity of the Area 5 RWMS to support the RCRA Part B permit application for disposal of hazardous waste and to obtain the additional data needed to develop a three-dimensional model of water and gas flow and solute transport for the area. The study supplemented the Existing Excavations project.

- Scope included drilling and sampling seven boreholes by hollow stem auger up to $36.5 \mathrm{~m}$ (120 ft) deep along a 61-m (200-ft) transect across the Halfpint Alluvial Fan, parallel to the direction of sediment transport. The alluvium was too loose to leave the boreholes open for later installation of vadose zone monitoring wells. Four borings were subsequently drilled by the ODEX method to allow completion of the borings. Boring ST-1 was overdrilled and ST-2A, ST-4A, and ST-6A were step outs from the original exploratory borings. Laboratory tests and other studies conducted on selected cores and cuttings samples included:

- Geologic descriptions of stratigraphy and lithology,

- Mineralogy,

- Inorganic carbon,

- total organic carbon,

- Particle size distribution,

- Bulk density,

- Computed porosity,

- Saturated porosity,

- Saturated hydraulic conductivity (ksat),
- Van genuchten water characteristic curves,

- unsaturated hydraulic conductivity,

- Gravimetric and volumetric water content,

- Matric potential, water potential, and

- Tracers (chloride, bromide, stable isotopes, chlorine-36 $\left[{ }^{36} \mathrm{Cl}\right]$, and sulfate). 
- Results were documented in at least two reports including: Hydrogeologic Data for Science Trench Boreholes at the Area 5 Radioactive Waste Management Site, Nevada Test Site, Nye County, Nevada (REECo, 1993b) and Site Characterization Data from the Area 5 Science Boreholes, NTS, Nye County, Nevada (D. Blout et al., 1995).

\section{Shallow Soil Trenches Project}

- Purpose was to characterize soil parameters that affect the movement of water in the uppermost few meters of undisturbed soil in the vicinity of the Area 5 RWMS, partly to support a petition for a RCRA groundwater monitoring waiver and a RCRA exemption from leachate collection and detection systems at new cells.

- Scope included excavation of four trenches 1.5 to $3 \mathrm{~m}$ (4.9 to $9.8 \mathrm{ft}$ ) deep and 23 to $182 \mathrm{~m} 75.4$ to $597 \mathrm{ft}$ ) long, perpendicular to the depositional trend in different fan deposits. The researchers described soils and established stratigraphic relationships, ages of deposits, and alluvial stability with respect to erosion, and they collected multiple cores and grab samples along vertical transects for analysis. Analyses of various samples included gravimetric and volumetric moisture content, dry bulk density, porosity, Ksat, particle size distribution by sieve, organic matter, inorganic carbon, and ${ }^{36} \mathrm{Cl}$.

- Results were documented in at least two reports including: Hydrogeologic Characterization Data from the Area 5 Shallow Soil Trenches, Nevada Test Site, Nye County, Nevada, NNSA report DOE/NV/11718--1060 (BN, 2005g) and a written communication prepared for DOE regarding: Geological Components of Site Characterization and Performance Assessment for a Radioactive Waste Management Facility at the Nevada Test Site (Snyder et al., 1994).

\section{Pilot Wells Project}

- The purpose of the project was to characterize the uppermost aquifer and "to characterize the lithologic, stratigraphic, and hydrologic conditions that influence infiltration, redistribution, percolation, and chemical transport through the thick vadose zone in the vicinity of the Area 5 RWMS” (BN, 2005e).

- Scope involved drilling three wells to about $21.3 \mathrm{~m}$ (70 ft) below the water table and performing the following:

- Collecting cuttings samples approximately every .76 m (2.5 ft);

- Collecting cores at intervals of interest;

- Analysis and testing of selected core samples for

Ksat, moisture retention curves, volumetric water content,

- Gravimetric water content,

- Dry bulk density,

- Air permeability,

- Particle size distribution,
- Chloride,

- Bromide,

- Inorganic carbon,

- Organic carbon,

- Stable isotopes of hydrogen and oxygen,

- Water potential, ${ }^{36} \mathrm{Cl}$, and

- Clay mineralogy; 
- Testing of drill cuttings samples for particle size distribution, gravimetric water content, chloride, bromide, sulfate, inorganic carbon, organic carbon, and ${ }^{36} \mathrm{Cl}$;

- Geologic descriptions;

- Tracer tests to evaluate disturbance from air drilling;

- Radiological surveys;

- Installation and instrumentation of the wells;

- Soil gas surveys;

- Surface and borehole geophysical surveys;

- Nuclear logging;

- Air permeability tests;

- Water level measurements;

- $\quad$ Slug tests, in situ hydraulic conductivity tests; temperature profiles; and

- Baseline groundwater quality sampling and analysis.

- Results were documented in the following NNSA report: Site Characterization and Monitoring Data from the Area 5 Pilot Wells, DOE/NV/11718--1067 (BN 2005e).

Samples of core and cuttings from drilling the boreholes for the pilot wells were tested and analyzed for many parameters. The detailed data, as well as summaries of the descriptive statistics for the alluvium from all three wells, and the tuff encountered at UE5PW-3 with no differentiation between unsaturated and saturated zones, are in BN (2005e).

\section{Other Studies}

Air permeability studies (e.g., Sully et al., 1992); modeling studies (Crowe, Hansen, et al., 1998), Levitt et al., 1999; Lindstrom et al., 1993; Levitt et al., 1996); the PA studies for the Area 5 RWMS (Shott et al., 1998, 1995); and broader studies of the Great Basin (Tyler et al., 1996) provide further understanding of vadose-zone properties and potential for contaminant transport. Statistical studies provide analysis of spatial variability useful for defining modeling parameters (Sully et al., 1993; and Istock et al., 1994).

Figure 5-7 shows the approximate locations of borings, trenches, and wells in the vicinity of the RWMS. Many have been plugged and abandoned. Appendix C contains a table of sampling locations within Area 5, which includes basic location and descriptive data for these features. Appendix E, Borehole Data and Well Details, includes graphical logs of the Area 5 pilot wells (RCRA monitoring wells), well-construction details for the science trench boreholes completed as wells, and well-construction details for the Area 5 pilot wells.

In FY 2002, samples were collected from the Area 5 RWMS operational covers to document current physical characteristics including basic hydrogeological parameters. See Section 5.11 for discussion of the cover data.

General trends in properties for the unsaturated zone are summarized in the following sections. 


\subsubsection{Physical and Hydrologic Properties}

\subsubsection{Particle Size Distribution/Soil Classification Data}

Soil classes based on particle-size distributions can often be related to physical factors affecting the movement of water and contaminants including porosity and hydraulic conductivity trends. The uniformity of the lithologies, the stratification, and the lateral extensiveness of layers with different physical characteristics has a significant affect on how liquids, gases, and particles can move through the material.

At the shallow soil trenches, mean silt and clay content at trenches SST-1, SST-2, and SST-3 varied from 2.7 percent to 28.4 percent, with mean values for various depth interval sets ranging from 8.4 percent to 14.5 percent and coefficient of variance within depth interval sets of 23 percent to 61.9 percent. Mean gravel and other material above No. 4 mesh was 25.7 percent to 31 percent with less variability than the silt fraction. Dominant texture was silty sand at SST-1 and SST-3 and well-graded sand with silt at SST-2 (BN, 2005g).

At the Science Trench Boreholes, approximately two-thirds of the samples were classified as poorly graded sands with silt or well-graded sands with silt. Few samples contained significant amounts of clay or gravel. The soils were generally weakly-cemented to un-cemented. Silty sand predominated at borehole ST-3. Individual soil horizons were generally less than $1.5 \mathrm{~m}$ $(5 \mathrm{ft})$ thick, and the thickest layers were well-graded, fine grained material, alternating with thin layers of poorly-graded, coarse-grained materials. The layers were laterally discontinuous between boreholes spaced $15.25 \mathrm{~m} \mathrm{(50} \mathrm{ft)} \mathrm{apart.} \mathrm{In} \mathrm{some} \mathrm{cases} \mathrm{it} \mathrm{was} \mathrm{difficult} \mathrm{to} \mathrm{correlate}$ textural units between the augered borings and the ODEX borings drilled $1.5 \mathrm{~m}(5 \mathrm{ft})$ away. The discontinuous stratigraphy is consistent with deposition by sheet flood and channel flows on alluvial fans (REECo, 1993b).

The particle size distributions at the Science Trench Boreholes were very consistent with space and depth. The physical and hydrologic properties consequently were also similar. The researchers concluded the portion of the unsaturated alluvium penetrated by the Science Trench Boreholes was an approximately homogeneous hydrologic system (REECo, 1993b).

At the Pilot Wells, the particle size distribution of the alluvial materials did not vary greatly with depth, but were slightly coarser in texture than the very shallow alluvium from the soil trench study. The soil classifications are consistent with the middle to distal alluvial fan depositional environment. Sands with silt and silty sands predominate with thin intervals of gravels. These coarser grained intervals are probably not very laterally extensive, and may represent channel deposits as they shifted back and forth across the fan face and debris flows. Appendix E includes graphical profiles of soil textural classes logged for the cuttings from the borings. 
Characterization Report 92-Acre Area

Section: Site Characteristics

Revision: 0

Date: June 2006

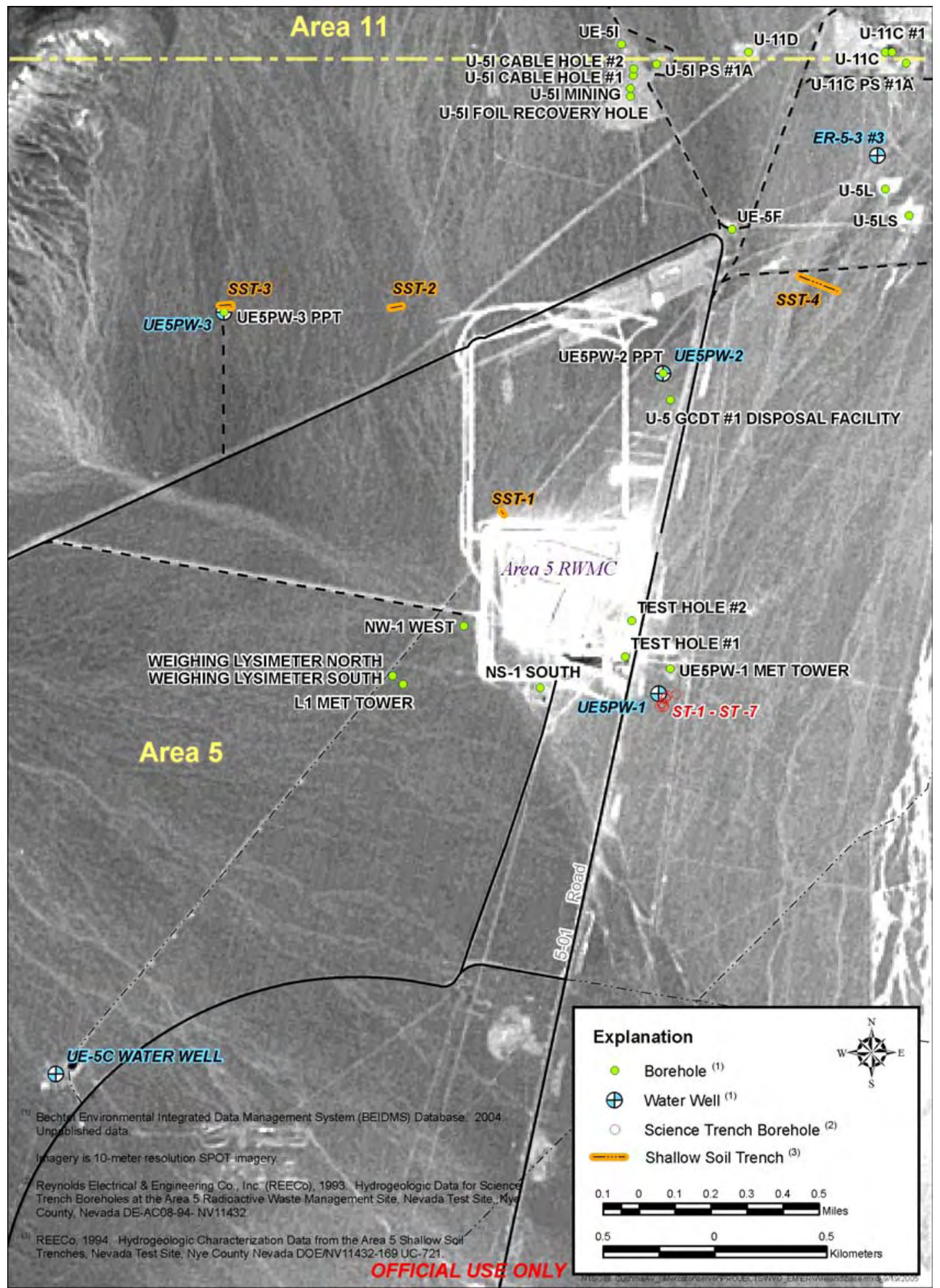

Figure 5-7. Locations of Borings, Trenches and Wells in the Vicinity of the Area 5 RWMS 
The unsaturated alluvium at UE5-PW-1 was very uniform. Percent silt and clay was generally less than 15 percent at UE5-PW-1, with mean percentages for core samples of 6.68 percent and cutting samples 7.24 percent. Sands and sands with silt predominate, with the occasional thin interval of silty sand. Very thin gravel layers were found at cuttings intervals approximately: 39.6-40.4 m, 77.7-78.5 m, and 184.4-185.2 m (130-132.5 ft, 255-257.5 ft, and 605-607.5 ft) below ground surface. These are unlikely to be laterally extensive based on the depositional environment and observations at the closely spaced Science Trench Boreholes. Hydrochloric acid reactions in the upper $61 \mathrm{~m}$ (200 ft) with few exceptions tended to be strong or moderate.

The unsaturated alluvium at UE5-PW-2 was a little more variable. Above the water table, percent silt and clay were generally less than 35 percent at Ue5-PW-2, with mean values for core samples of 11.08 percent and cuttings samples 12.82 percent. Sand with silt and silty sands predominate, with generally a little more silt than at Ue5-PW-1 or Ue5-PW-3. In the top

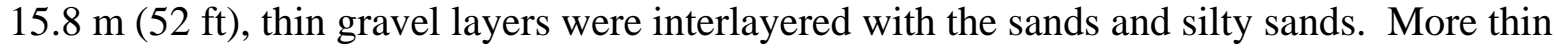
gravel lenses were encountered at PW-2 than PW-1, mainly below $122 \mathrm{~m}$ (400 ft) depth.

The unsaturated alluvium at UE5-PW-3 was very similar to UE5-PW-2. Percent of silt and clay was generally less than 22 percent at UE5-PW-3, with mean values for core samples of 9.59 percent and for cuttings samples 10.04 percent. Sands with silts and silty sands predominate. In the top $8.4 \mathrm{~m}(27.5 \mathrm{ft})$, thin gravel layers were interlayered with sands and silty sands. Thin gravel lenses were encountered at random intervals at greater depths. The contact with welded tuff was encountered at about $617 \mathrm{ft}(188 \mathrm{~m})$ depth. See BN, 2005e for further information.

\subsubsection{Mineral Composition and Geochemistry}

Mineral composition affects density, which affects how readily alluvial materials will erode. It can also affect soil water chemistry with sufficient residence times. The geochemistry of the native alluvium affects the transport of radionuclides by affecting their solubility and sorption characteristics. The alluvium is dominated by quartz, feldspar, and cristobalite, with calcite, gypsum, and minor amounts of clays and zeolites. Measured $\mathrm{pH}$ values range between 7 and 9, indicating neutral to alkaline conditions (Cochran, Beyeler, et al., 2001). The presence of clays and zeolites in an alkaline environment generally inhibit the mobility of most radionuclides. The geochemical environment of the closure cover is anticipated to be largely determined by the geochemistry of the constituent alluvium. The alluvium of the floors and walls of the disposal units is similar to the operational covers and very dry.

The alluvium at the shallow soil trenches was predominantly weakly cemented to cemented tuffaceous material at SST-2 and SST-3. Alluvium at SST-1 and part of SST-4 also included Paleozoic quartzite and limestone.

Similar to the shallow soil-trenches data, the alluvium at the Science Trench Boreholes was composed primarily of tuff, with occasional clasts of quartzite and limestone, and infrequently with basalt. Soils were generally weakly cemented to uncemented. The source area appears to be basic rhyolitic Tertiary volcanics from the Massachusetts Mountains. Inorganic carbon concentrations were low (mean less than 1 percent by weight) throughout the profile, suggesting 
there are no significant accumulations of cemented carbonate layers (caliche), which tend to have low porosities, and hydraulic conductivities that can slow percolation rates. Organic carbon content was also very low and uniform throughout the study area. (REECo, 1993b).

Analytical oxide and elemental composition data for the core samples from the pilot wells were very uniform. The native soils naturally contain small amounts of RCRA regulated metals from natural sources. There is very little secondary mineralization.

\subsubsection{Dry Bulk Density}

Bulk density is a parameter required for numerical models of fluid, heat, and solute transport. Mean dry bulk densities for various sets of cores from the shallow soil trenches varied from 1.55 to 1.70 grams per cubic centimeter $\left(\mathrm{g} / \mathrm{cm}^{3}\right)$ with coefficients of variance less than 7 percent. There were no consistent trends in bulk density with depth.

Similarly at the Science Trench Boreholes, there was significant uniformity of bulk density. Mean values of bulk density ranged from $1.527 \mathrm{~g} / \mathrm{cm}^{3}$ at ST-4 to $1.623 \mathrm{~g} / \mathrm{cm}^{3}$ at ST-7 with coefficients of variation of 7.3 percent or less. However plots of bulk density and porosity versus depth for ST-1, ST-2, ST-4, and ST-6 showed a slight increase in bulk density and slight decrease in porosity in the upper $20 \mathrm{ft}$ of these boreholes (REECo, 1993b).

Mean dry bulk densities of core samples from Ue5PW-1, Ue5PW-2, and UE5PW-3 were $1.64 \mathrm{~g} / \mathrm{cm}^{3}, 1.64 \mathrm{~g} / \mathrm{cm}^{3}$, and $1.66 \mathrm{~g} / \mathrm{cm}^{3}$ respectively (BN, 2005e). These values are only slightly higher than the average dry bulk density of the compacted operational covers on the landfills. Coefficient of variance was less than 10 percent. There are no consistent trends with depth. This fits with the overall consistency in particle size distributions and lithologies, and the lack of much cementation.

\subsubsection{Porosity}

Porosity (saturated volumetric water content) is a parameter required for modeling fluid, heat, and solute transport. It can be computed using measured saturated porosities and bulk densities.

Porosities were calculated from dry bulk densities for the shallow soil trench cores. Mean porosity for various sample sets varied from 36.0 percent to 41.7 percent with variances 10.5 percent and less.

Plots of porosity and bulk density versus depth for Science Trench Boreholes ST-1, ST-2, ST-4, and ST-6 showed a slight decrease in porosity and slight increase in bulk density in the upper $20 \mathrm{ft}$ of these boreholes. However, overall porosity was very uniform among the samples tested. Mean computed porosities ranged from 38.11 percent at ST-5 to 42.45 percent at ST-4 with coefficients of variation of less than 12 percent (REECo, 1993b).

For samples from the wells, water saturated porosities were less than porosities calculated from dry bulk densities partly due to drainage losses from coarse sample cores prior to measurement. Mean dry bulk densities and porosities from each well were very similar. Table 5-2 summarizes 
selected hydrological property data for core samples from the pilot wells, including the range and average porosity by well. Variances were low, indicative of the homogeneity of the alluvium.

Table 5-2. Hydrogeological Properties, Core Samples from Pilot Wells

\begin{tabular}{|c|c|c|c|c|c|c|c|c|c|c|c|c|}
\hline \multirow{2}{*}{$\begin{array}{l}\text { Property } \\
\text { (Units) }\end{array}$} & \multicolumn{3}{|c|}{$\begin{array}{l}\text { UE5PW-1 } \\
\text { Alluvium }\end{array}$} & \multicolumn{3}{|c|}{$\begin{array}{l}\text { UE5PW-2 } \\
\text { Alluvium }\end{array}$} & \multicolumn{3}{|c|}{$\begin{array}{l}\text { UE5PW-3 } \\
\text { Alluvium }\end{array}$} & \multicolumn{3}{|c|}{$\begin{array}{c}\text { UE5PW-3 } \\
\text { Tuff }\end{array}$} \\
\hline & Min & Max & Mean & Min & Max & Mean & Min & Max & Mean & Min & $\operatorname{Max}$ & Mean \\
\hline $\begin{array}{l}\text { Ksat } \\
\text { (centimeters } \\
\text { per second) }\end{array}$ & $\begin{array}{l}1.4 \mathrm{E}- \\
6\end{array}$ & $\begin{array}{l}5.8 \mathrm{E}- \\
3\end{array}$ & $\begin{array}{l}1.7 \mathrm{E}- \\
3\end{array}$ & $\begin{array}{l}2.1 \mathrm{E}- \\
6\end{array}$ & $\begin{array}{l}4.0 \mathrm{E}- \\
3\end{array}$ & $\begin{array}{l}5.7 \mathrm{E}- \\
4\end{array}$ & $\begin{array}{l}5.6 \mathrm{E}- \\
6\end{array}$ & $\begin{array}{l}3.2 \mathrm{E}- \\
3\end{array}$ & $\begin{array}{l}1.1 \mathrm{E}- \\
3\end{array}$ & $\begin{array}{l}6.0 \mathrm{E}- \\
7\end{array}$ & $\begin{array}{l}2.7 \mathrm{E}- \\
5\end{array}$ & $\begin{array}{l}1.4 \mathrm{E}- \\
6\end{array}$ \\
\hline $\begin{array}{l}\text { Gravimetric } \\
\text { Water } \\
\text { Content (\%) }\end{array}$ & 2.6 & 13.9 & 6.6 & 2.0 & 12.2 & 6.5 & 1.5 & 8.4 & 4.9 & 0.8 & 7.6 & 5.0 \\
\hline $\begin{array}{l}\text { Volumetric } \\
\text { Water } \\
\text { Content (\%) }\end{array}$ & 5.6 & 23.0 & 11.1 & 7.3 & 21.0 & 10.9 & 2.6 & 13.2 & 7.9 & 14.9 & 15.1 & 15.0 \\
\hline $\begin{array}{l}\text { Calculated } \\
\text { Porosity (\%) }\end{array}$ & 27.53 & 55.85 & 37.93 & 29.81 & 56.60 & 38.79 & 26.04 & 50.94 & 37.27 & 21.90 & 23.10 & 22.40 \\
\hline $\begin{array}{l}\text { Saturated } \\
\text { Porosity (\%) }\end{array}$ & 27.50 & 39.20 & 33.50 & 27.93 & 39.77 & 32.70 & 26.88 & 35.87 & 30.31 & - & - & - \\
\hline $\begin{array}{l}\text { Water } \\
\text { Potential } \\
\text { (bars) }\end{array}$ & -81.5 & -0.03 & -9.0 & -86.6 & -0.3 & -14.5 & $\begin{array}{l}-374 . \\
8\end{array}$ & -6.8 & -39.1 & $\begin{array}{l}-23.2 \\
\text { cores }\end{array}$ & $\begin{array}{l}-16.3 \\
\text { cores }\end{array}$ & $\begin{array}{l}-19.8 \\
\text { cores }\end{array}$ \\
\hline $\begin{array}{l}\text { Water } \\
\text { Potential } \\
\text { below } 150 \mathrm{ft} \\
\text { (bars) }\end{array}$ & -21.8 & -0.03 & -5.6 & -24.0 & -0.3 & -9.0 & - & - & - & - & - & - \\
\hline $\begin{array}{l}\text { Water } \\
\text { Potential } \\
\text { below } 100 \mathrm{ft} \\
\text { (bars) }\end{array}$ & - & - & - & - & - & - & -19.8 & -6.8 & -13.3 & - & - & - \\
\hline NOTES: & & & & & & & & & & & & \\
\hline $\begin{array}{l}\text { Except for wate } \\
\text { the cores from } \\
\text { See BN, } 2005 \text { e }\end{array}$ & $\begin{array}{l}\text { tential, } \\
\text { ve the v } \\
\text { comple }\end{array}$ & $\begin{array}{l}\text { ese rest } \\
\text { er table } \\
\text { data set }\end{array}$ & are for & alyses & $\begin{array}{l}\text { only the } \\
\text { limitatic }\end{array}$ & ore sam & s. The & uvium v & er con & summ & data a & or only \\
\hline
\end{tabular}

\subsubsection{Saturated Hydraulic Conductivity}

For cores from the shallow soil trenches, Ksat values ranges from $1.3 \mathrm{E}-05$ to 1.8E-02 centimeters/second $(\mathrm{cm} / \mathrm{sec})$ with means for various sample sets ranging from 5.8E-04 to $3.1 \mathrm{E}-03 \mathrm{~cm} / \mathrm{sec}$ and coefficients of variation from 106 to 261 percent. The finer textured upper parts of SST-1 and SST-3 were less permeable, but there were no obvious trends in Ksat with depth at the shallow trenches, and Ksat values were typical of silty sand alluvial deposits (Page 3-19, BN, 2005g).

At the Science Trench Boreholes, measured Ksat values ranged from 1E-05 to $4.9 \mathrm{E}-03 \mathrm{~cm} / \mathrm{sec}$. Mean values at each borehole ranged from $2.91 \mathrm{E}-04 \mathrm{~cm} / \mathrm{sec}$ at ST-4 to $9.89 \mathrm{E}-04 \mathrm{~cm} / \mathrm{sec}$ at ST-6. There were no apparent trends with depth (REECo, 1993b). 
Saturated hydraulic conductivities were obtained from tests on three in-core samples from the pilot wells. Hydraulic conductivities ranged from $1.4 \mathrm{E}-06$ to $5.8 \mathrm{E}-03 \mathrm{~cm} / \mathrm{sec}(\mathrm{BN}, 2005 \mathrm{e})$. The report noted that there were no obvious trends as a function of depth and that these values are typical of silty sand alluvial deposits (BN, 2005b). Table 4 includes the range and average Ksat values for core samples analyzed from each well.

\subsubsection{Water Potential, Water Characteristic Curves, and Unsaturated Hydraulic Conductivity}

Water potential differences help drive the movement of water. Water potential is related to water content by water characteristic curves. The highest potential flow rates are under saturated conditions. At lower moisture levels, the geometry of the small pores, viscosity, surface tension, and other factors increase in importance. Trapped air and vapor in the pores also affects the potential for water movement. Water movement rates in unsaturated conditions are significantly slower than in saturated conditions. Soil moisture retention data are used to estimate unsaturated hydraulic activity for arid soil with low water contents.

Plots of water potential versus volumetric water content for core samples from Science Trench Boreholes ST-1 and ST-4 showed similar relationships for all of the cores. The range in fitted van Genuchten parameters was small. The van Genuchten parameters for the water characteristic curve data were similar to the values found for individual fine and coarse layers in the existing excavations study. Mean residual water contents ( $\Theta r$ ) for data from all core samples was $0.511 \mathrm{~cm} 3 / \mathrm{cm} 3$, mean saturated water contents $(\Theta \mathrm{s})$ was $0.363 \mathrm{~cm} 3 / \mathrm{cm} 3$, mean shape parameter $(\alpha)$ was $0.041 \mathrm{~cm}-1$, and mean shape parameter (n) was 0.456 (REECo, 1993b).

Plots of computed unsaturated conductivity functions versus volumetric water content for core samples from the Science Trench Boreholes show that in the vicinity of the Area 5 RWMS, unsaturated hydraulic conductivities decrease sharply with decreasing water contents. As for the measured in situ soil moisture contents, the unsaturated hydraulic conductivity is 5 to 20 orders of magnitude less than Ksat (REECo, 1993b).

The pilot well data are very similar. Moisture retention curves and fitted unsaturated hydraulic conductivity functions for core samples from the pilot wells are presented in the revised REECo pilot wells report (BN, 2005e) and in the PA (Shott et al., 1998). The van Genuchten parameters for the water characteristic (moisture retention) curve data varied slightly between wells, but the average values for all the cores collected from the wells were similar orders of magnitude to those found at the Science Trench Boreholes.

At the pilot wells, depth profiles of water potential indicated a positive gradient (an upward movement of liquid) to at least a depth of $30.5 \mathrm{~m}(100 \mathrm{ft})$ in each borehole. At greater depths, the water potential gradient is nearly zero, indicating that gravity is the main driver of liquid water movement through that zone. Below about $45.7 \mathrm{~m}(150 \mathrm{ft})$ there is no upward flux. Table 4 presents selected summary statistics including mean water potential values for the cores samples for each well as a whole and for the deeper samples from each well. For further detail see the report by BN (2005e). 
Data implies that travel rates are slow for water transport through the upper vadose zone. Calculation of the unsaturated hydraulic conductivity for a mean water content of 11.2 percent at Ue5PW-1 was less than $1 \mathrm{E}-07 \mathrm{~cm} / \mathrm{sec}$ for all cases. The median unsaturated hydraulic conductivity curve was about $1 \mathrm{E}-09 \mathrm{~cm} / \mathrm{sec}$. Assuming a water filled porosity of 10 percent, the average flux (in the deeper alluvium below the zone of positive water potential) is equivalent to a water travel rate of about 3E-03 m/year (or $1 \mathrm{E}-02 \mathrm{ft} /$ year). It would take 1,000 years for water to travel $3 \mathrm{~m}$ (10 ft) (p. 3-51 BN, 2005e).

\subsubsection{Tritium Transport in Soil Gas}

Monitoring of tritium concentrations in soil gas at multiple depths over time provides key data for evaluating the rate of vertical migration of radionuclides. Gas-phase tritium monitoring has been conducted via soil-gas sampling at GCD-05U (Figure 2-1) since 1990. This disposal unit has a large tritium inventory (2.2 million $\mathrm{Ci}$ at time of disposal) and is instrumented with two strings of nine soil-gas sampling ports buried at depths ranging from 3 to $37 \mathrm{~m}$ (10 to $120 \mathrm{ft}$ ) below surface. Tritium sampling at GCD-05U provides a direct measure of tritium migration from waste packages with time due to degradation of waste containers and the natural transport processes of advection and diffusion. Figure 5-8 shows the soil-gas tritium concentrations at GCD-05U at each sampling depth over time. Results from 1990 through 2004 indicate that soil-gas tritium concentrations have gradually increased at depths between 15 and $37 \mathrm{~m}$ (50 and $120 \mathrm{ft}$ ), but vertical migration is extremely slow.

Soil-gas sampling ports have been installed at other locations at the Area 5 RWMS, including beneath pits P03U and P05U. The ports are not currently monitored.

\subsubsection{Environmental Tracers}

Environmental tracers provide a way to estimate vadose-zone water movement, travel times, and recharge. Infiltrating precipitation and runoff carry conservative, non-sorbing materials that can be tracers for water as it percolates through the vadose zone. Tracer data were collected and evaluated from the Science Trench Boreholes and the pilot wells.

\subsubsection{Chloride and Bromide}

Chloride and bromide are deposited as water moving through the soil evaporates. At the Science Trench Boreholes, plots of concentrations versus depth indicate chloride levels were high throughout the $36.5 \mathrm{~m}(120 \mathrm{ft})$ depth, but there was a significant increasing trend upward through

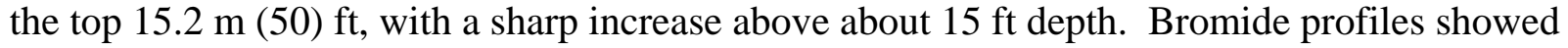
similar trends, with gradual increases through the top $15.25 \mathrm{~m} \mathrm{(50} \mathrm{ft)} \mathrm{and} \mathrm{a} \mathrm{prominent} \mathrm{increase} \mathrm{in}$ the top about $4.5 \mathrm{~m}$ (15 ft) of each boring. The data are consistent with other data indicating high evaporation rates and an upward water potential gradient in the shallow alluvium (REECo, 1993b). 
Characterization Report 92-Acre Area

Section: Site Characteristics

Revision: 0

Date: June 2006
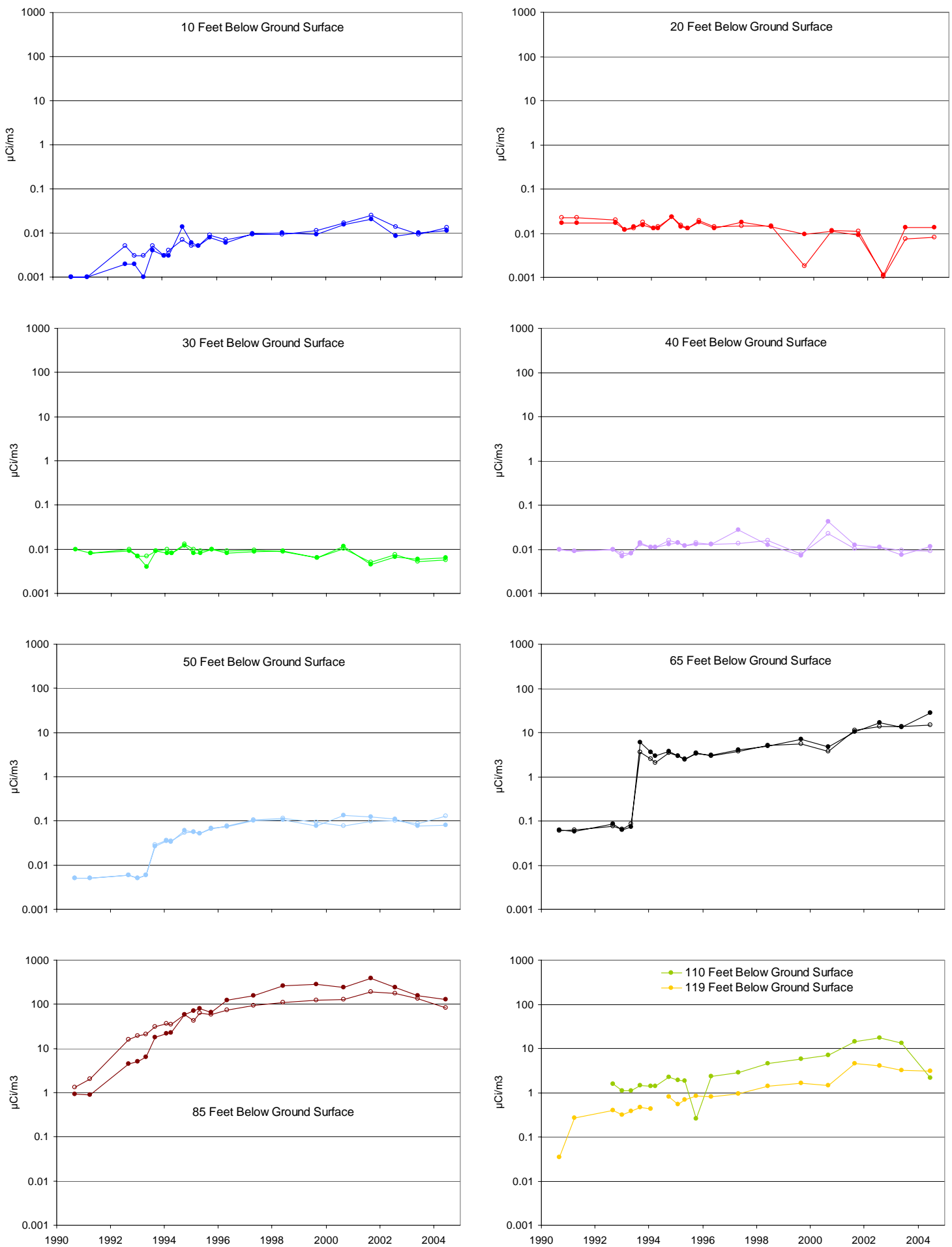

Figure 5-8. Soil Gas Tritium Concentrations at Each Sampling Depth Over Time, 1990-2004

Source: NTS 2004 Waste Management Monitoring Report (BN, 2005c) 
At the pilot wells, the chloride distribution data also supports the water potential observations. Evaporation appears to be occurring in at least the upper $30.5 \mathrm{~m}$ (100 ft). Chloride and bromide concentrations were very low and approximately constant below about $76.2 \mathrm{~m}(250 \mathrm{ft})$ in UE5PW-1, $30.5 \mathrm{~m} \mathrm{(100} \mathrm{ft)} \mathrm{at} \mathrm{UE5PW-2} \mathrm{and} 121.9 \mathrm{~m}$ (400 ft) at UE5PW-3. Relatively high concentrations were found in the shallow subsurface indicative of high evaporation rates. The Bromide concentration profiles were very similar (BN, 2005e).

\subsubsection{Sulfate}

Sulfate is a less soluble and less mobile tracer than chloride and bromide. In the upper $9.1 \mathrm{~m}$ (30 ft) of the Science Trench Boreholes, the concentrations of sulfate were high and very variable, with a gradual decrease in concentrations between $9.1 \mathrm{~m}(30 \mathrm{ft})$ and $36.5 \mathrm{~m}(120 \mathrm{ft})$. The variability in the uppermost $9.1 \mathrm{~m}$ ( $30 \mathrm{ft}$ ) may be due to sulfate mineral deposits (e.g., gypsum). The amount of adsorbed sulfate on soil colloids is small compared to soluble sulfates, which is consistent with the small amounts of clay in the alluvium (REECo, 1993b, p.78).

Sulfate concentration profiles show high and variable sulfate present in the top $60 \mathrm{~m}(197 \mathrm{ft})$ at well UE5PW-2 and $80 \mathrm{~m}$ (262 ft) at well UE5PW-3. At greater depths, concentrations were low and more consistent. Analysis for this tracer was added to the suite after work had already begun at UE5PW-1, so there is not a complete data set for that well (BN, 2005b).

\subsubsection{Stable Isotopes of Hydrogen and Oxygen}

Hydrogen and oxygen tracers are part of the water molecules themselves. Evaporation of rainwater results in a preferential reduction in the light end stable isotopes and concentration of high end stable isotopes. Hydrogen and deuterium ratios for soil moisture samples analyzed from the Area 5 RWMS studies fall below the meteoric water line. At both the Science Trench Boreholes and at the pilot wells, the researchers found enrichment in heavy isotopes in the upper vadose zone suggesting that the shallow soil water has been subject to more evaporation. See REECo (1993b).

Plots of the isotopes with depth at the Science Trench Boreholes for cores from borings ST-1, ST-2, and ST-4 indicate there is a gradual increase in deuterium and oxygen-18 from the deepest samples collected from about $36.6 \mathrm{~m}(120 \mathrm{ft})$ depth to the shallowest samples analyzed, from about $3 \mathrm{~m}$ (10 ft) depth. An increase in the rate occurs somewhere between $21.3 \mathrm{~m}$ and $18.3 \mathrm{~m}$ (70 and $60 \mathrm{ft}$ ) depth, and another increase in the rate occurs above $6.1 \mathrm{~m}$ (20 ft) depth. These trends correlate well with chloride and bromide data.

\subsubsection{Chlorine-36}

Chlorine-36 $\left({ }^{36} \mathrm{Cl}\right)$ and stable chlorine profile data were collected to evaluate relative age of soil water. The ${ }^{36} \mathrm{Cl}$ is produced naturally in the atmosphere. More ${ }^{36} \mathrm{Cl}$ is thought to be produced during geomagnetic fluctuations. The most recent geomagnetic fluctuation is thought to have occurred 15,000 to 25,000 years ago, and elevated ratios have been found in 21,000 year old pack rat middens (Phillips et al., 1988 as cited in BN, 2005e). Nuclear weapons tests in the South Pacific produced a spike in atmospheric levels of ${ }^{36} \mathrm{Cl}$ from 1952 to 1964 (BN, 2005g). At 
both the Science Trench Boreholes and Pilot Wells, the ratios of ${ }^{36} \mathrm{Cl}$ :Cl found in samples above

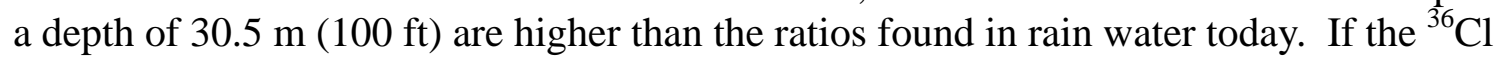
enrichment in the soil water at $100 \mathrm{ft}$ is primarily due to age, the downward percolation of water through the near-surface vadose zone is extremely slow. This finding appears to be consistent with the hydraulic parameter data and environmental tracer data.

The scientists concluded that these environmental tracer profiles imply that in the present arid climate, the portion of the precipitation that infiltrates does not move very far into the upper vadose zone, due to evaporation. The soil water present in the lower vadose zone infiltrated thousands of years ago under a more humid climate when evaporation demand was much lower (BN, 2005e).

\subsubsection{Vadose Zone Water Balance Monitoring}

Vadose-zone monitoring is conducted at the Area 5 RWMS to support hydrogeologic characterization, to demonstrate compliance with DOE Orders 450.1 and 435.1, and to monitor performance. Near-surface soil-moisture levels have been monitored in the past by neutron logging surveys. The TDR data from automated waste cover monitoring systems provide direct measurement of moisture fluxes. Water-balance changes in the vadose zone are evaluated using meteorology data to calculate PET; direct measurements of actual evapotranspiration, and bare-soil evaporation at the Area 5 RWMS weighing lysimeter facility; and measured fluxes of soil-water content and soil-water potential in waste cell covers and floors from an automated waste-cover monitoring system. Figure 5-2 shows the location of automated vadose-zone stations collecting data from the moisture and temperature sensors installed in floors and covers of selected pits. Figure 5-9 shows the locations of the groundwater monitoring wells and the weighing lysimeters.

As a result of this extensive characterization and monitoring work, there is an excellent understanding of vadose-zone processes and characteristics in the vicinity of the Area 5 RWMS, and a strong conceptual model of water and vapor transport, which enhances our understanding of the potential for contaminant transport.

\subsubsection{Soil Moisture Monitoring}

\section{Neutron Logging}

Neutron logging historically was conducted at selected neutron access tubes at the Area 5 RWMS to provide profiles of soil-water content with depth and time. Automated TDR systems have replaced neutron logging at the Area 5 RWMS. For a detailed history of the neutron logging monitoring program at the Area 5 RWMS, refer to BN (1997). Figure 5-9 shows the approximate locations of access tubes. There are access tubes in the east end of the operationally closed portion of P03U MWDU, and in the operational covers of P01U, P02U, P04U, and P05U. There are also a few access tubes around the perimeter of the 92-Acre Area. The neutron access tubes are anticipated to remain in the operational covers and most should be accessible until the final landfill cover is emplaced. 


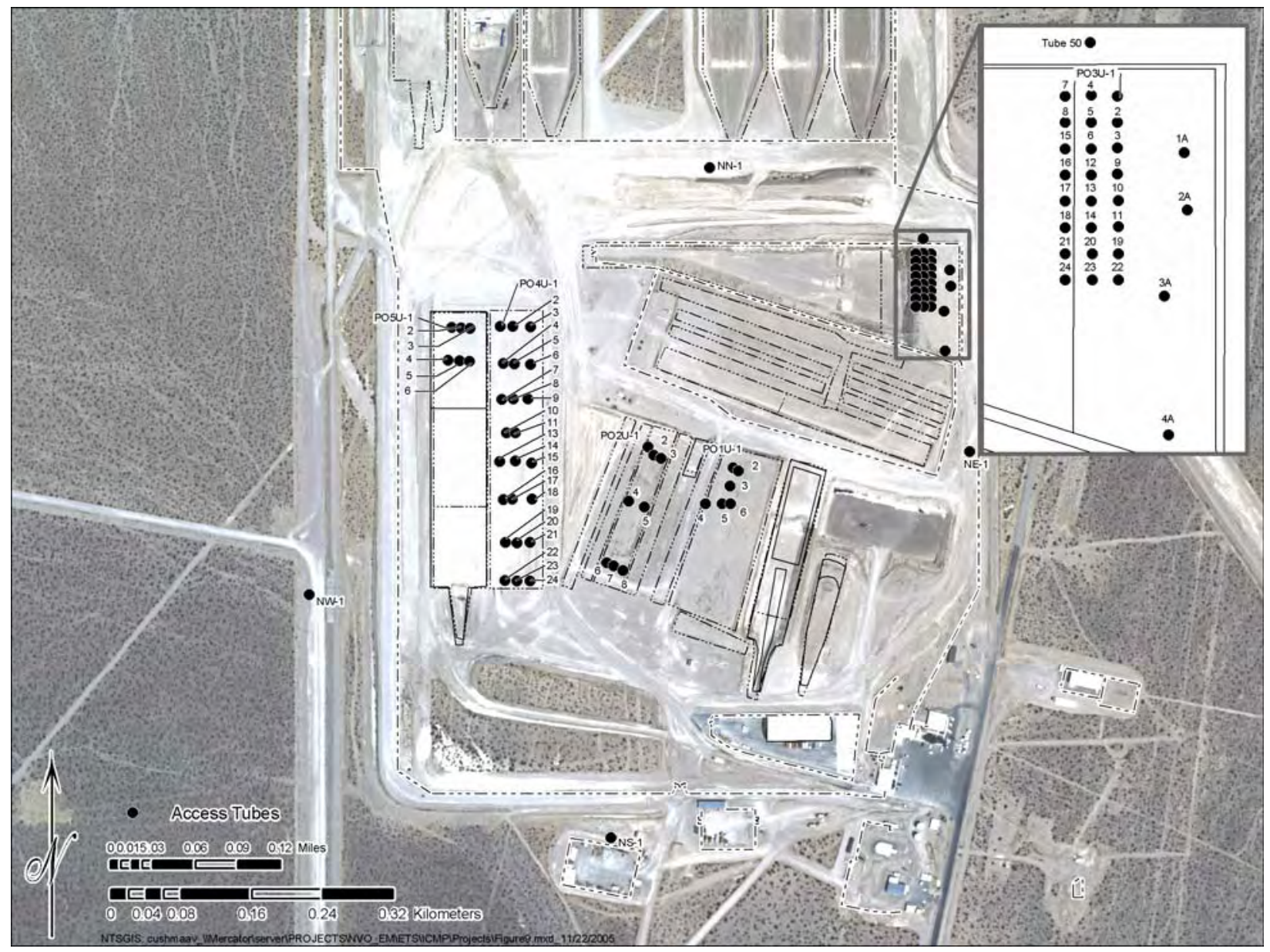

Figure 5-9. Locations of Neutron Probe Access Tubes

The Neutron Probe Calibration Facility south of pilot well Ue5PW-1 (Figure 5-2) was equipped in 1998 with TDR probes around each type of casing used for neutron probe access ports. The TDRs are buried at depths of 30,60, and $90 \mathrm{~cm}(1,2$, and $3 \mathrm{ft})$.

\section{Automated Monitoring System Data}

In 1998, TDR probes were installed at depths of $0.3,0.6$, and $1.2 \mathrm{~m}(1,2$, and $4 \mathrm{ft})$ at the north

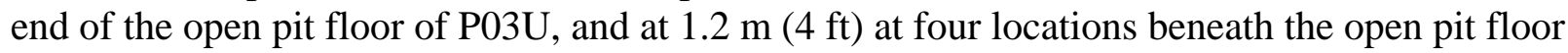
of P05U at the Area 5 RWMS. Waste was deposited above the probes (BN, 2005c). In January 2002, the station and probes in the floor of Pit 3 were removed to accommodate waste operations. The station was near a pit edge requiring earth work (Personal Communication, D. Rudolph, November 22, 2005).

The Pit 5 North (Pit5N) floor sensors include CS 610 TDRs approximately 16 and 28 m (52.5 and $92 \mathrm{ft}$ ) west of the Pit5N station which is on the edge of Pit 4 (Figure 5-2) and CS615 reflectometers located approximately 16, 28, and $42 \mathrm{~m}$ (52.5, 92, and $138 \mathrm{ft})$ west of the Pit5N

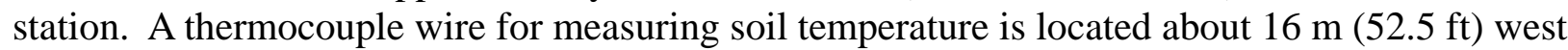
of these stations. All of these sensors are buried about $1.2 \mathrm{~m}(4 \mathrm{ft})$ below the floor. The Pit 5 
South (Pit5S) floor TDR and reflectometer array is similar to Pit5N. (Personal Communication, D. Rudolph, November 22, 2005). The south floor sensors are monitored at the Pit5S vadosezone station which is located on the operational cover of P04U (Figure 5-2). A gas-sampling port with a stainless steel tube was also installed for each station.

Measured volumetric soil water content at the P03U and P05U floor sensors has consistently

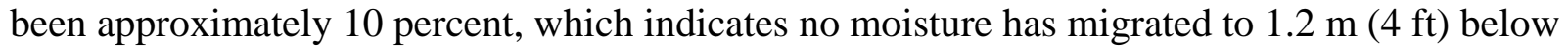
the waste during the respective periods of record, December 1998-2002 and

December 1998-December 2004 (BN, 2005c). Because the likelihood of infiltrated storm water ever reaching pit floor sensors after emplacement of waste and the operational covers is negligible (based on monitoring of moisture in operational covers), no further instrumentation of the pit floors at the Area 5 RWMS is currently planned. Water balance data from the lysimeter studies, and performance modeling is discussed in later sections of this report.

Automated monitoring of moisture in operational soil covers has also been implemented at three unclassified pits. In 1999, nests of TDR probes were installed in the operational cover of Pit 3 (P03U) at two sites (north and south), at depths ranging from 10 to $180 \mathrm{~cm}$ (0.3 to $5.9 \mathrm{ft}$ ), and in 2000, in the operational covers of Pits 4 and 5 (P04U and P05U) at depths ranging from 15 to $180 \mathrm{~cm}$ ( 0.5 to $5.9 \mathrm{ft})$. Heat dissipation probes, which are essentially water potential and temperature sensors, were installed in the operational covers of P05U and P04U at similar depths as the TDRs, ranging from 15 to $180 \mathrm{~cm}(0.5$ to $5.9 \mathrm{ft})$. The sensors are connected to dataloggers at the vadose zone stations shown in Figure 5-2. Telemetry for remote downloading of data by telephone has been installed at some stations.

Past monitoring reports (e.g., BN, 2002c) noted that moisture percolation through the soil covers rarely exceeded $60 \mathrm{~cm}(2 \mathrm{ft})$ depth. However, during a relatively wet fall season in 2004, precipitation percolated to slightly greater depths at all three of the monitored Area 5 unvegetated operational landfill covers. At P03U, water percolated past a depth of $120 \mathrm{~cm}(3.9 \mathrm{ft})$ at the north TDR nest location and past a depth of $150 \mathrm{~cm}(4.9 \mathrm{ft})$ at the south nest location. Fall 2004 precipitation percolated more than $120 \mathrm{~cm}(3.9 \mathrm{ft})$ in the cover of P04U, and deeper than $60 \mathrm{~cm}$ (2 ft) at P05U. See the 2004 Waste Management Monitoring Report (BN, 2005c) for further information. These depths are very shallow compared to the extent of the zone of upward water movement indicated by tracer and water potential data.

\subsubsection{Area 5 Weighing Lysimeter Facility Evapotranspiration, Evaporation, and Storage Data}

The Area 5 Weighing Lysimeter Facility consists of two precision weighing lysimeters located about $400 \mathrm{~m}$ (1,312 ft) southwest of the Area 5 RWMS (Figure 5-10). Each lysimeter consists of a steel box $2 \mathrm{~m}(6.6 \mathrm{ft})$ deep, filled with soil and having a ground-surface area of $2 \mathrm{by} 4 \mathrm{~m}$ (6.6 by $13 \mathrm{ft}$ ) and a volume of $16 \mathrm{~m}^{3}\left(565 \mathrm{ft}^{3}\right)$. The top of the soil tank is flush with the ground surface, and access to the side of the soil tank is provided through an underground entry. Each lysimeter is mounted on a sensitive scale, which is continuously monitored using an electronic loadcell. 


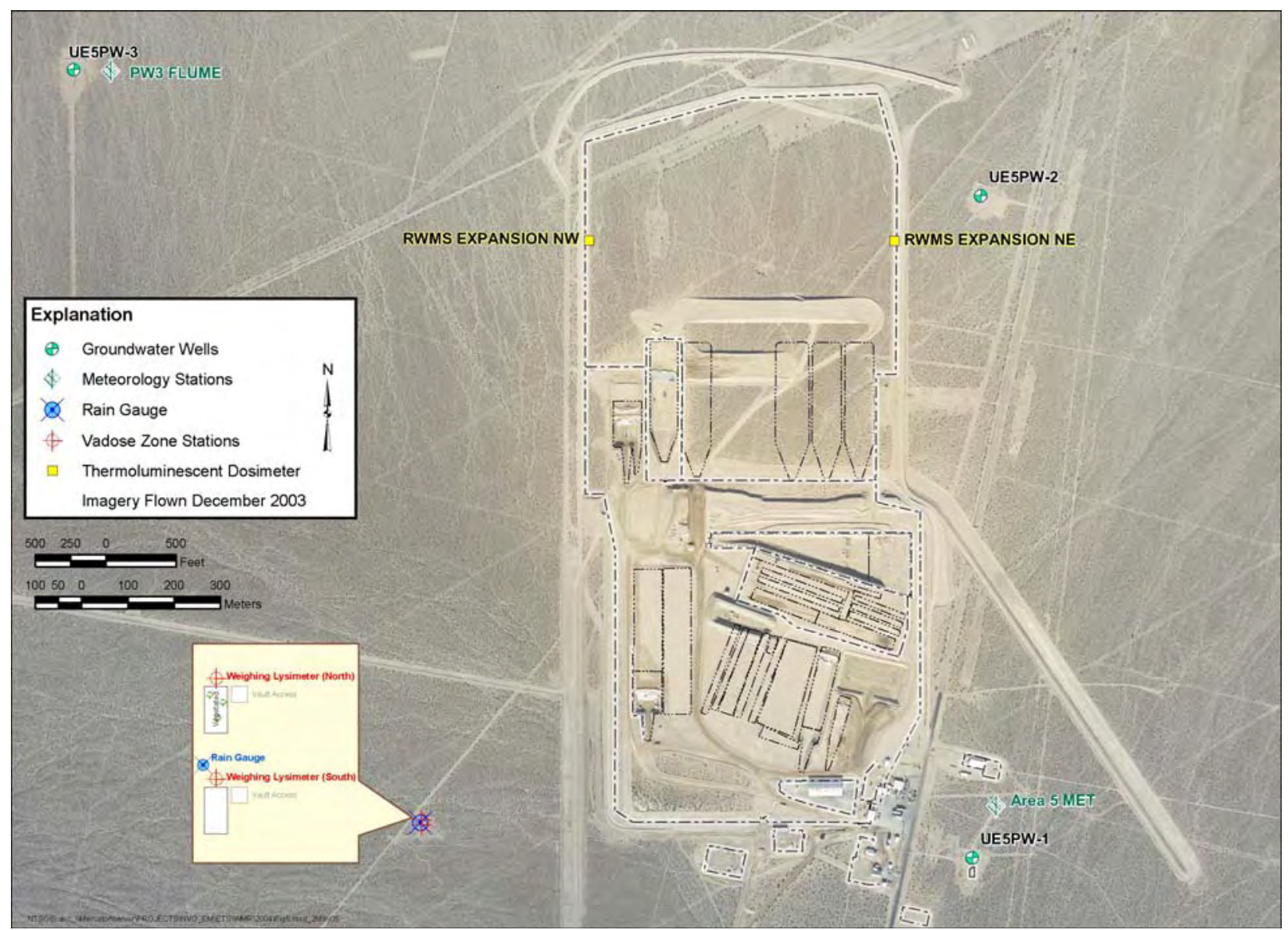

Figure 5-10. Locations of the Area 5 RWMS Pilot Wells and Weighing Lysimeter Facility

One lysimeter is vegetated with native plant species at the approximate density of the surrounding desert. The other is kept bare, to simulate the bare operational waste covers at the Area 5 RWMS. Each of the weighing lysimeters is instrumented with TDR probes to measure volumetric soil-water content at depths ranging from 10 to $170 \mathrm{~cm}$ (4 to $67 \mathrm{in}$ ). The TDR probes are connected to automated datalogger systems that provide daily profiles of soil-water content. The loadcells have been monitored continuously since March 1994 and provide an accurate dataset of the surface water balance at the Area 5 RWMS. This monitoring time period also includes the wet "El Nino" year of 1998, when rainfall was twice the annual average. For details of the weighing lysimeters, refer to Levitt et al. (1996).

Weighing lysimeter data provide a simplified water balance: change in soil water storage is equal to precipitation minus evaporation or evapotranspiration. A 1-in- high lip around the edge of the lysimeters prevents run-on or runoff.

Total soil-water storage and daily precipitation totals are illustrated in Figure 5-11 for the period of March 30, 1994, through December 2004. The plants transplanted to the vegetated lysimeter initially required irrigation to become established. Soil-water storage data for the vegetated lysimeter for April 25, 1994, through November 18, 1994, reflects the additional artificial irrigation (Personal Communication, D. Hudson, September 6, 2005). 


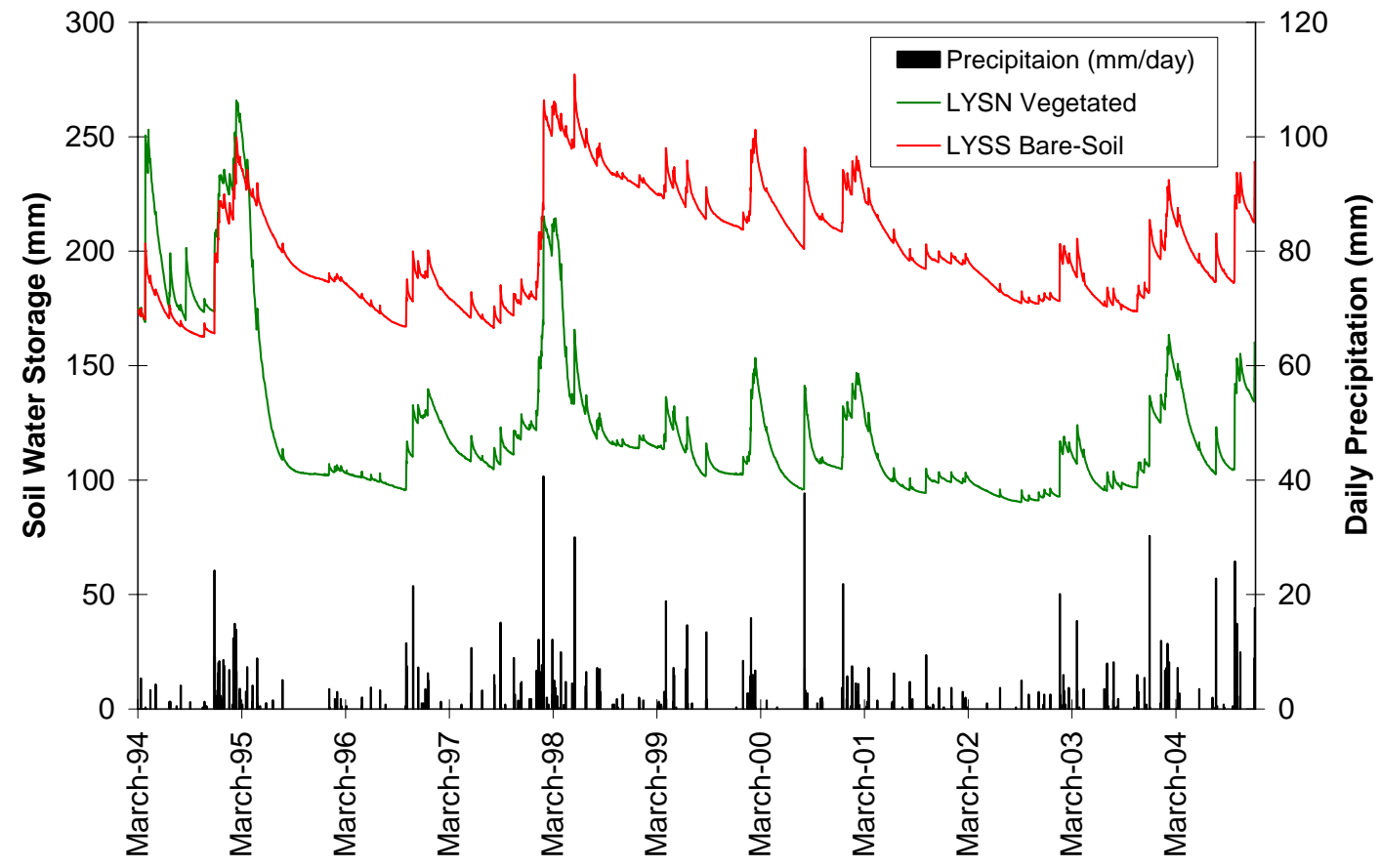

Figure 5-11. Soil Water Storage and Precipitation over Time, March 1994 through 2004

Source: 2004 Waste Management Report (BN, 2005c)

Although the vegetative cover is only about 15 percent of the area, the vegetated lysimeter is significantly drier than the bare-soil lysimeter, due to transpiration. The moisture storage at the vegetated lysimeter has never exceeded $1.2 \mathrm{~m}$ (4 ft) depth. However, in the spring of 2005, the moisture in the bare-soil lysimeter reached the base of the lysimeter at $2 \mathrm{~m}(6.6 \mathrm{ft})$ depth and water began to pond at the bottom. Eventually there may be some drainage out the bottom of the lysimeter. A conservative estimate is a flux of $1 \mathrm{~cm}(.4 \mathrm{in}) / \mathrm{yr}$ (L. Desotell, Personal Communication September 21, 2005).

Conservative modeling results also indicate that some slight drainage (1 percent of rainfall) will eventually leak from the bottom of the bare-soil lysimeter (Levitt et al., 1999). Although this suggests that a small amount of precipitation may eventually percolate through the operational waste covers of the trenches and pits to waste levels, given that average annual precipitation is $12.9 \mathrm{~cm}$ (5.08 in), there is little potential for production of leachate from the landfill. The thick vadose zone below the waste cells has low water potentials, low unsaturated hydraulic conductivity rates, and ample water storage capacity. Therefore, the potential for significant downward transmission of water, much less recharge, in the vicinity of the Area 5 RWMS, is extremely low in the absence of open boreholes or other conduits.

Figure 5-12 shows cumulative precipitation, evapotranspiration, and evaporation in 2004, the latest published year of record. Figure 5-13 shows monthly precipitation, evaporation, and evapotranspiration measured in the weighing lysimeters in 2004. The cumulative data suggest precipitation exceeded evapotranspiration rates in the spring and fall concurrent with peaks and rapid declines in storage. The monthly data show evapotranspiration and evaporation exceeded precipitation for 8 months in 2004. 
Characterization Report 92-Acre Area Section: Site Characteristics

Revision: 0

Date: June 2006

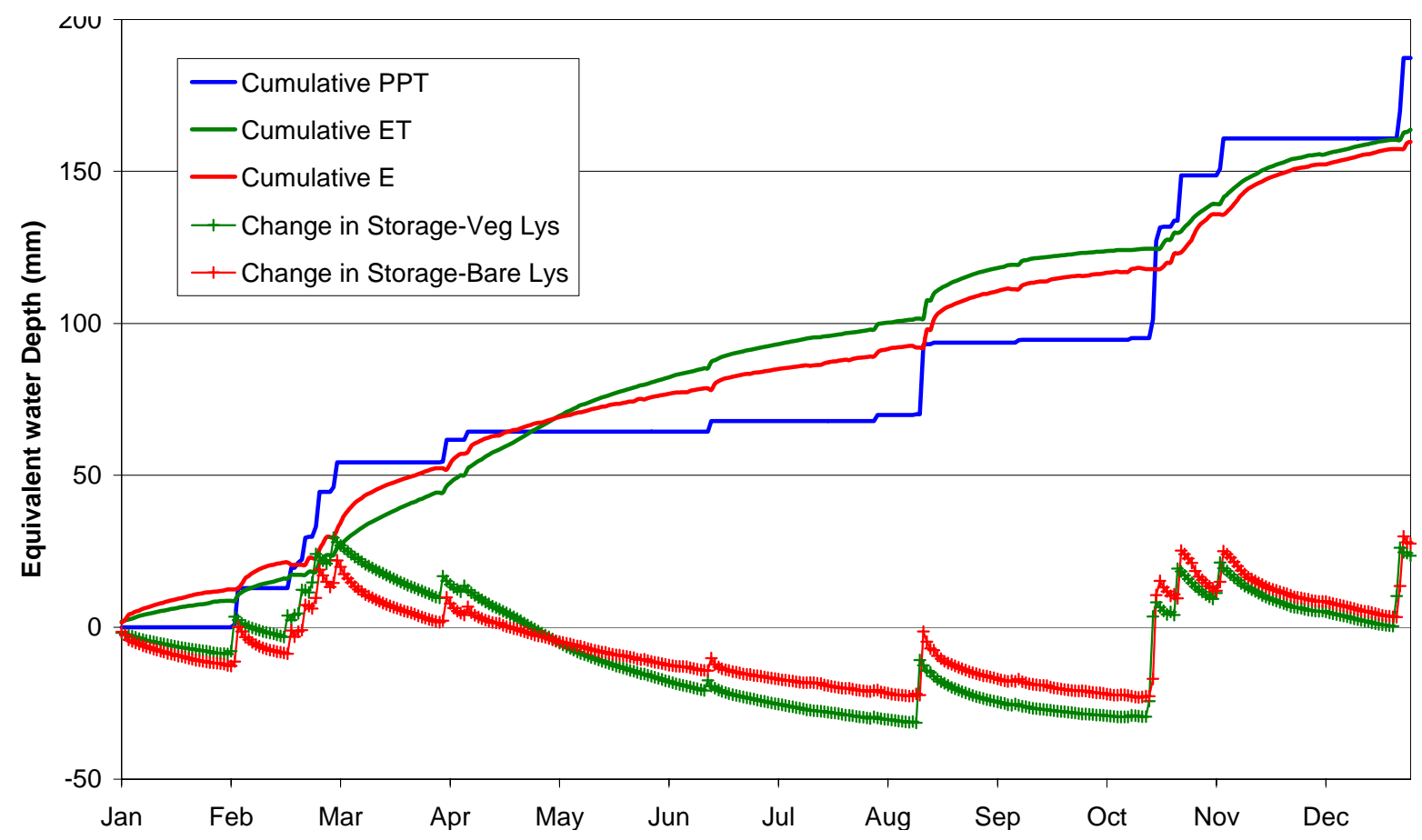

Figure 5-12. Cumulative Precipitation, Evapotranspiration, Evaporation, and Storage Change for Weighing Lysimeter in 2004

Source: 2004 Waste Management Report (BN, 2005c)

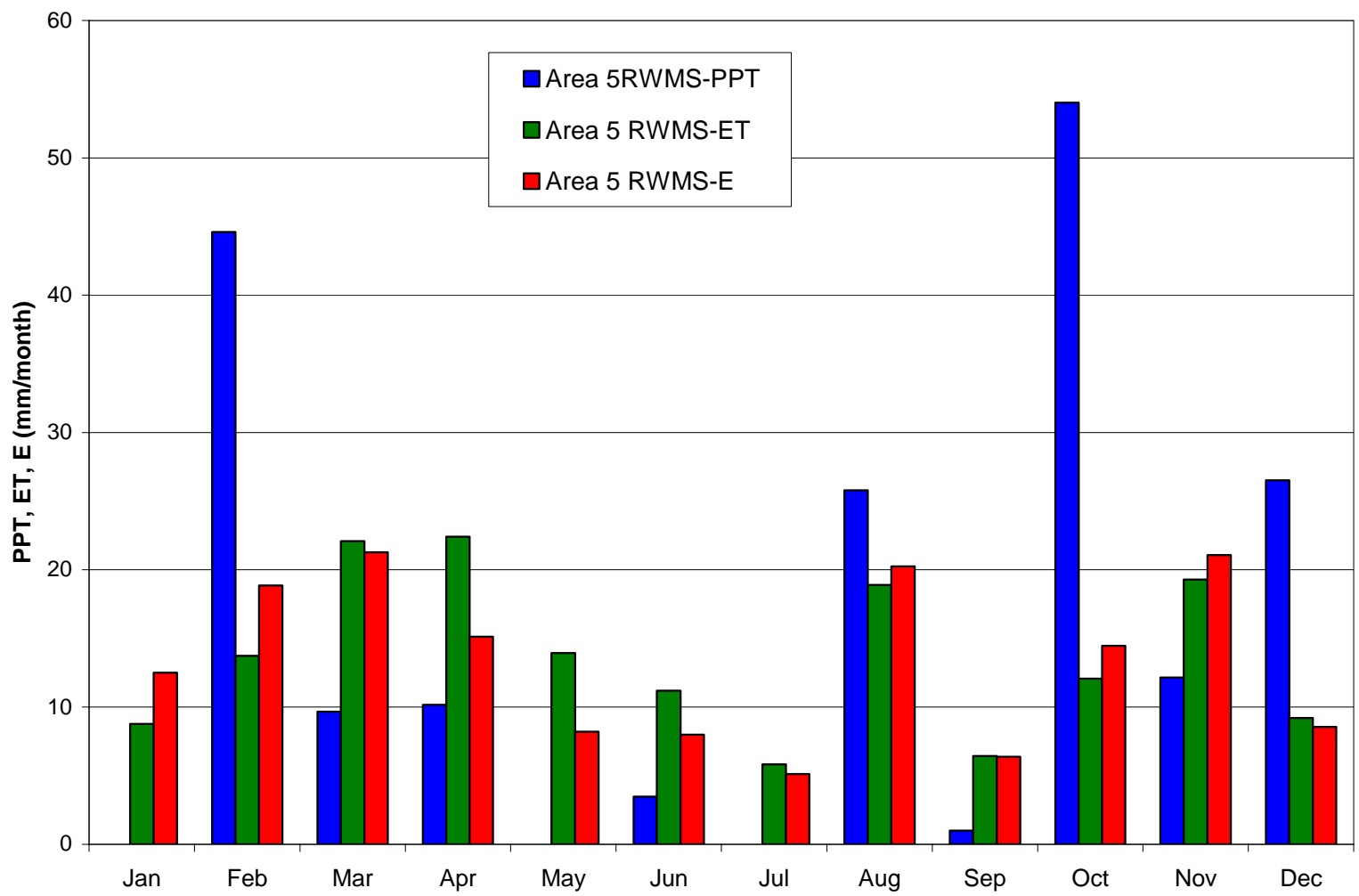

Figure 5-13. Monthly Precipitation, Evaporation, and Evapotranspiration Measured at Weighing Lysimeters in 2004.

Source: 2004 Waste Management Monitoring Report (BN, 2005c) 
Date: June 2006

\subsubsection{Key Findings}

Climate and vegetation strongly influence the movement of water in the near-surface alluvium (upper $2.0 \mathrm{~m}$ [6.5 ft]). Except for periods following precipitation events, water content in the near-surface region is low. Below this region is a zone where steady upward movement of water is occurring, primarily via evaporation (Tyler et al., 1996). This zone extends to depths as great as 3 to $40 \mathrm{~m}$ (10 to $131 \mathrm{ft}$ ) in Area 5. Below this zone, water potential measurements indicate the existence of a static zone between approximately 40 to $90 \mathrm{~m}$ (131 to $295 \mathrm{ft}$ ) below the ground surface in Area 5 (Shott et al., 1995; 1998). In this static zone, essentially no vertical liquid flow is currently occurring. Below this static zone, flow is downward, due to gravity.

Monitoring and modeling data for Area 5 have indicated conditions of zero recharge (Levitt et al., 1996; Shott et al., 1998). Recent studies show that under bare-soil conditions such as those at the Area 5 operational waste-cell covers, some drainage may occur through the covers and into the waste zone. Monitoring data from the Area 5 bare-soil weighing lysimeter indicate that in the spring of 2005 the infiltrated water reached a depth of $2 \mathrm{~m}(6.6 \mathrm{ft})$ and began to pond at the bottom of the lysimeter.

Climate and vegetation strongly control the movement of water in the upper $2 \mathrm{~m}(6 \mathrm{ft})$ of the alluvium. The magnitude and direction of both liquid and vapor fluxes vary seasonally and often daily. Except for periods following precipitation events, water contents in this near-surface region are low. Below the near-surface region is a region where relatively steady upward movement of water is occurring. In this region of slow upward water movement, stable isotope compositions of soil pore water show that evaporation is the dominant process (Tyler et al., 1996). This region extends to depths from approximately 3 to $49 \mathrm{~m}$ (10 to $160 \mathrm{ft}$ ) in Area 3, and from approximately 3 to $40 \mathrm{~m}$ (10 to $130 \mathrm{ft}$ ) in Area 5. Below this region, water potential measurements indicate the existence of a static region, which occurs between approximately 49 to $119 \mathrm{~m}$ (160 and $390 \mathrm{ft}$ ) in Area 3, and between approximately 40 to $90 \mathrm{~m}$ (131 and $295 \mathrm{ft}$ ) in Area 5 (Shott et al., 1998, 1997, 1995). In this static region, essentially no vertical liquid flow is currently occurring. Below this static region, flow is steady and downward, due to gravity.

A conceptual model of unsaturated zone processes is shown in Figure 5-14. Stable isotope compositions of pore water indicate that infiltration into the static region must have occurred under cooler, climate conditions in the past (Tyler et al., 1996). In the unlikely event contaminants were to migrate below the static region to the part of the aquifer where vertical flow by gravity is possible, movement to the groundwater would be extremely slow. Conservative median modeling estimates of the time it would take water to move from beneath the static region (about $90 \mathrm{~m}$ (98.4 yards) depth at pilot well UE5PW-1) to the groundwater (about $220 \mathrm{~m}$ [240.6 yards] depth) in Area 5 are in excess of 50,000 years (Shott et al., 1995 and 1998). Under the model assumptions there was a 99 percent probability that the travel time would exceed 30,000 years (Shott et al., 1998).

Based on the results of extensive research, field studies, modeling data, and monitoring data, which are summarized in the Area 5 RWMS PAs (Shott et al., 1998, 1995) and in Levitt et al. (1998), there is no aerially distributed groundwater recharge under current climatic conditions at the RWMS. Recent studies indicate that under bare-soil conditions such as those found at the operational waste unit covers, some drainage may occur through the covers into the waste zone. 


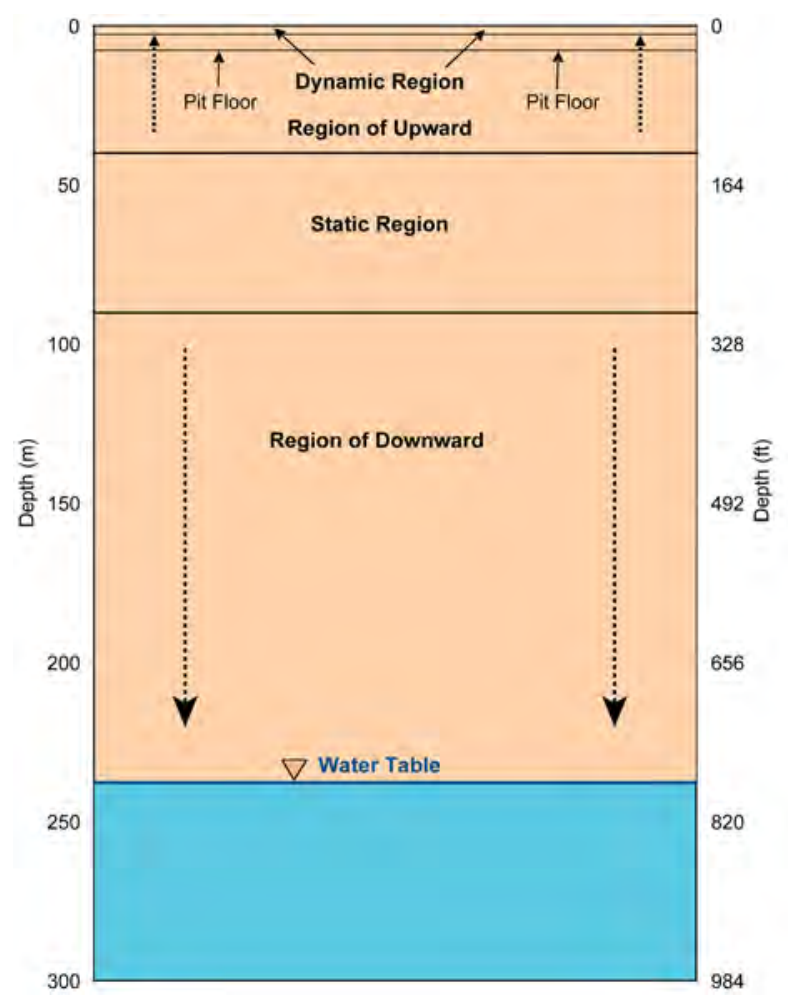

Dynamic Region: magnitude and the direction of liquid fluxes are determined by episodic infiltration, evapotranspiration, and processes of biotic transport.

Region of Slow Upward Flow: region where the combination of low precipitation and high potential evapotranspiration leads to a dry zone inducing upward flow of pore water in the unsaturated zone from as deep as about $35 \mathrm{~m}$ $(115 \mathrm{ft})$. Average upward velocity: $0.03 \mathrm{~mm} / \mathrm{yr}$

Waste zone located in region of upward flow

\begin{abstract}
Static Region: region of no vertical liquid (matrix suction and gravitational forces balance). The thickness and the depth below the surface of this region changes with the physical/textural properties of alluvium and in situ water content.
\end{abstract}
Region of Slow Downward Flow: region of steady downward flow driven by gravity (increased water contents allow downward drainage). Extends from the static region to the water table.
Groundwater travel time: $>\mathbf{5 0 , 0 0 0}$ yrs (current conditions)

Figure 5-14. Conceptual Model of Water Flow in the Unsaturated Zone in the Vicinity of the Area 5 Radioactive Waste Management Site

Source: Personal communication B.M. Crowe (2004) cited in BN 2005d.

In March 2005, after a wet winter, soil-water began to accumulate at the base of the bare-soil lysimeter, at a depth of 2 m (6.6 ft) (Personal Communication, L. Desotell, September 21, 2005).

Drainage through the waste covers should not result in any groundwater recharge because the covers will ultimately become partially vegetated, increasing the evapotranspiration.

Furthermore, the water storage potential of the thick vadose zone is very high, and the hydraulic conductivity is low. Deep drainage and potential groundwater recharge appear to be occurring primarily along mountain fronts at the NTS.

\subsection{GROUNDWATER}

\subsubsection{Regional System}

The NTS is located within the Death Valley Regional Flow System (DVRFS), one of the major hydrologic subdivisions of the southern Great Basin. The DVRFS covers an Area of about $40,920 \mathrm{~km}^{2}\left(15,800 \mathrm{mi}^{2}\right)$. This regional flow system consists primarily of volcanic rock in the west and carbonate rock in the east, and is estimated to transmit more than 8.6 million $\mathrm{m}^{3}$ (70,000 ac ft) of groundwater annually. Most of this flow moves through a thick sequence of Paleozoic carbonate rock extending throughout the subsurface of central and southeastern Nevada and is sometimes referred to as the "central carbonate corridor." The division of the 
DVRFS into different groundwater flow systems within the NTS is based on the concept of a groundwater subbasin, defined as the area that contributes water to a major surface discharge.

The three principal groundwater subbasins identified within the NTS region are Ash Meadows, Oasis Valley, and Alkali Flat-Furnace Creek Ranch subbasins. Yucca Flat and Frenchman Flat lie within the Ash Meadows subbasin (Laczniak et al., 1996). Figure 5-15 shows the NTS with respect to these subbasins and general groundwater flow directions. Each of the subbasins consists of several connected hydrographic basins (compare to Figure 1-2).

The Ash Meadows subbasin covers an area of about $10,360 \mathrm{~km}^{2}\left(4,000 \mathrm{mi}^{2}\right)$. Precipitation is believed to recharge the subbasin along its northern boundary at the Belted, Reveille, Timpahute, and Pahranagat Ranges, along its eastern boundary at the Sheep Range, and along its southern boundary at the Spring Mountains. Recharge is also suspected to occur within the subbasin at higher elevations of the Spotted, Pintwater, and Desert Ranges. Groundwater primarily flows through the lower carbonate-rock aquifer and discharges along a line of springs in Ash Meadows. Groundwater flow rates through the different lithologic units of the Ash Meadows subbasin are highly variable. Estimates range from less than 0.3 to more than 300 meters per day (1 to 1000 feet per day), depending on the unit. In general, the regional carbonate-rock aquifer is believed to transmit water at the fastest rate, whereas the basement and Eleana confining units transmit water at the slowest rate, and volcanic and valley-fill aquifers and confining units transmit water at intermediate rates (Laczniak et al., 1996).

The lower carbonate-rock aquifer (LCA) within the Ash Meadows subbasin is the only subsurface pathway by which groundwater leaves Yucca Flat and Frenchman Flat basins. Groundwater flows south from Yucca Flat into Frenchman Flat and then southwest toward downgradient areas (primarily Ash Meadows). Water levels within the lower carbonate-rock aquifer indicate that the gradient is nearly flat (less than $0.3 \mathrm{~m} / \mathrm{km}[1.6 \mathrm{ft} / \mathrm{mi}]$ ) between Yucca Flat and Frenchman Flat and down to the discharge Area at Ash Meadows. This flat gradient is an indication of a high degree of hydraulic continuity within the aquifer, which is probably a result of a high fracture (secondary) permeability (Laczniak et al., 1996).

Winograd and Thordarson (1975) described suites of rock facies and lithologies which exhibit similar hydrologic character. The PA (Shott et al., 1998) summarizes regional hydrogeologic characteristics from this early work.

Recent work for the UGTA project has enhanced the understanding of the hydrology of the NTS through further definition of hydrogeologic and hydrostratigraphic units for use in modeling the geology and hydrology of the NTS Area (Gonzales et al., 1998; Gonzales and Drellack, 1999; and BN, 2005f).

Based on the existing data, and as interpreted from a regional groundwater flow model (DOE, 1997), the overall groundwater flow direction in Yucca Flat and Frenchman Flat is to the south. Groundwater ultimately discharges at Ash Meadows and Franklin Lake Playa to the south and Death Valley to the southwest.

At the NTS, localized perched water occurs principally within the tuff and lava aquitards, in the foothills and ridges flanking the basins. Perched water is not known to occur beneath Yucca Flat or Frenchman Flat (Shott et al., 1998). 
Characterization Report 92-Acre Area Section: Site Characteristics

Revision: 0

Date: June 2006

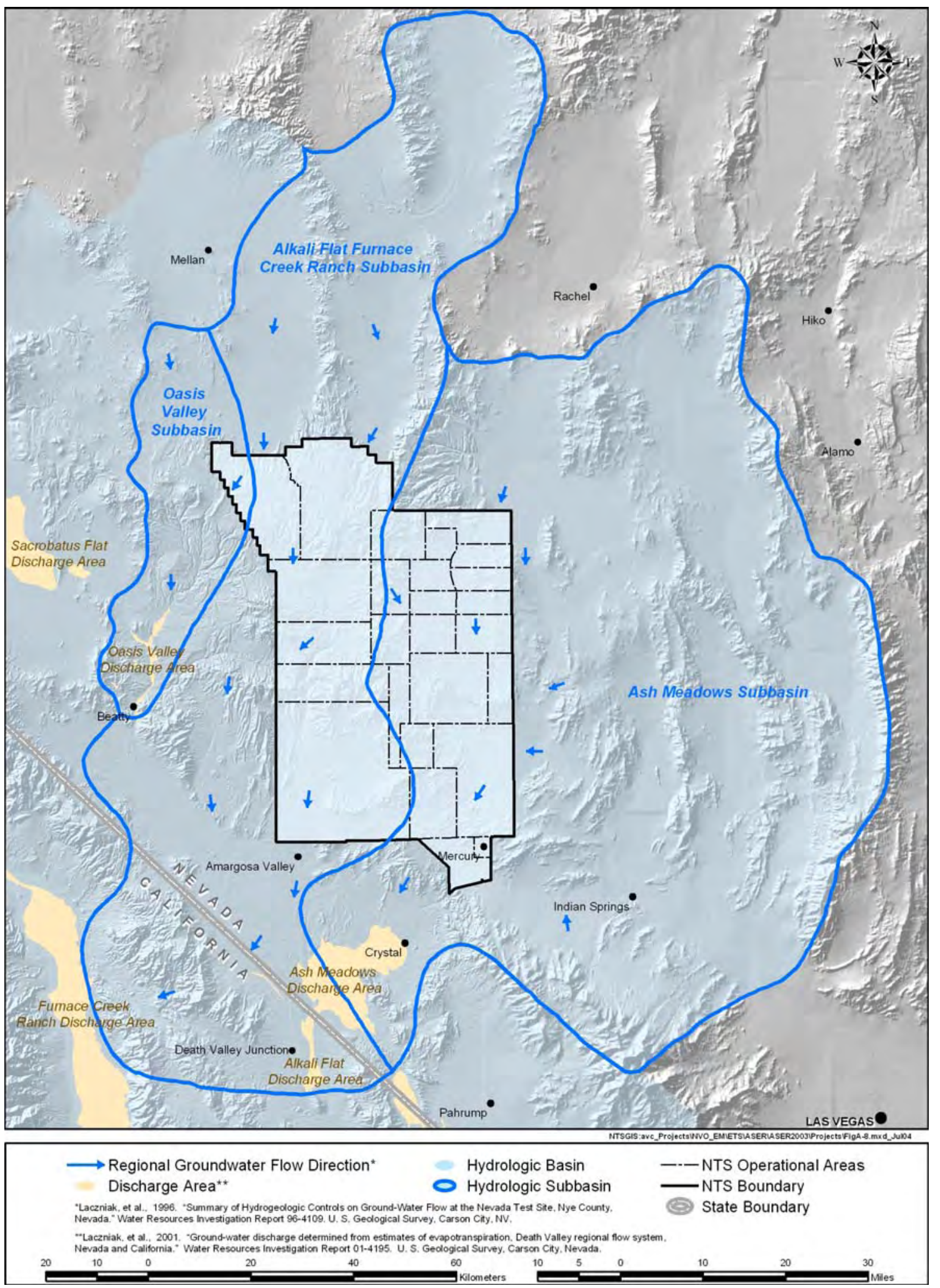

Figure 5-15. Groundwater Basins and Regional Groundwater Flow Directions 
In the area of Frenchman Flat there is essentially a two aquifer system. Unsaturated alluvium overlies the interconnected Alluvial Aquifer and Timber Mountain Aquifer, which is separated from the deeper LCA by low permeability confining units. Figure 5-16 presents a schematic regional cross-section, of the west east profile through the location of Well ER-5-3\#2, which is about 2,500 $\mathrm{m}(8,200 \mathrm{ft})$ northeast of the Area 5 RWMS. The profile was generated from a hydrostratigraphic model of the region (BN, 2005f).

The depth to the static water level in Frenchman Flat ranges from $210 \mathrm{~m}$ (690 ft) near the central playa to more than $350 \mathrm{~m}(1,150 \mathrm{ft})$ at the northern end of the valley. In the deeper, central portions of the basin, more than half of the alluvium section is saturated. Water-level elevation data in the alluvial aquifer indicate a very flat water table (IT, 1998).

Water-level data for the LCA in the southern part of the NTS are limited, but indicate a fairly low gradient in the Yucca Flat, Frenchman Flat, and Jackass Flats area. This gentle gradient implies a high degree of hydraulic continuity within the aquifer, presumably due to high fracture permeability (Laczniak et al., 1996). Furthermore, the similarity of the water levels measured in Paleozoic rocks (LCA) in Yucca Flat, Frenchman Flat, and Mercury Valley implies that, at least for deep interbasin flow, there is no groundwater barrier among the three basins. Inferred regional groundwater flow through Frenchman Flat is to the south, turning southwest in Mercury Valley toward discharge areas in Ash Meadows. An increasing westward flow vector in southern NTS may be due to preferential flow paths subparallel to the northeast-trending Rock Valley fault (Grauch and Hudson, 1995) and/or a northward gradient from the Spring Mountain recharge area (IT, April 1999a, b).

In 1998, a three-dimensional framework model of the hydrostratigraphy of the Frenchman Flat CAU was developed for the DOE/NV UGTA Subproject of the Environmental Restoration Program. The framework model will be used in computer models to predict groundwater flow and contaminant migration within Frenchman Flat. This hydrostratigraphic model (IT, 1998), is still being refined as new data are gathered. The latest information is in the BN (2005f) report, A Hydrostratigrapohic Model and Alternatives for the Groundwater Flow and Contaminant Transport Model of Corrective Action Unit 98: Frenchman Flat, Clark, Lincoln, and Nye Counties, Nevada.

Recent hydrogeological investigations and geophysical studies under the UGTA program have contributed to the understanding of the subsurface structure and hydrogeology at Frenchman Flat. Two hydrogeologic investigation well clusters were recently drilled. The first group of wells was drilled in northern Frenchman Flat. The deepest of those wells, Well ER-5-3\#2, was drilled to a total depth of 1,732 m (5,683 ft), and it penetrated the regional carbonate aquifer (known as the lower carbonate aquifer). A second cluster of wells was drilled in central Frenchman Flat. The deepest well in this group, Well ER-5-4\#2, was drilled to a total depth of 2,134 m (7,000 ft) and does not penetrate the lower carbonate aquifer. These wells are located roughly $2,500 \mathrm{~m}(8,200 \mathrm{ft})$ to the northeast and 3,400 m (11,155 ft) to the southwest of the Area 5 RWMS.

A three-dimensional seismic survey was conducted in Frenchman Flat in 2002 to help delineate the subsurface geologic units and to adjust the UGTA three-dimensional framework model (L. Prothro, written communication to P. K. Ortego [BN], August 8, 2002). The U.S. Geological Survey estimated the depth of the Frenchman Flat basin using a gravity inversion method (Phelps and Graham, 2002). 
Characterization Report 92-Acre Area Section: Site Characteristics

Revision: 0

Date: June 2006
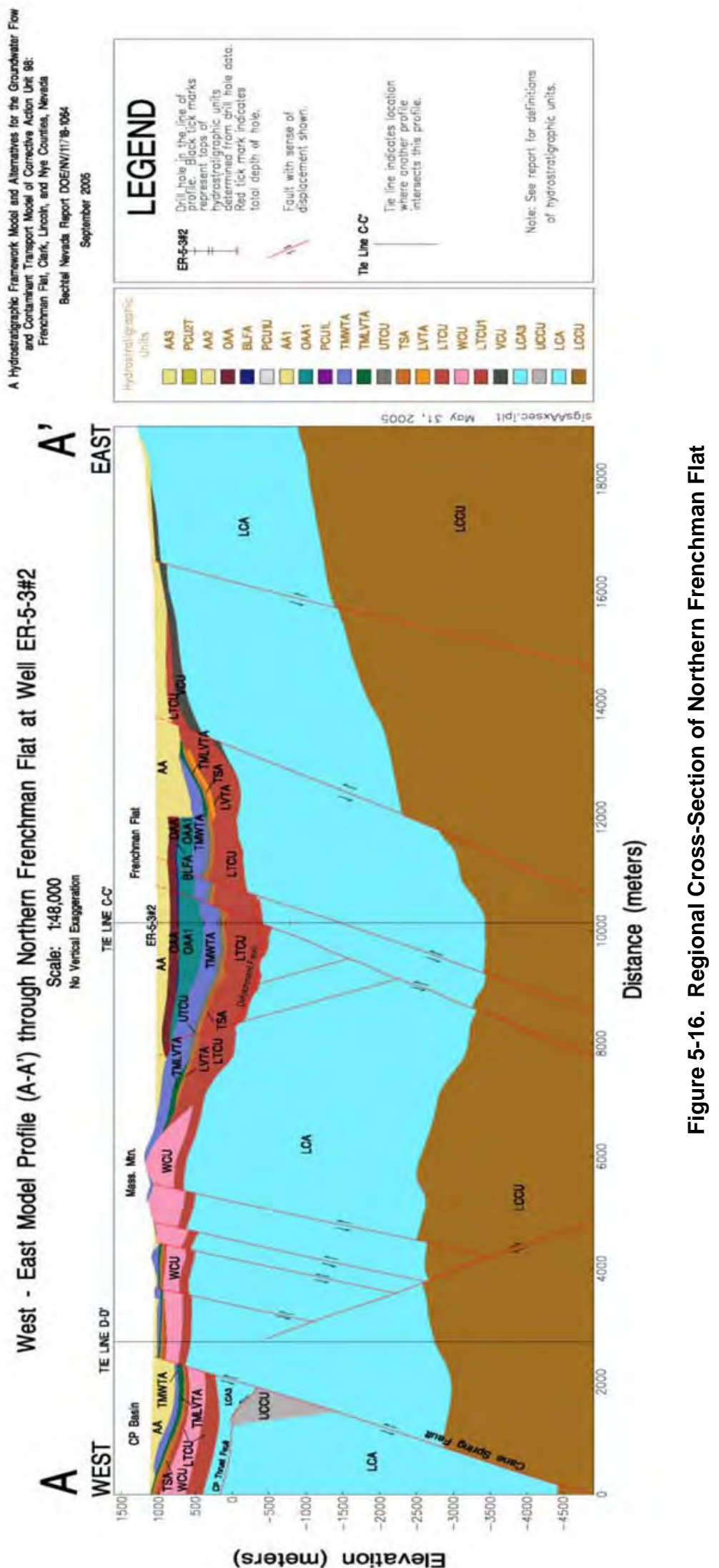
Date: June 2006

\subsubsection{Area 5 RWMS Groundwater Levels and Flow}

From March 1993 through 1997, groundwater levels were measured frequently and on an irregular schedule at the three pilot wells surrounding the Area 5 RWMS. Since 1998, groundwater levels have been measured quarterly. Groundwater data are presented in annual data reports, the latest published was for 2004 (BN, 2005h). Table 5-3 summarizes elevation, gradient, and flow-direction results.

Table 5-3. March 22, 1993, through January 2 2005, Groundwater Elevation Flow

\begin{tabular}{|c|c|c|c|c|c|c|}
\hline & $\begin{array}{l}\text { UE5PW-1 } \\
\text { Elevation } \\
\text { (m amsl) }\end{array}$ & $\begin{array}{l}\text { UE5PW-2 } \\
\text { Elevation } \\
\text { (m amsl) }\end{array}$ & $\begin{array}{l}\text { UE5PW-3 } \\
\text { Elevation } \\
\text { (m amsl) }\end{array}$ & $\begin{array}{l}\text { Approximate } \\
\text { Flow } \\
\text { Direction } \\
\text { Degrees } \\
\text { East of } \\
\text { North }\end{array}$ & $\begin{array}{c}\text { Gradient } \\
(\mathrm{m} / \mathrm{m})\end{array}$ & $\begin{array}{c}\text { Velocity } \\
\text { (m/yr) }\end{array}$ \\
\hline Number of readings & 93 & 93 & 93 & 94 & 94 & 94 \\
\hline Minimum & 733.59 & 733.64 & 733.46 & 5 & $9.95 \mathrm{E}-06$ & 0.01 \\
\hline Maximum & 734.01 & 733.99 & 733.88 & 176 & $1.48 \mathrm{E}-04$ & 0.14 \\
\hline Mean & 733.77 & 733.74 & 733.64 & 103 & 7.61E-05 & 0.07 \\
\hline $\begin{array}{l}\text { Coefficient of } \\
\text { Variation }\end{array}$ & $0.01 \%$ & $0.01 \%$ & $0.02 \%$ & $48 \%$ & $52 \%$ & $52 \%$ \\
\hline
\end{tabular}

Notes:

mamsl = meters above mean sea level

Elevations are corrected for borehole deviation and distance of top of casing to ground surface.

Source: Statistics derived from data within the 2004 Data Report: Groundwater Monitoring Program Area 5 Radioactive Waste Management Site (BN, 2005h) and an unpublished spreadsheet including the January 2005 results (personnel communication, David Hudson, 2005).

The gradient of the potentiometric surface of the groundwater in the alluvial/tuff aquifer has consistently been very low, almost flat, across the Area 5 RWMS site. The average gradient is only $7.61 \mathrm{E}-05 \mathrm{~m} / \mathrm{m}$. Calculated groundwater flow velocities have generally been less than 0.15 meters per year $(\mathrm{m} / \mathrm{yr})(0.5 \mathrm{ft}$ per year [ft/yr]). The average velocity observed between March 1993 and January 2005 was approximately $0.07 \mathrm{~m} / \mathrm{yr}(0.23 \mathrm{ft} / \mathrm{yr})$. The average flow velocity in 2004, the latest published year of record, ranged from 0.02 to $0.12 \mathrm{~m} / \mathrm{yr}$ ( 0.066 to $0.39 \mathrm{ft} / \mathrm{yr}$ ) with an average of $0.08 \mathrm{~m} / \mathrm{yr}(0.33 \mathrm{ft} / \mathrm{yr})$. The calculated flow direction is highly variable but generally has had an eastern component; it has ranged from about 5 degrees to 170 degrees east of north since 1993.

Because the water table is so flat, even small typical groundwater measurement errors of plus or minus $0.25 \mathrm{~cm}$ (0.01 in) can significantly affect the calculated flow direction and velocity. Consequently, although the measured elevations at each well are very consistent through time, the gradient and flow velocities have a much higher coefficient of variance.

Figure 5-17 graphically presents groundwater elevations from 1993 through 2004. Groundwater elevations and depth-to-water from ground surface have varied very little. The depth-to-water measurements collected between March 22, 1993, and October 21, 2002, ranged from $0.35 \mathrm{~m}$ 


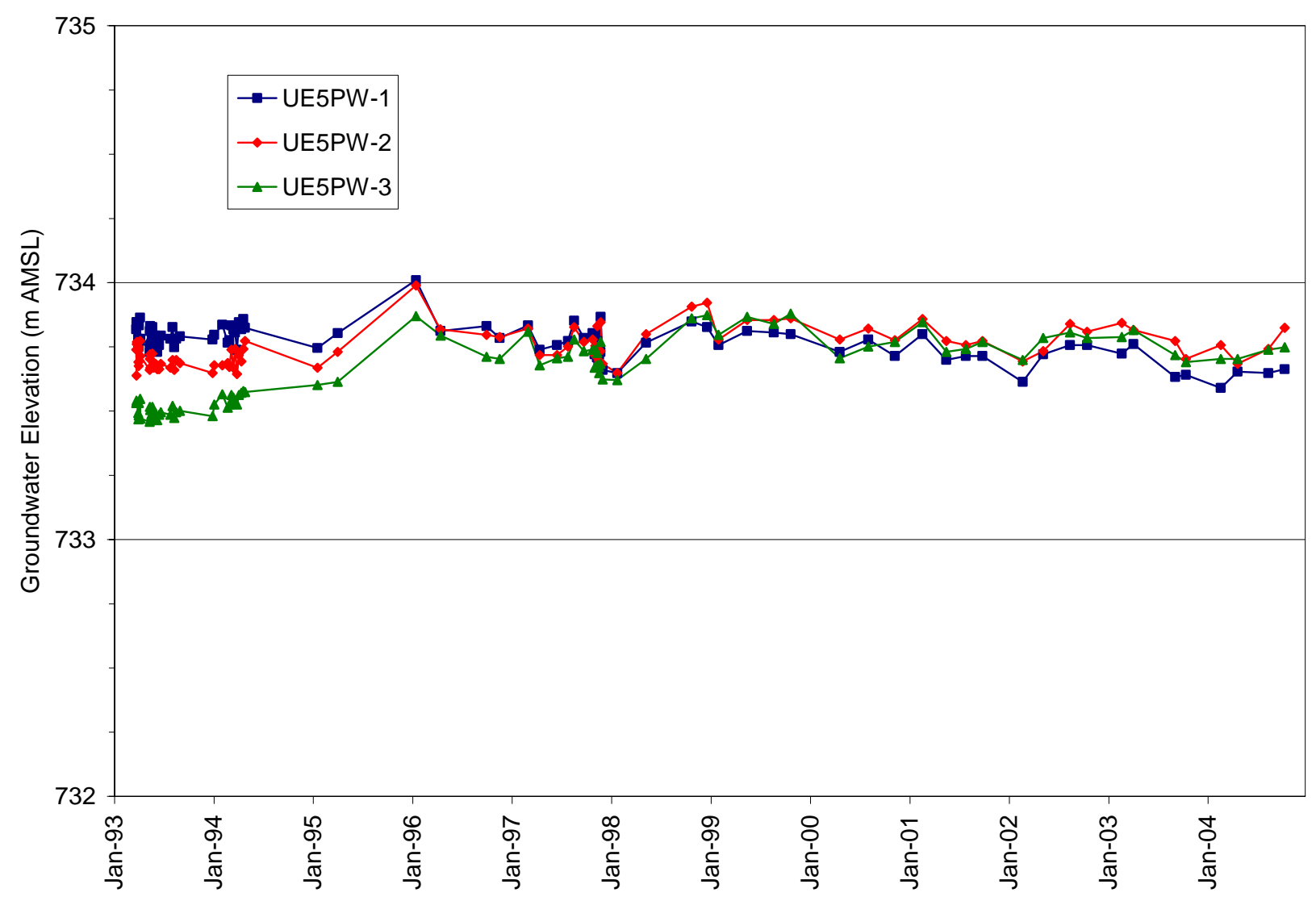

Figure 5-17 Groundwater Elevation at the Area 5 RWMS 1993 through 2004

Source: BN (2005c)

$(1.15 \mathrm{ft})$ at $\mathrm{Ue} 5 \mathrm{PW}-2$, to $0.4 \mathrm{~m}(1.3 \mathrm{ft})$ at Ue5PW-1, and $0.42 \mathrm{~m}(1.38 \mathrm{ft})$ at Ue5PW-3 over this 10 -year period. Average depth-to-water from ground surface at UE5PW-1, UE5PW-2, and

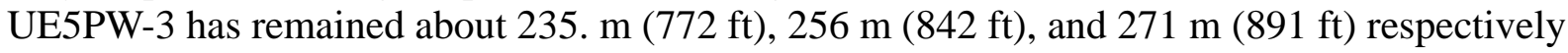
(BN, 2003b and 2005c).

\subsubsection{Groundwater Chemistry}

Three types of groundwater chemistry facies dominate the region: (I) a calcium-magnesium bicarbonate (Ca-Mg- $\mathrm{HCO}_{3}$ ) facies within the carbonate units, (II) a sodium and potassium bicarbonate (Na-K- $\mathrm{HCO}_{3}$ ) facies derived from groundwater in volcanic rocks, and (III) a mixed facies containing components from both (I) and (II). The Na-K-HCO 3 facies (II) is found within the lava-flow aquifer and tuff-aquitards units. The facies also is seen in portions of the valley-fill aquifer, where a major portion of the alluvial-fill material has been derived from the erosion of volcanic units. The Ca-Mg- $\mathrm{HCO}_{3}$ composition (I) is found within the Paleozoic carbonate units, such as the LCA and in the valley-fill aquifers that are composed of carbonate detritus. Most of the calcium and magnesium present is from the dissolution of limestone and dolomite $\left(\mathrm{CaCO}_{3}\right.$ and $\mathrm{CaMg}\left[\mathrm{CO}_{3}\right]_{2}$ ) mineralization in the unit as it conducts flow. Water of the mixed facies (III) contains portions of both the Na-K and Ca-Mg ions groups (Chapman, 1994; Winograd and Thordarson, 1975). 
The 2002 Data Report: Groundwater Monitoring Program, Area 5 Radioactive Waste Management Site (BN, February 2003) indicates the groundwater pumped from the three wells immediately surrounding the Area 5 RWMS is sodium bicarbonate water. Wells Ue5PW-1 and Ue5PW-2 are completed in the alluvial aquifer and Ue5PW-3 to the northeast is completed in the Timber Mountain Tuff Aquifer. These two aquifers have similar hydrochemistry and groundwater elevation, and may be connected.

\subsubsection{Groundwater Quality}

This section is extracted from the Characterization Report for the Operational Soil Covers (BN, 2005d).

Groundwater quality in the vicinity of the Area 5 RWMS is monitored in accordance with the requirements of RCRA and DOE Orders. In 1993, DOE began monitoring the three pilot wells surrounding the Area 5 RWMS (Ue5PW-1, -2 and -3) in compliance with Title 40 CFR 265, Interim Status Standards for Owners and Operators of Hazardous Waste Treatment, Storage and Disposal Facilities. The wells were originally drilled in 1992 as characterization wells for determination of physical and chemical properties of drill core, for determination of chemical properties of groundwater in the uppermost aquifer, and for determination of depths to the uppermost aquifer. NDEP agreed that these wells appear to meet the applicable design, construction, and development criteria for RCRA groundwater monitoring wells. Details of pilot well construction can be found in BN (2005e). Copies of the well logs and details are in Appendix E.

The monitoring program originally included all parameters required by Title 40 CFR 265 including drinking water parameters in Appendix III. A revised groundwater monitoring program outline was approved by NDEP in 1998. The approved modified monitoring program is modeled after the Title CFR 264.98 Detection Monitoring Program, and monitors parameters particular to the use and character of the site.

Currently, groundwater samples from the three pilot wells are analyzed semiannually for the following parameters (BN, 2004b):

Indicators of Contamination:

- $p H$

- Specific conductance

- Total organic carbon (TOC)

- Total organic halogen (TOX)

- Tritium

General Water Chemistry Parameters:

- Total Ca, Fe, Mg, Mn, K, Na, Si

- Total SO4, Cl, F

- Alkalinity 
Conservative investigation levels for the indicators of contamination were negotiated between NDEP and DOE in 1998. Under the semi-annual monitoring program for RCRA compliance, if a parameter investigation level is exceeded, the groundwater is resampled and analyzed for that parameter to confirm the result. Table 5-4 lists the investigation levels. The investigation levels for $\mathrm{pH}$ and specific conductance are based on statistical analysis of data collected from 1993-1996. The levels for TOX and TOC are set slightly above the method detection limits and the tritium level is set at 10 percent of the drinking water standard. See the data reports for further detail (e.g., BN, 2004b).

Table 5-4. Investigation Levels for Indicator Parameters

\begin{tabular}{|l|l|}
\hline \multicolumn{1}{|c|}{ Parameter } & \multicolumn{1}{c|}{ Investigation Level } \\
\hline \hline $\mathrm{pH}$ & Less than 7.6 and greater than 9.2 \\
\hline Specific Conductance & 0.440 millimhos per centimeter \\
\hline TOC & 1 milligrams per liter $(\mathrm{mg} / \mathrm{L})$ \\
\hline TOX & 50 micrograms per liter $(\mu \mathrm{g} / \mathrm{L})$ \\
\hline Tritium & 2,000 picocuries per liter $(\mathrm{pCi} / \mathrm{L})$ \\
\hline
\end{tabular}

(BN, 2003)

Additional groundwater monitoring requirements driven by DOE Orders, and independent of EPA requirements, were determined through a DQO-driven process and are detailed in the Nevada Test Site Routine Radiological Environmental Monitoring Plan (DOE/NV/11718--804, BN, 2003a). Based on Tables B-2 and B-3 in Appendix B of the plan, the three wells surrounding the RWMS are also tested:

Annually for:

- Enriched tritium analysis

Biennially for:

- Gross alpha

- Gross beta

- Gamma spectroscopy

- Plutonium

- $p H$

- Specific Conductivity

- Temperature

- Principal cations and anions

- Total dissolved solids

- Alkalinity

And every 3 years for:

- Strontium-90 $\left({ }^{90} \mathrm{Sr}\right)$

- Technetium-99 $\left({ }^{99} \mathrm{Tc}\right)$

- Carbon-14 $\left({ }^{14} \mathrm{C}\right)$ 
Groundwater monitoring data are presented in detail in the annual groundwater monitoring data report (e.g., BN, 2004b). Appendix F contains a summary of groundwater quality data from the latest annual report (BN, 2005h). All groundwater sampling data from the Area 5 RWMS pilot wells to date indicate that the groundwater in the uppermost aquifer is unaffected by RWMS or NNSA weapons testing activities.

Highlights of the results to date:

- Tritium concentrations in the groundwater beneath the Area 5 RWMS have never exceeded the method detection limit for enriched tritium analysis (approximately $15 \mathrm{pCi} / \mathrm{L})$.

- TOX and TOC analytical results were rechecked a few times in 1998-2000 due to exceedances of investigation limits; however, the follow up samples results were all below the action levels.

- Specific conductance and $p H$ have been very consistent through time and are well within the investigation limits.

- General water chemistry parameter analytical results have also been very consistent since monitoring began. No site-specific investigation levels appear to have been established for these parameters. Concentrations have been low, and generally well below aesthetic secondary standards for drinking water, with two isolated exceptions: $0.11 \mathrm{mg} / \mathrm{L}$ of manganese was found in a sample from UE5PW-2 in March 1993, which is above the $0.05 \mathrm{mg} / \mathrm{L}$ manganese secondary standard; and $0.33 \mathrm{mg} / \mathrm{L}$ of iron was detected in a sample from UE5PW-2 in October 2002, which is above the $0.3 \mathrm{mg} / \mathrm{L}$ iron secondary standard. The National Secondary Drinking Water Regulations are non-enforceable guidelines for water quality parameters that can affect drinking water taste, odor, or color or may cause cosmetic staining.

The potential for groundwater quality impacts from the Area 5 RWMS waste storage is low because vertical movement of percolating water is limited by many factors including climate and geology. Except for short term events, evapotranspiration is much higher than precipitation. There is insignificant stormwater runoff, there has been no apparent recharge in the immediate vicinity, and there are no known potential conduits deeper than the GCD boreholes that could speed transmission of potential leachate deeper. See Section 5.5.2 (Unsaturated Zone).

Groundwater elevation data indicate that the water table beneath the Area 5 RWMS is nearly flat, with groundwater flowing in a northeastern direction at a horizontal velocity of approximately $23 \mathrm{~cm}$ (9 in) per year (BN, 2004b). If contaminants from any source were find a way to reach groundwater, lateral movement of the plume would be relatively slow in this area. UE5PW-2 is downgradient of the Area 5 RWMS, UE5PW-1 is crossgradient to downgradient and UE5PW-3 is upgradient of the Area 5 RWMS. See Section 5.7.2., "Area 5 RWMS Groundwater Levels and Flow." 


\subsection{AIR QUALITY}

Air monitoring is conducted to confirm that RWMS activities do not result in significant radionuclide concentrations above background and to confirm compliance with the National Emissions Stgandard for Hazardous Air Pollutants (NESHAP). Air quality results are summarized in the annual Waste Management Monitoring Report. The latest report is for 2004 (BN, 2005c).

\subsubsection{Tritium}

The NTS began an air sampling program for tritium in January 1980. Tritium is a highly mobile conservative tracer. Tritium concentration in the air near the RWMS, compared to background concentrations at the NTS, is an indicator of how well the waste disposal cells are mitigating migration of volatile radionuclides from waste cells. Data from Guard Station 510, at the southwest edge of the NTS, is considered representative background. Tritium concentrations from the RWMS are also compared to tritium concentrations from the Area 20 Schooner monitoring station at the northwest corner of the NTS, in the vicinity of the soils with elevated tritium levels from the Plowshare tests.

Routine sampling at Area 3 RWMS was terminated in 1997 because of lack of detectable tritium and the relatively low volume of tritium sources disposed at the Area 3 RWMS. Due to recent and potential future disposal of tritium sources, bi-weekly sampling for tritium in atmospheric moisture resumed November 8, 2004, at two monitoring stations at the Area 3 RWMS.

Monitoring at the northeast station at the Area 5 RWMS was abandoned in June 2003 due to development of additional disposal pits. The station will not be replaced because remaining stations (U.S. Department of Defense [DoD] and Sugar Bunker North) provide adequate monitoring coverage of the prevailing downwind locations from the buried tritium sources (south and north). The stations are typically monitored twice a month.

Most of the RWMS samples to date have had no detectable tritium at or above the mean minimum detectable concentration (MDC) for the analytical method, which is about 1 picoCurie per cubic meter $\left(\mathrm{pCi} / \mathrm{m}^{3}\right)$. The tritium concentrations in atmospheric moisture samples from near the Area 3 and 5 RWMS have consistently been orders of magnitude below the DOE Derived Concentration Guide (DCG) for tritium, which is $1 \mathrm{E} 05 \mathrm{pCi} / \mathrm{m}^{3}$. The DCG is the concentration of a radionuclide in air that could be inhaled for one year and not exceed the DOE primary radiation standard to the general public of 100 milliroentgens equivalent man per year (mrem/yr) effective dose equivalent.

In 2004, the tritium concentrations in air samples from the Area 5 and Area 3 RWMS, the Schooner site, and the Guard Station 510 were below the DCG limit for a $10 \mathrm{mrem} / \mathrm{yr}$ exposure. Area 5 RWMS tritium levels were similar to the background levels for most of 2004, and significantly lower than the concentrations in samples from the Schooner monitoring station. For several months, tritium levels in air samples from the Area 5 RWMS were slightly higher than background levels at the guard Station 510, but in samples collected in August and November, the Area 5 air concentrations of tritium were below background (2005c). 
The Sugar Bunker North station tritium concentrations have been slightly higher than the DoD station tritium concentrations, with few exceptions. Concentrations in samples from the DoD station were often below the MDC. Measured concentrations have been so low and so near background it is difficult to determine if this trend has any significance with respect to the landfill or potential offsite sources.

Comparison of the Area 5 RWMS air monitoring data to soil gas and biota data suggests tritium migration to ground surface has been negligible to date. For the past 15 years, soil gas tritium concentrations measured at shallow depths at the GCD-05U borehole have been fairly low (Section 5.6.3). Although there has been some evidence of tritium migration upward through the soil from the waste (the top of which is below $19.8 \mathrm{~m}$ [65 ft] to about $15 \mathrm{~m}$ [50 ft] depth), not much if any has migrated to the root zone of plants. Minimal amounts of tritium have been found in biota surveys (Section 5.3.3).

\subsubsection{Particulates}

Air particulates have been monitored since January 1980. Air particulate samples are collected weekly from monitoring stations near the RWMSs and are screened for gross alpha and gross beta activity to provide early detection of any changes. Monthly composites of filters from each sampling location are analyzed for gamma emitters, and americium and plutonium concentrations. Air particulate monitoring data indicate that radionuclide concentrations in air at the RWMSs are not above those of other nearby stations. The concentrations of all the analytes in samples from the RWMSs were similar to concentrations elsewhere at the NTS and well below the DCG for each radionuclide.

Bechtel Nevada (2005c) summarizes the 2004 analytical results graphically, and indicates no detectable man-made gamma activity. Americium-241 was detected in samples at concentrations very near or below the MDCs for the analytical method. At the Area 5 RWMS, Americium-241 was detected slightly above the average MDC in the February Sugar Bunker North sample and in the September Area 5 DoD sample. Plutonium-238 was not detected in any Area 5 or Area 3 RWMS particulate sample above the MDC. Plutonium-239 was detected in two monthly samples from the Sugar Bunker North station and four samples from the Area 5 DoD station. Plutonium-239 concentrations at several NTS locations showed a slight increasing trend between January and September 2004 and a declining trend in October and November 2004, but all measurements were below the DCG limit for a $10 \mathrm{mrem} /$ year dose exposure. Concentrations detected in Area 3 RWMS samples are generally higher than Area 5 RWMS levels but there are contaminated areas around the Area 3 RWMS which could be contributing to air particulate levels in that area.

\subsubsection{Radon}

Radon is both a natural and man-made radionuclide. Radon flux has been monitored several times at locations around the NTS since 2000. Future monitoring is planned on at least an annual basis. The performance objectives under DOE O 435.1 and the regulatory limit under Title 40 CFR 61, Part Q for the Area 5 and Area 3 RWMSs are the same: 20 picocuries per square meter 
per second $\left(\mathrm{pCi} / \mathrm{m}^{2} / \mathrm{s}\right)$. Measurements of radon flux at the operational waste covers compared to undisturbed and control locations away from the waste areas were of similar magnitude, at or below $4 \mathrm{pCi} / \mathrm{m} 2 / \mathrm{s}$. Radon flux measured at operationally closed waste cells has consistently been at least five times lower than the standards.

Bechtel Nevada (2005c) summarizes radon flux data from 2004. Three areas at the Area 5 RWMS were monitored that year:

- $\quad$ POU1, which is a closed landfill cell with a relatively high radium inventory compared to the rest of the Area 5 RWMS;

- The north end of Pit 13 which contains thorium waste and is in the expansion Area outside of the 52 Acre Area; and

- A broad survey of the expansion area.

The highest measured fluxes were in the expansion area, but the levels were still below about 4 $\mathrm{pCi} / \mathrm{m}^{2} / \mathrm{s}$. RWMS waste management activities do not appear to have significantly affected radon levels at the NTS.

\subsection{RADIATION EXPOSURE}

Information for this Section is derived from the 2004 Waste Management Monitoring Report (BN, 2005c).

Ionizing radiation from both natural and man-made sources is measured quarterly through a network of thermoluminescent dosimeters (TLD). Twelve TLD stations are located around and in the Area 5 RWMS. Pairs of Panasonic UD-814AS TLDs are maintained at each location. The results from these locations are compared to other locations at the NTS including the Gate 100 entrance at the south end of the NTS. The readings are used to calculate the potential dose to a hypothetical person living year round at the RWMS, a scenario unlikely to occur during active maintenance of the NTS as a limited access federal facility. The data are also collected to detect changes in gamma radiation levels, which must be evaluated in the context of on-RWMS and near-RWMS activities and operations, to determine if these changes may indicate a breach in the containment.

Evaluation of any contribution of radiation from operations at the RWMSs is complicated by other sources in the area. Historic activities contribute to exposure rates in the vicinity of the RWMSs. Between1965 and 1971, 9 of 10 underground nuclear tests conducted within $3 \mathrm{~km}$ (1.9 miles) of the Area 5 RWMS released radioactivity to the surface.

Data collected from 1998 through 2004 indicate that direct radiation exposure at the Area 5 RWMS is low. Levels at all the sites were below 1.8 milliroentgens per day (mR/day). The performance objective set in DOE O 435.1 states LLW disposal facilities be sited, designed, operated, maintained, and closed so that a reasonable expectation exists that dose to representative members of the public, shall not exceed $25 \mathrm{mrem} / \mathrm{yr}$ total effective dose equivalent (TEDE) from all exposure pathways, excluding the dose from radon. 
The 2004 average exposure rate at the RWMS boundaries and inside the RWMSs was $0.36 \mathrm{mR} /$ day and similar magnitude to the average exposure rate at background NTS locations, which was $0.30 \mathrm{mR} /$ day. The net average dose in or at the Area 3 and Area 5 RWMS boundaries is approximately $0.06 \mathrm{mrem} /$ day or $22 \mathrm{mrem} /$ year.

In the first quarter of 2004, the exposure rate at the northwest corner of the Area 5 RWMS TLD location was slightly higher than background stations, but still far below regulatory limits. This variation is thought to be from waste shipments being placed in Pit P11U.

For further information, see the annual Waste Management Monitoring Reports (e.g., BN, 2005c).

\subsection{NATURAl HazARDS AND SubsidenCE}

Subsidence is expected to occur as waste and cover-fill materials settle through time. Differential settling, especially across disposal feature margins, causes cracks at ground surface which could provide vertical migration pathways for water, vapor, and mobile contaminants. Depressions, which can retain water after rainstorms, allow more water to infiltrate and more plants to grow on the landfill covers. Large-volume groundwater withdrawals could also cause regional subsidence as the alluvial aquifer is dewatered, should groundwater pumping increase substantially in the future. However, such broad-scale subsidence is less likely to impact the future waste covers.

Natural hazards that may affect the LLW disposal areas include seismic activity and flooding. The hazard of volcanic activity has a sufficiently low probability to be discounted over the operational life and foreseeable future of the facility.

While these natural and incidental hazards are unpredictable, studies have been done to determine the relative risk of these hazards impacting the disposal sites and measures have been implemented to reduce the risk of containment failure. The following subsections summarize some of the studies and monitoring activities related to these hazards.

\subsubsection{Seismicity}

This Section is from the ICMP (BN, 2005a).

Seismic hazard studies conducted at the NTS (Campbell, 1980; Battis, 1978; Rogers, et al., 1977; and Hannon and McKague, 1975) agree that the predicted maximum Richter magnitude for an earthquake is between 5.8 and 7.0, with a peak acceleration between 0.7 and $0.9 \mathrm{~g}$ (Note: $\mathrm{g}$ is the acceleration of gravity $9.8(\mathrm{~m} / \mathrm{s} 2)$ or the strength of the gravitational field $(\mathrm{N} / \mathrm{kg})$. The predicted maximum magnitude earthquake (and the associated peak acceleration) has a return period between 12,700 and 15,000 years (Metcalf, 1983). The seismic studies show a 0.54 probability of an earthquake with a Richter magnitude greater than 6.8 within the next 10,000 years. 
Earthquakes with magnitudes between 4.3 and 4.5 occurred in Frenchman Flat in 1971 and 1973 (Case, et al., 1984) and in 1999 (see www.earthquake.usgs.gov;

www.seismo.unr.edu). The 1973 and 1999 earthquakes were associated with the Rock Valley Fault, whereas the 1971 earthquake was associated with the Cane Spring Fault. The focus of this latter earthquake was in the Massachusetts Mountains which separate Yucca Flat and Frenchman Flat. No surface rupture was reported from any of these earthquakes.

Because of the absence of layers that could be disrupted by movement, the monolayer-evapotranspiration design anticipated for closure covers at both RWMSs is intrinsically not prone to significant damage from earthquakes.

\subsubsection{Volcanism}

The following Section is from the ICMP (BN, 2005a).

The risk of volcanism in the NTS region is indicated by the potential for either future silicic or basaltic volcanism. Silicic volcanism is characterized by large-volume, explosive eruptions; whereas basaltic volcanism is characterized by cinder cones and lava flows of limited extent. The hazard for silicic volcanism is considered to be negligible because:

- Since its peak (from 15 to 9 million years ago), there has been a significant decrease and, in most areas, a cessation of silicic volcanism within the central and southern parts of the Great Basin. The last major silicic events were the Black Mountain caldera which erupted 9.4 million years ago and the Stonewall Mountain caldera which erupted 7.6 million years ago.

- Silicic volcanism has been absent in the NTS region for the past 7.6 million years.

- Quaternary (less than 10,000 years) silicic volcanism is restricted to the eastern and western margins of the Great Basin (Crowe, et al., 1983). A transition from predominantly silicic volcanism to basaltic volcanism occurred approximately 10 million years ago.

Late- and post-Miocene basaltic volcanism in the NTS region is divided into two episodes: (1) large-volume basaltic centers that are spatially and temporally associated with the waning phase of silicic volcanism; and (2) small-volume, spatially scattered basalt centers that postdate silicic volcanism (Crowe, 1990). The latter episode of volcanism is subdivided into two cycles: late Miocene basalt centers in the east and north-center of the NTS, and Pliocene and Quaternary basalt centers primarily in the southwest part of the NTS region. The youngest basaltic volcanic center in the NTS region is the 70,000-year-old basalt of Lathrop Wells. The youngest basalt within Yucca Flat, at 8.4 million years, is between 226 and $308 \mathrm{~m}$ (740 and 1,010 ft) deep in borehole UE-1h, $1.6 \mathrm{~km}$ (1 mi) southwest of the Area 3 RWMS. The youngest basalt within Frenchman Flat, at 7.4 million years, is exposed at the surface in Nye Canyon, approximately $21 \mathrm{~km}$ (13 mi) northeast of the Area 5 RWMS. 
The greatest hazard of future basaltic volcanism in the NTS region is within zones of Pliocene and Quaternary volcanism (Crowe, Wallman, et al., 1993). The Area 3 and Area 5 RWMSs are outside and a considerable distance from all Pliocene and Quaternary volcanic zones. Based on studies at Yucca Mountain, Crowe, Wallman, et al. (1998) calculated the probability of magmatic disruption of an equivalent Area outside a volcanic zone to be 3E-09, or 3E-06 over a 1,000-year compliance period. This probability is sufficiently low that basaltic volcanism can be dismissed as a credible event for the RWMSs.

\subsubsection{Flooding}

Three watersheds comprise the drainage area that could impact the Area 5 RWMS: the Barren Wash, Scarp Canyon, and Massachusetts Mountains/Halfpint Range. The total drainage Area of these water sheds is approximately $363 \mathrm{~km}^{2}\left(140 \mathrm{~m}^{2}\right)$. The RWMS is in the middle zone of the Scarp Canyon alluvial fan, near the converging edge of three alluvial fans. Both sheet flow and concentrated flows in ephemeral channels must be considered to evaluate flood hazards for this area. While most of the channels in this Area are shallow and braided, there is a defined drainage which crosses the southwest corner of the RWMS, at the boundary between the Barren Wash Alluvial Fan and the Massachusetts Mountains/Halfpint Range watershed.

Stratigraphic studies of the P03U and P04U wells by Raytheon Services Nevada (1991) indicate the landfill trenches and pits are dug into sheetflood and shallow channel deposits. Observed cut and fill structures were generally less than a meter thick, similar to modern channels, except for one laterally contiguous soil horizon up to 2-m thick. Although the pre-development stratigraphy shows the accretion of sediments through time with periodic erosion. The potential for future flood and erosion impacts at the Area 5 RWMS must take into the account the berms, ditches, roads, and other structures diverting flow from this area.

The RWMSs must comply with the NAC, federal regulations, and DOE policies and orders regarding protection of hazardous and radioactive waste facilities from floods. At least three flood hazard assessments have been performed for the Area 5 RWMS Area to fulfill regulatory requirements and to define criteria for flood protection design.

Schmetzer, et al. (1993) conducted a flood hazard study based on the Federal Emergency Management Agency (FEMA) Alluvial Fan Methodology (AFM). They found that the southwest corner of the Area 5 RWMS was within a 100-year flood hazard zone. This zone is defined by FEMA to have a 0.01 (1 percent) probability that a flood with a depth of flow greater than $0.3 \mathrm{~m}(1 \mathrm{ft})$ could occur within any given year. The southwest corner of the RWMS has the potential for flooding from both alluvial-fan flow on the Barren Wash fan and shallow concentrated flow on the Massachusetts Mountains/Halfpint Range alluvial fan. Other parts of the Area 5 RWMS are within an area referred to as Zone $\mathrm{X}$, where sheetflow resulting from a 100-year, 6-hour precipitation event is anticipated to be less than $0.3 \mathrm{~m}$ (1 ft) deep. Figure 5-18 is a flood hazard map of the vicinity of the Area 5 RWMS.

Miller and Gustafson (1994) conducted a flood assessment using a combination of methods including: the FEMA AFM, HEC-2 modeling for shallow concentrated flow and the Manning equation for sheetflow to identify the 100-year flood hazard at and near the Area 5 RWMS. This 


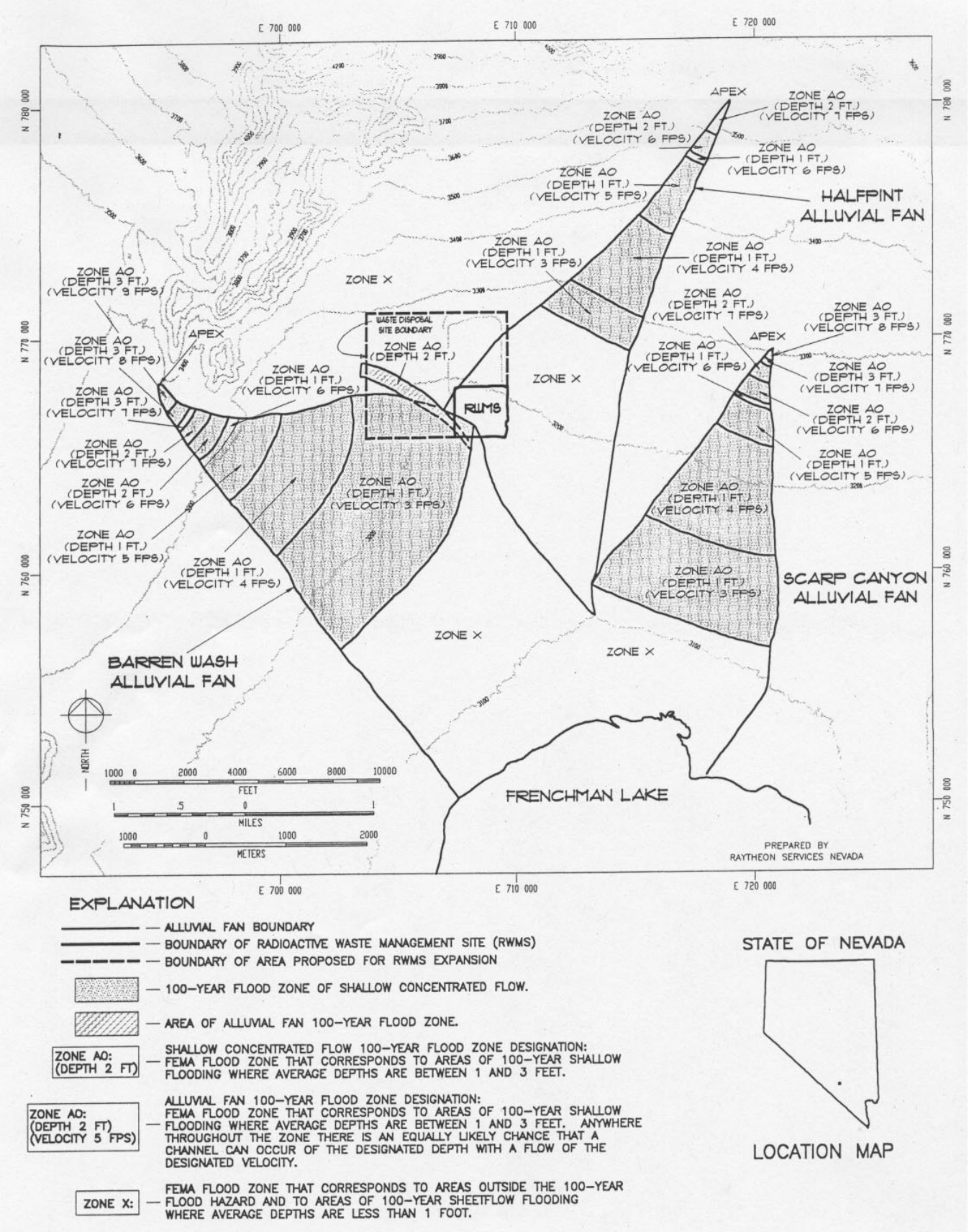

Figure 5-18. 100-Year Flood Zone Delineation Map

Source: A Multiple-Method Approach to Flood Assessment at a Low-Level Radioactive Waste Site in Southern Nevada, by Julianne J. Miller and Dennis L. Gustafson, Raytheon Services Nevada, March 1994.

study also found that the 100-year flood-hazard zone of the Barren Wash Alluval fan impinges on the southwest corner of the Area 5 RWMS. It was noted that the flood-hazard potential from Barren Wash is actually less than the potential determined from the FEMA AFM because the AFM assumption of a uniform probability of a channel being formed may be invalid. Empirical evidence suggests fan-head channels tend to occur near or along the fan centerline. Since the 
RWMS is located along the boundary of a fan and not in the center, the flood hazard potential from Barren Wash may be less than the FEMA model suggests. The study concluded that use of the FEMA AFM for analysis of the Barren Wash Alluvial Fan, with respect to the RWMS, was reasonable but conservative.

The RWMS is within the Zone $\mathrm{X}$ flood zone of the Halfpint alluvial fan, a flood-hazard designation that corresponds to areas outside of the 100-year flood hazard zone, with 100-year

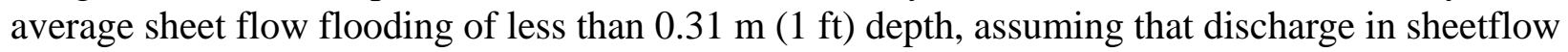
regions is spread equally over the surface. Existing channels within this part of the Halfpint

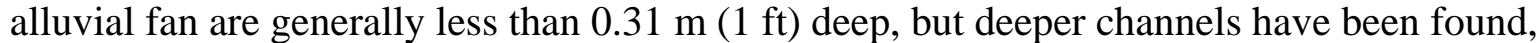

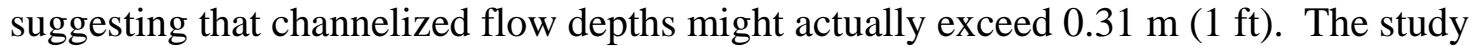
concluded flood protection should address potential for channelized flow at the RWMS in this Zone X hazard area.

HEC 2 model results indicate the drainage between fans which crosses the southwest corner of the Area 5 RWMS has a shallow concentrated flow 100-year flood zone with average depths of

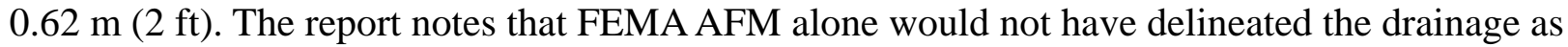
a flood hazard.

Miller, et al (Raytheon Services Nevada, June 1994) conducted a 25-year and 500-year flood hazard assessment of the Area 5 RWMS to determine discharges at points of concentration along the outer edges of berms flanking the Area 5 RWMS. RCRA regulations require the 25-year assessment and DOE O 6430.1a requires the 500-year discharge assessment for "critical action" facilities.

The currently active part of the Area 5 RWMS is now protected from a 25-year, 24-hour flood event via a channel and dike system. These features meet regulatory requirements for flood protection of a RCRA facility.

The original soil berms around the Area 5 RWMS were not designed to any particular flood event. There were reportedly constructed around the north edge as the original pits were excavated. In the mid-1990s new channels and berms were designed and built. The new berms extend from the existing dirt berms north of P03U (Pit 3) along the east and west sides. During the design, both the existing berm and the new ones were analyzed for the 25-year, 24-hour storm event. The construction of the new berms was completed in 1996. Calculation No. FD-DA-C-117 (BN, 1999b) took the calculated flood flows from an actual 25-year, 24-hour storm event (February 23 and 24, 1998) and assessed the adequacy of the existing and as-constructed channel/berm systems (Personal Communication, J. Sorola, August 3, 2005.)

The calculations confirmed that the berm system has adequate freeboard to handle a 25-year 24-hour storm (Personal Communication, Vefa Yucel, August 4, 2005). Recent studies suggest that actual depths of flow and flow velocities may be considerably less than modeled because of water lost into the ground during transmission (French and Curtis, 1999).

Changes in the regulatory status of the site prompted a brief hazard analysis evaluating the potential impacts of a 2000-year storm flood event. DOE has allocated budget to do further 
analysis of flood potential for up to a 2000-year storm event in FY 2006 (Personal Communication, V. Yucel, August 4, 2005).

\subsubsection{Subsidence}

Many factors affect potential subsidence of the landfill covers including but not limited to:

- The types of containers,

- The structural integrity of containers,

- How the containers were packed into the pits and trenches,

- The weight of the stacked containers and the soil covers above,

- The amount of void space within and around the containers, and

- How well the soil covers were compacted.

Potential for subsidence may vary across the 92-Acre Area reflecting the changes in waste types, waste packaging, waste management, and landfill cover operations over the past 45 years. Other factors related to surface erosion and soil structure such as drainage patterns and the distribution of vegetation and animal burrows could eventually influence the potential for local subsidence.

A formal program to monitor the subsidence of waste covers was initiated in October 2000. Subsidence monitoring is conducted to ensure that subsidence features are repaired in a timely manner, to prevent erosion and the development of preferential pathways through the waste covers, and to ensure that vadose zone monitoring data are representative of the entire RWMS. The effectiveness of subsidence monitoring is periodically evaluated as part of the PA process.

At the Area 5 RWMS, subsidence monitoring is conducted monthly at all operationally closed disposal units and at partially buried open disposal units. The monitoring consists of routine inspections of operational and final waste covers for subsidence features such as cracks and depressions, ponding, and erosion. When such features are observed, their locations are recorded using a Global Positioning System and digital camera, and operations personnel are informed to take corrective action.

Locations of observed subsidence features are presented in the annual waste management monitoring reports. Generally, subsidence features have been observed mostly in locations of recently covered waste as well as concentrated along the edges of cells, where compaction may be less complete. In other locations within the Area 5 RWMS, only a few minor cracks and depressions required maintenance (BN, 2005d and 2005c).

In 2004, $62 \mathrm{yd}^{3}$ of fill dirt were used to fill cracks and depressions at the Area 5 RWMS. Subsidence was only found at two disposal units. Seventeen small features were identified and filled at the P05U cover and three features were filled around the northeast corner of the P04U pit (BN, 2005c). These disposal units are on the west side of the 92-Acre Area and are relatively recent pits. P04U was closed sometime after October 31, 1994, and P05U sometime after October 31, 2001 (Denton et al., 2004). 
In the late 1990s, a working group of subject matter experts was convened to evaluate the consequences of subsidence at the Area 3 and Area 5 RWMSs. Relevant major observations and recommendations of that study (DOE, 1998a) were:

- None of the regulations for disposal of LLW at the NTS include specific design requirements for closure caps.

- Performance assessment models should be used to optimize designs for closure of waste disposal sites.

- Closure cover designs should satisfy minimum engineering performance standards and dose-related PA standards.

- An alternative closure cover design consisting of a thick layer of native alluvium should be developed for use at the RWMSs. The cover design should rely upon thickness and evapotranspiration to provide containment.

- The cover should be monitored during the Institutional Control period to monitor performance and allow modification and maintenance if necessary.

- Void spaces between and within the waste packaging should be minimized.

An Alternative Evaluation Study (Barker, 1997) initiated to address potential subsidence concerns recommended:

- Close all NTS waste cells with soft covers, possibly thicker than present operational covers.

- Do not grout or use deep dynamic compaction on any NTS waste cells.

- Encourage generators to minimize spaces void of waste containers.

- Create a database of waste container locations and observed waste subsidence.

- Whenever possible, consider bulk-waste disposal.

Many of these recommendations have already been implemented. Operation practices are now in place to mitigate potential future subsidence over modern disposal units as much as reasonably practicable.

\subsection{Operational Soil Covers}

The operational soil covers at the Area 5 RWMS consists of locally derived native fill collected from the unsaturated alluvium. Generally past closure covers for the shallow pits and trenches at the Area 5 RWMS have been approximately $2.4 \mathrm{~m}(8 \mathrm{ft})$ thick, with $1.2 \mathrm{~m}(4 \mathrm{ft})$ below grade and

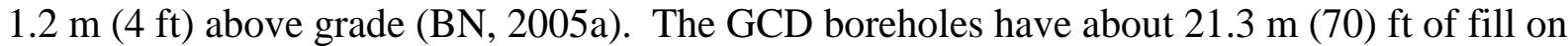
top of the waste. The characteristics and performance of the existing operational closure covers is being considered in the design of the final closure cover for the 92-Acre Area.

In FY 2002, samples were collected from the operational covers over the shallow trenches and pits within the 92-Acre Area of the Area 5 RWMS to document physical characteristics, including basic hydrogeological parameters. The laboratory analytical data reports were presented in a previous characterization report with minimal interpretation (BN, 2005d). This section summarizes data relevant to water, vapor, and potential contaminant transport. Refer to 
the laboratory reports in BN 2005d for the complete data set and further detail on methods, calibrations, and Quality Assurance/Quality Control.

Sampling and test location grids were established for four operational landfill cover areas: P04U, P03U, T01U to T07U, (T01U, T02U, T03U, T04U, T06U, and T07U) and T01C to T06C (T01C, T02C, T03C, T04C, T04C-1, T05C, and T06C).

Sampling access was very limited at T01C-T06C, the cover of the classified material trenches, because security personnel did not want any digging or coring in the classified material area. They did permit collection of a bulk sample from about $1-\mathrm{ft}$ depth from grid point C10. Coring was unsuccessful at this location. The cover material appeared to be unscreened and contained more rocks than at the other sampling locations. It is unknown if this single sample location is representative of the entire cover, based on the data from this study.

All four landfill covers were surveyed for elevation. Nuclear density tests were performed on two of the unclassified covers.

Core samples were collected from a total of 16 locations on the unclassified trench covers at depths of approximately $1 \mathrm{ft}$ and $3 \mathrm{ft}$. Two 6-in core samples and one 3-in core sample were collected from each sample location. Cores were analyzed for bulk density, compaction, soil moisture, porosity, and permeability. One core was also analyzed for hydraulic conductivity.

Bulk samples were collected from six locations, at least one from each of the four landfill covers. Two 5-gal buckets were filled for each bulk sample. The disturbed bulk samples were used for sieve, specific gravity, and Proctor compaction tests.

Tables 5-5 through 5-10 summarize the results. Table 5-5 presents general grain-size distributions derived from sieve analyses results. The six samples had very similar textures, and were comprised primarily of sands. The average fines fraction was about 8 percent by weight, and gravel 21 percent. Most of the gravel was fine (less than about $3 / 4$-in diameter). All the sample material passed a 3-in sieve. The detailed sieve results and gradation curves can be found in Appendix B-6 of the Characterization Report (BN, 2005d).

Table 5-6 summarizes specific gravity data. Average specific gravity of the gravel fraction for the six bulk samples collected from the landfill covers was 2.299. Average specific gravity of the finer-than-US Sieve \#4 fraction was 2.454.

Table 5-7 summarizes Proctor Test (ASTM D 1557-2000) results. The test results for the six samples were very similar. Four to five trials were run for each sample. The average maximum achievable compaction is $109.1 \mathrm{lbs} / \mathrm{ft}^{3}$ at an optimal moisture condition of 11.6 percent. After correction for the presence of gravel, the average maximum achievable compaction is $111.2 \mathrm{lbs} / \mathrm{ft}^{3}$ at an optimum moisture condition of 10.9 percent. Variance of maximum compaction densities was less than 2 percent across the site.

The Proctor Test results are very similar to results from nuclear density tests using a Troxler 3440 gauge. One of the 15 sample locations attempted was not tested due to probe 
refusal on coarse rocks and cobbles. Table 5-8 summarizes nuclear density data. The average of 14 values collected from 14 locations at P03U and P04U on August 19, 2002, yielded a range of dry densities of 99.6 to $109.8 \mathrm{lbs} / \mathrm{ft} 3$ with a mean of $105.6 \mathrm{lbs} / \mathrm{ft}^{3}$ and a coefficient of variance of 2.5 percent. Moisture percent ranged from 1.9 to 3.9 with a mean of 2.5 percent and a coefficient of variance of 21.2 percent. Maximum density in $\mathrm{lbs} / \mathrm{ft}^{3}$ for soils from P03U was 110.1 and for P04U 112.1. Optimum moisture was 10.8 percent at P03U and 10.6 percent at P04U. Percent compaction values ranged from 90.5 to 97.9 with a mean of 94.6 percent and a coefficient of variance of 2.3 percent. The low variance values are indicative of the homogeneity of the operational covers.

Table 5-5. Operational Covers - Grain Size Distribution

\begin{tabular}{|c|c|c|c|c|}
\hline Location & Class $^{1}$ & $\begin{array}{l}\text { Percent Gravel } \\
\text { by Weight }^{2}\end{array}$ & $\begin{array}{l}\text { Percent Sand } \\
\text { by Weight }^{3}\end{array}$ & $\begin{array}{l}\text { Percent Silt and } \\
\text { Clay by Weight }\end{array}$ \\
\hline P03U Logging Tube 22 & SM/SW & 21 & 71.6 & 7.4 \\
\hline P04U Grid Pt B4 & SM/SP & 18 & 71.6 & 10.4 \\
\hline P04U Grid Pt C10 & SM/SW & 25 & 68.6 & 6.4 \\
\hline T01U-T07U Grid Pt F4 & SM/SP & 21 & 70.6 & 8.4 \\
\hline T01U-T07U Grid Pt B4 & SM/SW & 21 & 73.1 & 5.9 \\
\hline T01C-T06C & SM/SP & 20 & 71.0 & 9.0 \\
\hline Average & & 21 & 71.1 & 7.9 \\
\hline Coefficient of Variance $^{5}$ & & $11 \%$ & $2.1 \%$ & $21.3 \%$ \\
\hline
\end{tabular}

Notes:

${ }^{1}$ Assume textural class determined based on ASTM D 2488-90 "Standard Recommended Practice for the Description of Soils - Visual Manual Procedure"

${ }^{2}$ Percent gravel is roughly equivalent to materials retained on a US Standard \# 4 sieve.

${ }^{3}$ Percent sand is equivalent to material passing a \#4 sieve yet retained on a \#200 sieve.

${ }^{4}$ Most silt and clay passes through a US standard \#200 sieve.

${ }^{5}$ Coefficient of Variance $=100$ (standard deviation $/$ mean) percent

Source: Derived from sieve analyses in BN Materials Testing Laboratory September 2002 data report in Appendix B-6 of the Characterization Report DOE/NV/11718-758, Rev 1 (BN, 2005d). 
Characterization Report 92-Acre Area Section: Site Characteristics

Revision: 0

Date: June 2006

Table 5-6. Operational Covers - Specific Gravity

\begin{tabular}{|l|c|c|c|c|}
\hline \multicolumn{1}{|c|}{ Landfill Cover } & Sample Location & $\begin{array}{c}\text { Approximate } \\
\text { Depth }\end{array}$ & $\begin{array}{c}\text { Specific Gravity } \\
\text { Gravel (>sieve \#4) }\end{array}$ & $\begin{array}{c}\text { Specific Gravity } \\
\text { Sand and Fines } \\
\text { (< sieve \#4) }\end{array}$ \\
\hline P03U & Near tube 22 & 3-feet & 2.303 & 2.528 \\
\hline P04U & B4 & 3-feet & 2.311 & 2.496 \\
\hline P04U & C10 & 3-feet & 2.254 & 2.372 \\
\hline T01U-T07U & F4 & 3-feet & 2.210 & 2.382 \\
\hline T01U-T07U & B4 & 3-feet & 2.336 & 2.499 \\
\hline T01C-T06C & C10 & 1-foot & 2.381 & 2.447 \\
\hline Average & & & $\mathbf{2 . 2 9 9}$ & $\mathbf{2 . 4 5 4}$ \\
\hline $\begin{array}{l}\text { Coefficient of } \\
\text { Variance }\end{array}$ & & & $\mathbf{2 . 6 \%}$ & $\mathbf{2 . 7 \%}$ \\
\hline
\end{tabular}

Source: BN Materials Testing Laboratory 8/23/2003 data report in Appendix B-4 of Characterization Report DOE/NV/11718 - 758, Rev 1 (BN, 2005d).

Same samples as used for Proctor Tests.

Table 5-7. Operational Covers - Maximum Achievable Compaction, Proctor Test

\begin{tabular}{|c|c|c|c|c|c|c|}
\hline Location & $\begin{array}{l}\text { Sample } \\
\text { Date }\end{array}$ & $\begin{array}{l}\text { Maximum } \\
\text { Density } \\
(\text { lbs/ft })\end{array}$ & $\begin{array}{c}\text { Optimum } \\
\text { Moisture } \\
\text { percent }\end{array}$ & $\begin{array}{c}100 \% \text { Saturation } \\
\text { Moisture }\end{array}$ & 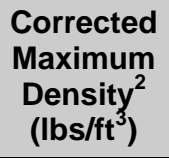 & $\begin{array}{l}\text { Corrected } \\
\text { Optimum } \\
\text { Moisture } \\
\text { Percent }^{2}\end{array}$ \\
\hline $\begin{array}{l}\text { PO3U, near } \\
\text { Logging Tube } \\
22\end{array}$ & $5 / 29 / 02$ & 108.3 & 11.5 & $17.9-18.8$ (4 trials) & 110.1 & 10.8 \\
\hline $\begin{array}{l}\text { P04U } \\
\text { Grid Pt B4 }\end{array}$ & $5 / 29 / 02$ & 110.5 & 11.1 & 16.4-17.5 & 112.1 & 10.6 \\
\hline $\begin{array}{l}\text { P04U } \\
\text { Grid Pt C10 }\end{array}$ & $6 / 19 / 02$ & 107.2 & 13 & $16-16.4$ & 109.8 & 12.0 \\
\hline $\begin{array}{l}\text { T01U-T07U } \\
\text { Grid Pt F4 }\end{array}$ & $6 / 19 / 02$ & 111.1 & 12.2 & $14.2-15.9$ & 113.1 & 11.5 \\
\hline $\begin{array}{l}\text { T01U-T07U } \\
\text { Grid Pt B4 }\end{array}$ & $7 / 3 / 02$ & 107.2 & 9.4 & 17.9-18.6 (5 trials) & 110.0 & 8.7 \\
\hline $\begin{array}{l}\text { T01C-T06C } \\
\text { Grid Pt C10 }\end{array}$ & $7 / 3 / 02$ & 110.2 & 12.5 & 16-17.1 (4 trials) & 112.4 & 11.6 \\
\hline Average & & 109.1 & 11.6 & & 111.25 & 10.9 \\
\hline $\begin{array}{l}\text { Coefficient of } \\
\text { Variance }^{3}\end{array}$ & & $1.6 \%$ & $11.0 \%$ & & $1.3 \%$ & $10.9 \%$ \\
\hline
\end{tabular}

Notes:

${ }^{1} \mathrm{lbs} / \mathrm{ft}^{3}=$ pounds per cubic foot

${ }^{2}$ Correction of unit weight and water content for soils containing oversize particles using ASTM D 4718-87.

${ }^{3}$ Coefficient of variance $=100$ (standard deviation/mean)percent

Same samples as used for specific gravity tests.

Source: BN Materials Testing Laboratory 9/12/2002 data report, Characterization Report DOE/NV/11718 - 758, Rev 1 (BN, 2005d) 
Table 5-8. Operational Covers - Nuclear Density

\begin{tabular}{|c|c|c|c|c|c|c|c|}
\hline Location & Station & $\begin{array}{l}\text { Test } \\
\text { Date }\end{array}$ & $\begin{array}{c}\text { Dry } \\
\text { Density } \\
\text { (lbs/ft }{ }^{3}\end{array}$ & $\begin{array}{c}\text { Moisture } \\
\text { Percent }\end{array}$ & 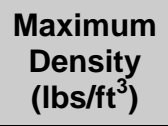 & $\begin{array}{c}\text { Optimum } \\
\text { Moisture } \\
\text { Percent }\end{array}$ & $\begin{array}{c}\text { Percent } \\
\text { Compaction }\end{array}$ \\
\hline PO3U & $A-1^{1,2}$ & $8 / 19 / 02$ & $\mathrm{NT}^{1}$ & NT & NT & NT & NT \\
\hline PO3U & $A-2^{2}$ & $8 / 19 / 02$ & 106.6 & 2.4 & 110.1 & 10.8 & 96.8 \\
\hline PO3U & $A-3$ & $8 / 19 / 02$ & 104.9 & 2.1 & 110.1 & 10.8 & 95.3 \\
\hline PO3U & $\begin{array}{l}\text { Near- } \\
\text { sampling } \\
\text { Tube } 22\end{array}$ & $8 / 19 / 02$ & 99.6 & 1.9 & 110.1 & 10.8 & 90.5 \\
\hline P04U & $A-1^{2}$ & $8 / 19 / 02$ & 105.6 & 1.9 & 112.1 & 10.6 & 94.2 \\
\hline P04U & $C-1^{2}$ & $8 / 19 / 02$ & 103.4 & 2.6 & 112.1 & 10.6 & 92.2 \\
\hline P04U & B-2 & 8/19/02 & 105.1 & 2.5 & 112.1 & 10.6 & 93.8 \\
\hline P04U & $A-3^{2}$ & $8 / 19 / 02$ & 104.8 & 3.9 & 112.1 & 10.6 & 93.5 \\
\hline P04U & $C-3^{2}$ & $8 / 19 / 02$ & 103.8 & 3.1 & 112.1 & 10.6 & 92.6 \\
\hline P04U & B-4 & $8 / 19 / 02$ & 107.4 & 2.9 & 112.1 & 10.6 & 95.8 \\
\hline P04U & $A-5^{2}$ & 8/19/02 & 109.8 & 2.2 & 112.1 & 10.6 & 97.9 \\
\hline P04U & $C-5^{2}$ & $8 / 19 / 02$ & 109.3 & 2.4 & 112.1 & 10.6 & 97.5 \\
\hline P04U & $B-6^{2}$ & $8 / 19 / 02$ & 105.1 & 2.1 & 112.1 & 10.6 & 93.8 \\
\hline P04U & $A-7^{2}$ & $8 / 19 / 02$ & 104.6 & 2.5 & 112.1 & 10.6 & 93.3 \\
\hline P04U & $C-7$ & $8 / 19 / 02$ & 108.2 & 2.5 & 112.1 & 10.6 & 96.5 \\
\hline Average & & & 105.6 & 2.5 & & & 94.55 \\
\hline $\begin{array}{l}\text { Coefficent of } \\
\text { Variance }^{3}\end{array}$ & & & $2.5 \%$ & $21.2 \%$ & & & $2.3 \%$ \\
\hline
\end{tabular}

Notes:

$\left(\mathrm{lbs} / \mathrm{ft}^{3}\right)=$ pounds per cubic foot.

1 No test performed at grid station A-1 at P03U due to probe refusal on coarse rock and cobbles.

2 Probe driven less than 12 in due to condition of material at these stations.

3 Coefficent of Variance $=100$ (standard deviation/mean)percent

Source: BN Materials Testing Laboratory, Nuclear Density data report typed 9/23/02, in Characterization Report DOE/NV/11718758, Rev 1 (BN, 2005a)

In-place bulk density and percent compaction tests for 15 samples out of 16 collected between May 29, 2002, and July 3, 2002, from the P03U, P04U and T01U-T07U covers yielded results that were very consistent with the previous data. One of the 16 samples was not tested. Table 5-9 presents the in-place density, compaction, and calculated porosity results for the core samples. Inplace dry densities calculated from core samples were slightly lower than Proctor dry densities. Mean in-place dry density was $98.1 \mathrm{lbs} / \mathrm{ft}^{3}$, or $1.572 \mathrm{~g} / \mathrm{cm}^{3}$. Mean in-place saturated density was $1.933 \mathrm{~g} / \mathrm{cm}^{3}$. Mean moisture content was 5.6 percent by weight. Mean Proctor dry density was $111.6 \mathrm{lbs} / \mathrm{ft}^{3}$. Mean compaction was 87.9 percent. Variances in compaction and density results were less than 4 percent. 
Characterization Report 92-Acre Area

Section: Site Characteristics

Revision: 0

Date: June 2006

Table 5-9. Operational Covers - Bulk Density, Compaction, and Permeability

\begin{tabular}{|c|c|c|c|c|c|c|c|c|}
\hline $\begin{array}{l}\text { Sample Location } \\
\text { (cover, grid or } \\
\text { descriptive } \\
\text { location and } \\
\text { depth below } \\
\text { ground surface) }\end{array}$ & Date & $\begin{array}{c}\text { In-place Dry } \\
\text { Density } \\
\left(\text { (lbs/ft } \mathrm{ft}^{3}\right)\end{array}$ & $\begin{array}{c}\text { Proctor Dry } \\
\begin{array}{c}\text { Density } \\
\left.\text { (lbs/ft }{ }^{3}\right)\end{array} \\
\end{array}$ & \begin{tabular}{|c|} 
In-place Dry \\
Density \\
$\left(\mathrm{g}^{\prime} / \mathrm{cm}^{3}\right)$
\end{tabular} & $\begin{array}{c}\text { In-place } \\
\text { Saturated } \\
\text { Density } \\
\left(\mathrm{g} / \mathrm{cm}^{3}\right) \\
\end{array}$ & $\begin{array}{c}\text { Moisture } \\
\text { (percent g/g) }\end{array}$ & $\begin{array}{c}\text { Percent } \\
\text { Compaction }\end{array}$ & $\begin{array}{c}\text { Average } \\
\text { Permeability } \\
\text { (4-6 tests per } \\
\text { sample) } \\
(\mathrm{cm} / \mathrm{sec}) \\
\end{array}$ \\
\hline $\begin{array}{l}\text { P03U, by Location } \\
22,1 \text { foot }\end{array}$ & $5 / 29 / 02$ & 97.4 & 110.1 & 1.561 & 1.874 & 4.7 & 88.5 & 2.86E-03 \\
\hline $\begin{array}{l}\text { P03U, by Location } \\
22,3 \text { foot }\end{array}$ & $5 / 29 / 02$ & 94.1 & 110.1 & 1.507 & 1.918 & 5.2 & 85.5 & 3.26 E-03 \\
\hline P04U, B4, 1- foot & $5 / 29 / 02$ & 94.7 & 112.1 & 1.517 & 1.932 & 5.7 & 84.5 & 6.49E-03 \\
\hline P04U, B4, 3-foot & $5 / 29 / 02$ & 91.2 & 112.1 & 1.461 & 1.827 & 6.7 & 81.4 & $3.12 \mathrm{E}-03$ \\
\hline P04U, C10, 1-foot & $6 / 19 / 02$ & 98.5 & 109.8 & 1.578 & 1.934 & 6.4 & 89.7 & $1.88 \mathrm{E}-04$ \\
\hline P04U, C10, 3-foot & 7/3/02 & 101.0 & 109.8 & 1.618 & 1.939 & 6.3 & 92.0 & 3.72E-05 \\
\hline $\begin{array}{l}\text { T01U-T07U, F4, } \\
\text { 1-foot }\end{array}$ & $6 / 19 / 02$ & 97.6 & 113.1 & 1.564 & 2.057 & 5.1 & 86.3 & $1.33 \mathrm{E}-04$ \\
\hline $\begin{array}{l}\text { T01U-T07U, F4, } \\
\text { 3-foot }\end{array}$ & $6 / 19 / 02$ & 99.3 & 113.1 & 1.591 & 1.910 & 5.9 & 87.8 & 4.39E-04 \\
\hline $\begin{array}{l}\text { T01U-T07U, F7, } \\
\text { 1-foot }\end{array}$ & $6 / 25 / 02$ & NA & NA & NA & NA & NA & NA & NA \\
\hline $\begin{array}{l}\text { T01U-T07U, F7, } \\
\text { 3-foot }\end{array}$ & $6 / 25 / 02$ & 97.7 & 113.1 & 1.564 & 1.879 & 5.9 & 86.4 & 4.01E-04 \\
\hline $\begin{array}{l}\text { T01U-T07U, } \\
\text { D5,1-foot }\end{array}$ & $6 / 25 / 02$ & 102.7 & 113.1 & 1.645 & 1.991 & 5.8 & 90.8 & 6.68E-04 \\
\hline $\begin{array}{l}\text { T01U-T07U, D5, } \\
\text { 3-foot }\end{array}$ & 6/25/02 & 97.5 & 113.1 & 1.562 & 1.868 & 5.9 & 86.2 & 8.39E-04 \\
\hline $\begin{array}{l}\text { T01U-T07U,B4, } \\
\text { 1-foot }\end{array}$ & $7 / 3 / 02$ & 100.4 & 110.0 & 1.607 & 1.933 & 5.6 & 91.2 & 5.02E-04 \\
\hline $\begin{array}{l}\text { T01U-T07U, B4, } \\
\text { 3-foot }\end{array}$ & $7 / 3 / 02$ & 97.6 & 110.0 & 1.564 & 1.956 & 6.8 & 88.7 & $9.12 \mathrm{E}-03$ \\
\hline $\begin{array}{l}\text { T01U-T07U, B8, } \\
\text { 1-foot }\end{array}$ & $7 / 3 / 02$ & 106.1 & 112.4 & 1.699 & 2.079 & 3.6 & 94.4 & 7.65E-04 \\
\hline $\begin{array}{l}\text { T01U-T07U, B8, } \\
\text { 3-foot }\end{array}$ & $7 / 3 / 02$ & 96.2 & 112.4 & 1.542 & 1.900 & 4.6 & 85.6 & 5.94E-04 \\
\hline Average & & 98.1 & 111.6 & 1.572 & 1.933 & 5.6 & 87.9 & 1.96E-03 \\
\hline $\begin{array}{l}\text { Coefficient of } \\
\text { Variation }\end{array}$ & & $3.7 \%$ & $1.3 \%$ & $3.65 \%$ & $3.51 \%$ & $15.3 \%$ & $3.8 \%$ & $135.53 \%$ \\
\hline
\end{tabular}

Sources:

BN Materials Testing Laboratory data report typed 8/13/02 for tests performed 7/8/02 to 7/18/02, in Appendix B-3 NNSA report DOE/NV/11718 758, Rev 1 (BN, 2005d).

Undated BN Materials Testing Laboratory data report for ASTM D 2434-68 (re-approved 1974) permeability tests performed 7/15/02 to 7/29/02. This lab report is in Appendix B-7 of NNSA report DOE/NV/11718-758, Rev 1 (BN, 2005d). 
Table 5-10 also shows permeability data from the three unclassified landfill covers. Permeabilities for the 15 core samples tested ranged from $3.72 \mathrm{E}-05$ to $9.12 \mathrm{E}-03 \mathrm{~cm} / \mathrm{sec}$ with a mean of $1.96 \mathrm{E}-03 \mathrm{~cm} / \mathrm{sec}$. Four to six tests were run for each sample. Consistency between test runs for each sample was very high. Variability in permeability values between sample locations was much greater, but the permeability values found are typical of sands and silty sands, indicating consistency with soil texture data from the sieve analyses. The detailed data are in the undated lab report presented in Appendix B-7 of the Characterization Report (BN, 2005d).

Core samples collected from the same 16 locations at Pit 3, Pit 4 and T01U-T07U were evaluated at Daniel B Stephens \& Associates Laboratory for initial moisture content, dry bulk density, and wet bulk density. Table 5-10 summarizes the data. The data from the two laboratories for the splits were fairly consistent. The average dry bulk density calculated from results from the Daniel B. Stephens \& Associates lab data was $1.55 \mathrm{~g} / \mathrm{cm}^{3}$ compared to $1.572 \mathrm{~g} / \mathrm{cm}^{3}$ from the BN lab data. The average moisture content reported for samples sent to Daniel B Stephens \& Associates on a volume basis was slightly higher than the moisture contents for the samples sent to BN Materials Testing Laboratory reported on a weight basis.

Table 5-10 also summarizes calculated porosities. Porosities of the core samples ranged from 37.3 percent to 47.3 percent with a mean of 41.6 percent and a coefficient of variance of only 5.4 percent.

A constant head analysis of a soil core sample collected from somewhere in the 1 foot to 2.5 foot depth interval at grid point \#F7 in the operational cover over the T01U-T07U cells yielded a saturated conductivity value of $5.4 \mathrm{E}-05 \mathrm{~cm} / \mathrm{sec}$.

According to BN (2005d), comparison of these new physical properties and hydrogeologic data to previous values obtained for alluvium under the Area 5 RWMS (REECo, 1993a, b; Blout et al., 1995; Levitt et al., 1996) indicates that both data sets are similar.

The Characterization Report (BN, 2005d) contains copies of the laboratory and survey reports, including: operation cover core sample data; nuclear density data test point survey maps for P04U, P03U, T01C-T06C and T01U-T07U; nuclear density lab test results; bulk density, percent compaction and moisture content data; specific gravity data, proctor tests to determine maximum density at optimum moisture content; sieve analysis results for classification of the cover soil; permeability data from constant head tests on core samples; and plots of relative hydraulic conductivity versus pressure head. The laboratory reports provide more detail than summarized herein, including some Quality Assurance/Quality Control information, and the methods used.

The Characterization Report (BN, 2005d) also contains a topographic map. A topographic survey was completed in FY 2002 to document the configuration of the Area 5 RWMS (92-Acre Area) prior to any changes that might be made to the closure covers and intervening areas, inclusive of the GCD boreholes, from the time of the survey up to development of final covers for closure of the area. 
Table 5-10. Operational Covers - Porosity

\begin{tabular}{|c|c|c|c|c|c|c|}
\hline $\begin{array}{l}\text { Sample Location } \\
\text { (Cover, grid or } \\
\text { descriptive } \\
\text { location) }\end{array}$ & $\begin{array}{l}\text { Depth } \\
\text { (feet) }\end{array}$ & $\begin{array}{l}\text { Gravimetric } \\
\text { Moisture } \\
\text { Content } \\
\text { (Percent g/g) }\end{array}$ & $\begin{array}{c}\text { Volumetric Water } \\
\text { Content } \\
\left.\text { (Percent } \mathrm{cm}^{3} / \mathrm{cm}^{3}\right)\end{array}$ & $\begin{array}{l}\text { Dry Bulk } \\
\text { Density } \\
\left(\mathrm{g} / \mathrm{cm}^{3}\right)\end{array}$ & $\begin{array}{l}\text { Wet Bulk } \\
\text { Density } \\
\left(\mathrm{g} / \mathrm{cm}^{3}\right)\end{array}$ & $\begin{array}{c}\text { Calculated } \\
\text { Porosity } \\
\text { (Percent) }\end{array}$ \\
\hline P03U, by tube 22 & 1 & 5.6 & 8.8 & 1.58 & 1.67 & 40.4 \\
\hline P03U, by tube 22 & 3 & 6.7 & 10.3 & 1.53 & 1.63 & 42.2 \\
\hline P04U, B4 & 1 & 6.0 & 9.5 & 1.59 & 1.69 & 39.8 \\
\hline P04U, B4 & 3 & 7.4 & 11.4 & 1.53 & 1.64 & 42.3 \\
\hline P04U, C10 & 1 & 7.0 & 10.9 & 1.55 & 1.66 & 41.6 \\
\hline P04U, C10 & 3 & 6.6 & 10.6 & 1.61 & 1.72 & 39.3 \\
\hline T01U-T07U, F4 & 1 & 5.8 & 9.0 & 1.53 & 1.62 & 42.1 \\
\hline T01U-T07U, F4 & 3 & 6.4 & 10.3 & 1.60 & 1.70 & 39.6 \\
\hline T01U-T07U, F7 & 1 & 6.7 & 10.5 & 1.56 & 1.67 & 41.0 \\
\hline T01U-T07U, F7 & 3 & 5.1 & 8.4 & 1.66 & 1.74 & 37.3 \\
\hline T01U-T07U, D5 & 1 & 6.1 & 9.2 & 1.51 & 1.61 & 42.9 \\
\hline T01U-T07U, D5 & 3 & 6.4 & 10.0 & 1.56 & 1.66 & 41.1 \\
\hline T01U-T07U,B4 & 1 & 5.9 & 8.8 & 1.49 & 1.57 & 43.9 \\
\hline T01U-T07U, B4 & 3 & 6.8 & 10.3 & 1.51 & 1.61 & 43.0 \\
\hline T01U-T07U, B8 & 1 & 3.8 & 5.8 & 1.54 & 1.60 & 42.0 \\
\hline T01U-T07U, B8 & 3 & 4.7 & 6.6 & 1.40 & 1.46 & 47.3 \\
\hline Average & & 6.1 & 9.4 & 1.55 & 1.64 & 41.6 \\
\hline $\begin{array}{l}\text { Coefficient of } \\
\text { Variation }\end{array}$ & & $15.2 \%$ & $16.1 \%$ & $3.8 \%$ & $4.0 \%$ & $5.4 \%$ \\
\hline
\end{tabular}

Notes:

$\mathrm{g} / \mathrm{cm}^{3}=$ grams per cubic centimeter

Source:

Daniel B. Stephens \& Associates, Inc., lab report, no date, in Appendix B-3 of the NNSA report

DOE/NV/11718 - 758, Rev 1 (BN, 2005d). 
Characterization Report 92-Acre Area

Section: Site Characteristics

Revision: 0

Date: June 2006

This page intentionally left blank 


\subsection{CONCEPTUAL MODELS AND ASSESSMENTS}

Many models have been developed that have application to the characterization and assessment of the Area 5 RWMS. Some are quite specific and address a single factor, and others are more complex, addressing numerous aspects of the total disposal system and environment. Examples include:

- Hydrogeologic (IT, 1998, 1999ab; Blout et al., 1995; Laczniak et al., 1996; Winograd and Thordarson, 1975)

- Unsaturated Flow (Dixon, 1999; BN, 1998a)

- Groundwater Recharge (Levitt and Yucel 2002a, b; Hokett and French, 1998)

- $\quad$ Subsidence (DOE, 1998; Obi et al., 1996)

- $\quad$ Source Term (Shott et al., 1998)

- $\quad$ Transport and Exposure (Cochran, Crowe, et al., 2001a; Estrella, 1994)

- Inadvertent Human Intrusion (BN, 2001; Black, 2001; Shott et al., 1998)

- Biological (Hansen and Ostler, 2003; Winkel et al., 1995; Wirth et al., 1999)

- General Performance Assessment (Shott et al., 1998; Levitt et al., 1999; Cochran, Beyeler, et al., 2001)

Most scenarios for radionuclide release and transport ultimately involve some aspect of the hydrologic system. Additionally, the hydrologic environment affects monitoring, PA, and closure cover design decisions. The hydrologic conceptual model for the Area 5 RWMS, the PA, and the Composite Analysis are described below.

\subsection{Hydrologic Conceptual Models for the AREA 5 RWMS}

Climate and vegetation strongly control the movement of water in the upper few meters of the alluvium. The magnitude and direction of both liquid and vapor fluxes vary seasonally and often daily. Except for periods following precipitation events, the moisture content in this near-surface zone is quite low. Below the near-surface region is an area where relatively steady upward movement of water is occurring. In this zone of slow upward moisture movement, analyses of stable isotope compositions of soil pore water confirm that evaporation is the dominant process (Tyler et al., 1996). This zone extends to depths as great as 3 to $40 \mathrm{~m}$ (10 to $131 \mathrm{ft}$ ) in Area 5.

Below this zone, water-potential measurements indicate the existence of a static zone, which is approximately 40 to $90 \mathrm{~m}$ (131 to $295 \mathrm{ft}$ ) below the ground surface at well UE5PW-1 in Area 5 (Shott et al., 1998). In this static zone, essentially no vertical liquid flow is currently occurring. Below this static zone, flow is quasi-steady-state and downward due to gravity. Stable isotope compositions of pore water from these depths indicate that infiltration into this zone occurred under cooler, past climatic conditions (Tyler et al., 1996).

See Figure 6-1 for a diagram of the vadose zone hydrologic conceptual model at the Area 3 and Area 5 RWMS, as well as Figure 5-14 from Section 5.6.6. 
Characterization Report 92-Acre Area

Section: Conceptual Models and Assessments

Revision: 0

Date: June 2006

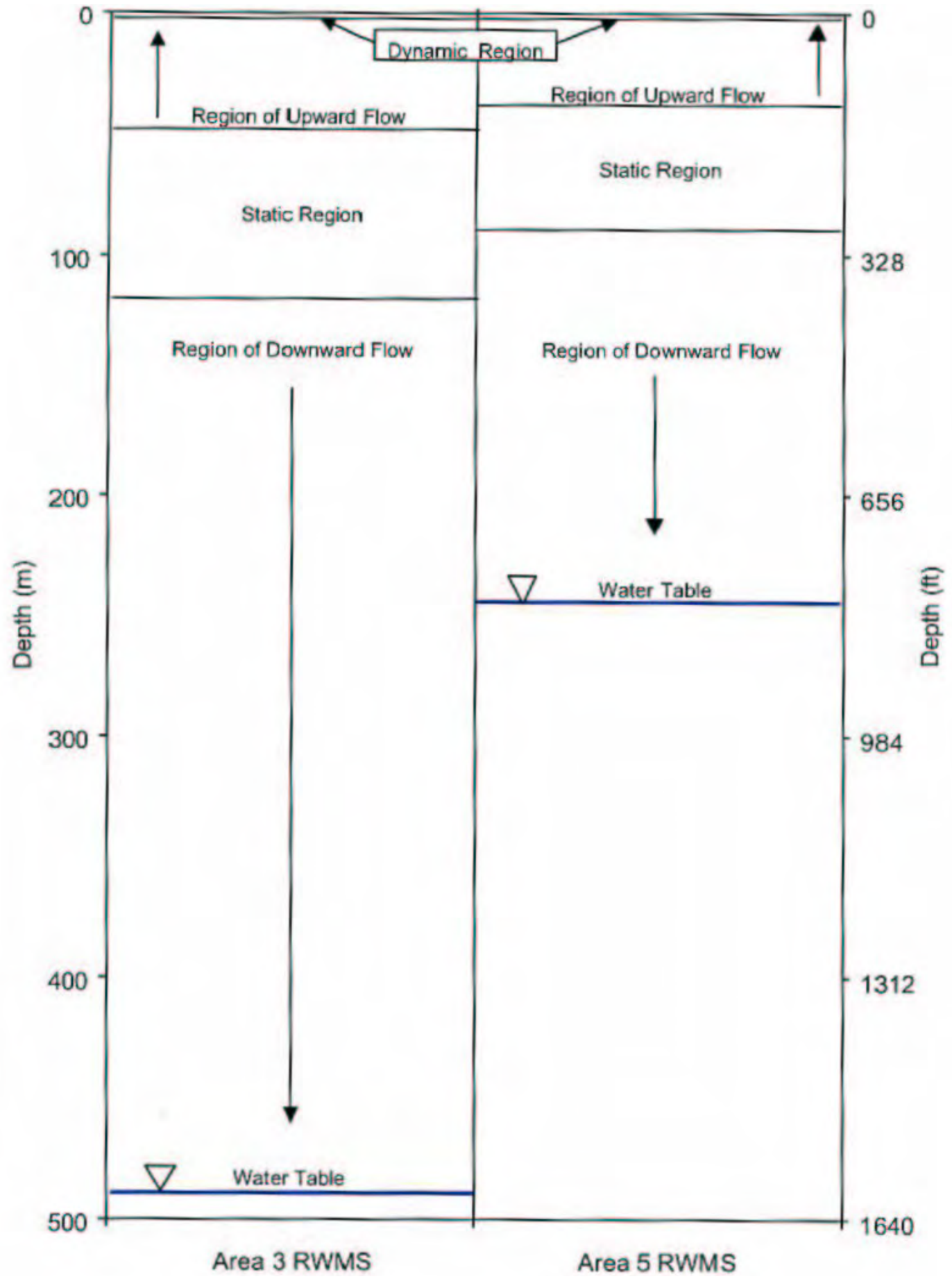

Figure 6-1. Vadose Zone Hydrologic Conceptual Model of the Area 5 Radioactive Waste Management Site Source: BN (2005a)

Results of the extensive research, field studies, modeling efforts, and monitoring data summarized in the Area 5 Performance Assessment (Shott et al., 1998), in Levitt et al. (1999, 1998), and in Levitt and Yucel (2002a, 2002b) suggest the potential for recharge is negligible. 
Lysimeter studies indicate that under bare-soil conditions such as those found at the operational waste cell covers, some drainage may eventually occur through the operational waste covers into the waste zone. This drainage is estimated to be about 1 percent of the annual rainfall at Area 5, based on conservative one-dimensional modeling results (Levitt et al., 1998, 1999).

In the unlikely event that water would migrate below the current static zone, movement to the aquifer would be extremely slow due to the low water content of the alluvium. An unsaturated flow model was used to predict estimated travel times for the unretarded movement of water from the bottom of the static zone to the capillary fringe zone of the groundwater table in the uppermost aquifer. The model used Area 5 rainfall data from 1980 to 1993 to help define the upper boundary conditions, hydrological parameter data from the Science Trench Borehole project, and alluvium layer thickness and hydraulic property variation data from Snyder and Gustafson (1994) and other Area 5 characterization work to define the conditions. Two cases were evaluated, one where all the alluvial layers had a constant thickness, and one to capture the variations in grain-size distributions and measured hydrologic parameters through the vadose zone profile. Shott et al. (1988) reported that after applying statistics to 7500 model realizations for each case, the mean travel time was over 55,000 years for both cases. The modelers concluded that there is a 95 percent probability that the travel time (under the assumption that horizontal layer thickness is uniformly distributed between 0.6 and $2.6 \mathrm{~m} \mathrm{[1.9}$ and $8.5 \mathrm{ft}]$ ) is between 31,795 to 101,944 years.

Given the lysimeter data that indicates less than 1 percent of precipitation is thought to make it down to $2 \mathrm{~m}$ (much less below the static zone which extends to from 40 to $90 \mathrm{~m}$ [131 to $295 \mathrm{ft}$ ] below the ground surface at UE5PW-1), and the modeled slow travel rates, no recharge is occurring within the vicinity of the Area 5 RWMS under current climatic conditions.

Even if sufficient water could get into the waste to create a leachate contaminated with radionuclides, and if recharge were to occur, significant decay would occur over the thousands of years required to reach the groundwater. Groundwater is therefore an unlikely pathway of contaminant transport with respect to the shallow waste cells of the Area 5 RWMS.

More recent vadose zone studies by Walvoord, Plummer, et al. (2002) and Walvoord, Phillips, et al. (2002) support and extend the conceptual moisture and contaminant transport vadose zone model for the Area 5 RWMS. Wolfsberg and Stauffer (2003) refined estimates of upward liquid flux and confirmed they are low.

The conceptual model for radionuclide transport and release at the Area 5 RWMS therefore focuses on the upward transport of soluble radionuclides by liquid advection and diffusion with retardation, the movement of soluble and particulate radionuclides by plants and burrowing animals, and the movement of gaseous radionuclides by diffusion with the liquid phase.

The PA model incorporates the hydrological and contaminant transport conceptual models to evaluate potential exposures of people to contaminants in the future under various land use and inadvertent intrusion scenarios. 


\subsection{Performance Assessment and Composite Analysis}

A PA is a systematic analysis of potential risks, and includes a comparison of those risks to the established performance objectives. A PA is conducted to provide the NNSA/NSO with reasonable expectation that disposal of LLW will meet radiological performance objectives for long-term protection of the public and the environment, as established in DOE Manual (M) 435.1-1. Regulated LLW under DOE O 435.1 is limited to waste disposed from September 26, 1988, to the assumed closure date.

Composite Analyses (CA) are planning tools used by the NNSA/NSO to ensure that the combined effect of all sources of residual radioactive material that could contribute to the dose calculated from disposal facilities will not compromise requirements for future radiological protection of the public and environment. The CA takes into account all potential sources including the waste deposited before September 26, 1988, and any classified materials. Potential sources of contaminants in the vicinity of the Area 5 RWMS considered for the Area 5 RWMS CA included the:

- Frenchman Flat UGTA,

- Frenchman Flat Playa soil site which is an area of soil contaminated by historic atmospheric nuclear weapons tests,

- GMX soil site which is an area of plutonium-contaminated soil created by historic non-nuclear detonations of nuclear weapons components.

Annual reviews of the adequacy of the PAs and CAs are recommended under the Maintenance Plan for the Performance Assessments and Composite Analyses for the Area 3 and Area 5 Radioactive Waste Management Sites at the Nevada Test Site (BN, 2000a). They are required under the Disposal Authorization Statement for the Department of Energy Nevada Operations Office Nevada Test Site Area 5 Radioactive Waste Management Site (DOE, 2000a). These annual reviews and resulting reports provide interim updates between PA and CA document revisions and progress on meeting conditions and provisions in the Disposal Authorization Statement (DAS). Addendum reports to the PA and CA have also been issued (BN, 2001a, 2001b). The process of review and revision ensures that the analyses intended to ensure protection of the public and environment are conducted with the best data available at the time.

Monitoring during operation of a facility, closure of that facility, and monitoring after closure are inextricably tied to the PA and CA. The PA and CA provide information useful for designing a monitoring plan and for determining the best method of closure to realize radiological protection of the public and environment. Conversely, results obtained through monitoring are part of the data needed to revise the PA and CA. Documents related to the PA and CA and to the ICMP (BN, 2005a) include the Auditable Safety Analysis (BN, 2000b), the NTSWAC

(NNSA/NSO, 2005), and the RREMP (BN, 2003a).

A PA and a CA have been completed for the Area 5 RWMSs (Shott et al., 1998; BN, 2001c). The PA was reviewed and approved, with conditions, by DOE/Headquarters in 1996. A conditional DAS (DOE, 2000a) was issued for the Area 5 RWMS in FY 2001 following the review of the CA. The DAS conditions were removed in May 2002 with acceptance of the PA addendum (BN, 
2001a). Another PA was completed specifically for the TRU material placed in four GCD boreholes (Cochran, Beyeler, et al., 2001).

In the PA of the Area 5 RWMSs (Shott et al., 1998), the analyses assumed that the closure cover would consist of native alluvium, with its thickness corresponding to the thickness of the operational cover. The hydrogeologic properties of the cover material used in the models were based on results of field and laboratory tests. The assessments were done under closure conditions that were assumed to be more adverse than would likely occur. In the Area 5 RWMS $\mathrm{PA}$, as a base case, the closure cover was assumed not to subside. As a worst case, the closure cover was assumed to thin, crack, and subside below grade. Performance objectives and results of modeling conducted for the PA are shown in Table 4.2 of the Integrated Closure and Monitoring Plan (BN, 2005a). Based on these analyses, the Area 5 RWMS meets performance objectives by a wide margin. The dose from all interacting sources to a member of the public is calculated for the Area 5 RWMSs to be $7 \mathrm{mrem} / \mathrm{yr}$. The CA performance objective is $100 \mathrm{mrem} / \mathrm{yr}$ (BN, 2005a).

The PA evaluates the potential exposures to people in the future for various land-use scenarios including recreation, ranching, and a non-commercial farmer residing at the NTS boundary. Land-use plans and use restrictions are assumed to prohibit construction and well drilling within the site boundaries in perpetuity, but if administrative restrictions are ineffective, the PA also models inadvertent intrusions in the landfill area, resulting in exhumed contaminants and residency in the resulting contaminated area. The scenarios include excavation to construct a house and drilling to install a well. Modeling results indicate potential doses to a member of the public at the relevant points of compliance for each pathway and the scenario met the performance objectives by wide margins. The Area 5 RWMS also achieves the intruder protection, radon flux density, and groundwater protection objectives by wide margins.

Progress on the conversion and integration of the approved Area 5 RWMS PA model into a probabilistic, dynamic modeling platform using Golder Associates GoldSim ${ }^{\circledR}$ computer code is presented in the 2002 Annual Summary Report (BN, 2003c). Addendum 2 of the Area 5 RWMS PA is scheduled to be published in Fiscal Year 2006 and will include:

- $\quad$ Presentation of results of the Area5 RWMS goldsim ${ }^{\circledR}$ model with updated input parameter distributions and processes; updated closure inventory estimates; and

- Modifications to address the reduction of the regulatory compliance period from 10,000 to 1,000 years to be consistent with the latest DOE guidance (DOE O 435.1 which superseded O 5820.2A).

Monitoring results continue to support PA assumptions and models. The biotic transport model has been refined with the results of new more-detailed studies of plant rooting and animal burrowing characteristics. Site-specific measurements of the Radon-222 effective diffusion coefficient in cover material have also been incorporated in the model. Preliminary data suggests Addendum 2 of the PA will demonstrate that the Area 5 RWMS continues to meet all performance objectives by wide margins.

The DOE Office of Site Closure and the DOE Office of Environment also approved the PA report for TRU material in four GCD boreholes (Cochran, Beyeler, et al., 2001) on the 
recommendation of the Transuranic Waste Disposal Facility Federal Review Group (DOE Memorandum, February 5, 2002). In the GCD PA, future inadvertent exposure scenarios modeled included an off-site resident farmer and an on-site homebuilder who drills a groundwater well through a GCD borehole location. The model took into account many transport processes including dissolution, precipitation, reversible chemical sorption onto soil, advection, diffusion, dispersion, radioactive decay, plant uptake, and bioturbation. Calculated potential whole body and lung radiation doses for all scenarios were far below regulatory limits. One model scenario included both the TRU material and the other non-TRU material disposed in GCD boreholes GCD-01C, GCD-02C, GCD-03C and GCD-04C.

The GCD PA also evaluated potential effects of subsidence and climate change to a wetter and cooler glacial climate. The PA concluded that even if subsidence and a glacial climate began just 170 years from now, surface water would not infiltrate and reach the groundwater table in 10,000 yrs (Cochran, Beyeler, et al., 2001).

The purpose of the CA is to determine if continuing operation of the Area 5 RWMS poses an acceptable risk to the public considering the total waste inventory and all other interacting sources of radioactive material in the vicinity. The CA for the Area 5 RWMS indicates the combined TEDE for the Area 5 RWMS and the three contaminated soil sites in Frenchman Flat will be far below the 100 mrem dose limit throughout the 1,000-yr compliance period. If land use controls are assumed to be effective at limiting the groundwater dose from the Frenchman Flat UGTA, the combined TEDE for the Area 5 RWMS and the three contaminated soil sites will also remain below the 30mrem dose constraint throughout the 1,000-yr compliance period. 1,000 yrs from now, the annual TEDE for a future resident of the Area 5 RWMS is estimated to be 1 mrem. The highest TEDE for an individual source, 6 mrem per year, is expected at the GMX soil site at 250 years after closure. These doses change very little from 250 to 1000 yrs after closure (BN, 2001c).

An Addendum to the CA (BN, November 2001b) provided “Supplemental Information” in response to comments generated during DOE Headquarters review of the CA. The "Supplemental Information" was reviewed and accepted by the Low-Level Waste Disposal Facility Federal Review Group, known as LFRG. Much of the requested information consisted of clarifications. The Addendum also presents a crosswalk of the PA and CA models for both the Area 3 and the Area 5 RWMSs which was used primarily to address questions regarding consistency of models and model parameter values. The Addendum also expanded the discussion of how DOE addresses maintaining doses ALARA at the NTS, and refers to the ALARA analysis presented in the PA. The cost-benefit analysis indicated that the only significant radiation exposure to an individual or population in the Frenchman Flat Basin can occur as the result of the loss of institutional control, and that there are no cost-effective alternatives in the Area 5 operation which would result in a significantly lower individual or population dose (BN, 2001b). 


\subsection{CLOSURE PLANNING}

\subsection{Regulatory CONTEXT}

The current DOE Order governing management of radioactive waste is 435.1 (DOE, 1999). Closure standards are presented in DOE Order 435.1, Title 40 CFR 265, Title 40 CFR 191, NAC 444.743, and RCRA requirements as incorporated in NAC 444.8632. Monitoring standards are included in DOE Order 435.1, DOE Order 450.1, Title 40 CFR 61, Title 40 CFR 264, Title 40 CFR 265, and Title 40 CFR 191. A summary of the key requirements is in the ICMP (BN, 2005a).

\subsection{EXISTING SUPPORTING DOCUMENTS}

The DOE M 435.1 and DOE Guidance 435.1-1, which specifies that preliminary closure and monitoring plans for a LLW management facility be developed and initially submitted with the PA and CA for that facility are associated with the DOE Order 435.1. Development of these plans is also a condition of the Disposal Authorization Statements issued for the Area 5 RWMS. Key documents in place for the Area 5 RWMS include the following:

- $\quad$ PA for the Area 5 RWMS at the NTS, Nye County, Nevada, Revision 2.1 (Shott et al., 1998). The second addendum to the PA is due out in Fiscal Year 2006.

- Composite Analysis for the Area 5 RWMS at the NTS, Nye County, Nevada (BN, 2001c).

- Consequences of Subsidence for the Area 3 and Area 5 RWMSs, Nevada Test Site (DOE, 1998).

- Integrated Closure and Monitoring Plan for the Areas 3 and 5 RWMSs at the NTS (BN, June 2005a).

- Disposal Authorization Statement for the DOE/NV NTS Area 5 RWMS (DOE, 2000a).

- $\quad$ NTSWAC, Revision 6 (NNSA/NSO, 2005a).

The previous characterization report, Characterization Report, Operational Closure Covers for the Area 5 Radioactive Waste Management Site at the Nevada Test Site, DOE /NV/11718 - 758, Rev. 1 (BN, 2005d) includes an annotated bibliography of selected references relevant to the characterization and closure of the Area 5 RWMS, an extensive photo log, and the analytical reports for a 2002 evaluation of the properties of the operational closure covers. This report supplements the previous report with a focus on summarizing characteristics affecting future potential water and contaminant transport and is in a format similar to the FFACO CAU 110 Characterization Report.

The ICMP (BN, 2005a) for closing and monitoring both RWMSs was developed in 2001, and revised in 2005. The ICMP defines the approach and schedule for both closing and monitoring the Area 3 RWMS and Area 5 RWMS sites. The closure and monitoring plans were integrated for efficiency because much of the information that would be included in individual plans is the same. 
The conceptual closure approach consists of ensuring that the performance of the actual cover at least meets that modeled in the PAs. The actual cover will be vegetated monolayer, using evapotranspiration, with the monolayer comprised of native alluvium. Throughout a period of active institutional control, the cover will be maintained at its proper thickness by infilling subsided areas and cracks. Performance of the cover will be monitored at a frequency and for a period to be determined based on observed trends in monitoring data.

A single cover and post-closure monitoring program can be developed that meets the needs of all of the disposal units within the 92-Acre Area of the Area 5 RWMS. The regulatory status and closure requirements for each unit depend on the type of waste, when it was disposed, and permitting. Closure units have been defined for subsets of the waste disposal units based on waste type and regulatory status. Each closure unit will be closed in accordance with the pertinent requirements.

\subsection{Anticipated Schedule}

Activities associated with final closure of the 92-Acre Area of the Area 5 RWMS started in FY 2005 and are anticipated to be completed by FY 2011. Activities associated with final closure of the Area 5 RWMS Expansion Area are expected to begin in FY 2019 and be completed in FY 2021. Final closure activities at the Area 3 RWMS are expected between FY 2006 and FY 2008. 


\subsection{WORK IN PROGRESS}

There are several ongoing monitoring programs and planned studies that will provide additional characterization data in the near future. The anticipated data will primarily support compliance and PAs. The existing body of site characterization data collected over the past three decades provides ample basis for closure planning at the Area 5 RWMS.

New products expected by the end of FY 2005, concurrent with the development of this document, include the formal publication of key characterization reports for the Area 5 RWMS originally prepared by NNSA contractors. Five reports relevant to the Area 5 RWMS were reviewed and revised to bring them up to current DOE publication standards. The reports which entered the DOE Scientific and Technical Information Product review process in FY 2005 are listed in Table 8-1. Several of these have been referenced in this report.

Table 8-1. Updated Documents

\begin{tabular}{|l|c|}
\hline \multicolumn{1}{|c|}{ Document } & \multicolumn{1}{|c|}{$\begin{array}{c}\text { NNSA Document } \\
\text { Identification }\end{array}$} \\
\hline \hline $\begin{array}{l}\text { BN, 2005a: Integrated Closure and Monitoring Plan for the Area 3 } \\
\text { and Area 5 Radioactive Waste Management Sites at the Nevada Test } \\
\text { Site }\end{array}$ & DOE/NV/11718--449-Rev 2 \\
\hline $\begin{array}{l}\text { BN, 2005d: Re-release of BN ,2002: Characterization Report } \\
\text { Operational Closure Covers for the Area 5 Radioactive Waste } \\
\text { Management Site at the Nevada Test Site }\end{array}$ & DOE/NV/11718--758- Rev 1 \\
\hline $\begin{array}{l}\text { BN, 2005: Re-release of Lee, YJ; Van Remortel, RD; Snyder, KE } \\
\text { (1996): Soil Characterization Database for the Area 5 Radioactive } \\
\text { Waste Management Site, Nevada Test Site, Nye County, Nevada }\end{array}$ & DOE/NV/11718--1014 \\
\hline $\begin{array}{l}\text { BN, 2005g: Re-release of REECo (1994): Hydrogeologic } \\
\text { Characterization Data from the Area 5 Shallow Soil Trenches, } \\
\text { Nevada Test Site, Nye }\end{array}$ & DOE/NV/11718--1060 \\
\hline $\begin{array}{l}\text { BN, 2005e: Combined re-release of REECo (1994): Site } \\
\text { Characterization and Monitoring Data from Area 5 Pilot Wells, } \\
\text { Nevada Test Site, Nye County, Nevada and REECo (1993): Site } \\
\begin{array}{l}\text { Characterization and Monitoring Data from Area 5 Pilot Wells } \\
\text { Nevada Test Site Nye County, Nevada. Appendices A through I }\end{array}\end{array}$ \\
\hline
\end{tabular}

New products expected by the end of FY 2006 include:

- An addendum updating the PA.

- An annual data report for the Area 5 RWMS Groundwater Monitoring Program.

- An annual data report for the Waste Management Monitoring Program which summarizes radiation exposure, air quality, groundwater, meteorology, vadose zone, biota tritium, and cover subsidence monitoring data for both the Area 3 and Area 5 RWMS.

- A report on the historic waste inventory records. 
Characterization Report 92-Acre Area

Section: Work In Progress

Revision: 0

Date: June 2006

This Page intentionally left blank 


\subsection{CONCLUSIONS AND RECOMMENDATIONS}

\subsection{Conclusions}

Much characterization, environmental monitoring, and transport modeling work has been performed in the vicinity of the Area 5 RWMS over the past several decades to assess facility performance. The potential pathways for contaminant transport have been well defined. The results show the potential for release and transport of radionuclides from the waste facility is very low. The natural setting restricts potential movement of contaminants with minimum controls.

Although most of the radioactive inventory is relatively immobile, there is some tritium, a volatile radionuclide that can readily move with water. Tritium should continue to be closely monitored, particularly in the vicinity of GCD-05U, the main tritium waste disposal cell. The current monitoring program consists of periodic monitoring of soil gas, air moisture, and biota, and is adequate to catch any release of tritium in a timely manner.

The quality of waste tracking has improved over time, as operational needs and regulations became more stringent. Current waste-tracking systems are very detailed and accurate. Although the historic public unclassified waste records are not complete, much about the nature of the waste is known from process data. The nature of the waste is adequately defined to safely close the site without further assessment.

This characterization work and the PAs completed to date indicate that the regulatory performance objectives for the closure of the Area 5 RWMS have been and will continue to be met. The existing monitoring programs should be continued and reevaluated as needed under the PA.

\subsection{Recommendations}

- Continue with site monitoring and reporting activities.

- $\quad$ Proceed with development of the Closure Plans for the Area 5 RWMS. 
Characterization Report 92-Acre Area

Section: Conclusions and Recommendations

Revision: 0

Date: June 2006

This Page intentionally left blank 


\subsection{REFERENCES}

Albright, W., S. Tyler, J. Chapman, M. Miller, R. Estrella, 1994. Area 5 Site Characterization Project Report FY 1994. DOE/NV/10845-T20. Desert Research Institute, Las Vegas, Nevada.

Allred, D. M., D. M. Beck, and C. D. Jorgensen, 1963. "Biotic Communities of the Nevada Test Site.” Brigham Young University Science Bulletin, Biological Series 2(2), No. 2.

Angerer, J. P., W. K Ostler, W. D. Gabbert, and B.W. Schultz, 1994. Secondary Succession of Disturbed Sites at Yucca Mountain, Nevada. EG \& G Energy Measurements, Inc., Las Vegas, Nevada. December 1994.

Barker, L., 1997. Alternative Evaluation Study: Methods to Mitigate/Accommodate Subsidence for the Radioactive Waste Management Sites at the Nevada Test Site, Nye County, Nevada, with Special Focus on Disposal Unit U-3ax/bl. Bechtel Nevada, Las Vegas, Nevada. September 1997.

Barker, L. E., G. J. Shott, P. K. Black, B. A. Moore, and S. E. Rawlinson, 1998. Performance Assessment of the Area 5 RWMS at the NTS, Nye County, Nevada: Update of Scenarios and Waste Acceptance Criteria Through the Performance Assessment Maintenance Program. DOE/NV/11718--177. Bechtel Nevada, Las Vegas, Nevada. February 1998.

Battis, J. D., 1978. “Geophysical Studies for Missile Basin; Seismic Risk Studies in the Western United States.” TI-ALEX (02) FSR-78-01. Texas Instruments, Inc., Houston, Texas.

Beatley, J. C., 1976. Vascular Plants of the Nevada Test Site and Central-Southern Nevada. TID-26881. NTIS, U.S. Department of Commerce, Springfield, Virginia.

Beatley, J. C., 1969. “Biomass of Desert Winter Annual Plant Populations in Southern Nevada.” Oikos, 20:261-274.

Bechtel Nevada, 2005a. Integrated Closure and Monitoring Plan for the Area 3 and Area 5 Radioactive Waste Management Sites at the Nevada Test Site. DOE/NV/11718--449-Rev2. Las Vegas, Nevada. June 2005. , 2005b. Low-Level Waste Inventory System User’s Guide. Las Vegas, Nevada. March 2005. , 2005c. Nevada Test Site 2004 Waste Management Monitoring Report, Area 3 and Area 5 Radioactive Waste Management Sites. BN-NTS-05-0025. Las Vegas, Nevada. June 2005. , 2005d. Characterization Report: Operational Soil Covers for the Area 5 Radioactive Waste Management Sites at the Nevada Test Site. DOE/NV/11718--758, Rev. 1. Las Vegas, Nevada. June 2005. , 2005e. Site Characterization and Monitoring Data for the Area 5 Pilot Wells, Nevada Test Site, Nye County, Nevada. DOE/NV/11718--1067. Las Vegas, Nevada. September 2005. 
_ 2005f. A Hydrostratigraphic Model and Alternatives for the Groundwater Flow and Contaminant Transport Model of Corrective Action Unit 98: Frenchman Flat, Nye County, Nevada. DOE/NV/1171--1064. Las Vegas, Nevada. September 2005. , 2005g. Hydrogeologic Characterization Data for the Area 5 Shallow Soil Trenches, Nevada, Nevada Test Site, Nye County, Nevada. DOE /NV/11718--1060.

Las Vegas, Nevada. July 2005. , 2005h. Nevada Test Site 2004 Data Report: Groundwater Monitoring Program, Area 5 Radioactive Waste Management Site. DOE/NV/11718--1015. Las Vegas, Nevada. February 2005. , 2005i. Soil Characterization Database for the Area 5 Radioactive Waste Management Site, Nevada Test Site. DOE/NV/11718--1014. Las Vegas, Nevada. January 2005. , 2004a. Nevada Test Site Environmental Report 2003. DOE NV 11718--971. Las Vegas, Nevada. October 2004.

—_, 2004b. Nevada Test Site 2003 Data Report: Groundwater Monitoring Program, Area 5 Radioactive Waste Management Site. DOE/NV/11718--894. Las Vegas, Nevada. February 2004.

_ 2004c. Nevada Test Site 2003 Waste Management Monitoring Report: Area 3 and Area 5 Radioactive Waste Management Sites, Nevada Test Site. DOE/NV/11718--930. Las Vegas, Nevada. June 2004.

__ 2003a. Nevada Test Site Routine Radiological Environmental Monitoring Plan. DOE/NV/11718--804. Las Vegas, Nevada. June 2003. , 2003b. 2002 Data Report: Groundwater Monitoring Program, Area 5 Radioactive Waste Management Site. Las Vegas, Nevada. February 2003. , 2003c. 2002 Annual Summary Report for the Area 3 and Area 5 Radioactive Waste Management Sites at the Nevada Test Site, Nye County, Nevada, Review of the Performance Assessments and Composite Analyses. Las Vegas, Nevada. January 2003.

— 2003d. Annual Site Environmental Report - 2002, Nevada Test Site. DOE/NV/11718--842. Las Vegas, Nevada. October 2003. , 2002a. Evaluation of the Regulations and Issues Associated with the Final Closure of the Greater Confinement Disposal Boreholes. Las Vegas, Nevada. September 2002.

— 2002b. National Emissions Standards for Hazardous Air Pollutants, Calendar Year 2001. DOE/NV/11718--719. Las Vegas, Nevada. June 2002. , 2002c. Nevada Test Site 2001 Waste Management Monitoring Report, Area 3 and Area 5 Radioactive Waste Management Sites. DOE/NV/11718--718. Las Vegas, Nevada. June 2002.

—, 2001a. Performance Assessment for the Area 5 Radioactive Waste Management Site, Addendum 1. DOE/NV/11718-176-ADD1. Las Vegas, Nevada. November 2001. 
2001b. Composite Analysis for the Area 5 Radioactive Waste Management Site at the Nevada Test Site, Nye County, Nevada, Addendum 1. DOE/NV--594-ADD1. Las Vegas, Nevada. November 2001.

, 2001c. Composite Analysis for the Area 5 Radioactive Waste Management Site at the Nevada Test Site, Nye County, Nevada. DOE/NV--594. Las Vegas, Nevada.

September 2001.

, 2000a. Maintenance Plan for the Performance Assessments and Composite Analyses for the Area 3 and Area 5 Radioactive Waste Management Sites at the Nevada Test Site.

Las Vegas, Nevada.

- 2000b. Auditable Safety Analysis for the Area 3 and Area 5 Radioactive Waste Management Sites. ASA-4010-001, Rev. 0. Las Vegas, Nevada. August 2000.

—, 1999a. Bechtel Environmental Integrated Data Management System (BEIDMS). Las Vegas, Nevada.

—, 1999b. Calculation No. FD-DA-C-117. Las Vegas, Nevada. October 1999. , 1998a. Alternative Evaluation Study: Implementing Vadose Zone Monitoring at the Nevada Test Site-Issues Common to All Environmental Programs and Issues Unique to Radioactive Waste Management Sites, November 3-4, 1997. Las Vegas, Nevada. January 1998.

— $1998 \mathrm{~b}$. Revised Area 5 Radioactive Waste Management Site: Outline of a Comprehensive Groundwater Monitoring Program. Las Vegas, Nevada. February 1998.

—, 1997. 1996 Neutron Logging Data Report for the Radioactive Waste Management Sites at the Nevada Test Site. April 25, 1997.

Becker, B. D., W. A. Clayton, and B. M. Crowe, 2002. Waste Management at the Nevada Test Site Fiscal Year 2001, Current Status. U.S. Department of Energy, DOE/NV11718--714. Las Vegas, Nevada.

Becker, B. D., C. P. Gertz, W. A. Clayton, and B. M. Crowe, 1998. Low-Level Radioactive Waste (LLW) Management at the Nevada Test Site (NTS). U.S. Department of Energy, DOE/NV520. Las Vegas, Nevada.

Black, P., K. Black, L. Stahl, M. Hooten, T. Stockton, and D. Neptune, 2001. Assessing the Probability of Inadvertent Human Intrusion at the Nevada Test Site Radioactive Waste Management Sites. DOE/NV--593. March 2001.

Blout, D. O., D. P. Hammermeister, K. A. Zukosky, and K. D. Donnelson, 1995. Site Characterization Data from the Area 5 Science Boreholes, NTS, Nye County, Nevada. DOE/NV/11432-170. REECo. Las Vegas, Nevada. February 1995.

Campbell, K. W., 1980. Seismic Hazard Analysis for the Nevada Test Site Spent Reactor Fuel Test Site. UCRL-15620. Lawrence Livermore Laboratory, Livermore, California. 
Case, C., J. Davis, R. French, and S. Raker, 1984. Site Characterization in Connection With the Low-Level Defense Waste Management Site in Area 5 of the Nevada Test Site, Nye County, Nevada - Final Report. Desert Research Institute Publication No. 45034. Las Vegas, Nevada.

CFR. See Code of Federal Regulations.

Chapman, J. B., 1994. Classification of Groundwater at the Nevada Test Site. DOE/NV/10845-16. Desert Research Institute, Las Vegas, Nevada.

Chu, M.S.Y. and E. A. Bernard, 1991. Waste Inventory and Preliminary Source Term Model for the Greater Confinement Disposal Site at the Nevada Test Site. Prepared for the United States Department of Energy. Sandia Report: SAND91-0170, UC-902. Sandia National Laboratories, Albuquerque, New Mexico, and Livermore, California. First printing December 1991. Reprinted April 1998.

Clark, D. 2005. Personal Communication with D. Tobiason. September 15, 2005.

Cochran, J. R., B.M. Crowe, and A. Colarusso, 2001. "Results of the Performance Assessment for the Classified Transuranic Waste Disposed at the Nevada Test Site.” Paper presented by Sandia National Laboratories, Los Alamos National Laboratory, and U.S. Department of Energy Nevada Operation Office. Waste Management 2001 Conference, February 25-March 1, 2001, Tucson, Arizona.

Cochran, J. R., W. E. Beyler, D. A. Brosseau, L. Brush, T. J. Brown, B. Crowe, S. H. Conrad, P. A. Davis, T. Ehrhorn, T. Feeney, B. Fogleman, D. P. Gallegos, R. Haaker, D. Kalinina, L. L. Price, D. P. Thomas, and S. Wirth, 2001. Compliance Assessment for the Transuranic Wastes in the Greater Confinement Disposal Boreholes at the Nevada Test Site, Volume 2: Performance Assessment, Version 2.0. Sandia Report SAND2001-2977. Sandia National Laboratories, Albuquerque, New Mexico. September 2001.

Code of Federal Regulations, November 2001. Title 10 CFR 61.55, "Waste Classification,” 47 FR 27463 December 27, 1982, amended at 66 FR 55792, November, 2, 2001. , June 2001. Title 10 CFR 830, “Nuclear Safety Management,” 66 FR 1810, No. 7 June 10, 2001 , January 2001. Title 10 CFR 835, “Occupational Radiation Protection,” revised as of January 1, 2001. 58 FR 658485 December 14, 1993 as amended at 63 FR 59679 November 4, 1998.

, July 1999. Title 40 CFR 265, "Interim Status Standards for Owners and Operators of Hazardous Waste Treatment, Storage, and Disposal Facilities.” Revised July 1, 1999. , 1996a. Title 40 CFR 265, "Interim Status Standards for Owners and Operators of Hazardous Waste Treatment, Storage, and Disposal Facilities,” 1996. , 1996b. Title 40 CFR 191, "Environmental Radiation Protection Standards for Management and Disposal of Spent Nuclear Fuel, High-Level, and Transuranic Radioactive Wastes,” 1996.

, 1996c. Title 40 CFR 61, "National Emission Standards for Hazardous Air Pollutants." Revised July 1, 1996. 
, 1996d. Title 40 CFR 264, "Standards for Owners and Operators of Hazardous Waste Treatment, Storage, and Disposal Facilities,” 1996.

Cole, J. C., R. R. Wahl, and M. R. Hudson, 1989. "Structural Relations Within the Paleozoic Basement of Mine Mountain Block; Implications for Interpretation of Gravity Data in Yucca Flat, Nevada Test Site.” In: C. W. Olsen and J. A. Carter (eds.), Proceedings of the Fifth Symposium on Containment of Underground Nuclear Explosions. Lawrence Livermore National Laboratory Proceedings, CONF-850953, p. 431-456.

Crowe, B.M., 2004. Written Communication to D. Tobiason (Bechtel Nevada). September 2004.

Crowe, B. M., 1990. “Basaltic Episodes of the Yucca Mountain Region.” In: Proceedings, High-Level Radioactive Waste Management, International Conference, Las Vegas, Nevada. American Nuclear Society, La Grange, Illinois, p.65-73.

Crowe, B. M., P. Wallmann, and L. M. Bowker, 1998. "Probabilistic Modeling of Volcanism Data: Final Volcanic Hazard Studies for the Yucca Mountain Site.” In: Perry, F., B. M. Crowe, G. A. Valentine, J. Geissman, L. McFadden, S. Wells, M. Murrell, J. Poths, and L. Bowker, Volcanism Synthesis Report. Los Alamos National Laboratory, Los Alamos, New Mexico.

Crowe, B., W. Hansen, R. Waters, M. Sully, and D. Levitt, 1998. The Consequences of Disposal of Low-level Radioactive Waste from the Fernald Environmental Management Project: Report of the DOE/Nevada Independent Panel. LA-13453-MS. Los Alamos National Laboratory, Los Alamos, NM.

Crowe, B. M., M. T. Vaniman, and W. J., Carr, 1983. Status of Volcanic Hazard Studies for the Nevada Nuclear Waste Storage Investigation. LA-9325-MS. Los Alamos National Laboratory, Los Alamos, New Mexico.

Denton, R. C., M. R. Dolenc, and R. B. Hudson, September 2004. Unpublished Draft report. History of Radioactive Waste Disposal in Areas 3 and 5 of the Nevada Test Site 1953 to 2003. Bechtel Nevada, Las Vegas, Nevada. September 2004.

Desotell, L., September 2005. Personal communication to D. Wieland (Bechtel Nevada). September 21, 2005.

Dickman, P. T., 1998. Greater Confinement Disposal Test at the Nevada Test Site, Final Technology Report, Rev. 1. Prepared by SAIC for REECo, September 1998.

Dixon, J. M., 1999. An Evaluation of Unsaturated Flow Models in an Arid Climate. MS Thesis. University of Nevada, Las Vegas, Nevada.

Dockery-Ander, H .A., 1984. Rotation of Late Cenozoic Extensional Stress, Yucca Flat Region, Nevada Test Site. PhD Dissertation. Rice University, Houston, Texas.

DOE. See U.S. Department of Energy.

Dolenc, M., 2005. Personal Communication to D. Wieland (Bechtel Nevada). July 12, 2005 and July 21, 2005. 
Doorenbos, J., and W. O. Pruitt, 1977. Guidelines for Predicting Crop Water Requirements. FAO Irrigation and Drainage Paper No. 24, 2nd ed., FAO Rome, Italy.

Dreesen, D. R., and M. L. Marple, 1979. Uptake of Trace Elements and Radionuclides from Uranium Mill Tailings by Four-Wing Saltbush (Atriplex canescens) and Alkali Sacacton (Sporobolus airoides). LA-UR-79-3045. CONF-791140-1.

EPA (U.S. Environmental Protection Agency), 1994. "Guidance for the Data Quality Objectives Process.” EPA A/G-4. Quality Assurance Management Staff, Washington, D.C.

Estrella, R., 1994. Fate and Transport Processes Controlling the Migration of Hazardous and Radioactive Materials from the Area 5 Radioactive Waste Management Site (RWMS). Desert Research Institute Publication No. 45134, DOE/NV/19845--53, Las Vegas, NV.

FFACO (Federal Facilities Agreement and Consent Order), 1996. Prepared by the Nevada Division of Environmental Protection, the U.S. Department of Energy, and the U.S. Department of Defense.

Ford, B, 2005. Personal Communication with D. Wieland (Bechtel Nevada). July 14, 2005.

Foxx, T. S., G. D. Tierney, and J. M. Williams, 1984a. Rooting Depths of Plants on Low-Level Waste Sites. LA-10253-MS.

Foxx, T. S., G. D. Tierney, and J. M. Williams, 1984b. Rooting Depths of Plants as Related to Biological and Environmental Factors. LA-10254-MS.

French, R. H., and S. Curtis, 1999. The Precipitation Event of 23-24 February 1998: Analysis of a Design-Level Event. DOE/NV/11508-48. Desert Research Institute Publication 45170. September 1999.

Frizzell, J. A., Jr., and J. Shulters, 1990. Geologic Map of the Nevada Test Site, Southern Nevada. U.S. Geological Survey Miscellaneous Investigations Series Map I-2046, scale 1:100,000.

Gonzales J. L., S. L. Drellack, S. L., and M. T. Townsend, 1998. Descriptive Narrative for the Hydrogeologic Model at the Yucca Flat Corrective Area Unit. An interim report. Bechtel Nevada, Las Vegas, Nevada.

Gonzales J. L. and S. L. Drellack, 1999. "Addendum to the Descriptive Narrative for the Hydrogeologic Model of the Yucca Flat Corrective Area Unit: Northern Extension.” Bechtel Nevada, Las Vegas, Nevada.

Gustafson, D. L., S. E. Rawlinson, and J. J. Miller, 1993. Summary of Natural Resources that Potentially Influence Human Intrusion at the Area 5 RWMS, DOE/NTS, Nye County, Nevada. Raytheon Services Nevada. August 1993.

Hannon, R. M., and H. L. McKague, 1975. An Examination of the Geology and Seismology Associated with Area 410 at the Nevada Test Site. UCRL-51830. Lawrence Livermore National Laboratory, Livermore, California.

Hansen, D. J., 2005. Personal Communication to D. Wieland (Bechtel Nevada). September 20, 2005. 
Hansen, D. J., and W. K. Ostler, 2003. Rooting Characteristics of Vegetation Near Radioactive Waste Management Sites 3 and 5 at the Nevada Test Site. DOE/NV/11718--595. Las Vegas, NV. September 2003.

Hokett, S. L. and R. H. French, 1998. Evaluation of Recharge Potential at Crater U-5a. Desert Research Institute Publication 45160, DOE/NV/11508--32. Las Vegas, NV.

Hudson, D., 2005. Personal Communication to D. Wieland (Bechtel Nevada). September 6, 2005.

Hunter, R. B., and P. A. Medica. 1989. Status of the Flora and Fauna on the Nevada Test Site: Results of Continuing Basic Environmental Research, January through December 1987. DOE/NV/10630-2.

Istock, J. D., L. Barker, D. O. Blout, K. R. Johnejack, and D. P. Hammermeister, 1994. Spatial Variability in Hydrologic Properties of Alluvium at a Low-Level Nuclear Waste Disposal Site.

IT Corporation, 1999a. Underground Test Area Project Corrective Action Unit 98: Frenchman Flat Volume II - Groundwater Data Documentation Package, Rev. 0. DOE/NV/13052-044-V2. Las Vegas, Nevada. April 1999.

- 1999b. Underground Test Area Project Corrective Action Unit 98: Frenchman Flat Volume III - Groundwater Flow and Contaminant Transport Model Documentation Package, Rev. 0. DOE/NV/13502-V3. Las Vegas, Nevada. April 1999.

— 1998. Underground Test Area Subproject Corrective Action Unit 98: Frenchman Flat Data Analysis Task, Vol. 1 - Hydrostratigraphic Model Documentation Package, Rev. 0. ITLV/13052-044. Las Vegas, Nevada. August 1998.

Laczniak, R. J., J. C. Cole, D. A. Sawyer, and D. A. Trudeau, 1996. Summary of Hydrogeologic Controls on Ground-Water Flow at the Nevada Test Site, Nye County, Nevada. U.S. Geological Survey Water-Resources Investigations Report 96-4109.

Levitt, D. G., and V. Yucel, 2002a. "Infiltration Modeling to Support the Design of Closure Covers at the Radioactive Waste Management Sites at the Nevada Test Site” (Abstract). Bechtel Nevada. Las Vegas, Nevada.

Levitt, D. G., and V. Yucel, 2002b. Potential Groundwater Recharge and the Effects of Soil Heterogeneity on Flow at Two Radioactive Waste Management Sites at the Nevada Test Site. DOE/NV/11718--609. Bechtel Nevada. Las Vegas, Nevada.

Levitt, D. G., M. J. Sully, B. L. Dozier, and C. F. Lohrstorfer, 1999. “Determining the Performance of an Arid Zone Radioactive Waste Site Through Site Characterization, Modeling, and Monitoring.” In: Proceedings of the Waste Management 1999 Conference, Tucson, Arizona. DOE/NV/11718--307.

Levitt, D. G., B. L. Dozier, J. M. Dixon, and L. T. Desotell, 1998. “The Influence of Climate and Vegetation as Factors for Waste Cover Design.” In: Proceedings of the DOE Nevada Vadose Zone Monitoring Workshop, September 24-25, 1998, Las Vegas, Nevada. 
Levitt, D. G., M. J. Sully, and C. F. Lohrstorfer, 1997. Annual Data Report for the Water Balance Monitoring Program at the Area 5 Radioactive Waste Management Site. Bechtel Nevada. Las Vegas, Nevada. September 30, 1997.

Levitt, D. G., C. F. Lohrstorfer, M. J. Sully, and J. M. Ginanni, 1996. “An Arid Zone Lysimeter Facility for Performance Assessment and Closure Investigations at the Nevada Test Site." In: Proceedings of Waste Management 1996 Conference, Tucson, Arizona. DOE/NV/10833-34. Bechtel Nevada, Las Vegas, Nevada.

Lindstrom, F. T., D. E. Cawlfield, M. E. Donahue, D. E. Emer, and G. J. Shott, 1993. A Simulation of the Transport and Fate of Radon-222 Derived from Throrium-230 Low-Level Waste in the Near-Surface Zone of the Radioactive Waste Management Site in Area 5 of the Nevada Test Site. DOE/NV/10630-58. Reynolds Electrical and Engineering Co., Inc., Las Vegas, Nevada.

Magnuson, S. O., S. J. Maheras, H. D. Nguyen, A. S. Rood, J. I. Sipos, M. J. Case, M. A. McKenzie-Carter, and M. E. Donahue, 1992. Radiological Performance Assessment for the Area 5 Radioactive Waste Management Site at the Nevada Test Site, Revision 1. Idaho National Engineering Laboratory, Idaho Falls, Idaho.

Metcalf, L. A., 1983. A Preliminary Review and Summary of the Potential for Tectonic, Seismic, and Volcanic Activity at the Nevada Test Site Defense Waste Disposal Site. Desert Research Institute, Water Resources Center Publication 45029. DOE/NV/01162-7.

Miller, J. J. and D. L. Gustafson, 1994. A Multiple Method Approach to Flood Assessment at the Low-Level Radioactive Waste Management Site in Southern Nevada. Raytheon Services, Nevada.

NAC. See Nevada Administrative Code.

NNSA/NSO. See National Nuclear Security Administration Nevada Site Office.

National Nuclear Security Administration Nevada Site Office (NNSA/NSO), 2005a. Nevada Test Site Waste Acceptance Criteria. DOE/NV-325, Rev. 6. Las Vegas, Nevada. October 2005.

NNSA/NSO, 2005b. Well Completion Report for Well Cluster ER-5-3. DOE/NV/11718--1093. Las Vegas, Nevada.

Nevada Administrative Code (NAC) 444.743, "Final Cover or Closure; Postclosure.” September 2, 1992; amended November 8, 1993.

- NAC 444.6891, "Requirements for Design and Construction of System for Final Cover.” November 8, 1993.

NEC (Nevada Environmental Commission), 1987. "NAC 444.8632 - Compliance with Federal Regulations Adopted by Reference.” July 22, 1987 as amended.

NDEP. See Nevada Division of Environmental Protection.

Nevada Division of Environmental Protection (NDEP), 2000. "Permit for a Hazardous Waste Facility,” Permit No. NEV HW009. 
Obi, C. M., G. J. Shott, C. J. Muller, and L. E. Barker, 1996. Preliminary Estimates of Future Waste Subsidence, Hydrogeologic Impact, and Contaminant Concentrations for Area 3 RWMS Disposal Units at the NTS. Bechtel Nevada, Las Vegas, Nevada. October 1996.

O’Farrell, T. P., and L. A. Emery, 1976. Ecology of the Nevada Test Site: A Narrative Summary and Annotated Bibliography. NVO-167. National Technical Information Service Publication, Springfield, Virginia.

Orkild, P. P., 1983. “Geology of Nevada Test Site.” In: B. C. Hudson, E. M. Jones, C. E. Keller, and C. W. Smith (eds.), Proceedings of the Monterey Containment Symposium, Monterey, California, August 26-28, 1981. LA-9211-C, v.1, p. 323-338. Los Alamos National Laboratory Report.

Ostler W.K, D.C. Anderson, D. B. Hall, and D. J. Hansen. New Technologies to Reclaim Arid Lands Users Manual. DOE/NV/11718-731. Bechtel Nevada, Las Vegas, Nevada. October 2002.

Ostler, W. K., D. J. Hansen, D. C. Anderson, and D. B. Hall, 2000. Classification of Vegetation on the Nevada Test Site. DOE/NV/11718--477. Las Vegas, Nevada. December 2000.

NDEP (Nevada Division of Environmental Protection), 1995. "Permit for a Hazardous Waste Facility,” Permit No. NEV HW009.

Phelps, G. A., and Graham, S.E., 2002. Preliminary Gravity Inversion Model of Frenchman Flat Basin, Nevada Test Site, Nevada. U.S. Geological Survey Open File Report 02-363.

Phillips, F. M., J. L. Mattick, T. A. Duval, D. Elmore, and P. W. Kubick, 1988. Chlorine-36 and Tritium from Nuclear Weapons Fallout as Tracers for Long-Term Liquid and Vapor Movement in Desert Soils. Water Resources Research, v. 24, pp.877-891.

Prothro, L. August 8, 2002. Written communication to P. K. Ortego (Bechtel Nevada).

Raytheon Services Nevada, 1991. Unpublished draft report. Surficial Geology of the Area 5 Radioactive Waste Management Site. September 1991.

REECo. See Reynolds Electrical \& Engineering Co., Inc.

Reynolds Electrical \& Engineering Co., Inc. (REECo), 1993a. Hydrogeologic Data for Existing Excavations at the Area 5 RWMS, NTS, Nye County, Nevada. DOE/NV/11432-40. December 1993.

—, 1993b. Hydrogeologic Data for Science Trench Boreholes at the Area 5 RWMS, NTS, Nye County, Nevada. DE-AC08-94- NV 11432 UC 721. December 1993.

Rogers, A. M., D. M. Perkins, and F. A. McKeown, 1977. “A Preliminary Assessment of the Seismic Hazard of the Nevada Test Site Region.” Bulletin of the Seismology Society of America, Vol. 67, p. 1587-1606.

Romney, E. M., A. Wallace, and J. D. Childress, 1973. "Revegetation Problems Following Nuclear Testing Activities at the Nevada Test Site.” In: Nelson, ed., Radionuclides in Ecosystems, Proceedings of the Third National Symposium on Radioecology. CONF-710501, pp. 1,015-1,022. 
Rudolph, D., 2005. Personal Communication to D. Wieland. (Bechtel Nevada). November 22, 2005.

RSN. See Raytheon Services Nevada.

Schmeltzer, J. S., J. J. Miller, and D. L. Gustafson, 1993. Flood Assessment at the Area 5 Radioactive Waste Management Site and the Proposed Hazardous Waste Storage Unit, DOE, Nevada Test Site, Nye County, Nevada. Raytheon Services Nevada, Las Vegas, Nevada.

Sheppard, S. C., and W. G. Evenden, 1988. “Critical Compilation and Review of Plant/Soil Concentration Ratios for Uranium, Thorium, and Lead.” Journal of Environmental Radioactivity, 8:255-285.

Shott, G. J., 2005. Personal communication to D. Wieland (Bechtel Nevada). September 7, 2005 and November 16, 2005.

Shott, G. J., L. E. Barker, S. E. Rawlinson, M. J. Sully, and B. A. Moore, 1998. Performance Assessment of the Area 5 RWMS at the NTS, Nye County, Nevada, Revision 2.1. DOE/NV/11718--176. Bechtel Nevada, Las Vegas, Nevada. January 1998.

Shott, G. J., V. Yucel, M. J. Sully, L. E. Barker, S. E. Rawlinson, and B. A. Moore, 1997. Performance Assessment/Composite Analysis for the Area 3 RWMS at the NTS, Nye County, Nevada, Revision 2.0. DOE/NV--491. Bechtel Nevada, Las Vegas, Nevada. September 1997.

Shott, G. J., S. J. Sully, C. J. Muller, D. P. Hammermeister, J. M. Ginanni, 1995. Site Characterization and Performance Assessment for a Low-Level Radioactive Waste Management Site in the American Southwest. Reynolds Electrical \& Engineering Co., Inc. DOE/NV/11432--192. November 1995.

Snyder, K. E., R. D. Van Remortel, D. L. Gustafson, H. E. Huckins-Gang, J. J. Miller, S. E. Rawlinson, and S. M. Parsons, 1995. Surficial Geology and Landscape Development in Northern Frenchman Flat, Area 5 RWMS, DOE NTS. Interim Summary and Soil Data Report. Raytheon Services Nevada, Las Vegas, Nevada. September 1995.

Snyder K. E., D. L. Gustafson, J. J. Miller, S.E. Rawlinson, 1994. Geological Components of Site Characterization and Performance Assessment for a Radioactive Waste Management Facility at the Nevada Test Site. DOE/NV/10833-20.

Sorola, J., 2005. Personal Communication to D. Wieland (Bechtel Nevada). August 3, 2005.

Sully, M. J., 1992. Vadose Zone Air Permeability Tests in Pilot Well No. 1, Area 5.

Sully, M. J., D. E. Cawlfield, D.O. Bloat, L. E. Barker, B. L. Dozer, and D. P. Hammermeister, 1993. "Characterization of the Spatial Variability of Hydraulic Properties of an Arid Region Vadose Zone.” American Geophysical Union Supplement to EOS Abstract, 1993 Fall Meeting.

Sutter, G. W., II, R. J. Lemoore, and E. D. Smith, 1993. “Compacted Soil Barriers at Abandoned Landfill Sites are Likely to Fail in the Long Term." Journal of Environmental Quality, 22(2):217-226. 
Thompson, M., 1993. Burrowing Animals at the Nevada Test Site: A Literature Study. Unpublished supporting documentation for the Area 5 GCD Performance Assessment, prepared by Sandia National Laboratories for the U.S. Department of Energy under Contract DE-AC04-94AL85000.

Tierney, G. D., and T. S. Foxx, 1987. Root Lengths of Plant on Los Alamos National Laboratory Lands. LA-10865-MS.

Trauxe, J. 2005. Personal communication to D. Wieland (Bechtel Nevada), November 16, 2005.

Tyler, S. W., J. B. Chapman, S. H. Conrad, D. P. Hammermeister, D. O. Blout, J. J. Miller, M. J. Sully, and J. M Ginanni, 1996. "Soil-Water Flux in the Southern Great Basin, United States: Temporal and Spatial Variations over the Last 120,000 Years.” Water Resources Research 32(6):1481-1499.

U.S. Department of Energy, 2002. US DOE Standard DOE-STD-1153-2002, “A Graded Approach for Evaluating Radiation Doses to Aquatic and Terrestrial Biota." , 2000a. Disposal Authorization Statement for the Department of Energy/Nevada Operations Office Nevada Test Site Area 5 Radioactive Waste Management Site. Las Vegas, Nevada. December 5, 2000.

_ 2000b. United States Nuclear Tests, July 1945 through September 1992. DOE/NV-209-Rev.15. Las Vegas, Nevada. December 2000.

— 1999. DOE Order 435.1, "Radioactive Waste Management.” Washington, D.C. July 9, 1999.

— 1998. Consequences of Subsidence for the Area 3 and Area 5 RWMS, Nevada Test Site (Working Group Report). DOE/NV-502. Las Vegas, Nevada.

— 1993. DOE Order 5400.1, Chg. 1. "General Environmental Protection Program.” Washington, D.C. June 29, 1990.

— 1991. Environmental Regulatory Guide for Radiological Effluent Monitoring and Environmental Surveillance. DOE/EH-0173T. January 1991. , 1988. DOE Order 5820.2A, “Radioactive Waste Management.” Washington, D.C. September 26, 1988.

, 1999. DOE Order 414.1A, “Quality Assurance.” Washington, D.C. September 29, 1999.

Wallace, A., E. M. Romney, and R. B. Hunter, 1980. "The Challenge of a Desert: Revegetation of Disturbed Desert Lands.” In: Great Basin Naturalist Memoirs, No. 4. Brigham Young University.

Wallace, A., and E. M. Romney, 1972. Radioecology and Ecophysiology of Desert Plant at the Nevada Test Site. TID-25954. NTIS, Department of Commerce, Springfield, Virginia.

Walvoord, M.A., M.A. Plummer, F. M. Phillips, and A. V. Wolfsberg, 2002. "Deep Arid System Hydrodynamics, 1." Equilibrium states and response times in thick desert vadose zones. Water Resources Res. 38(12): 44-1-44-15. 
Walvoord, M. A., F. M. Phillips, S. W. Tyler, P. C. Hartsough, 2002. "Deep Arid System Hydrodynamics, 2.” Application to paleohydrologic reconstruction using vadose zone profiles from the northern Mojave Desert. Water Resources Res. 38 (12): 27-1-276-12.

Warren R., 2005. Personal communication to D. Hudson (Bechtel Nevada) transmitted to D. Wieland (Bechtel Nevada). September 6, 2005.

Webb R. H., M. B. Murov, T. C. Esque, D. E. Boyer, L. A. DeFalco, D. F. Haines, D. Oldershaw, S. J. Scoles, K. A. Thomas, J. B. Blainey, and P. A. Medica, 2003. Perennial Vegetation Data from Permanent Plots on the Nevada Test Site, Nye County, Nevada. U.S. Geological Survey Open File Report 03-336, Tucson, Arizona 2003.

Whicker, F. W., 1978. "Biological Interactions and Reclamation of Uranium Mill Tailings." Symposium on Uranium Mill Tailings Management, Fort Collins, Colorado. November 20-21, 1978.

Wills, C. A. and W. K. Ostler, December 2001. Ecology of the Nevada Test Site: An Annotated Bibliography, with Narrative Summary, Keyword Index, and Species List. DOE/NV/11718-594. December 2001.

Winkel, Von K., J. P. Angerer, D. B. Hall, M. W. Fariss, and K. R. Johnejack, 1995. Plant and Burrowing Animal Characteristics, Integrated Closure Program for the Area 3 and Area 5 Radioactive Waste Management Sites, Nevada Test Site. U.S. Department of Energy, Nevada Operations Office, Las Vegas, Nevada. March 1995.

Winograd, I. J., and W. Thordarson, 1975. Hydrogeologic and Hydrochemical Framework, South-Central Great Basin, Nevada-California, with Special Reference to the Nevada Test Site. U.S. Geological Survey Professional Paper 712-C.

Wirth, S., T. Brown, and W. Beyler, 1999. Native Plant Uptake Model for Radioactive Waste Disposal Areas at the Nevada Test Site. SAND98-1789. Sandia National Laboratories Report.

Wolfsberg, A. and P. Stauffer, 2003. Vadose Zone Fluid and Solute Flux: Advection and Diffusion at the Area 5 Radioactive Waste Management Site. LA-UR-03-4819. Los Alamos National Laboratory, Los Alamos, New Mexico.

Yucel, V. 2005. Personal Communication to D. Wieland (Bechtel Nevada). August 4, 2005. 
APPENDIX A

NTS WASTE DISPOSAL RECORD SUMMARIES

1961-2004 
This page intentionally left blank 
NTS WASTE DISPOSAL RECORDS - PAPER

\begin{tabular}{|c|c|c|c|c|c|}
\hline Location & Ship Cnt & First Disposal & Last Disposal & Ext Vol (ft $\left.{ }^{3}\right)$ & Curies \\
\hline \hline T01C & 72 & $10 / 10 / 1965$ & $5 / 19 / 1976$ & 17695.8 & 2093.55409 \\
\hline T01U & 391 & $1 / 7 / 1961$ & $4 / 1 / 1989$ & 29418.2 & 8.8899325 \\
\hline T02U & 73 & $7 / 5 / 1972$ & $5 / 5 / 1978$ & 35026.4 & 2.84048194 \\
\hline T03C & 158 & $8 / 26 / 1969$ & $12 / 10 / 1976$ & 25116.6 & 2006.87325 \\
\hline T04U & 573 & $2 / 25 / 1970$ & $9 / 21 / 1977$ & 47712.18 & 888.073779 \\
\hline T05C & 1 & $1 / 31 / 1974$ & $1 / 31 / 1974$ & 2000 & 0.0002 \\
\hline T06U & 845 & $7 / 1 / 1965$ & $5 / 25 / 1970$ & 166139.218 & 12620.2522 \\
\hline T07U & 111 & $5 / 16 / 1978$ & $9 / 22 / 1978$ & 90155 & 1.78273632 \\
\hline UNKN & 13 & $6 / 30 / 1970$ & $12 / 16 / 1976$ & 1346.05 & 0.9986112 \\
\hline TOTALS & 2237 & & & $\mathbf{4 1 4 6 0 9 . 4 4 8}$ & $\mathbf{1 7 6 2 3 . 2 6 5 2 8}$ \\
\hline
\end{tabular}

Source: Bechtel Nevada, Personnal Communication, R. Denton, September 15, 2005.

Summary of data from legible scanned historic NTS radioactive waste disposal records (paper records).

Paper records span from 1961 through 1978. 
NTS WASTE DISPOSAL RECORDS - RWMS

\begin{tabular}{|c|c|c|c|c|c|}
\hline Location & First Disposal & Last Disposal & Ext Vol (m3) & Ext Vol (ft3) & Curies \\
\hline P01U & 3/12/1979 & 4/24/1985 & 46612.04712 & 1646104.444 & 2214643.893 \\
\hline P02U & $12 / 18 / 1984$ & 11/19/1995 & 25115.15245 & 886941.6088 & 201013.6639 \\
\hline P03U & $3 / 25 / 1986$ & 8/29/1992 & 68129.68064 & 2405999.672 & 141692.9205 \\
\hline P04U & 6/14/1988 & 10/25/1995 & 43819.37887 & 1547481.365 & 35157.69981 \\
\hline P06U & $12 / 3 / 1994$ & 12/3/1995 & 507.455 & 17920.77333 & 38.95556174 \\
\hline T02C & 11/7/1988 & 9/28/1992 & 1268.083686 & 44782.37537 & 119.670152 \\
\hline T03U & 3/2/1992 & 9/10/1992 & 673.235168 & 23775.29996 & 2.0465447 \\
\hline T04C & $12 / 12 / 1985$ & 1/31/1992 & 349.85981 & 12355.29919 & 41.34241655 \\
\hline T04U & 3/31/1976 & 11/29/1977 & 62.976 & 2223.99744 & 670900.0609 \\
\hline T07U & & & 664.74 & 23475.2931 & 0.343301715 \\
\hline U5RWMS04C & 7/19/1985 & $1 / 14 / 1987$ & 56.271 & 1987.210365 & 16.8704 \\
\hline U5RWMS05U & 2/5/1986 & 4/8/1987 & 76.538 & 2702.93947 & 1947490.031 \\
\hline U5RWMS06U & $7 / 16 / 1986$ & $2 / 20 / 1987$ & 6.7677 & 239.0013255 & 6530.92 \\
\hline U5RWMS07C & 7/7/1989 & 7/7/1989 & 10.873728 & 384.0057043 & 1.885 \\
\hline U5RWMS10U & $12 / 11 / 1987$ & 10/27/1989 & 57.72827 & 2038.673855 & 602624.6209 \\
\hline TOTAL & & & 187410.7874 & 6618411.959 & 5820274.923 \\
\hline
\end{tabular}

Source: Bechtel Nevada, Personnal Communication, R. Denton, September 15, 2005.

Summary of radioactive waste disposal data from the Radioactive Waste Management System database which was developed and implemented in 1988. This database was replaced by the Low Level Waste Information System in 1992. The data period covered by the RWMS database overlaps with the paper records. 
NTS WASTE DISPOSAL RECORDS - LWIS

\begin{tabular}{|l|c|r|r|r|}
\hline Location & First Disposal & Last Disposal & Ext Vol (ft3) & Curies \\
\hline \hline P03U & $9 / 11 / 1996$ & $9 / 25 / 2003$ & 17633.5338 & 0.060459215 \\
\hline P04U & $10 / 1 / 1992$ & $6 / 8 / 1995$ & 935852.493 & 79846.8344 \\
\hline P05U & $5 / 15 / 1995$ & $5 / 25 / 2004$ & 2153116.14 & 2148720.19 \\
\hline P06U & $12 / 3 / 1994$ & $4 / 25 / 2002$ & 159009.407 & 248.517483 \\
\hline P06UA & $2 / 13 / 2003$ & $6 / 28 / 2004$ & 253621.959 & 108.313865 \\
\hline P07U & $9 / 15 / 1997$ & $2 / 10 / 2003$ & 180912.51 & 66.0598055 \\
\hline P08U & $5 / 21 / 2002$ & $7 / 1 / 2004$ & 592807.046 & 188285.59 \\
\hline P09U & $12 / 10 / 2003$ & $6 / 28 / 2004$ & 29972.5915 & 66.8851214 \\
\hline P10C & $6 / 24 / 2002$ & $7 / 1 / 2004$ & 818133.14 & 44930.794 \\
\hline P11U & $1 / 27 / 2004$ & $6 / 30 / 2004$ & 74876.592 & 13683.1928 \\
\hline T02C & $10 / 1 / 1992$ & $7 / 22 / 1993$ & 15196.4476 & 23.0380161 \\
\hline T04C & $6 / 23 / 1993$ & $8 / 3 / 1995$ & 51231.45 & 1615.91419 \\
\hline T07C & $5 / 14 / 2001$ & $4 / 23 / 2003$ & 663314.162 & 2544.34894 \\
\hline T09C & $8 / 3 / 1995$ & $10 / 31 / 2002$ & 43997.9722 & 71147.6239 \\
\hline Total & & & 5989675.444 & 2551287.363 \\
\hline
\end{tabular}

Source: Bechtel Nevada, Personnal Communication, R. Denton, September 15, 2005.

Summary of radioactive waste disposal records from the current database system, October 1, 1992 through December 2004. This includes an overlap of the Nevada Test Site Waste Acceptance Criteria format which was implemented in May 1997 and the Low-Level Waste Information System which was implemented October 1, 1992. 



\section{APPENDIX B \\ CLOSURE INVENTORY PROJECTIONS}


This page intentionally left blank 
Prepared by: G. Shott

Date:

9/7/2005

Program A5 Inventory.gsm

Vers.

v2.014

Realizations 500

All activities are decayed to 9/31/2028

All activities are the geometric mean

\begin{tabular}{|c|c|c|c|c|c|c|}
\hline Nuclide & $\begin{array}{l}\text { Pre-1988 Shallow Land } \\
\text { Burial Inventory } \\
\text { (Ci) }\end{array}$ & $\begin{array}{c}\text { Post } 1988 \text { Shallow } \\
\text { Land Burial Inventory } \\
\text { (Ci) } \dagger\end{array}$ & $\begin{array}{l}\text { Lower Cell of Pit } 6 \\
\text { Inventory } \\
\text { (Ci) }\end{array}$ & $\begin{array}{l}\text { Pit } 13 \text { Inventory } \\
\text { (Ci) } \dagger\end{array}$ & $\begin{array}{l}\text { Pre-1988 GCD } \\
\text { Inventory } \\
\text { (Ci) }\end{array}$ & $\begin{array}{l}\text { Post-1988 GCD } \\
\text { Inventory } \\
\text { (Ci) }\end{array}$ \\
\hline H3 & 8.14E+05 & $1.59 \mathrm{E}+06$ & $0.00 \mathrm{E}+00$ & $0.00 \mathrm{E}+00$ & $5.61 \mathrm{E}+05$ & $4.28 \mathrm{E}+03$ \\
\hline C14 & $6.67 \mathrm{E}+00$ & $3.63 E+00$ & $0.00 \mathrm{E}+00$ & $0.00 \mathrm{E}+00$ & $5.81 \mathrm{E}-07$ & $0.00 \mathrm{E}+00$ \\
\hline Al26 & $2.16 \mathrm{E}-04$ & $9.15 \mathrm{E}-07$ & $0.00 \mathrm{E}+00$ & $0.00 \mathrm{E}+00$ & 2.09E-11 & $0.00 \mathrm{E}+00$ \\
\hline $\mathrm{Cl} 36$ & $1.21 \mathrm{E}+00$ & $5.74 \mathrm{E}-03$ & $0.00 \mathrm{E}+00$ & $0.00 \mathrm{E}+00$ & $1.28 \mathrm{E}-07$ & $0.00 \mathrm{E}+00$ \\
\hline Ar39 & $5.53 E+00$ & $2.51 \mathrm{E}-02$ & $0.00 \mathrm{E}+00$ & $0.00 \mathrm{E}+00$ & 5.77E-07 & $0.00 \mathrm{E}+00$ \\
\hline K40 & 3.14E-01 & $2.40 \mathrm{E}-01$ & $0.00 \mathrm{E}+00$ & $0.00 \mathrm{E}+00$ & $3.44 \mathrm{E}-08$ & $0.00 \mathrm{E}+00$ \\
\hline Ca41 & $8.64 \mathrm{E}+00$ & 3.92E-02 & $0.00 \mathrm{E}+00$ & $0.00 \mathrm{E}+00$ & 8.83E-07 & $0.00 \mathrm{E}+00$ \\
\hline Ni59 & 2.30E-01 & $9.43 \mathrm{E}-03$ & $0.00 \mathrm{E}+00$ & $0.00 \mathrm{E}+00$ & $2.28 \mathrm{E}-08$ & $0.00 \mathrm{E}+00$ \\
\hline Ni63 & $1.73 E+01$ & $2.57 \mathrm{E}+00$ & $0.00 \mathrm{E}+00$ & $0.00 \mathrm{E}+00$ & $1.98 \mathrm{E}-06$ & $0.00 \mathrm{E}+00$ \\
\hline Co60 & 4.67E+01 & $1.06 \mathrm{E}+01$ & $0.00 \mathrm{E}+00$ & $0.00 \mathrm{E}+00$ & $2.94 \mathrm{E}+01$ & $0.00 \mathrm{E}+00$ \\
\hline Kr85 & $1.05 \mathrm{E}+01$ & $3.20 \mathrm{E}-02$ & $0.00 \mathrm{E}+00$ & $0.00 \mathrm{E}+00$ & $5.55 \mathrm{E}-07$ & $0.00 \mathrm{E}+00$ \\
\hline Sr90 & $4.65 \mathrm{E}+04$ & $8.49 E+02$ & 4.93E-04 & $0.00 \mathrm{E}+00$ & $2.03 E+05$ & $2.29 \mathrm{E}-03$ \\
\hline Zr93 & $2.95 \mathrm{E}-02$ & 1.43E-04 & $0.00 \mathrm{E}+00$ & $0.00 \mathrm{E}+00$ & $3.22 \mathrm{E}-09$ & $0.00 \mathrm{E}+00$ \\
\hline Nb93m & $2.84 \mathrm{E}+00$ & 2.36E-02 & $0.00 \mathrm{E}+00$ & $0.00 \mathrm{E}+00$ & 5.38E-07 & $0.00 \mathrm{E}+00$ \\
\hline Nb94 & $7.21 \mathrm{E}+00$ & 3.18E-02 & $0.00 \mathrm{E}+00$ & $0.00 \mathrm{E}+00$ & 7.47E-07 & $0.00 \mathrm{E}+00$ \\
\hline Tc99 & $2.80 \mathrm{E}+02$ & $4.58 \mathrm{E}+03$ & $2.53 \mathrm{E}-02$ & $0.00 \mathrm{E}+00$ & $2.56 \mathrm{E}-01$ & $1.26 \mathrm{E}-01$ \\
\hline Pd107 & $1.32 \mathrm{E}-03$ & 5.93E-06 & $0.00 \mathrm{E}+00$ & $0.00 \mathrm{E}+00$ & 1.45E-10 & $0.00 \mathrm{E}+00$ \\
\hline Cd113m & $2.34 \mathrm{E}+00$ & $2.26 \mathrm{E}-02$ & $0.00 \mathrm{E}+00$ & $0.00 \mathrm{E}+00$ & 5.04E-07 & $0.00 \mathrm{E}+00$ \\
\hline Sn121m & $6.48 \mathrm{E}+01$ & 3.45E-01 & $0.00 \mathrm{E}+00$ & $0.00 \mathrm{E}+00$ & 7.77E-06 & $0.00 \mathrm{E}+00$ \\
\hline Sn126 & $1.28 \mathrm{E}-02$ & 6.85E-05 & $0.00 \mathrm{E}+00$ & $0.00 \mathrm{E}+00$ & 1.40E-09 & $0.00 \mathrm{E}+00$ \\
\hline $\mathbf{I 1 2 9}$ & $9.41 \mathrm{E}-04$ & 4.06E-02 & $0.00 \mathrm{E}+00$ & $0.00 \mathrm{E}+00$ & $7.42 \mathrm{E}-11$ & $0.00 \mathrm{E}+00$ \\
\hline Ba133 & 4.49E-03 & 7.79E-02 & $0.00 \mathrm{E}+00$ & $0.00 \mathrm{E}+00$ & $0.00 \mathrm{E}+00$ & $0.00 \mathrm{E}+00$ \\
\hline Cs135 & 2.31E-02 & $1.08 \mathrm{E}-04$ & $0.00 \mathrm{E}+00$ & $0.00 \mathrm{E}+00$ & $2.52 \mathrm{E}-09$ & $0.00 \mathrm{E}+00$ \\
\hline Cs137 & $6.54 \mathrm{E}+04$ & $2.05 E+04$ & $0.00 \mathrm{E}+00$ & $0.00 \mathrm{E}+00$ & $9.02 \mathrm{E}+03$ & $0.00 \mathrm{E}+00$ \\
\hline Eu150 & $9.49 E+00$ & $5.01 \mathrm{E}-02$ & $0.00 \mathrm{E}+00$ & $0.00 \mathrm{E}+00$ & $1.08 \mathrm{E}-06$ & $0.00 \mathrm{E}+00$ \\
\hline Eu152 & $6.15 E+01$ & $2.82 \mathrm{E}-01$ & $0.00 E+00$ & $0.00 \mathrm{E}+00$ & 3.93E-06 & $0.00 \mathrm{E}+00$ \\
\hline Eu154 & $6.74 \mathrm{E}+00$ & 8.00E-02 & $0.00 \mathrm{E}+00$ & $0.00 \mathrm{E}+00$ & 8.11E-07 & $0.00 \mathrm{E}+00$ \\
\hline Sm151 & $2.69 \mathrm{E}+01$ & $1.38 \mathrm{E}-01$ & $0.00 \mathrm{E}+00$ & $0.00 \mathrm{E}+00$ & 3.31E-06 & $0.00 \mathrm{E}+00$ \\
\hline Ho166m & $2.76 \mathrm{E}-01$ & $1.22 \mathrm{E}-03$ & $0.00 \mathrm{E}+00$ & $0.00 \mathrm{E}+00$ & $2.87 \mathrm{E}-08$ & $0.00 \mathrm{E}+00$ \\
\hline Bi207 & 1.23E-05 & 1.82E-06 & $0.00 \mathrm{E}+00$ & $0.00 \mathrm{E}+00$ & $0.00 \mathrm{E}+00$ & $0.00 \mathrm{E}+00$ \\
\hline $\mathrm{Pb} 210$ & $2.61 \mathrm{E}+01$ & $1.97 \mathrm{E}+00$ & $1.78 \mathrm{E}-01$ & $1.03 E+00$ & $7.48 \mathrm{E}+01$ & $9.15 \mathrm{E}-07$ \\
\hline Ra226 & $3.39 \mathrm{E}+01$ & $2.44 \mathrm{E}+00$ & 5.06E-01 & $2.19 \mathrm{E}+00$ & $1.00 \mathrm{E}+02$ & 3.01E-06 \\
\hline Ra226 & $3.39 E+01$ & $2.44 \mathrm{E}+00$ & 5.06E-01 & $2.19 \mathrm{E}+00$ & $1.00 \mathrm{E}+02$ & 3.01E-06 \\
\hline Ra228 & $1.23 \mathrm{E}+00$ & $2.04 \mathrm{E}+01$ & $1.57 \mathrm{E}+02$ & $1.38 \mathrm{E}+02$ & 2.01E-02 & $6.24 \mathrm{E}-19$ \\
\hline Ac227 & $2.85 \mathrm{E}-01$ & $1.01 \mathrm{E}-01$ & $6.46 \mathrm{E}-05$ & $0.00 \mathrm{E}+00$ & $2.85 \mathrm{E}+00$ & 1.32E-05 \\
\hline Th228 & $1.63 \mathrm{E}+00$ & $2.32 \mathrm{E}+01$ & $1.56 \mathrm{E}+02$ & $1.34 \mathrm{E}+02$ & $2.00 \mathrm{E}-02$ & $5.27 \mathrm{E}-19$ \\
\hline Th229 & 4.14E-03 & $2.23 \mathrm{E}-02$ & $1.31 \mathrm{E}-01$ & $0.00 \mathrm{E}+00$ & 2.19E-09 & 1.16E-09 \\
\hline Th230 & 9.99E-01 & $1.18 \mathrm{E}+01$ & $3.93 E+01$ & $3.54 \mathrm{E}+01$ & 2.33E-03 & $3.62 \mathrm{E}-04$ \\
\hline Th232 & $1.24 \mathrm{E}+00$ & $2.16 \mathrm{E}+01$ & $1.60 \mathrm{E}+02$ & $1.47 \mathrm{E}+02$ & 2.03E-02 & $9.44 \mathrm{E}-19$ \\
\hline Pa231 & 1.76E-01 & $1.32 \mathrm{E}-01$ & 1.73E-04 & $0.00 \mathrm{E}+00$ & 2.00E-04 & $3.10 \mathrm{E}-05$ \\
\hline U232 & 2.96E-01 & $2.27 \mathrm{E}+00$ & $0.00 \mathrm{E}+00$ & $0.00 \mathrm{E}+00$ & 3.50E-08 & $0.00 \mathrm{E}+00$ \\
\hline U233 & 8.86E-01 & $9.52 \mathrm{E}+00$ & $4.90 \mathrm{E}+01$ & $0.00 \mathrm{E}+00$ & 1.11E-06 & 6.37E-07 \\
\hline U234 & $1.94 \mathrm{E}+03$ & $2.66 \mathrm{E}+03$ & $4.80 \mathrm{E}+00$ & $0.00 \mathrm{E}+00$ & $5.87 \mathrm{E}+00$ & $1.02 \mathrm{E}+00$ \\
\hline U235 & $7.88 \mathrm{E}+01$ & $1.17 \mathrm{E}+02$ & $2.56 \mathrm{E}-01$ & $0.00 \mathrm{E}+00$ & $2.19 \mathrm{E}-01$ & $3.81 \mathrm{E}-02$ \\
\hline U236 & $2.41 \mathrm{E}+01$ & $7.83 \mathrm{E}+01$ & 4.90E-03 & $0.00 \mathrm{E}+00$ & 1.73E-02 & $9.92 \mathrm{E}-10$ \\
\hline U238 & $2.20 \mathrm{E}+03$ & $4.86 \mathrm{E}+03$ & $5.96 \mathrm{E}+00$ & $0.00 \mathrm{E}+00$ & 9.97E-01 & $1.90 \mathrm{E}+00$ \\
\hline Np237 & $5.39 \mathrm{E}+00$ & $1.51 \mathrm{E}+00$ & $2.25 \mathrm{E}-05$ & $0.00 \mathrm{E}+00$ & $6.73 \mathrm{E}-03$ & $3.80 \mathrm{E}-03$ \\
\hline Pu238 & $1.60 \mathrm{E}+02$ & $1.00 \mathrm{E}+02$ & 3.83E-01 & $0.00 \mathrm{E}+00$ & $4.70 \mathrm{E}+00$ & 7.38E-05 \\
\hline Pu239 & $3.22 E+02$ & $1.38 \mathrm{E}+02$ & $9.20 \mathrm{E}-05$ & $0.00 \mathrm{E}+00$ & $2.60 \mathrm{E}+02$ & 4.14E-03 \\
\hline Pu240 & $7.51 \mathrm{E}+01$ & $3.17 \mathrm{E}+01$ & $0.00 \mathrm{E}+00$ & $0.00 \mathrm{E}+00$ & $5.85 \mathrm{E}+01$ & $8.68 \mathrm{E}-04$ \\
\hline Pu241 & $9.01 E+01$ & $8.72 E+01$ & 2.91E-01 & $0.00 \mathrm{E}+00$ & $6.34 \mathrm{E}+01$ & $1.26 \mathrm{E}-03$ \\
\hline Pu242 & $1.62 \mathrm{E}-02$ & $1.73 \mathrm{E}+01$ & $0.00 \mathrm{E}+00$ & $0.00 \mathrm{E}+00$ & $5.63 \mathrm{E}-03$ & $0.00 \mathrm{E}+00$ \\
\hline Pu244 & 1.39E-01 & $2.19 \mathrm{E}-08$ & $0.00 \mathrm{E}+00$ & $0.00 \mathrm{E}+00$ & $0.00 \mathrm{E}+00$ & $0.00 \mathrm{E}+00$ \\
\hline Am241 & $1.02 \mathrm{E}+02$ & $3.13 \mathrm{E}+01$ & $2.71 \mathrm{E}-02$ & $0.00 \mathrm{E}+00$ & $1.09 \mathrm{E}+02$ & 7.70E-04 \\
\hline Am243 & 1.14E-02 & $1.08 \mathrm{E}-02$ & $0.00 \mathrm{E}+00$ & $0.00 \mathrm{E}+00$ & $2.93 \mathrm{E}-10$ & $0.00 \mathrm{E}+00$ \\
\hline Cm243 & $1.28 \mathrm{E}-01$ & $9.46 \mathrm{E}-04$ & $0.00 \mathrm{E}+00$ & $0.00 \mathrm{E}+00$ & $0.00 \mathrm{E}+00$ & $0.00 \mathrm{E}+00$ \\
\hline $\mathrm{Cm} 244$ & $1.95 \mathrm{E}+00$ & $6.74 \mathrm{E}+00$ & $0.00 \mathrm{E}+00$ & $0.00 \mathrm{E}+00$ & $6.63 E-08$ & $0.00 \mathrm{E}+00$ \\
\hline Cm245 & 3.34E-06 & $8.38 \mathrm{E}-03$ & $0.00 \mathrm{E}+00$ & $0.00 \mathrm{E}+00$ & $0.00 \mathrm{E}+00$ & $0.00 \mathrm{E}+00$ \\
\hline Cm246 & 1.93E-06 & 1.32E-03 & $0.00 \mathrm{E}+00$ & $0.00 \mathrm{E}+00$ & $0.00 \mathrm{E}+00$ & $0.00 \mathrm{E}+00$ \\
\hline Cm248 & 1.66E-06 & $6.84 \mathrm{E}-08$ & $0.00 \mathrm{E}+00$ & $0.00 \mathrm{E}+00$ & $0.00 \mathrm{E}+00$ & $0.00 \mathrm{E}+00$ \\
\hline Cf250 & 6.33E-06 & $0.00 \mathrm{E}+00$ & $0.00 \mathrm{E}+00$ & $0.00 \mathrm{E}+00$ & $0.00 \mathrm{E}+00$ & $0.00 \mathrm{E}+00$ \\
\hline
\end{tabular}



APPENDIX C

AREA 5 SAMPLING AND MONITORING LOCATIONS 
This page intentionally left blank 
AREA 5 MONITORING LOCATIONS

\begin{tabular}{|c|c|c|c|c|c|c|c|c|c|c|c|c|}
\hline STATION & STATION ID & TYPE & STATUS & GRID_PLANE & NORTHING & EASTING & UNITS & LONGITUDEL L & LATITUDE & $\begin{array}{c}\text { GROUND } \\
\text { ELEVATION }\end{array}$ & $\begin{array}{l}\text { REFERENCE } \\
\text { ELEVATION }\end{array}$ & UNITS \\
\hline 10848 & $U-5 A$ & BH EMP & EXPENDED & NV ST PLN-NAD27 & 753500 & 709999 & FT & -115.950092 & 36.817962 & 3086 & 3086 & $\mathrm{FT}$ \\
\hline 10849 & U-5A PS \#1A & BH POST SHOT & ACTIVE & NV ST PLN-NAD27 & 753266 & 709885 & FT & -115.95049 & 36.817322 & 3083 & 3083 & FT \\
\hline 10861 & UE-5C WATER WELL & BH EXPL & ACTIVE & NV ST PLN-NAD27 & 760133 & 700997 & FT & -115.980683 & 36.836362 & 3216 & 3216 & FT \\
\hline 10862 & $U-5 D$ & BH EMP & ACTIVE & NV ST PLN-NAD27 & 756600 & 707901 & FT & -115.957181 & 36.82652 & 3120 & 3120 & FT \\
\hline 10863 & $U-5 E$ & BH EMP & EXPENDED & NV ST PLN-NAD27 & 755419 & 704831 & FT & -115.967699 & 36.823338 & 3137 & 3137 & FT \\
\hline 10864 & U-5E PS \#1A & BH POST SHOT & ACTIVE & NV ST PLN-NAD27 & 755823 & 704831 & FT & -115.967689 & 36.824448 & 3136 & 3136 & $F T$ \\
\hline 10867 & UE-5F & BH EXPL & ACTIVE & NV ST PLN-NAD27 & 772499 & 710901 & FT & -115.946521 & 36.870128 & 3301 & 3301 & $F T$ \\
\hline 10868 & U-5G & BH EMP & ACTIVE & NV ST PLN-NAD27 & 752542 & 709097 & FT & -115.953198 & 36.815349 & & & FT \\
\hline 10870 & UE-5I & BH EXPL & PLUGGED & NV ST PLN-NAD27 & 775216 & 709282 & FT & -115.951986 & 36.877624 & 3427 & 3427 & FT \\
\hline 10871 & U-5I FOIL RECOVERY HOLE & BH TEST & ACTIVE & NV ST PLN-NAD27 & 774447 & 709415 & FT & -115.951551 & 36.875509 & 3395 & 3395 & $\mathrm{FT}$ \\
\hline 10872 & U-5I CABLE HOLE \#1 & $\mathrm{BH}$ CABLE & PLUGGED & NV ST PLN-NAD27 & 774755 & 709458 & FT & -115.951396 & 36.876354 & 3404 & 3404 & FT \\
\hline 10874 & U-5I PS \#1A & BH POST SHOT & ACTIVE & NV ST PLN-NAD27 & 774924 & 709798 & FT & -115.95023 & 36.876811 & 3404 & 3404 & FT \\
\hline 10877 & U-5K & BH EMP & EXPENDED & NV ST PLN-NAD27 & 773094 & 715146 & FT & -115.931994 & 36.871673 & 3349 & 3349 & FT \\
\hline
\end{tabular}

Data extracted September 2005 from the Bechtel Integrated Data Management System (BEIDMS) 
AREA 5 MONITORING LOCATIONS

\begin{tabular}{|c|c|c|c|c|c|c|c|c|c|c|c|c|}
\hline STATION & STATION ID & TYPE & STATUS & GRID_PLANE & NORTHING & EASTING & UNITS & LONGITUDE & LATITUDE & $\begin{array}{c}\text { GROUND } \\
\text { ELEVATION }\end{array}$ & $\begin{array}{l}\text { REFERENCE } \\
\text { ELEVATION }\end{array}$ & UNITS \\
\hline 10878 & UE-5K & BH EXPL & PLUGGED & NV ST PLN-NAD27 & 773094 & 715247 & FT & -115.931649 & 36.871671 & 3349 & 3349 & $\mathrm{FT}$ \\
\hline 10879 & $U-5 \mathrm{~L}$ & BH EMP & PLUGGED & NV ST PLN-NAD27 & 773094 & 713147 & FT & -115.938828 & 36.871715 & & & FT \\
\hline 10881 & UE-5M & BH EXPL & ACTIVE & NV ST PLN-NAD27 & 732500 & 682000 & FT & -116.046211 & 36.760818 & & & FT \\
\hline 10883 & RNM \#1 & BH RNM & ACTIVE & NV ST PLN-NAD27 & 755823 & 704831 & FT & -115.967689 & 36.824448 & 3136 & 3136 & $F T$ \\
\hline 10853 & WATER WELL 5A & WL POT & ACTIVE & NV ST PLN-NAD27 & 738361 & 707514 & FT & -115.958964 & 36.77643 & 3093 & 3093 & FT \\
\hline 10854 & U-5B & BH EMP & EXPENDED & NV ST PLN-NAD27 & 753500 & 707999 & FT & -115.956925 & 36.818003 & 3095 & 3095 & $F T$ \\
\hline 10855 & U-5B PS \#1A & BH POST SHOT & ACTIVE & NV ST PLN-NAD27 & 753698 & 707802 & FT & -115.957593 & 36.818551 & 3095 & 3095 & FT \\
\hline 10858 & WATER WELL 5B & WL POT & ACTIVE & NV ST PLN-NAD27 & 747359 & 704263 & FT & -115.969841 & 36.801211 & 3092 & 3092 & FT \\
\hline 10859 & U-5C & BH EMP & ACTIVE & NV ST PLN-NAD27 & 754800 & 709000 & FT & -115.953472 & 36.821553 & 3100 & 3100 & $F T$ \\
\hline 10860 & WATER WELL 5C & WL POT & ACTIVE & NV ST PLN-NAD27 & 742860 & 705888 & FT & -115.964403 & 36.788821 & 3081 & 3081 & FT \\
\hline 10893 & U-5 RWMS \#6U & BH DISPOSAL & ACTIVE & NV ST PLN-NAD27 & & & FT & & & & & FT \\
\hline 10894 & U-5 RWMS \#7C & BH DISPOSAL & ACTIVE & NV ST PLN-NAD27 & 767625 & 708217 & FT & -115.955821 & 36.856796 & & & FT \\
\hline 10895 & U-5 RWMS \#8C & BH DISPOSAL & ACTIVE & NV ST PLN-NAD27 & 767601 & 708208 & FT & -115.955852 & 36.85673 & & & FT \\
\hline
\end{tabular}

Data extracted September 2005 from the Bechtel Integrated Data Management System (BEIDMS) 
AREA 5 MONITORING LOCATIONS

\begin{tabular}{|c|c|c|c|c|c|c|c|c|c|c|c|c|}
\hline STATION & STATION ID & TYPE & STATUS & GRID_PLANE & NORTHING & EASTING & UNITS & LONGITUDE & LATITUDE & $\begin{array}{c}\text { GROUND } \\
\text { ELEVATION } \\
\end{array}$ & $\begin{array}{l}\text { REFERENCE } \\
\text { ELEVATION } \\
\end{array}$ & UNITS \\
\hline 10896 & U-5 RWMS \#9U & BH DISPOSAL & ACTIVE & NV ST PLN-NAD27 & 767407 & 708087 & FT & -115.956271 & 36.8562 & & & FT \\
\hline 10897 & U-5 RWMS \#10U & BH DISPOSAL & ACTIVE & NV ST PLN-NAD27 & 767427 & 708103 & FT & -115.956215 & 36.856254 & & & FT \\
\hline 10898 & U-5 RWMS \#11U & BH DISPOSAL & ACTIVE & NV ST PLN-NAD27 & & & FT & & & & & FT \\
\hline 10899 & U-5 RWMS \#12U & BH DISPOSAL & ACTIVE & NV ST PLN-NAD27 & & & FT & & & & & FT \\
\hline 10900 & RCRA \#1 & BH EM & ACTIVE & NV ST PLN-NAD27 & & & FT & & & & & FT \\
\hline 10901 & USGS HTH \#3 & $\mathrm{BH} \mathrm{HTH}$ & ACTIVE & NV ST PLN-NAD27 & 750189 & 736937 & FT & -115.858162 & 36.808279 & 3477 & 3477 & FT \\
\hline 10884 & RNM \#2 & BH RNM & ACTIVE & NV ST PLN-NAD27 & 755264 & 705088 & FT & -115.966825 & 36.822907 & 3132 & 3132 & FT \\
\hline 10869 & U-5I MINING & SHAFT & EXPENDED & NV ST PLN-NAD27 & 774568 & 709412 & FT & -115.951559 & 36.875841 & 3395 & 3395 & FT \\
\hline 10905 & TEST HOLE \#1 & BH TEST & PLUGGED & NV ST PLN-NAD27 & 766241 & 709337 & FT & -115.952028 & 36.852971 & & & FT \\
\hline 10906 & TEST HOLE \#1A & BH TEST & ACTIVE & NV ST PLN-NAD27 & & & FT & & & & & FT \\
\hline 10907 & TEST HOLE \#2 & BH TEST & ACTIVE & NV ST PLN-NAD27 & 766771 & 709435 & $\mathrm{FT}$ & -115.95168 & 36.854425 & & & FT \\
\hline 10908 & U-5 SEISMIC \#1 & BH SEISMIC & PLUGGED & NV ST PLN-NAD27 & 749607 & 668099 & FT & -116.093317 & 36.808045 & 3869 & 3869 & FT \\
\hline 10909 & U-5 SEISMIC \#2 & BH SEISMIC & PLUGGED & NV ST PLN-NAD27 & 749623 & 668122 & FT & -116.093238 & 36.808089 & 3868 & 3868 & FT \\
\hline 10910 & UE5PW-1 & BH EM & ACTIVE & NV ST PLN-NAD27 & 765702 & 709832 & FT & -115.95035 & 36.851481 & 3177.99 & 3180.35 & FT \\
\hline 10911 & UE5PW-2 & BH EM & ACTIVE & NV ST PLN-NAD27 & 770395 & 709894 & FT & -115.950018 & 36.86437 & 3246.23 & 3248.42 & $F T$ \\
\hline
\end{tabular}

Data extracted September 2005 from the Bechtel Integrated Data Management System (BEIDMS) 
AREA 5 MONITORING LOCATIONS

\begin{tabular}{|c|c|c|c|c|c|c|c|c|c|c|c|c|}
\hline STATION & STATION ID & TYPE & STATUS & GRID_PLANE & NORTHING & EASTING & UNITS & LONGITUDE & LATITUDE & $\begin{array}{c}\text { GROUND } \\
\text { ELEVATION }\end{array}$ & $\begin{array}{l}\text { REFERENCE } \\
\text { ELEVATION }\end{array}$ & UNITS \\
\hline 10912 & UE5PW-3 & $\mathrm{BH} \mathrm{EM}$ & ACTIVE & NV ST PLN-NAD27 & 771291 & 703460 & FT & -115.971989 & 36.866961 & 3295.51 & 3297.97 & FT \\
\hline 10902 & TEST HOLE \#4 & BH TEST & PLUGGED & NV ST PLN-NAD27 & 763910 & 689551 & FT & -116.019708 & 36.846956 & 3405 & 3405 & FT \\
\hline 10885 & RNM \#2S & BH RNM & ACTIVE & NV ST PLN-NAD27 & 755200 & 704809 & FT & -115.96778 & 36.822737 & 3133 & 3133 & FT \\
\hline 10886 & U-5 RNM \#3 & BH RNM & PLUGGED & NV ST PLN-NAD27 & & & FT & & & & & FT \\
\hline 10887 & U-5 RNM \#4 & BH RNM & ACTIVE & NV ST PLN-NAD27 & & & FT & & & & & FT \\
\hline 10888 & U-5 RNM \#5 & BH RNM & ACTIVE & NV ST PLN-NAD27 & 754015 & 706383 & FT & -115.962432 & 36.81945 & 3111 & 3111 & FT \\
\hline 10889 & U-5 RWMS CONTROL \#1 & BH DISPOSAL & ACTIVE & NV ST PLN-NAD27 & & & FT & & & & & FT \\
\hline 10890 & U-5 RWMS \#4C & BH DISPOSAL & ACTIVE & NV ST PLN-NAD27 & & & FT & & & & & FT \\
\hline 10891 & U-5 RWMS \#5 & BH DISPOSAL & ACTIVE & NV ST PLN-NAD27 & & & FT & & & & & FT \\
\hline 10892 & U-5 RWMS \#5U & BH DISPOSAL & ACTIVE & NV ST PLN-NAD27 & & & FT & & & & & FT \\
\hline 10882 & UE-5N & BH EXPL & ACTIVE & NV ST PLN-NAD27 & 754460 & 706415 & FT & -115.962312 & 36.820672 & 3112 & 3112 & FT \\
\hline 10903 & TEST HOLE \#5 & BH TEST & PLUGGED & NV ST PLN-NAD27 & 734799 & 690124 & FT & -116.018424 & 36.766985 & 3233 & 3233 & FT \\
\hline 1614 & 3.3 MILES SE OF AGGREGATE PIT & ETLD & ACTIVE & $\begin{array}{l}\text { UTM Z11 meters } \\
\text { WGS84 }\end{array}$ & 4066275 & 595702 & FT & 115.9281 & 36.737378 & 3569 & & FT \\
\hline 1615 & CANE SPRING & NS & & NV ST PLN-NAD27 & & & FT & & & & & FT \\
\hline 1616 & DOD & AMS & ACTIVE & NV ST PLN-NAD27 & 772090 & 709862 & FT & $\begin{array}{r}115.950089 \\
011\end{array}$ & $\begin{array}{r}36.869022 \\
275 \\
\end{array}$ & 3301 & & FT \\
\hline 1617 & RWMS EAST 1000 & ETLD & INACTIVE & NV ST PLN-NAD27 & & & FT & & & & & FT \\
\hline
\end{tabular}

Data extracted September 2005 from the Bechtel Integrated Data Management System (BEIDMS) 
AREA 5 MONITORING LOCATIONS

\begin{tabular}{|c|c|c|c|c|c|c|c|c|c|c|c|c|}
\hline STATION & STATION ID & TYPE & STATUS & GRID_PLANE & NORTHING & EASTING & UNITS & LONGITUDE & LATITUDE & $\begin{array}{c}\text { GROUND } \\
\text { ELEVATION }\end{array}$ & $\begin{array}{l}\text { REFERENCE } \\
\text { ELEVATION } \\
\end{array}$ & UNITS \\
\hline 1618 & RWMS EAST 1500 & ETLD & INACTIVE & NV ST PLN-NAD27 & & & FT & & & & & FT \\
\hline 1619 & RWMS EAST 0500 & ETLD & INACTIVE & NV ST PLN-NAD27 & & & FT & & & & & FT \\
\hline 1620 & RWMS EAST GATE & ETLD & ACTIVE & \begin{tabular}{|l|} 
UTM Z11 meters \\
WGS84
\end{tabular} & 4078991 & 593276 & FT & 115.95371 & 36.85223 & 3174 & & FT \\
\hline 1621 & RWMS MSM-1 EAST & ETLD & INACTIVE & NV ST PLN-NAD27 & & & FT & & & & & FT \\
\hline 1622 & RWMS MSM-1 NORTH-NORTHEAST & ETLD & INACTIVE & NV ST PLN-NAD27 & & & FT & & & & & FT \\
\hline 1623 & $\begin{array}{l}\text { RWMS MSM-1 NORTH- } \\
\text { NORTHWEST }\end{array}$ & ETLD & INACTIVE & NV ST PLN-NAD27 & & & FT & & & & & FT \\
\hline 1624 & RWMS MSM-1 NORTHEAST & ETLD & INACTIVE & NV ST PLN-NAD27 & & & FT & & & & & FT \\
\hline 1625 & RWMS MSM-1 NORTHWEST & ETLD & INACTIVE & NV ST PLN-NAD27 & & & FT & & & & & FT \\
\hline 1626 & RWMS MSM-1 SOUTH-SOUTHEAST & ETLD & INACTIVE & NV ST PLN-NAD27 & & & FT & & & & & FT \\
\hline 1627 & $\begin{array}{l}\text { RWMS MSM-1 SOUTH- } \\
\text { SOUTHWEST }\end{array}$ & ETLD & INACTIVE & NV ST PLN-NAD27 & & & FT & & & & & FT \\
\hline 1628 & RWMS MSM-1 SOUTHEAST & ETLD & INACTIVE & NV ST PLN-NAD27 & & & FT & & & & & FT \\
\hline 1629 & RWMS MSM-1 SOUTHWEST & ETLD & INACTIVE & NV ST PLN-NAD27 & & & FT & & & & & FT \\
\hline 1630 & RWMS MSM-1 WEST & ETLD & INACTIVE & NV ST PLN-NAD27 & & & FT & & & & & FT \\
\hline 1631 & RWMS MSM-2 EAST & ETLD & INACTIVE & NV ST PLN-NAD27 & & & FT & & & & & FT \\
\hline 1632 & RWMS MSM-2 NORTH & ETLD & INACTIVE & NV ST PLN-NAD27 & & & FT & & & & & FT \\
\hline 1633 & RWMS MSM-2 NORTHEAST & ETLD & INACTIVE & NV ST PLN-NAD27 & & & FT & & & & & FT \\
\hline 1634 & RWMS MSM-2 NORTHWEST & ETLD & INACTIVE & NV ST PLN-NAD27 & & & FT & & & & & FT \\
\hline 1635 & RWMS MSM-2 SOUTH & ETLD & INACTIVE & NV ST PLN-NAD27 & & & FT & & & & & FT \\
\hline 1636 & RWMS MSM-2 SOUTHEAST & ETLD & INACTIVE & NV ST PLN-NAD27 & & & FT & & & & & FT \\
\hline 1637 & RWMS MSM-2 SOUTHWEST & ETLD & INACTIVE & NV ST PLN-NAD27 & & & FT & & & & & FT \\
\hline
\end{tabular}

Data extracted September 2005 from the Bechtel Integrated Data Management System (BEIDMS) 
AREA 5 MONITORING LOCATIONS

\begin{tabular}{|c|c|c|c|c|c|c|c|c|c|c|c|c|}
\hline STATION & STATION ID & TYPE & STATUS & GRID_PLANE & NORTHING & EASTING & UNITS & LONGITUDE & LATITUDE & $\begin{array}{c}\text { GROUND } \\
\text { ELEVATION } \\
\end{array}$ & $\begin{array}{c}\text { REFERENCE } \\
\text { ELEVATION } \\
\end{array}$ & UNITS \\
\hline 1638 & RWMS MSM-2 WEST & ETLD & INACTIVE & NV ST PLN-NAD27 & & & FT & & & & & FT \\
\hline 1642 & RWMS 5 NORTH & AMS & INACTIVE & NV ST PLN-NAD27 & & & FT & & & & & FT \\
\hline 1643 & RWMS 6 NORTHWEST & AMS & INACTIVE & NV ST PLN-NAD27 & & & FT & & & & & FT \\
\hline 1647 & RWMS NORTH 1000 & ETLD & INACTIVE & NV ST PLN-NAD27 & & & FT & & & & & FT \\
\hline 1648 & RWMS NORTH 1500 & ETLD & INACTIVE & NV ST PLN-NAD27 & & & FT & & & & & FT \\
\hline 1649 & RWMS NORTH 0500 & ETLD & INACTIVE & NV ST PLN-NAD27 & & & FT & & & & & FT \\
\hline 1650 & RWMS NORTHEAST CORNER & ETLD & ACTIVE & $\begin{array}{l}\text { UTM Z11 meters } \\
\text { WGS84 }\end{array}$ & 4079605 & 593461 & FT & 115.95156 & 36.85775 & 3205 & & FT \\
\hline 1651 & RWMS NORTHWEST CORNER & ETLD & ACTIVE & $\begin{array}{l}\text { UTM Z11 meters } \\
\text { WGS84 }\end{array}$ & 4079459 & 592804 & FT & 115.95895 & 36.8565 & 3194 & & FT \\
\hline 1652 & RWMS OFFICE & ETLD & INACTIVE & NV ST PLN-NAD27 & & & FT & & & & & FT \\
\hline 1653 & RWMS PIT 5 & ETLD & INACTIVE & NV ST PLN-NAD27 & & & FT & & & & & FT \\
\hline 1654 & RWMS PIT 5 EAST & ETLD & INACTIVE & NV ST PLN-NAD27 & & & FT & & & & & FT \\
\hline 1655 & RWMS PIT 5 WEST & ETLD & INACTIVE & NV ST PLN-NAD27 & & & FT & & & & & FT \\
\hline 1656 & RWMS SEWAGE POND & SL & & NV ST PLN-NAD27 & & & FT & & & & & FT \\
\hline 1657 & RWMS SOUTH 0500 & ETLD & INACTIVE & NV ST PLN-NAD27 & & & FT & & & & & FT \\
\hline 1658 & RWMS SOUTH GATE & ETLD & ACTIVE & $\begin{array}{l}\text { UTM Z11 meters } \\
\text { WGS84 }\end{array}$ & 4079007 & 593214 & FT & 115.9544 & 36.852378 & 3174 & & FT \\
\hline 1659 & RWMS SOUTHWEST CORNER & ETLD & ACTIVE & $\begin{array}{l}\text { UTM Z11 meters } \\
\text { WGS84 }\end{array}$ & 4078997 & 592805 & FT & 115.95899 & 36.85233 & 3168 & & FT \\
\hline 1660 & RWMS TP BUILDING N & ETLD & INACTIVE & NV ST PLN-NAD27 & & & FT & & & & & FT \\
\hline 1661 & RWMS TP BUILDING S & ETLD & INACTIVE & NV ST PLN-NAD27 & & & FT & & & & & FT \\
\hline 1662 & RWMS TRU BUILDING NORTH & AMS & INACTIVE & NV ST PLN-NAD27 & & & FT & -115.953925 & $\begin{array}{r}36.852708 \\
333\end{array}$ & 3210 & & FT \\
\hline
\end{tabular}

Data extracted September 2005 from the Bechtel Integrated Data Management System (BEIDMS) 
AREA 5 MONITORING LOCATIONS

\begin{tabular}{|c|c|c|c|c|c|c|c|c|c|c|c|c|}
\hline STATION & STATION ID & TYPE & STATUS & GRID_PLANE & NORTHING & EASTING & UNITS & LONGITUDE & LATITUDE & $\begin{array}{c}\text { GROUND } \\
\text { ELEVATION }\end{array}$ & $\begin{array}{l}\text { REFERENCE } \\
\text { ELEVATION }\end{array}$ & UNITS \\
\hline 1663 & RWMS TRU BUILDING SOUTH & AMS & INACTIVE & NV ST PLN-NAD27 & & & FT & & & & & FT \\
\hline 1664 & RWMS TRU PAD NORTH & AMS & INACTIVE & NV ST PLN-NAD27 & & & FT & & & & & FT \\
\hline 1665 & RWMS TRU PAD NORTHEAST & AMS & INACTIVE & NV ST PLN-NAD27 & & & FT & & & & & FT \\
\hline 1666 & RWMS TRU PAD NORTHWEST & AMS & INACTIVE & NV ST PLN-NAD27 & & & FT & & & & & FT \\
\hline 1667 & RWMS TRU PAD SOUTH & AMS & INACTIVE & NV ST PLN-NAD27 & & & FT & & & & & FT \\
\hline 1668 & RWMS TRU PAD SOUTHEAST & AMS & INACTIVE & NV ST PLN-NAD27 & & & FT & & & & & FT \\
\hline 1669 & RWMS TRU PAD SOUTHWEST & AMS & INACTIVE & NV ST PLN-NAD27 & & & FT & & & & & FT \\
\hline 1670 & RWMS WEST 1000 & ETLD & INACTIVE & NV ST PLN-NAD27 & & & FT & & & & & FT \\
\hline 1671 & RWMS WEST 1500 & ETLD & INACTIVE & NV ST PLN-NAD27 & & & FT & & & & & FT \\
\hline 1672 & RWMS WEST 0500 & ETLD & INACTIVE & NV ST PLN-NAD27 & & & FT & & & & & FT \\
\hline 1673 & UE-5C WATER WELL RESERVOIR & OR & & NV ST PLN-NAD27 & & & FT & & & & & FT \\
\hline 1674 & WEF EAST & ETLD & ACTIVE & $\begin{array}{l}\text { UTM Z11 meters } \\
\text { WGS84 }\end{array}$ & 4078853 & 593439 & FT & 115.9519 & 36.85097 & 3195 & & FT \\
\hline 1675 & WEF NORTH & AMS & INACTIVE & NV ST PLN-NAD27 & & & FT & & & & & FT \\
\hline 1676 & WEF SOUTH & AMS & INACTIVE & NV ST PLN-NAD27 & & & FT & & & & & FT \\
\hline 1677 & WEF WEST & AMS & INACTIVE & NV ST PLN-NAD27 & & & FT & & & & & FT \\
\hline 1678 & WATER WELL 5B RESERVOIR & OR & & NV ST PLN-NAD27 & & & FT & & & & & FT \\
\hline 13592 & BOUNDARY STATION 360 & ETLD & INACTIVE & NV ST PLN-NAD27 & & & FT & & & & & FT \\
\hline 13593 & GATE 200 & AMS & INACTIVE & NV ST PLN-NAD27 & & & FT & & & & & FT \\
\hline 13594 & RWMS 1 OFFICE & AMS & INACTIVE & NV ST PLN-NAD27 & & & FT & & & & & FT \\
\hline 13595 & RWMS 2 SOUTHEAST & AMS & INACTIVE & NV ST PLN-NAD27 & & & FT & & & & & FT \\
\hline
\end{tabular}

Data extracted September 2005 from the Bechtel Integrated Data Management System (BEIDMS) 
AREA 5 MONITORING LOCATIONS

\begin{tabular}{|c|c|c|c|c|c|c|c|c|c|c|c|c|}
\hline STATION & STATION ID & TYPE & STATUS & GRID_PLANE & NORTHING & EASTING & UNITS & LONGITUDE & LATITUDE & $\begin{array}{c}\text { GROUND } \\
\text { ELEVATION }\end{array}$ & $\begin{array}{l}\text { REFERENCE } \\
\text { ELEVATION }\end{array}$ & UNITS \\
\hline 13596 & RWMS 3 EAST & AMS & INACTIVE & NV ST PLN-NAD27 & & & FT & & & & & FT \\
\hline 13597 & RWMS 4 NORTHEAST & AMS & INACTIVE & NV ST PLN-NAD27 & 767998 & 709401 & FT & $\begin{array}{r}115.951772 \\
069\end{array}$ & $\begin{array}{r}36.857737 \\
634\end{array}$ & 3303 & & FT \\
\hline 13598 & RWMS 5 NORTHWEST & AMS & INACTIVE & NV ST PLN-NAD27 & & & FT & & & & & FT \\
\hline 13599 & RWMS 6 NORTH & AMS & INACTIVE & NV ST PLN-NAD27 & & & FT & & & & & FT \\
\hline 13600 & RWMS 7 WEST & AMS & INACTIVE & NV ST PLN-NAD27 & & & FT & $\begin{array}{r}115.958611 \\
667\end{array}$ & 36.855195 & 3347 & & FT \\
\hline 13601 & RWMS 8 SOUTHWEST & AMS & INACTIVE & NV ST PLN-NAD27 & & & FT & & & & & FT \\
\hline 13602 & RWMS 9 SOUTH & AMS & INACTIVE & NV ST PLN-NAD27 & & & FT & -115.57355 & 36.511383 & 3259 & & FT \\
\hline 13603 & RWMS MSM-1 NORTH & ETLD & INACTIVE & NV ST PLN-NAD27 & & & FT & & & & & FT \\
\hline 13604 & RWMS PIT 3 & AMS & INACTIVE & NV ST PLN-NAD27 & & & FT & & & & & FT \\
\hline 13605 & RWMS PIT 3 NORTH & ETLD & INACTIVE & NV ST PLN-NAD27 & & & FT & & & & & FT \\
\hline 13606 & RWMS PIT 3 SOUTH & ETLD & INACTIVE & NV ST PLN-NAD27 & & & FT & & & & & FT \\
\hline 13607 & RWMS PIT 4 & AMS & INACTIVE & NV ST PLN-NAD27 & & & FT & & & & & FT \\
\hline 13608 & RWMS PIT 4 EAST & ETLD & INACTIVE & NV ST PLN-NAD27 & & & FT & & & & & FT \\
\hline 13609 & RWMS PIT 4 NORTH & ETLD & INACTIVE & NV ST PLN-NAD27 & & & FT & & & & & FT \\
\hline 13610 & RWMS PIT 4 SOUTH & ETLD & INACTIVE & NV ST PLN-NAD27 & & & FT & & & & & FT \\
\hline 13611 & RWMS PIT 4 WEST & ETLD & INACTIVE & NV ST PLN-NAD27 & & & FT & & & & & FT \\
\hline 151729 & WEF NORTHEAST & AMS & INACTIVE & NV ST PLN-NAD27 & & & FT & $\begin{array}{r}115.951561 \\
667\end{array}$ & $\begin{array}{r}36.852063 \\
333\end{array}$ & 3240 & & FT \\
\hline
\end{tabular}

Data extracted September 2005 from the Bechtel Integrated Data Management System (BEIDMS) 
AREA 5 MONITORING LOCATIONS

\begin{tabular}{|c|c|c|c|c|c|c|c|c|c|c|c|c|}
\hline STATION & STATION ID & TYPE & STATUS & GRID_PLANE & NORTHING & EASTING & UNITS & LONGITUDE & LATITUDE & $\begin{array}{c}\text { GROUND } \\
\text { ELEVATION }\end{array}$ & $\begin{array}{l}\text { REFERENCE } \\
\text { ELEVATION }\end{array}$ & UNITS \\
\hline 151730 & WEF SOUTHWEST & AMS & INACTIVE & NV ST PLN-NAD27 & & & FT & $\begin{array}{r}115.953196 \\
667\end{array}$ & $\begin{array}{r}36.850948 \\
333 \\
\end{array}$ & 3229 & & FT \\
\hline 151957 & UE5PW-1 MET TOWER & MET & ACTIVE & NV ST PLN-NAD27 & 766070 & 709999 & FT & $\begin{array}{r}115.949770 \\
278\end{array}$ & $\begin{array}{r}36.852488 \\
609 \\
\end{array}$ & 970.7 & & METERS \\
\hline 151958 & L1 MET TOWER & MET & ACTIVE & NV ST PLN-NAD27 & 765836 & 706083 & FT & $\begin{array}{r}115.963160 \\
213\end{array}$ & $\begin{array}{r}36.851925 \\
752 \\
\end{array}$ & 972.9 & & METERS \\
\hline 152081 & UE5PW-2 PPT & PPT & ACTIVE & NV ST PLN-NAD27 & 770396 & 709894 & FT & $\begin{array}{r}115.950018 \\
178 \\
\end{array}$ & $\begin{array}{r}36.864372 \\
917 \\
\end{array}$ & & 989.6 & METERS \\
\hline 152225 & WEIGHING LYSIMETER SOUTH & PPT & ACTIVE & NV ST PLN-NAD27 & 765964 & 705930 & FT & $\begin{array}{r}115.963679 \\
91 \\
\end{array}$ & $\begin{array}{r}36.852280 \\
418 \\
\end{array}$ & & 970 & METERS \\
\hline 152226 & WEIGHING LYSIMETER NORTH & PPT & ACTIVE & NV ST PLN-NAD27 & 765964 & 705930 & FT & $\begin{array}{r}115.963679 \\
91\end{array}$ & $\begin{array}{r}36.852280 \\
418 \\
\end{array}$ & & 970 & METERS \\
\hline 152321 & WELL 5B & AMS & INACTIVE & & & & & -115.582067 & 36.48065 & 3200 & & FT \\
\hline 152322 & RWMS GCD TRAILER & AMS & INACTIVE & & & & & & & & & \\
\hline 152323 & RWMS BLDG 5-6 ROOM 4 & AMS & INACTIVE & NV ST PLN-NAD27 & & & FT & & & & & \\
\hline 153047 & P03U-3 & ACCESS TUBE & ACTIVE & NV ST PLN-NAD27 & 767911 & 709286 & FT & $\begin{array}{r}115.952160 \\
075 \\
\end{array}$ & $\begin{array}{r}36.857559 \\
91 \\
\end{array}$ & & & FT \\
\hline 153048 & P03U-4 & ACCESS TUBE & ACTIVE & NV ST PLN-NAD27 & 767967 & 709258 & FT & $\begin{array}{r}115.952254 \\
348 \\
\end{array}$ & $\begin{array}{r}36.857714 \\
299 \\
\end{array}$ & & & FT \\
\hline 153049 & P03U-5 & ACCESS TUBE & ACTIVE & NV ST PLN-NAD27 & 767938 & 709258 & FT & $\begin{array}{r}115.952255 \\
089 \\
\end{array}$ & $\begin{array}{r}36.857634 \\
645 \\
\end{array}$ & & & FT \\
\hline 153050 & P03U-6 & ACCESS TUBE & ACTIVE & NV ST PLN-NAD27 & 767910 & 709258 & FT & $\begin{array}{r}115.952255 \\
805 \\
\end{array}$ & $\begin{array}{r}36.857557 \\
738 \\
\end{array}$ & & & FT \\
\hline 153051 & P03U-7 & ACCESS TUBE & ACTIVE & NV ST PLN-NAD27 & 767966 & 709230 & FT & $\begin{array}{r}115.952350 \\
077\end{array}$ & $\begin{array}{r}36.857712 \\
127\end{array}$ & & & FT \\
\hline
\end{tabular}

Data extracted September 2005 from the Bechtel Integrated Data Management System (BEIDMS) 
AREA 5 MONITORING LOCATIONS

\begin{tabular}{|c|c|c|c|c|c|c|c|c|c|c|c|c|}
\hline STATION & STATION ID & TYPE & STATUS & GRID_PLANE & NORTHING & EASTING & UNITS & LONGITUDE & LATITUDE & $\begin{array}{c}\text { GROUND } \\
\text { ELEVATION }\end{array}$ & $\begin{array}{l}\text { REFERENCE } \\
\text { ELEVATION }\end{array}$ & UNITS \\
\hline 153052 & P03U-8 & ACCESS TUBE & ACTIVE & NV ST PLN-NAD27 & 767938 & 709230 & $F T$ & $\begin{array}{r}115.952350 \\
793\end{array}$ & $\begin{array}{r}36.857635 \\
22 \\
\end{array}$ & & & FT \\
\hline 153054 & P03U-10 & ACCESS TUBE & ACTIVE & NV ST PLN-NAD27 & 767855 & 709287 & FT & $\begin{array}{r}115.952158 \\
09\end{array}$ & $\begin{array}{r}36.857406 \\
075\end{array}$ & & & FT \\
\hline 153055 & P03U-11 & ACCESS TUBE & ACTIVE & NV ST PLN-NAD27 & 767827 & 709287 & FT & $\begin{array}{r}115.952158 \\
806\end{array}$ & $\begin{array}{r}36.857329 \\
168\end{array}$ & & & FT \\
\hline 153056 & P03U-12 & ACCESS TUBE & ACTIVE & NV ST PLN-NAD27 & 767882 & 709258 & FT & $\begin{array}{r}115.952256 \\
521\end{array}$ & $\begin{array}{r}36.857480 \\
831\end{array}$ & & & FT \\
\hline 153058 & P03U-14 & ACCESS TUBE & ACTIVE & NV ST PLN-NAD27 & 767826 & 709258 & FT & $\begin{array}{r}115.952257 \\
953\end{array}$ & $\begin{array}{r}36.857327 \\
016\end{array}$ & & & FT \\
\hline 153059 & P03U-15 & ACCESS TUBE & ACTIVE & NV ST PLN-NAD27 & 767910 & 709230 & FT & $\begin{array}{r}115.952351 \\
509\end{array}$ & $\begin{array}{r}36.857558 \\
312 \\
\end{array}$ & & & FT \\
\hline 153060 & P03U-16 & ACCESS TUBE & ACTIVE & NV ST PLN-NAD27 & 767882 & 709230 & $F T$ & $\begin{array}{r}115.952352 \\
225\end{array}$ & $\begin{array}{r}36.857481 \\
405 \\
\end{array}$ & & & FT \\
\hline 153062 & P03U-18 & ACCESS TUBE & ACTIVE & NV ST PLN-NAD27 & 767826 & 709230 & $F T$ & $\begin{array}{r}115.952353 \\
657 \\
\end{array}$ & $\begin{array}{r}36.857327 \\
591 \\
\end{array}$ & & & FT \\
\hline 153063 & P03U-19 & ACCESS TUBE & ACTIVE & NV ST PLN-NAD27 & 767798 & 709287 & FT & $\begin{array}{r}115.952159 \\
547\end{array}$ & $\begin{array}{r}36.857249 \\
514 \\
\end{array}$ & & & FT \\
\hline 153064 & P03U-20 & ACCESS TUBE & ACTIVE & NV ST PLN-NAD27 & 767798 & 709259 & $F T$ & $\begin{array}{r}115.952255 \\
251\end{array}$ & $\begin{array}{r}36.857250 \\
089 \\
\end{array}$ & & & FT \\
\hline 153065 & P03U-21 & ACCESS TUBE & ACTIVE & NV ST PLN-NAD27 & 767798 & 709230 & $F T$ & $\begin{array}{r}115.952354 \\
373\end{array}$ & $\begin{array}{r}36.857250 \\
684 \\
\end{array}$ & & & FT \\
\hline 153068 & P03U-24 & ACCESS TUBE & ACTIVE & NV ST PLN-NAD27 & 767770 & 709230 & $F T$ & $\begin{array}{r}115.952355 \\
089\end{array}$ & $\begin{array}{r}36.857173 \\
777 \\
\end{array}$ & & & FT \\
\hline 153069 & P03U-50 & ACCESS TUBE & ACTIVE & NV ST PLN-NAD27 & & & FT & & & & & FT \\
\hline
\end{tabular}

Data extracted September 2005 from the Bechtel Integrated Data Management System (BEIDMS) 
AREA 5 MONITORING LOCATIONS

\begin{tabular}{|c|c|c|c|c|c|c|c|c|c|c|c|c|}
\hline STATION & STATION ID & TYPE & STATUS & GRID_PLANE & NORTHING & EASTING & UNITS & LONGITUDE & LATITUDE & $\begin{array}{c}\text { GROUND } \\
\text { ELEVATION }\end{array}$ & $\begin{array}{l}\text { REFERENCE } \\
\text { ELEVATION }\end{array}$ & UNITS \\
\hline 153072 & P03U-3A & ACCESS TUBE & ACTIVE & NV ST PLN-NAD27 & 767752.93 & $\begin{array}{r}709336.2 \\
2 \\
\end{array}$ & FT & $\begin{array}{r}115.951992 \\
467 \\
\end{array}$ & $\begin{array}{r}36.857124 \\
711 \\
\end{array}$ & & 3210.01 & FT \\
\hline 153073 & P03U-4A & ACCESS TUBE & ACTIVE & NV ST PLN-NAD27 & 767605.09 & $\begin{array}{r}709340.2 \\
2 \\
\end{array}$ & FT & $\begin{array}{r}115.951982 \\
577 \\
\end{array}$ & $\begin{array}{r}36.856718 \\
559 \\
\end{array}$ & & 3205.86 & FT \\
\hline 153074 & P01U-1 & ACCESS TUBE & ACTIVE & NV ST PLN-NAD27 & $\begin{array}{r}767168.107 \\
680876 \\
\end{array}$ & $\begin{array}{r}708549.0 \\
72733045 \\
\end{array}$ & FT & $\begin{array}{r}115.954697 \\
83 \\
\end{array}$ & $\begin{array}{r}36.855534 \\
515 \\
\end{array}$ & & 3195.24 & FT \\
\hline 153075 & P01U-2 & ACCESS TUBE & ACTIVE & NV ST PLN-NAD27 & $\begin{array}{r}767158.371 \\
194891 \\
\end{array}$ & $\begin{array}{r}708568.9 \\
91253666 \\
\end{array}$ & $\mathrm{FT}$ & $\begin{array}{r}115.954629 \\
998 \\
\end{array}$ & $\begin{array}{r}36.855507 \\
364 \\
\end{array}$ & & 3195.26 & FT \\
\hline 153076 & P01U-3 & ACCESS TUBE & ACTIVE & NV ST PLN-NAD27 & $\begin{array}{r}767100.214 \\
406686 \\
\end{array}$ & \begin{tabular}{|r|}
708538.1 \\
48533198 \\
\end{tabular} & FT & $\begin{array}{r}115.954736 \\
898\end{array}$ & $\begin{array}{r}36.855348 \\
256 \\
\end{array}$ & & 3193.79 & FT \\
\hline 153077 & P01U-4 & ACCESS TUBE & ACTIVE & NV ST PLN-NAD27 & $\begin{array}{r}767034.218 \\
055542 \\
\end{array}$ & $\begin{array}{r}708446.0 \\
75903406 \\
\end{array}$ & FT & $\begin{array}{r}115.955053 \\
274\end{array}$ & $\begin{array}{r}36.855168 \\
867 \\
\end{array}$ & & 3195.07 & FT \\
\hline 153078 & P01U-5 & ACCESS TUBE & ACTIVE & NV ST PLN-NAD27 & $\begin{array}{r}767035.197 \\
790819 \\
\end{array}$ & $\begin{array}{r}708509.2 \\
77968377 \\
\end{array}$ & FT & $\begin{array}{r}115.954837 \\
231 \\
\end{array}$ & $\begin{array}{r}36.855170 \\
266 \\
\end{array}$ & & 3193.52 & FT \\
\hline 153080 & P02U-1 & ACCESS TUBE & ACTIVE & NV ST PLN-NAD27 & $\begin{array}{r}767245.720 \\
83031 \\
\end{array}$ & $\begin{array}{r}708232.3 \\
87693849 \\
\end{array}$ & FT & $\begin{array}{r}115.955778 \\
258 \\
\end{array}$ & $\begin{array}{r}36.855754 \\
164 \\
\end{array}$ & & 3198.58 & FT \\
\hline 153082 & P02U-3 & ACCESS TUBE & ACTIVE & NV ST PLN-NAD27 & $\begin{array}{r}767202.798 \\
208333 \\
\end{array}$ & \begin{tabular}{|r|}
708281.5 \\
01005355 \\
\end{tabular} & FT & $\begin{array}{r}115.955611 \\
485 \\
\end{array}$ & $\begin{array}{r}36.855635 \\
266 \\
\end{array}$ & & 3196.9 & FT \\
\hline 153083 & P02U-4 & ACCESS TUBE & ACTIVE & NV ST PLN-NAD27 & $\begin{array}{r}767045.026 \\
332834 \\
\end{array}$ & $\begin{array}{r}708160.5 \\
21978159 \\
\end{array}$ & FT & $\begin{array}{r}115.956028 \\
995 \\
\end{array}$ & $\begin{array}{r}36.855204 \\
386 \\
\end{array}$ & & 3195.18 & FT \\
\hline 153084 & P02U-5 & ACCESS TUBE & ACTIVE & NV ST PLN-NAD27 & $\begin{array}{r}767022.463 \\
530358 \\
\end{array}$ & \begin{tabular}{|r|}
708219.4 \\
15739088 \\
\end{tabular} & FT & $\begin{array}{r}115.955828 \\
275 \\
\end{array}$ & $\begin{array}{r}36.855141 \\
211 \\
\end{array}$ & & 3194.8 & FT \\
\hline 153085 & P02U-6 & ACCESS TUBE & ACTIVE & NV ST PLN-NAD27 & $\begin{array}{r}766815.070 \\
262009 \\
\end{array}$ & $\begin{array}{r}708079.1 \\
49390356 \\
\end{array}$ & FT & $\begin{array}{r}115.956312 \\
965 \\
\end{array}$ & $\begin{array}{r}36.854574 \\
429 \\
\end{array}$ & & 3192.42 & FT \\
\hline 153088 & P04U-1 & ACCESS TUBE & ACTIVE & NV ST PLN-NAD27 & $\begin{array}{r}767696.339 \\
57121 \\
\end{array}$ & $\begin{array}{r}707681.6 \\
31267991 \\
\end{array}$ & FT & $\begin{array}{r}115.957649 \\
268\end{array}$ & $\begin{array}{r}36.857003 \\
103 \\
\end{array}$ & & 3198.47 & FT \\
\hline
\end{tabular}


AREA 5 MONITORING LOCATIONS

\begin{tabular}{|c|c|c|c|c|c|c|c|c|c|c|c|c|}
\hline STATION & STATION ID & TYPE & STATUS & GRID_PLANE & NORTHING & EASTING & UNITS & LONGITUDE & LATITUDE & $\begin{array}{c}\text { GROUND } \\
\text { ELEVATION }\end{array}$ & $\begin{array}{l}\text { REFERENCE } \\
\text { ELEVATION }\end{array}$ & UNITS \\
\hline 153089 & P04U-2 & ACCESS TUBE & ACTIVE & NV ST PLN-NAD27 & \begin{tabular}{|r|}
767694.588 \\
580887
\end{tabular} & $\begin{array}{r}707730.1 \\
31482791 \\
\end{array}$ & FT & $\begin{array}{r}115.957483 \\
54\end{array}$ & $\begin{array}{r}36.856997 \\
306\end{array}$ & & 3198.15 & $F T$ \\
\hline 153090 & P04U-3 & ACCESS TUBE & ACTIVE & NV ST PLN-NAD27 & \begin{tabular}{|r|}
767693.593 \\
682384 \\
\end{tabular} & \begin{tabular}{|r|}
707794.9 \\
73091737 \\
\end{tabular} & FT & $\begin{array}{r}115.957261 \\
937\end{array}$ & $\begin{array}{r}36.856993 \\
252 \\
\end{array}$ & & 3198.18 & FT \\
\hline 153091 & P04U-4 & ACCESS TUBE & ACTIVE & NV ST PLN-NAD27 & \begin{tabular}{|r|}
767556.451 \\
119449 \\
\end{tabular} & $\begin{array}{r}707694.1 \\
21870923\end{array}$ & FT & $\begin{array}{r}115.957610 \\
126\end{array}$ & $\begin{array}{r}36.856618 \\
619\end{array}$ & & 3196.79 & $\mathrm{FT}$ \\
\hline 153092 & P04U-5 & ACCESS TUBE & ACTIVE & NV ST PLN-NAD27 & \begin{tabular}{|r|}
767555.979 \\
697105 \\
\end{tabular} & $\begin{array}{r}707734.9 \\
94051431\end{array}$ & FT & $\begin{array}{r}115.957470 \\
438\end{array}$ & $\begin{array}{r}36.856616 \\
491\end{array}$ & & 3196.73 & FT \\
\hline 153093 & P04U-6 & ACCESS TUBE & ACTIVE & NV ST PLN-NAD27 & $\begin{array}{r}767553.756 \\
798275 \\
\end{array}$ & $\begin{array}{r}707794.9 \\
18041607 \\
\end{array}$ & FT & $\begin{array}{r}115.957265 \\
676 \\
\end{array}$ & $\begin{array}{r}36.856609 \\
165 \\
\end{array}$ & & 3197.17 & FT \\
\hline 153094 & P04U-7 & ACCESS TUBE & ACTIVE & NV ST PLN-NAD27 & \begin{tabular}{|r|}
767424.290 \\
569793 \\
\end{tabular} & \begin{tabular}{|r|}
707688.8 \\
02493216 \\
\end{tabular} & FT & $\begin{array}{r}115.957631 \\
661\end{array}$ & $\begin{array}{r}36.856255 \\
723 \\
\end{array}$ & & 3195.21 & $F T$ \\
\hline 153096 & P04U-9 & ACCESS TUBE & ACTIVE & NV ST PLN-NAD27 & \begin{tabular}{|r|}
767425.549 \\
53431 \\
\end{tabular} & $\begin{array}{r}707786.3 \\
78484254 \\
\end{array}$ & FT & $\begin{array}{r}115.957298 \\
12\end{array}$ & $\begin{array}{r}36.856257 \\
194 \\
\end{array}$ & & 3194.91 & FT \\
\hline 153097 & P04U-10 & ACCESS TUBE & ACTIVE & NV ST PLN-NAD27 & \begin{tabular}{|r|}
767298.877 \\
204496 \\
\end{tabular} & $\begin{array}{r}707706.1 \\
03354855 \\
\end{array}$ & FT & $\begin{array}{r}115.957575 \\
711 \\
\end{array}$ & $\begin{array}{r}36.855910 \\
899 \\
\end{array}$ & & 3193.34 & $F T$ \\
\hline 153099 & P04U-12 & ACCESS TUBE & ACTIVE & NV ST PLN-NAD27 & & & FT & & & & & FT \\
\hline 153100 & P04U-13 & ACCESS TUBE & ACTIVE & NV ST PLN-NAD27 & \begin{tabular}{|r|}
767191.786 \\
081036 \\
\end{tabular} & \begin{tabular}{|r}
707679.6 \\
84190884 \\
\end{tabular} & FT & $\begin{array}{r}115.957668 \\
728 \\
\end{array}$ & $\begin{array}{r}36.855617 \\
292 \\
\end{array}$ & & 3192.29 & FT \\
\hline 153101 & P04U-14 & ACCESS TUBE & ACTIVE & NV ST PLN-NAD27 & \begin{tabular}{|r|}
767193.586 \\
587954 \\
\end{tabular} & $\begin{array}{r}707737.7 \\
17035451 \\
\end{array}$ & FT & $\begin{array}{r}115.957470 \\
33\end{array}$ & $\begin{array}{r}36.855621 \\
055 \\
\end{array}$ & & 3191.84 & FT \\
\hline 153102 & P04U-15 & ACCESS TUBE & ACTIVE & NV ST PLN-NAD27 & \begin{tabular}{|r|}
767187.208 \\
622183 \\
\end{tabular} & \begin{tabular}{|r|}
707800.3 \\
508747 \\
\end{tabular} & FT & $\begin{array}{r}115.957256 \\
415 \\
\end{array}$ & $\begin{array}{r}36.855602 \\
261 \\
\end{array}$ & & 3192.12 & $F T$ \\
\hline 153104 & P04U-17 & ACCESS TUBE & ACTIVE & NV ST PLN-NAD27 & \begin{tabular}{|r|}
767052.261 \\
082182 \\
\end{tabular} & $\begin{array}{r}707727.3 \\
11909032 \\
\end{array}$ & FT & $\begin{array}{r}115.957509 \\
481\end{array}$ & $\begin{array}{r}36.855233 \\
09\end{array}$ & & 3190.26 & FT \\
\hline
\end{tabular}

Data extracted September 2005 from the Bechtel Integrated Data Management System (BEIDMS) 
AREA 5 MONITORING LOCATIONS

\begin{tabular}{|c|c|c|c|c|c|c|c|c|c|c|c|c|}
\hline STATION & STATION ID & TYPE & STATUS & GRID_PLANE & NORTHING & EASTING & UNITS & LONGITUDE & LATITUDE & $\begin{array}{c}\text { GROUND } \\
\text { ELEVATION }\end{array}$ & $\begin{array}{l}\text { REFERENCE } \\
\text { ELEVATION } \\
\end{array}$ & UNITS \\
\hline 153105 & P04U-18 & ACCESS TUBE & ACTIVE & NV ST PLN-NAD27 & $\begin{array}{r}767051.821 \\
721218 \\
\end{array}$ & $\begin{array}{r}707800.8 \\
52192705 \\
\end{array}$ & FT & $\begin{array}{r}115.957258 \\
139 \\
\end{array}$ & $\begin{array}{r}36.855230 \\
385 \\
\end{array}$ & & 3192.33 & FT \\
\hline 153106 & P04U-19 & ACCESS TUBE & ACTIVE & NV ST PLN-NAD27 & $\begin{array}{r}766889.518 \\
073576 \\
\end{array}$ & $\begin{array}{r}707702.2 \\
34736437 \\
\end{array}$ & FT & $\begin{array}{r}115.957599 \\
323 \\
\end{array}$ & $\begin{array}{r}36.854786 \\
596 \\
\end{array}$ & & 3188.35 & FT \\
\hline 153107 & P04U-20 & ACCESS TUBE & ACTIVE & NV ST PLN-NAD27 & $\begin{array}{r}766888.972 \\
818574 \\
\end{array}$ & $\begin{array}{r}707745.2 \\
93565689 \\
\end{array}$ & FT & $\begin{array}{r}115.957452 \\
167 \\
\end{array}$ & $\begin{array}{r}36.854784 \\
222 \\
\end{array}$ & & 3188.71 & $\mathrm{FT}$ \\
\hline 153108 & P04U-21 & ACCESS TUBE & ACTIVE & NV ST PLN-NAD27 & $\begin{array}{r}766890.513 \\
801928 \\
\end{array}$ & \begin{tabular}{|r|}
707794.3 \\
06564241 \\
\end{tabular} & FT & $\begin{array}{r}115.957284 \\
607 \\
\end{array}$ & $\begin{array}{r}36.854787 \\
456 \\
\end{array}$ & & 3188.64 & FT \\
\hline 153109 & P04U-22 & ACCESS TUBE & ACTIVE & NV ST PLN-NAD27 & $\begin{array}{r}766748.026 \\
627134 \\
\end{array}$ & $\begin{array}{r}707701.1 \\
54752472 \\
\end{array}$ & FT & $\begin{array}{r}115.957606 \\
605 \\
\end{array}$ & $\begin{array}{r}36.854397 \\
986 \\
\end{array}$ & & 3186.84 & FT \\
\hline 153110 & P04U-23 & ACCESS TUBE & ACTIVE & NV ST PLN-NAD27 & $\begin{array}{r}766747.382 \\
063871 \\
\end{array}$ & $\begin{array}{r}707744.3 \\
15666184 \\
\end{array}$ & FT & $\begin{array}{r}115.957459 \\
103 \\
\end{array}$ & $\begin{array}{r}36.854395 \\
336 \\
\end{array}$ & & 3186.9 & FT \\
\hline 153111 & P04U-24 & ACCESS TUBE & ACTIVE & NV ST PLN-NAD27 & $\begin{array}{r}766746.522 \\
433184 \\
\end{array}$ & $\begin{array}{r}707792.6 \\
78315807 \\
\end{array}$ & FT & $\begin{array}{r}115.957293 \\
828 \\
\end{array}$ & \begin{tabular}{|r|}
36.854391 \\
99 \\
\end{tabular} & & 3186.88 & FT \\
\hline 153112 & P05U-1 & ACCESS TUBE & ACTIVE & NV ST PLN-NAD27 & \begin{tabular}{|r|}
767691.711 \\
280677 \\
\end{tabular} & $\begin{array}{r}707500.8 \\
6668158 \\
\end{array}$ & FT & $\begin{array}{r}115.958267 \\
236 \\
\end{array}$ & $\begin{array}{r}36.856994 \\
07 \\
\end{array}$ & & 3198.5 & FT \\
\hline 153113 & P05U-2 & ACCESS TUBE & ACTIVE & NV ST PLN-NAD27 & $\begin{array}{r}767690.090 \\
406763 \\
\end{array}$ & \begin{tabular}{|r|}
707535.9 \\
16651519
\end{tabular} & FT & $\begin{array}{r}115.958147 \\
477\end{array}$ & $\begin{array}{r}36.856988 \\
904 \\
\end{array}$ & & 3198.09 & FT \\
\hline 153114 & P05U-3 & ACCESS TUBE & ACTIVE & NV ST PLN-NAD27 & $\begin{array}{r}767687.075 \\
594501 \\
\end{array}$ & $\begin{array}{r}707570.4 \\
14564094 \\
\end{array}$ & FT & $\begin{array}{r}115.958029 \\
64 \\
\end{array}$ & $\begin{array}{r}36.856979 \\
922 \\
\end{array}$ & & 3197.51 & FT \\
\hline 153115 & P05U-4 & ACCESS TUBE & ACTIVE & NV ST PLN-NAD27 & $\begin{array}{r}767568.454 \\
157872 \\
\end{array}$ & $\begin{array}{r}707488.6 \\
09124099 \\
\end{array}$ & FT & $\begin{array}{r}115.958312 \\
257 \\
\end{array}$ & $\begin{array}{r}36.856655 \\
77 \\
\end{array}$ & & 3197.52 & FT \\
\hline 153117 & P05U-6 & ACCESS TUBE & ACTIVE & NV ST PLN-NAD27 & $\begin{array}{r}767565.966 \\
114048 \\
\end{array}$ & \begin{tabular}{|r|}
707568.0 \\
83208468 \\
\end{tabular} & FT & $\begin{array}{r}115.958040 \\
681 \\
\end{array}$ & $\begin{array}{r}36.856647 \\
319 \\
\end{array}$ & & 3197.41 & FT \\
\hline 153118 & NN-1 NORTH & ACCESS TUBE & ACTIVE & NV ST PLN-NAD27 & 768274.83 & \begin{tabular}{|r|}
706467.0 \\
5 \\
\end{tabular} & FT & $\begin{array}{r}115.961786 \\
094 \\
\end{array}$ & $\begin{array}{r}36.858616 \\
697 \\
\end{array}$ & & 3204.88 & FT \\
\hline
\end{tabular}


AREA 5 MONITORING LOCATIONS

\begin{tabular}{|c|c|c|c|c|c|c|c|c|c|c|c|c|}
\hline STATION & STATION ID & TYPE & STATUS & GRID_PLANE & NORTHING & EASTING & UNITS & LONGITUDE & LATITUDE & \begin{tabular}{|l|} 
GROUND \\
ELEVATION
\end{tabular} & $\begin{array}{l}\text { REFERENCE } \\
\text { ELEVATION } \\
\end{array}$ & UNITS \\
\hline 153119 & NE-1 EAST & ACCESS TUBE & ACTIVE & NV ST PLN-NAD27 & 767229.06 & $\begin{array}{r}709430.3 \\
7 \\
\end{array}$ & FT & $\begin{array}{r}115.951684 \\
07 \\
\end{array}$ & $\begin{array}{r}36.855683 \\
873 \\
\end{array}$ & & 3196.62 & FT \\
\hline 153120 & NS-1 SOUTH & ACCESS TUBE & ACTIVE & NV ST PLN-NAD27 & 765790.28 & $\begin{array}{r}708094.0 \\
5 \\
\end{array}$ & FT & $\begin{array}{r}115.956288 \\
091 \\
\end{array}$ & $\begin{array}{r}36.851759 \\
346 \\
\end{array}$ & & 3171.16 & FT \\
\hline 153122 & P06U-1 & ACCESS TUBE & ACTIVE & NV ST PLN-NAD27 & & & FT & & & & & FT \\
\hline 153124 & P06U-3 & ACCESS TUBE & ACTIVE & NV ST PLN-NAD27 & & & FT & & & & & FT \\
\hline 153125 & P06U-4 & ACCESS TUBE & ACTIVE & NV ST PLN-NAD27 & & & FT & & & & & FT \\
\hline 153067 & P03U-23 & ACCESS TUBE & ACTIVE & NV ST PLN-NAD27 & 767770 & 709259 & FT & $\begin{array}{r}115.952255 \\
967 \\
\end{array}$ & $\begin{array}{r}36.857173 \\
182 \\
\end{array}$ & & & FT \\
\hline 159201 & CANE SPRING \#1 & $\mathrm{BIO}$ & & NV ST PLN-NAD27 & & & FT & & & & & FT \\
\hline 159202 & $\begin{array}{l}\text { CAMBRIC DITCH/O.0 MI FROM } \\
\text { PUMP }\end{array}$ & $\mathrm{BIO}$ & & NV ST PLN-NAD27 & & & FT & & & & & FT \\
\hline 159241 & $\begin{array}{l}\text { CAMBRIC DITCH/0.3 MI FROM } \\
\text { PUMP }\end{array}$ & $\mathrm{BIO}$ & & NV ST PLN-NAD27 & & & FT & & & & & FT \\
\hline 159242 & $\begin{array}{l}\text { CAMBRIC DITCH/0.7 MI FROM } \\
\text { PUMP }\end{array}$ & $\mathrm{BIO}$ & & NV ST PLN-NAD27 & & & FT & & & & & FT \\
\hline 159243 & $\begin{array}{l}\text { CAMBRIC DITCH/1.0 MI FROM } \\
\text { PUMP }\end{array}$ & $\mathrm{BIO}$ & & NV ST PLN-NAD27 & & & FT & & & & & FT \\
\hline 159741 & CANE SPRING \#2 & $\mathrm{BIO}$ & & NV ST PLN-NAD27 & & & FT & & & & & FT \\
\hline 159742 & CANE SPRING \#3 & $\mathrm{BIO}$ & & NV ST PLN-NAD27 & & & FT & & & & & FT \\
\hline 160021 & CAMBRIC DITCH/10 M FROM PUMP & DITCH & & NV ST PLN-NAD27 & & & FT & & & & & FT \\
\hline 160022 & $\begin{array}{l}\text { CAMBRIC DITCH/200 M FROM } \\
\text { PUMP }\end{array}$ & DITCH & & NV ST PLN-NAD27 & & & FT & & & & & FT \\
\hline 160023 & $\begin{array}{l}\text { CAMBRIC DITCH/500 M FROM } \\
\text { PUMP }\end{array}$ & DITCH & & NV ST PLN-NAD27 & & & FT & & & & & FT \\
\hline 160024 & $\begin{array}{l}\text { CAMBRIC DITCH/OUTFLOW TO } \\
\text { PLAYA }\end{array}$ & DITCH & & NV ST PLN-NAD27 & & & FT & & & & & FT \\
\hline 160441 & $\begin{array}{l}\text { CAMBRIC DITCH/0.1 MI FROM } \\
\text { PUMP }\end{array}$ & $\mathrm{BIO}$ & & NV ST PLN-NAD27 & & & FT & & & & & FT \\
\hline
\end{tabular}


AREA 5 MONITORING LOCATIONS

\begin{tabular}{|c|c|c|c|c|c|c|c|c|c|c|c|c|}
\hline STATION & STATION ID & TYPE & STATUS & GRID_PLANE & NORTHING & EASTING & UNITS & LONGITUDE & LATITUDE & $\begin{array}{c}\text { GROUND } \\
\text { ELEVATION }\end{array}$ & $\begin{array}{l}\text { REFERENCE } \\
\text { ELEVATION }\end{array}$ & UNITS \\
\hline 897469 & BLDG 5-07 WOMENS RESTROOM & $\begin{array}{l}\text { POT WTR END } \\
\text { PT }\end{array}$ & & & & & & & & & & \\
\hline 895644 & ER-5-3 & BH EM & ACTIVE & NV ST PLN-NAD27 & 773578 & 713137 & FT & -115.938849 & 36.873045 & 3334 & 3334 & FT \\
\hline 895645 & ER-5-3 \#2 & $\mathrm{BH}$ EM & ACTIVE & NV ST PLN-NAD27 & 773586 & 713037 & FT & -115.939191 & 36.873069 & 3334 & 3334 & FT \\
\hline 727526 & WATER WELL 5B-AMS & AMS & & & & & FT & & & & & FT \\
\hline 727528 & WEF NORTH-ETLD & ETLD & ACTIVE & $\begin{array}{l}\text { UTM Z11 meters } \\
\text { WGS84 }\end{array}$ & 4078922 & 593411 & $F T$ & 115.95221 & 36.8516 & 3158 & & FT \\
\hline 727529 & WEF SOUTH-ETLD & ETLD & ACTIVE & $\begin{array}{l}\text { UTM Z11 meters } \\
\text { WGS84 }\end{array}$ & 4078828 & 593382 & FT & 115.95254 & 36.85075 & 3157 & & FT \\
\hline 728704 & P03U-22 & ACCESS TUBE & ACTIVE & |NV ST PLN-NAD27 & 767770 & 709228 & FT & $\begin{array}{r}115.952361 \\
925\end{array}$ & $\begin{array}{r}36.857173 \\
818\end{array}$ & & & FT \\
\hline 749827 & $\begin{array}{l}\text { AREA } 5 \text { NORTH PER DELETE } \\
\text { LATER }\end{array}$ & ACCESS TUBE & ACTIVE & NV ST PLN-NAD27 & & & FT & & & & & FT \\
\hline 749828 & NE-1 EAST DELETE LATER & ACCESS TUBE & ACTIVE & NV ST PLN-NAD27 & & & FT & & & & & FT \\
\hline 749829 & NW-1 WEST DELETE LATER & ACCESS TUBE & ACTIVE & NV ST PLN-NAD27 & & & FT & & & & & FT \\
\hline 749830 & NS-1 SOUTH DELETE LATER & ACCESS TUBE & ACTIVE & NV ST PLN-NAD27 & & & FT & & & & & FT \\
\hline 830285 & BUILDING 5-6 ROOM 4 & AMS & & & & & FT & & & & & FT \\
\hline 830286 & GCD TRAILER & AMS & & & & & $\mathrm{FT}$ & & & & & FT \\
\hline 830292 & PIT 6 & ETLD & INACTIVE & NV ST PLN-NAD27 & & & FT & & & & & FT \\
\hline 830294 & TRENCH 8 SOUTH & ETLD & INACTIVE & NV ST PLN-NAD27 & & & FT & & & & & FT \\
\hline 830296 & WEF COMPOUND FENCE SOUTH & ETLD & INACTIVE & NV ST PLN-NAD27 & & & FT & & & & & FT \\
\hline 870408 & BUILDING 5-7 & \begin{tabular}{|l} 
POT WTR END \\
PT \\
\end{tabular} & & NV ST PLN-NAD27 & & & FT & & & & & FT \\
\hline 878767 & 90 DAY STORAGE AREA & 90 DAY PAD & & & & & & & & & & \\
\hline 153046 & P03U-2 & ACCESS TUBE & ACTIVE & NV ST PLN-NAD27 & 767938 & 709286 & FT & $\begin{array}{r}115.952159 \\
385\end{array}$ & $\begin{array}{r}36.857634 \\
07\end{array}$ & & & FT \\
\hline
\end{tabular}

Data extracted September 2005 from the Bechtel Integrated Data Management System (BEIDMS) 
AREA 5 MONITORING LOCATIONS

\begin{tabular}{|c|c|c|c|c|c|c|c|c|c|c|c|c|}
\hline STATION & STATION ID & TYPE & STATUS & GRID_PLANE & NORTHING & EASTING & UNITS & LONGITUDE & LATITUDE & $\begin{array}{c}\text { GROUND } \\
\text { ELEVATION }\end{array}$ & $\begin{array}{l}\text { REFERENCE } \\
\text { ELEVATION }\end{array}$ & UNITS \\
\hline 153053 & P03U-9 & ACCESS TUBE & ACTIVE & NV ST PLN-NAD27 & 767883 & 709286 & FT & $\begin{array}{r}115.952160 \\
792\end{array}$ & $\begin{array}{r}36.857483 \\
003 \\
\end{array}$ & & & FT \\
\hline 153061 & P03U-17 & ACCESS TUBE & ACTIVE & NV ST PLN-NAD27 & 767854 & 709230 & FT & $\begin{array}{r}115.952352 \\
941\end{array}$ & $\begin{array}{r}36.857404 \\
498 \\
\end{array}$ & & & FT \\
\hline 153071 & P03U-2A & ACCESS TUBE & ACTIVE & NV ST PLN-NAD27 & 767845.41 & $\begin{array}{r}709359.7 \\
9 \\
\end{array}$ & FT & $\begin{array}{r}115.951909 \\
539\end{array}$ & \begin{tabular}{|r|}
36.857378 \\
24 \\
\end{tabular} & & 3213.01 & FT \\
\hline 153079 & P01U-6 & ACCESS TUBE & ACTIVE & NV ST PLN-NAD27 & $\begin{array}{r}767034.008 \\
598411 \\
\end{array}$ & $\begin{array}{r}708539.6 \\
61343166 \\
\end{array}$ & FT & $\begin{array}{r}115.954733 \\
414 \\
\end{array}$ & $\begin{array}{r}36.855166 \\
379 \\
\end{array}$ & & 3193.79 & FT \\
\hline 153087 & P02U-8 & ACCESS TUBE & ACTIVE & NV ST PLN-NAD27 & $\begin{array}{r}766785.103 \\
000653 \\
\end{array}$ & $\begin{array}{r}708139.3 \\
40387388 \\
\end{array}$ & FT & $\begin{array}{r}115.956108 \\
002 \\
\end{array}$ & $\begin{array}{r}36.854490 \\
89 \\
\end{array}$ & & 3191.77 & FT \\
\hline 153095 & P04U-8 & ACCESS TUBE & ACTIVE & NV ST PLN-NAD27 & $\begin{array}{r}767425.101 \\
944558 \\
\end{array}$ & \begin{tabular}{|r|}
707730.4 \\
6259429 \\
\end{tabular} & FT & $\begin{array}{r}115.957489 \\
249 \\
\end{array}$ & $\begin{array}{r}36.856257 \\
103 \\
\end{array}$ & & 3194.94 & FT \\
\hline 153103 & P04U-16 & ACCESS TUBE & ACTIVE & NV ST PLN-NAD27 & $\begin{array}{r}767049.664 \\
901581 \\
\end{array}$ & $\begin{array}{r}707694.3 \\
89298308 \\
\end{array}$ & FT & $\begin{array}{r}115.957622 \\
074 \\
\end{array}$ & $\begin{array}{r}36.855226 \\
63 \\
\end{array}$ & & 3190.3 & FT \\
\hline 153123 & P06U-2 & ACCESS TUBE & ACTIVE & NV ST PLN-NAD27 & & & FT & & & & & FT \\
\hline 153066 & P03U-22 DELETE LATER & ACCESS TUBE & ACTIVE & NV ST PLN-NAD27 & 767770 & 709228 & FT & $\begin{array}{r}115.952361 \\
925\end{array}$ & $\begin{array}{r}36.857173 \\
818\end{array}$ & & & FT \\
\hline 891445 & NEUTRON CALIBRATION DATA & $\mathrm{BH}$ & & & & & & & & & & \\
\hline 153121 & NW-1 WEST & ACCESS TUBE & ACTIVE & NV ST PLN-NAD27 & 766695.75 & $\begin{array}{r}706971.1 \\
1 \\
\end{array}$ & FT & $\begin{array}{r}115.960103 \\
125 \\
\end{array}$ & $\begin{array}{r}36.854269 \\
238 \\
\end{array}$ & & 3177.67 & FT \\
\hline 830293 & PIT 7 & ETLD & INACTIVE & NV ST PLN-NAD27 & & & FT & & & & & FT \\
\hline 830291 & BLDG 5-31 & ETLD & ACTIVE & $\begin{array}{l}\text { UTM Z11 meters } \\
\text { WGS84 }\end{array}$ & 4078981 & 593438 & FT & 115.9519 & 36.852124 & 3174 & & FT \\
\hline 10876 & UE-5J & BH EXPL & ACTIVE & NV ST PLN-NAD27 & 775001 & 684500 & FT & -116.03672 & 36.877513 & 3578 & 3578 & FT \\
\hline 10880 & U-5LS & BH EMP & ACTIVE & NV ST PLN-NAD27 & 772700 & 713499 & FT & -115.937635 & 36.870626 & 3324 & 3324 & $F T$ \\
\hline
\end{tabular}

Data extracted September 2005 from the Bechtel Integrated Data Management System (BEIDMS)

C-16 
AREA 5 MONITORING LOCATIONS

\begin{tabular}{|c|c|c|c|c|c|c|c|c|c|c|c|c|}
\hline STATION & STATION ID & TYPE & STATUS & GRID_PLANE & NORTHING & EASTING & UNITS & LONGITUDE & LATITUDE & $\begin{array}{c}\text { GROUND } \\
\text { ELEVATION }\end{array}$ & $\begin{array}{l}\text { REFERENCE } \\
\text { ELEVATION } \\
\end{array}$ & UNITS \\
\hline 153116 & P05U-5 & ACCESS TUBE & ACTIVE & NV ST PLN-NAD27 & $\begin{array}{r}767566.523 \\
288953 \\
\end{array}$ & $\begin{array}{r}707531.4 \\
34148736 \\
\end{array}$ & FT & $\begin{array}{r}115.958165 \\
932\end{array}$ & $\begin{array}{r}36.856649 \\
595 \\
\end{array}$ & & 3197.6 & FT \\
\hline 153086 & P02U-7 & ACCESS TUBE & ACTIVE & NV ST PLN-NAD27 & $\begin{array}{r}766804.114 \\
301895 \\
\end{array}$ & $\begin{array}{r}708104.5 \\
64590544 \\
\end{array}$ & FT & $\begin{array}{r}115.956226 \\
377 \\
\end{array}$ & $\begin{array}{r}36.854543 \\
818 \\
\end{array}$ & & 3193.19 & FT \\
\hline 153098 & P04U-11 & ACCESS TUBE & ACTIVE & NV ST PLN-NAD27 & $\begin{array}{r}767299.282 \\
727368 \\
\end{array}$ & $\begin{array}{r}707738.7 \\
93471482 \\
\end{array}$ & FT & $\begin{array}{r}115.957463 \\
968 \\
\end{array}$ & $\begin{array}{r}36.855911 \\
348 \\
\end{array}$ & & 3193.43 & FT \\
\hline 153070 & P03U-1A & ACCESS TUBE & ACTIVE & NV ST PLN-NAD27 & 767906 & $\begin{array}{r}709357.4 \\
1\end{array}$ & FT & $\begin{array}{r}115.951916 \\
124\end{array}$ & $\begin{array}{r}36.857544 \\
711 \\
\end{array}$ & & 3212.58 & FT \\
\hline 153081 & P02U-2 & ACCESS TUBE & ACTIVE & NV ST PLN-NAD27 & $\begin{array}{r}767216.108 \\
962373 \\
\end{array}$ & $\begin{array}{r}708255.0 \\
38398782 \\
\end{array}$ & FT & $\begin{array}{r}115.955701 \\
593 \\
\end{array}$ & $\begin{array}{r}36.855672 \\
367 \\
\end{array}$ & & 3197.62 & FT \\
\hline 152082 & UE5PW-3 PPT & PPT & ACTIVE & NV ST PLN-NAD27 & 771291 & 703460 & FT & $\begin{array}{r}115.971989 \\
373 \\
\end{array}$ & $\begin{array}{r}36.866961 \\
624 \\
\end{array}$ & & 1005 & METERS \\
\hline 153045 & P03U-1 & ACCESS TUBE & ACTIVE & NV ST PLN-NAD27 & 767966 & 709286 & FT & $\begin{array}{r}115.952158 \\
669 \\
\end{array}$ & $\begin{array}{r}36.857710 \\
978 \\
\end{array}$ & & & FT \\
\hline 153057 & P03U-13 & ACCESS TUBE & ACTIVE & NV ST PLN-NAD27 & 767854 & 709258 & FT & $\begin{array}{r}115.952257 \\
237\end{array}$ & $\begin{array}{r}36.857403 \\
924\end{array}$ & & & FT \\
\hline 727527 & WATER WELL 5B-ETLD & ETLD & ACTIVE & $\begin{array}{l}\text { UTM Z11 meters } \\
\text { WGS84 }\end{array}$ & 4073315 & 591903 & FT & 115.9698 & 36.801211 & 3092 & & FT \\
\hline 830295 & WEF COMPOUND FENCE NORTH & ETLD & INACTIVE & NV ST PLN-NAD27 & & & FT & & & & & FT \\
\hline 902101 & GCD05U-10A & SOIL GAS & ACTIVE & NV ST PLN-NAD27 & 767417 & 708120 & FT & & & 3178 & & FT \\
\hline 902102 & GCD05U-10B & SOIL GAS & ACTIVE & NV ST PLN-NAD27 & 767417 & 708120 & FT & & & 3178 & & FT \\
\hline 902103 & GCD05U-20A & SOIL GAS & ACTIVE & NV ST PLN-NAD27 & 767417 & 708120 & FT & & & 3178 & & FT \\
\hline 902105 & GCD05U-30A & SOIL GAS & ACTIVE & NV ST PLN-NAD27 & 767417 & 708120 & FT & & & 3178 & & FT \\
\hline 902106 & GCD05U-30B & SOIL GAS & ACTIVE & NV ST PLN-NAD27 & 767417 & 708120 & FT & & & 3178 & & FT \\
\hline
\end{tabular}

Data extracted September 2005 from the Bechtel Integrated Data Management System (BEIDMS) 
AREA 5 MONITORING LOCATIONS

\begin{tabular}{|c|c|c|c|c|c|c|c|c|c|c|c|c|}
\hline STATION & STATION ID & TYPE & STATUS & GRID_PLANE & NORTHING & EASTING & UNITS & LONGITUDE & LATITUDE & $\begin{array}{c}\text { GROUND } \\
\text { ELEVATION }\end{array}$ & $\begin{array}{c}\text { REFERENCE } \\
\text { ELEVATION } \\
\end{array}$ & UNITS \\
\hline 902107 & GCD05U-40A & SOIL GAS & ACTIVE & NV ST PLN-NAD27 & 767417 & 708120 & FT & & & 3178 & & FT \\
\hline 902108 & GCD05U-40B & SOIL GAS & ACTIVE & NV ST PLN-NAD27 & 767417 & 708120 & FT & & & 3178 & & FT \\
\hline 902109 & GCD05U-50A & SOIL GAS & ACTIVE & NV ST PLN-NAD27 & 767417 & 708120 & FT & & & 3178 & & FT \\
\hline 902110 & GCD05U-50B & SOIL GAS & ACTIVE & NV ST PLN-NAD27 & 767417 & 708120 & FT & & & 3178 & & FT \\
\hline 902111 & GCD05U-65A & SOIL GAS & ACTIVE & NV ST PLN-NAD27 & 767417 & 708120 & FT & & & 3178 & & FT \\
\hline 902112 & GCD05U-65B & SOIL GAS & ACTIVE & NV ST PLN-NAD27 & 767417 & 708120 & FT & & & 3178 & & FT \\
\hline 902113 & GCD05U-85A & SOIL GAS & ACTIVE & NV ST PLN-NAD27 & 767417 & 708120 & FT & & & 3178 & & FT \\
\hline 902114 & GCD05U-85B & SOIL GAS & ACTIVE & NV ST PLN-NAD27 & 767417 & 708120 & FT & & & 3178 & & FT \\
\hline 902116 & GCD05U-119A & SOIL GAS & ACTIVE & NV ST PLN-NAD27 & 767417 & 708120 & FT & & & 3178 & & FT \\
\hline 902115 & GCD05U-110A & SOIL GAS & ACTIVE & NV ST PLN-NAD27 & 767417 & 708120 & FT & & & 3178 & & FT \\
\hline 903964 & RWMS LARREA \#1 & $\mathrm{BIO}$ & & NV ST PLN-NAD27 & & & FT & & & & & FT \\
\hline 903965 & RWMS LARREA \#2 & $\mathrm{BIO}$ & & NV ST PLN-NAD27 & & & FT & & & & & FT \\
\hline 903966 & RWMS LARREA \#3 & $\mathrm{BIO}$ & & NV ST PLN-NAD27 & & & FT & & & & & FT \\
\hline 903967 & RWMS LARREA \#4 & $\mathrm{BIO}$ & & NV ST PLN-NAD27 & & & FT & & & & & FT \\
\hline 903968 & RWMS SALSOLA \#1 & $\mathrm{BIO}$ & & NV ST PLN-NAD27 & & & FT & & & & & FT \\
\hline 903969 & RWMS SALSOLA \#2 & $\mathrm{BIO}$ & & NV ST PLN-NAD27 & & & FT & & & & & FT \\
\hline 903970 & RWMS SALSOLA \#3 & $\mathrm{BIO}$ & & NV ST PLN-NAD27 & & & FT & & & & & FT \\
\hline 903971 & RWMS SALSOLA \#4 & $\mathrm{BIO}$ & & NV ST PLN-NAD27 & & & FT & & & & & FT \\
\hline 903972 & RWMS ANNUAL \#1 & $\mathrm{BIO}$ & & NV ST PLN-NAD27 & & & FT & & & & & FT \\
\hline 903973 & RWMS ANNUAL \#2 & $\mathrm{BIO}$ & & NV ST PLN-NAD27 & & & FT & & & & & FT \\
\hline
\end{tabular}

Data extracted September 2005 from the Bechtel Integrated Data Management System (BEIDMS) 
AREA 5 MONITORING LOCATIONS

\begin{tabular}{|c|c|c|c|c|c|c|c|c|c|c|c|c|}
\hline STATION & STATION ID & TYPE & STATUS & GRID_PLANE & NORTHING & EASTING & UNITS & LONGITUDE & LATITUDE & $\begin{array}{c}\text { GROUND } \\
\text { ELEVATION }\end{array}$ & \begin{tabular}{|c|} 
REFERENCE \\
ELEVATION
\end{tabular} & UNITS \\
\hline 903974 & RWMS ANNUAL \#3 & BIO & & NV ST PLN-NAD27 & & & FT & & & & & FT \\
\hline 903985 & RWMS ATRIPLEX \#1 & BIO & & NV ST PLN-NAD27 & & & FT & & & & & FT \\
\hline 903986 & RWMS ATRIPLEX \#2 & $\mathrm{BIO}$ & & NV ST PLN-NAD27 & & & FT & & & & & FT \\
\hline 903987 & RWMS ATRIPLEX $\# 3$ & BIO & & NV ST PLN-NAD27 & & & FT & & & & & FT \\
\hline 904021 & TRENCH 1 & BIO & & NV ST PLN-NAD27 & & & FT & & & & & FT \\
\hline 904022 & TRENCH 4 & $\mathrm{BIO}$ & & NV ST PLN-NAD27 & & & FT & & & & & FT \\
\hline 904023 & PIT 1 & $\mathrm{BIO}$ & & NV ST PLN-NAD27 & & & FT & & & & & FT \\
\hline 904037 & GCD PLANTS & $\mathrm{BIO}$ & & NV ST PLN-NAD27 & & & FT & & & & & FT \\
\hline 904038 & CONTROL & BIO & & NV ST PLN-NAD27 & & & FT & & & & & FT \\
\hline 904039 & PIT 3 & BIO & & NV ST PLN-NAD27 & & & FT & & & & & FT \\
\hline 904040 & TRENCH 6 & BIO & & NV ST PLN-NAD27 & & & FT & & & & & FT \\
\hline 1709548 & GCD05U-110B & SOIL GAS & ACTIVE & NV ST PLN-NAD27 & & & FT & & & & & FT \\
\hline 2163341 & ER-5-2 & BH EM & & & 732500 & 682600 & & -116.044163 & 36.760807 & & & \\
\hline 2163342 & ER-5-3 \#3 & BH EM & & & 773586 & 713037 & & -115.939191 & 36.873069 & & & \\
\hline 2163343 & ER-5-4 & BH EM & & & 755810 & 705950 & & -115.963866 & 36.82439 & & & \\
\hline 2163344 & ER-5-4 \#2 & BH EM & & & 755710 & 705950 & & -115.963869 & 36.824115 & & & \\
\hline 2163458 & WEF WEST ETLD & ETLD & ACTIVE & $\begin{array}{l}\text { UTM Z11 meters } \\
\text { WGS84 }\end{array}$ & 4078910 & 593310 & & 115.95334 & 36.8515 & 3000 & & FT \\
\hline
\end{tabular}


AREA 5 MONITORING LOCATIONS

\begin{tabular}{|c|c|c|c|c|c|c|c|c|c|c|c|c|}
\hline STATION & STATION ID & TYPE & STATUS & GRID_PLANE & NORTHING & EASTING & UNITS & LONGITUDE & LATITUDE & $\begin{array}{c}\text { GROUND } \\
\text { ELEVATION } \\
\end{array}$ & $\begin{array}{r}\text { REFERENCE } \\
\text { ELEVATION } \\
\end{array}$ & UNITS \\
\hline 2165072 & TRU PAD-RCRA & DRUM-55GAL & & NV ST PLN-NAD27 & & & FT & & & & & FT \\
\hline 2165077 & TRU PAD RCRA & DRUM & & NV ST PLN-NAD27 & & & FT & & & & & FT \\
\hline 2173067 & $\begin{array}{l}\text { MERC HWY 1MI N OF CANE SPRG } \\
\text { RD }\end{array}$ & $\mathrm{BIO}$ & & & 4080000 & 588400 & & & & & & METERS \\
\hline 2177766 & AREA 5 FLUME & FLUME & & & & & & & & & & \\
\hline 2177767 & NORTH WEIGHING LYSIMETER & LYSIMETER & & & & & & & & & & \\
\hline 2177768 & SOUTH WEIGHING LYSIMETER & LYSIMETER & & & & & & & & & & \\
\hline 2178488 & PO5U-VZMF-1 & VZM & & & & & & & & & & \\
\hline 2178489 & PO5U-VZMF-2 & VZM & & & & & & & & & & \\
\hline 2178487 & PO5U-VZMC-1 & VZM & & & & & & & & & & \\
\hline 2178490 & PO5U-VZMF-3 & VZM & & & & & & & & & & \\
\hline 2178491 & PO5U-VZMF-4 & VZM & & & & & & & & & & \\
\hline 2178492 & PO5U-VZMF-5 & VZM & & & & & & & & & & \\
\hline 2178493 & PO5U-VZMF-6 & VZM & & & & & & & & & & \\
\hline 2178494 & PO4U-VZMC-1 & VZM & & & & & & & & & & \\
\hline 2178495 & PO3U-VZMC-1 & VZM & & & & & & & & & & \\
\hline 2178496 & PO3U-VZMC-2 & VZM & & & & & & & & & & \\
\hline 2178497 & PO3U-VZMF-1 & VZM & & & & & & & & & & \\
\hline 2178498 & PO3U-VZMF-2 & VZM & & & & & & & & & & \\
\hline 2178499 & PO3U-VZMF-3 & VZM & & & & & & & & & & \\
\hline 2181862 & UE5PW-1 ETLD & ETLD & INACTIVE & & 765761 & 709890 & & & 36.851662 & & & \\
\hline 2181863 & SC RWMS ETLD & ETLD & INACTIVE & & 765990 & 708249 & & & 36.852304 & & & \\
\hline 2181864 & WC RWMS ETLD & ETLD & INACTIVE & & 766976 & 707400 & & & 36.85503 & & & \\
\hline 2181865 & UE5PW-3 ETLD & ETLD & INACTIVE & & 771202 & 703602 & & & 36.866714 & & & \\
\hline 2181866 & NE RWMS ETLD & ETLD & INACTIVE & & 767977 & 709399 & & & 36.857738 & & & \\
\hline 2181867 & LYSIMETER ETLD & ETLD & INACTIVE & & 765941 & 705903 & & & 36.852217 & & & \\
\hline 2181869 & S P01U ETLD & ETLD & INACTIVE & NV ST PLN-NAD27 & 766611 & 708436 & & & 36.854006 & 3202 & & FT \\
\hline 902104 & GCD05U-20B & SOIL GAS & ACTIVE & NV ST PLN-NAD27 & 767417 & 708120 & FT & & & 3178 & & FT \\
\hline
\end{tabular}


AREA 5 MONITORING LOCATIONS

\begin{tabular}{|c|c|c|c|c|c|c|c|c|c|c|c|c|}
\hline STATION & STATION ID & TYPE & STATUS & GRID_PLANE & NORTHING & EASTING & UNITS & LONGITUDE & LATITUDE & $\begin{array}{c}\text { GROUND } \\
\text { ELEVATION }\end{array}$ & $\begin{array}{l}\text { REFERENCE } \\
\text { ELEVATION } \\
\end{array}$ & UNITS \\
\hline 2183005 & UE5PW-1 CALPIT VZM & VZM & & & & & & & & & & \\
\hline 2183006 & PIT 5 NORTH VZM STATION & VZM & & & & & & & & & & \\
\hline 2183007 & PIT 5 SOUTH VZM STATION & VZM & & & & & & & & & & \\
\hline 2183008 & PIT3N VZM STATION & VZM & & & & & & & & & & \\
\hline 2183009 & PIT3S VZM STATION & VZM & & & & & & & & & & \\
\hline 2183010 & PIT3F VZM STATION & VZM & & & & & & & & & & \\
\hline 2189535 & BOOSTER TANK & ABOVE TANK & & & & & & & & & & \\
\hline 2190028 & BLDG 5-32 & $\begin{array}{l}\text { POT WTR END } \\
\text { PT } \\
\end{array}$ & ACTIVE & NV ST PLN-NAD27 & & & FT & & & & & FT \\
\hline 2196225 & RWMS BLDG 5-18 SEPTIC SYSTEM & SSS & & & & & & & & & & \\
\hline 2199116 & SUGAR BUNKER NORTH & AMS & ACTIVE & & 763949 & 707789 & & $\begin{array}{r}115.957382 \\
306 \\
\end{array}$ & $\begin{array}{r}36.846704 \\
008 \\
\end{array}$ & 3156 & & FT \\
\hline 2198301 & TRENCH 3 & $\mathrm{BIO}$ & & NV ST PLN-NAD27 & & & FT & & & & & FT \\
\hline 2200120 & RWMS EXPANSION NW & ETLD & ACTIVE & $\begin{array}{l}\text { UTM Z11 meters } \\
\text { WGS84 }\end{array}$ & 4080242 & 592744 & FT & 115.95953 & 36.86356 & 3235 & & FT \\
\hline 2200121 & RWMS EXPANSION NE & ETLD & ACTIVE & $\begin{array}{l}\text { UTM Z11 meters } \\
\text { WGS84 }\end{array}$ & 4080243 & 593403 & FT & 115.95213 & 36.8635 & 3234 & & FT \\
\hline 2201897 & HAZ WASTE ACCUM AREA & DRUM & & & & & & & & & & \\
\hline 2229815 & C-1 SOUTH TANK & DW TANK & & & & & & & & & & \\
\hline 10873 & U-5I CABLE HOLE \#2 & BH CABLE & PLUGGED & NV ST PLN-NAD27 & 774854 & 709462 & FT & -115.95138 & 36.876626 & 3408 & 3408 & FT \\
\hline 10904 & U-5 GCDT \#1 DISPOSAL FACILITY & BH DISPOSAL & ACTIVE & NV ST PLN-NAD27 & 770001 & 710000 & FT & -115.949666 & 36.863285 & 3242 & 3242 & FT \\
\hline 2181870 & N P01U ETLD & ETLD & INACTIVE & \begin{tabular}{|l|} 
NVST PLN- \\
NAD27/WGS84
\end{tabular} & 767210 & 708624 & & & 36.855648 & 3190 & & FT \\
\hline 2181871 & W P02U ETLD & ETLD & INACTIVE & NV ST PLN-NAD27 & 767030 & 708030 & & & 36.855165 & 3189 & & FT \\
\hline 2181868 & W P03U ETLD & ETLD & INACTIVE & NV ST PLN-NAD27 & 767921 & 708090 & & & 36.857611 & 3190 & & FT \\
\hline 2251981 & CLASSIFIED AREA & $\mathrm{BIO}$ & & NV ST PLN-NAD27 & & & FT & & & & & FT \\
\hline 2251982 & PIT 2 & $\mathrm{BIO}$ & & NV ST PLN-NAD27 & & & FT & & & & & FT \\
\hline 2262383 & C-1 WELL HEAD & DW TANK & & & & & & & & & & \\
\hline
\end{tabular}

Data extracted September 2005 from the Bechtel Integrated Data Management System (BEIDMS) 
AREA 5 MONITORING LOCATIONS

\begin{tabular}{|c|c|c|c|c|c|c|c|c|c|c|c|c|}
\hline STATION & STATION ID & TYPE & STATUS & GRID_PLANE & NORTHING & EASTING & UNITS & LONGITUDE & LATITUDE & $\begin{array}{c}\text { GROUND } \\
\text { ELEVATION }\end{array}$ & \begin{tabular}{|} 
REFERENCE \\
ELEVATION
\end{tabular} & UNITS \\
\hline 2265021 & BUILDING 5-19 & $\begin{array}{l}\text { POT WTR END } \\
\text { PT }\end{array}$ & & NV ST PLN-NAD27 & & & FT & & & & & FT \\
\hline 2268851 & FRENCHMAN LAKE & ETLD & ACTIVE & $\begin{array}{l}\text { UTM Z11 meters } \\
\text { WGS84 }\end{array}$ & 4072971 & 595499 & & 115.92954 & 36.79775 & 3080 & & FT \\
\hline 2278453 & $\mathrm{JP}-8$ & SSS & & & & & & & & & & \\
\hline 2627375 & AREA 5 RWMS & ETLD & INACTIVE & & & & & & & & & \\
\hline 2798983 & MERCURY HIGHWAY & $\mathrm{BIO}$ & & & & & & & & & & \\
\hline 2807741 & P01U RADON & SOIL GAS & & & & & & & & & & \\
\hline 2807742 & CLASSIFIED WASTE AREA & SOIL GAS & & & & & & & & & & \\
\hline 2807743 & GCD RADON & SOIL GAS & & & & & & & & & & \\
\hline 2807744 & GCDT RADON & SOIL GAS & ACTIVE & NV ST PLN-NAD27 & 770001 & 710000 & FT & -115.949666 & 36.863285 & 3242 & 3242 & FT \\
\hline 2807745 & LYSIMETER RADON & SOIL GAS & INACTIVE & & 765941 & 705903 & & & \begin{tabular}{|r|}
36.852217 \\
83 \\
\end{tabular} & & & \\
\hline 2807746 & P02U RADON & SOIL GAS & & & & & & & & & & \\
\hline 2807747 & UE5PW-3 RADON & SOIL GAS & INACTIVE & & 771202 & 703602 & & & \begin{tabular}{|r|}
36.866714 \\
37 \\
\end{tabular} & & & \\
\hline 2807748 & UE5PW-1 RADON & SOIL GAS & INACTIVE & & 765761 & 709890 & & & $\begin{array}{r}36.851662 \\
69 \\
\end{array}$ & & & \\
\hline 2807749 & PIT 6 RADON & SOIL GAS & INACTIVE & NV ST PLN-NAD27 & & & FT & & & & & FT \\
\hline 2807750 & TRENCH 1 RADON & SOIL GAS & & NV ST PLN-NAD27 & & & FT & & & & & FT \\
\hline 2829721 & CANE SPRING - BIOTA & $\mathrm{BIO}$ & & NV ST PLN-NAD27 & & & FT & & & & & FT \\
\hline 2845955 & 5B WELL HOUSE & WL POT & ACTIVE & & & & FT & & & & & \\
\hline 2845956 & 5B WATER LINE & WL POT & ACTIVE & & & & $\mathrm{FT}$ & & & & & \\
\hline 2858802 & PIT 3 SUMP & DRUM & & & & & & & & & & \\
\hline 2859421 & CAU-140 SOIL DRUM 1 & DRUM-55GAL & & & & & & & & & & \\
\hline 2859422 & CAU-140 SOIL DRUM 2 & DRUM-55GAL & & & & & & & & & & \\
\hline 2859423 & CAU-140 SOIL DRUM 3 & DRUM-55GAL & & & & & & & & & & \\
\hline 2859424 & CAU-140 SOIL DRUM 4 & DRUM-55GAL & & & & & & & & & & \\
\hline 2859425 & CAU-140 SOIL DRUM 5 & DRUM-55GAL & & & & & & & & & & \\
\hline 2859426 & CAU-140 SOIL DRUM 6 & DRUM-55GAL & & & & & & & & & & \\
\hline 2859427 & CAU-140 SOIL DRUM 7 & DRUM-55GAL & & & & & & & & & & \\
\hline
\end{tabular}


AREA 5 MONITORING LOCATIONS

\begin{tabular}{|c|c|c|c|c|c|c|c|c|c|c|c|c|}
\hline STATION & STATION ID & TYPE & STATUS & GRID_PLANE & NORTHING & EASTING & UNITS & LONGITUDE & LATITUDE & $\begin{array}{c}\text { GROUND } \\
\text { ELEVATION }\end{array}$ & $\begin{array}{l}\text { REFERENCE } \\
\text { ELEVATION }\end{array}$ & UNITS \\
\hline 2859428 & CAU-140 SOIL DRUM 8 & DRUM-55GAL & & & & & & & & & & \\
\hline 2859429 & CAU-140 SOIL DRUM 9 & DRUM-55GAL & & & & & & & & & & \\
\hline 2859430 & CAU-140 SOIL DRUM 10 & DRUM-55GAL & & & & & & & & & & \\
\hline 2859431 & CAU-140 SOIL DRUM 11 & DRUM-55GAL & & & & & & & & & & \\
\hline 2859432 & CAU-140 SOIL DRUM 12 & DRUM-55GAL & & & & & & & & & & \\
\hline 2859433 & CAU-140 SOIL DRUM 13 & DRUM-55GAL & & & & & & & & & & \\
\hline 2859434 & CAU-140 SOIL DRUM 14 & DRUM-55GAL & & & & & & & & & & \\
\hline 2859435 & CAU-140 SOIL DRUM 15 & DRUM-55GAL & & & & & & & & & & \\
\hline 2865621 & BLDG 5-32 DRUM & DRUM & ACTIVE & NV ST PLN-NAD27 & & & & & & & & \\
\hline 2866202 & RWMS 5 ANIMAL & $\mathrm{BIO}$ & & & & & & & & & & \\
\hline 2866204 & RWMS 5 PLANT & BIO-VEG & & & & & & & & & & \\
\hline 2866863 & MERCURY HWY/5-01 ROAD & $\mathrm{BIO}$ & & & & & & & & & & \\
\hline 2875988 & MERCURY HWYICANE SPRGS INT. & AMS & & & & & & & & & & \\
\hline 2875989 & 28-03 AND CANE SPRNGS INT. & AMS & & & & & & & & & & \\
\hline
\end{tabular}





\section{APPENDIX D}

\section{AREA 5 RWMS WIND DATA}


This page intentionally left blank 


\section{AREA 5 RWMS WIND DATA}

The following wind rose diagrams summarize hourly wind speed and direction data on a monthly basis for the 1994 through 2004 period of record at the Area 5 RWMS Meteorology Station. Velocity groups are represented by color. 1 knot $=0.514$ meters per second $=1.151$ miles per hour. Sixteen wind source directions are represented by the petals, where North 360 degrees is the top petal, and East 90 degrees the right-most petal. Percent frequency is represented by the length of the petals.

The wind roses are from the Air Resources Laboratory, Special Operations and Research Division. Further Nevada Test Site wind information is available from the DOE web site: http://www.sord.nv.doe.gov/products/climate/wind-roses/MEDA.
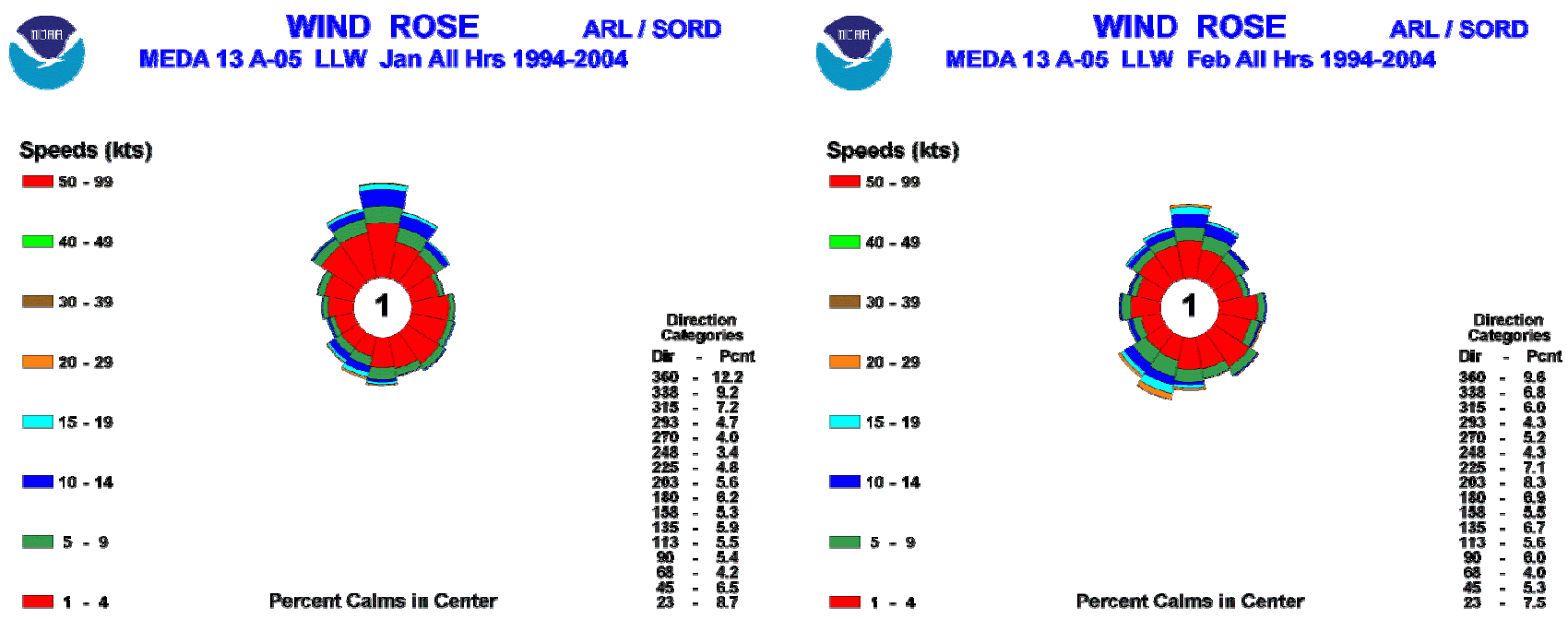

Percent Calms in Center
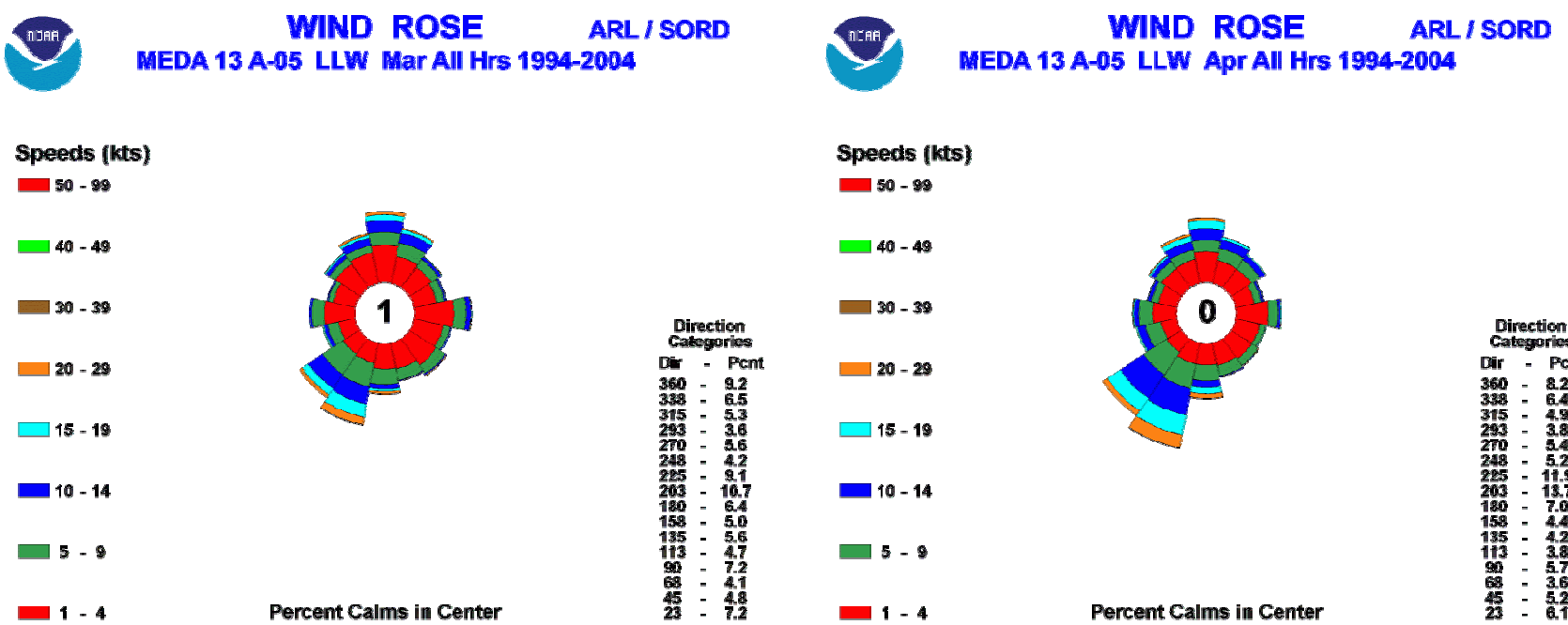

ARL/SORD

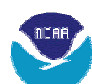

MEDA 13 A-05 LLW Apr All Hrs 1994-2004

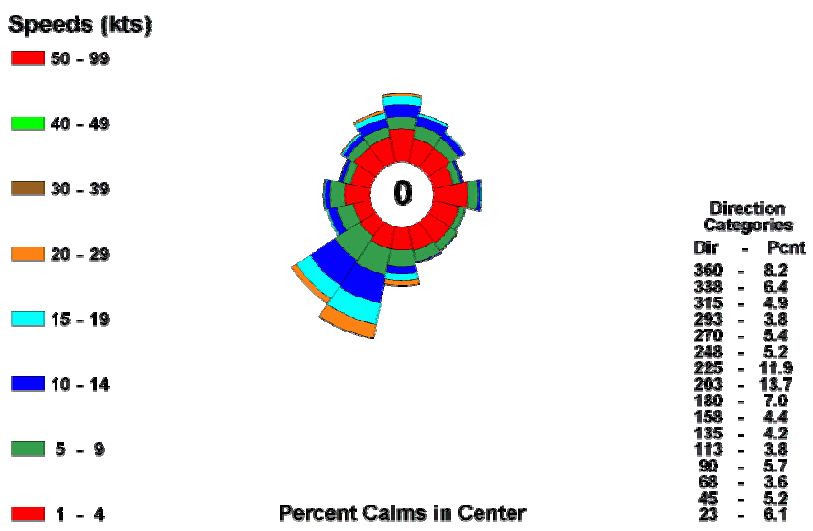




\section{WIND ROSE ARL/SORD MEDA 13 A-05 LLW May All Hrs 1994-2004}

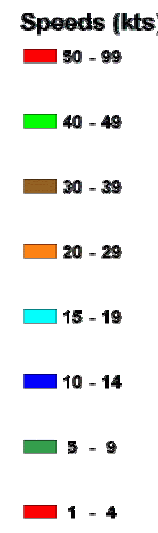

ARL/SORD

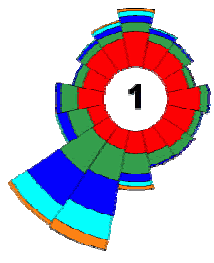

Percent Calms in Center

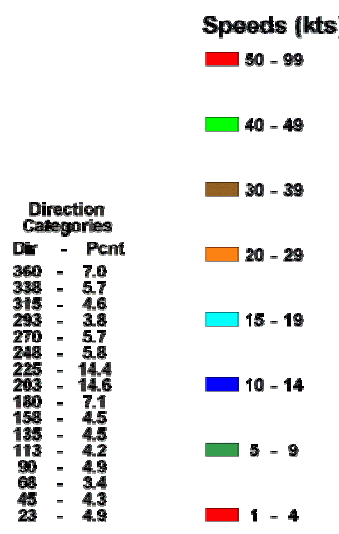

MEDA 13 A-05 LLW Jun All Hrs 1994-2004

ARL / SORD

Speeds (kts)

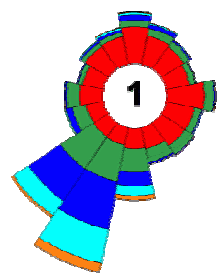

Percent Calms in Center

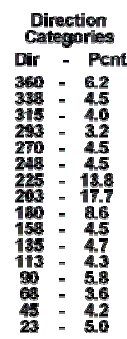

WIND ROSE MEDA 13 A-05 LLW Jul All Hrs 1994-2004

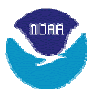

Speeds (kts)

50 - 99

$\square 0-49$

$30-39$

$\square 20-29$

$\square 15$ - 19

10 - 14

$5-9$

$1-4$

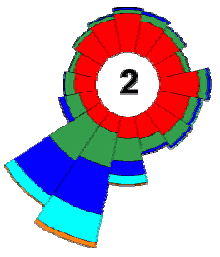

Percent Calms in Center

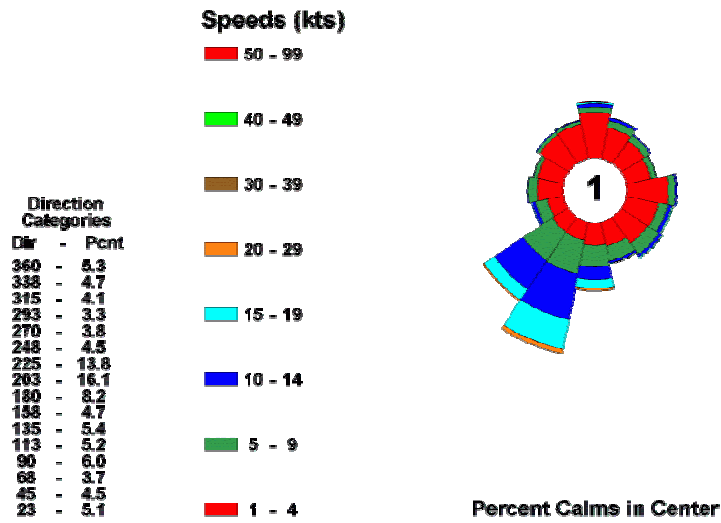

Percent Calms in Center
WIND ROSE ARL/SORD MEDA 13 A-05 LLW Aug All Hrs 1994-2004

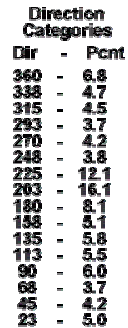


WIND ROSE ARL/SORD MEDA 13 A-05 LLW Sep All Hrs 1994-2004.

Speeds (kts)

50 - 99

$\square 40-49$

- 30 - 39

$\square 20-29$

$\square 15-19$

D10 - 14

$5-9$

a $1-4$

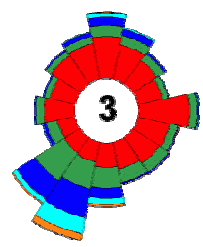

Percent Calms in Center

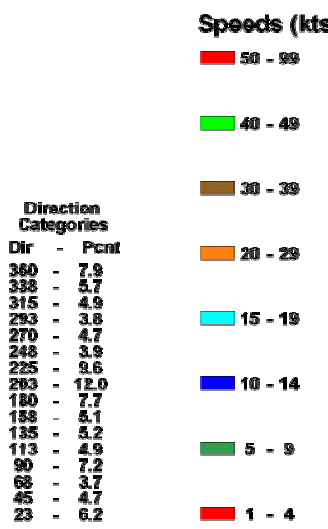

WIND ROSE

MEDA 13 A-05 LLW Oct All Hrs 1994-2004

ARL / SORD

Speeds (kts)

5a - 99

10 - 49

39

$20-28$

15 - 19

10 - 14

Percent Calms in Center

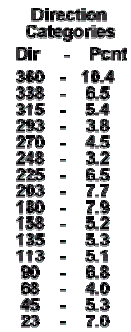

WIND ROSE

ARL/ SORD

MEDA 13 A-05 LLW Nov All Hrs 1994-2004

Speeds (kts)

- 50 - 99

$\square$ 40-49

- 30 - 39

$\square 20-29$

$\square 15-19$

C10 - 14

$5-9$

다 -4

Percent Calms in Center

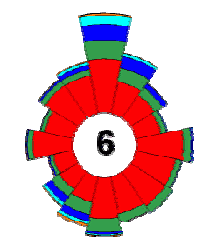

Direction

Catcogories
Dir - Pent
Det

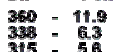

215 :

$278:-3$.

2050 :

158
135
113
113
10

$113=5.5$
9050.8
65
$45=5.0$
$23=7.3$
WIND ROSE

MEDA 13 A-05 LLW Dec All Hrs 1994-2004

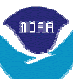

Speeds (kts)

ए 50 - 99

$\square$ - 40 - 49

- 30 - 39

$\square 20-29$

$\square 15-19$

10 - 14

5-9

- 1 - 4

Percent Calms in Center

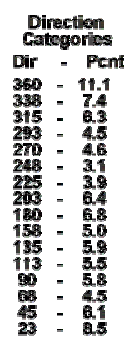


This page intentionally left blank

D-4 


\section{APPENDIX E}

\section{BOREHOLE DATA AND WELL DETAILS}


This page intentionally left blank 


\section{SCIENCE TRENCH BOREHOLE ST-1 COMPLETION DIAGRAM}

Source: Reynolds Electrical \& Engineering Co. Inc, 1993. Hydrogeologic Data for the Science Trench Boreholes at the Area 5 RWMS, Nevada Test Site

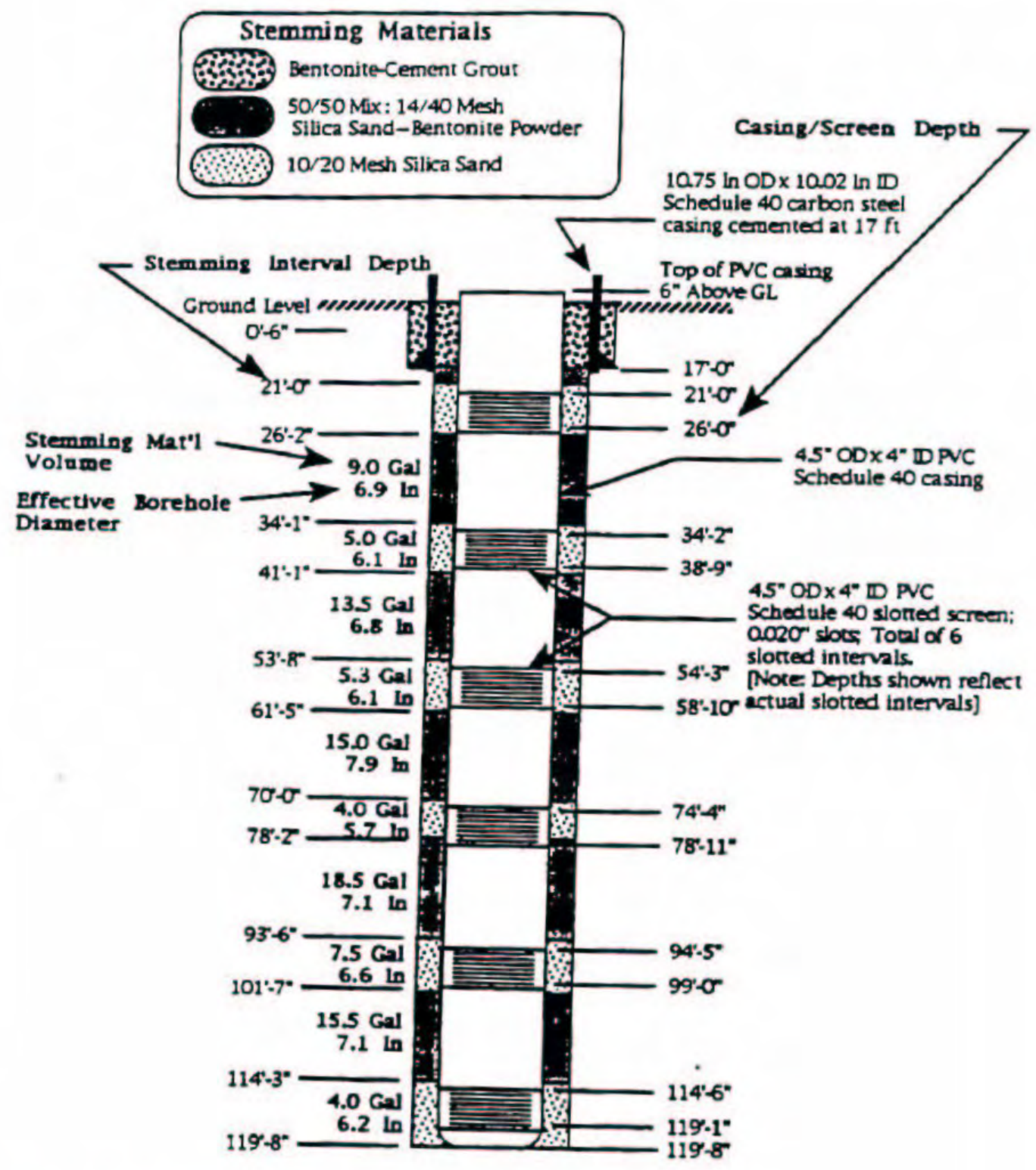

Figure I.1. Completion details for boreholes ST-1. 


\section{SCIENCE TRENCH BOREHOLE ST-2A COMPLETION DIAGRAM}

Source: Reynolds Electrical \& Engineering Co. Inc, 1993. Hydrogeologic Data for the Science Trench Boreholes at the Area 5 RWMS, Nevada Test Site

Stemming Materials
Sorso Mix: $14 / 40$ Mesh
Silica Sand-Bentonite Powder
10220 Mesh Silica Sand

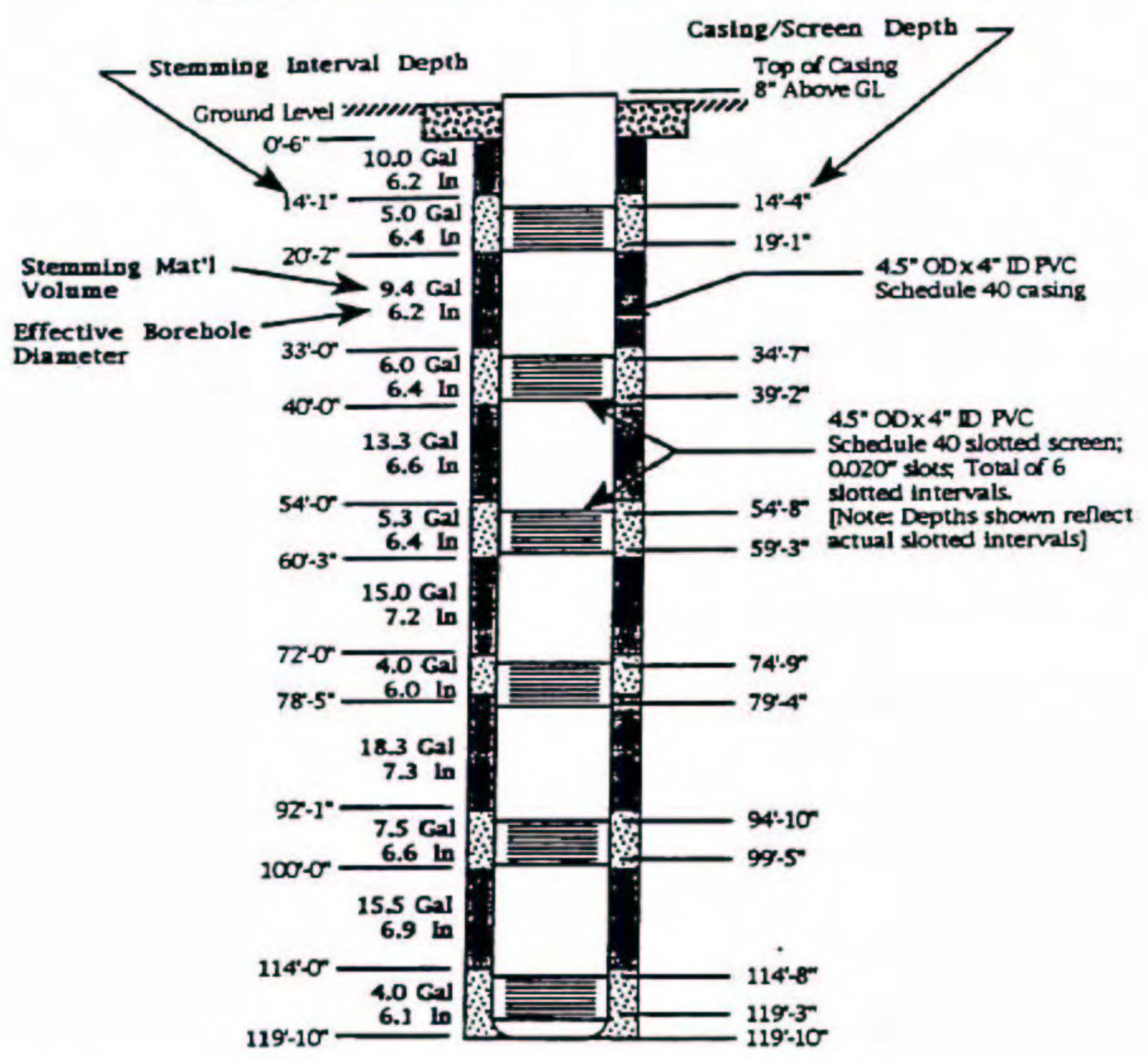

Figure 1.2. Completion details for boreholes ST-2A. 


\section{SCIENCE TRENCH BOREHOLE ST-4A COMPLETION DIAGRAM}

Source: Reynolds Electrical \& Engineering Co. Inc, 1993. Hydrogeologic Data for the Science Trench Boreholes at the Area 5 RWMS, Nevada Test Site
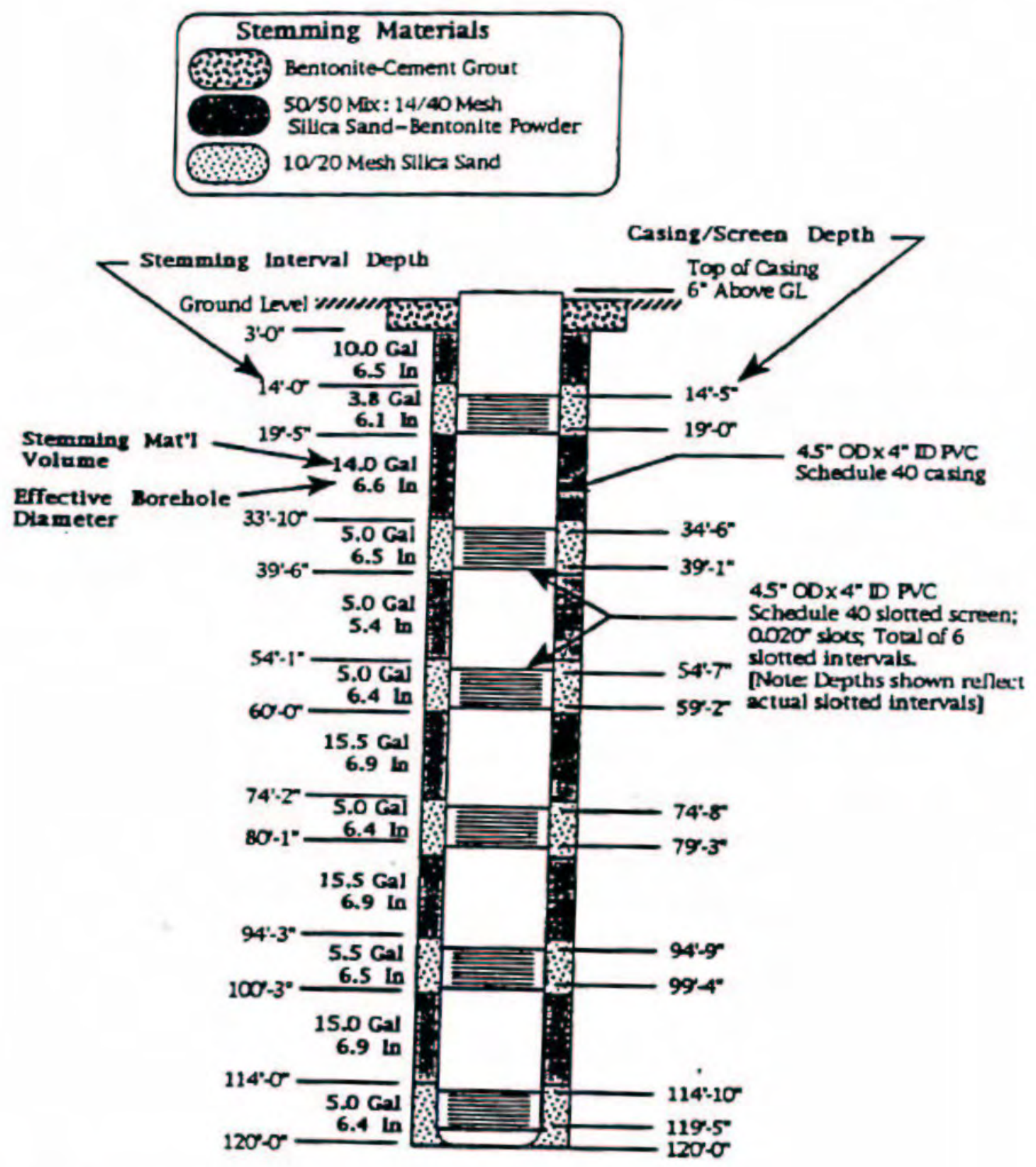

Figure I.3. Completion details for boreholes ST-4A. 


\section{SCIENCE TRENCH BOREHOLE ST-6A COMPLETION DIAGRAM}

Source: Reynolds Electrical \& Engineering Co. Inc, 1993. Hydrogeologic Data for the Science Trench Boreholes at the Area 5 RWMS, Nevada Test Site

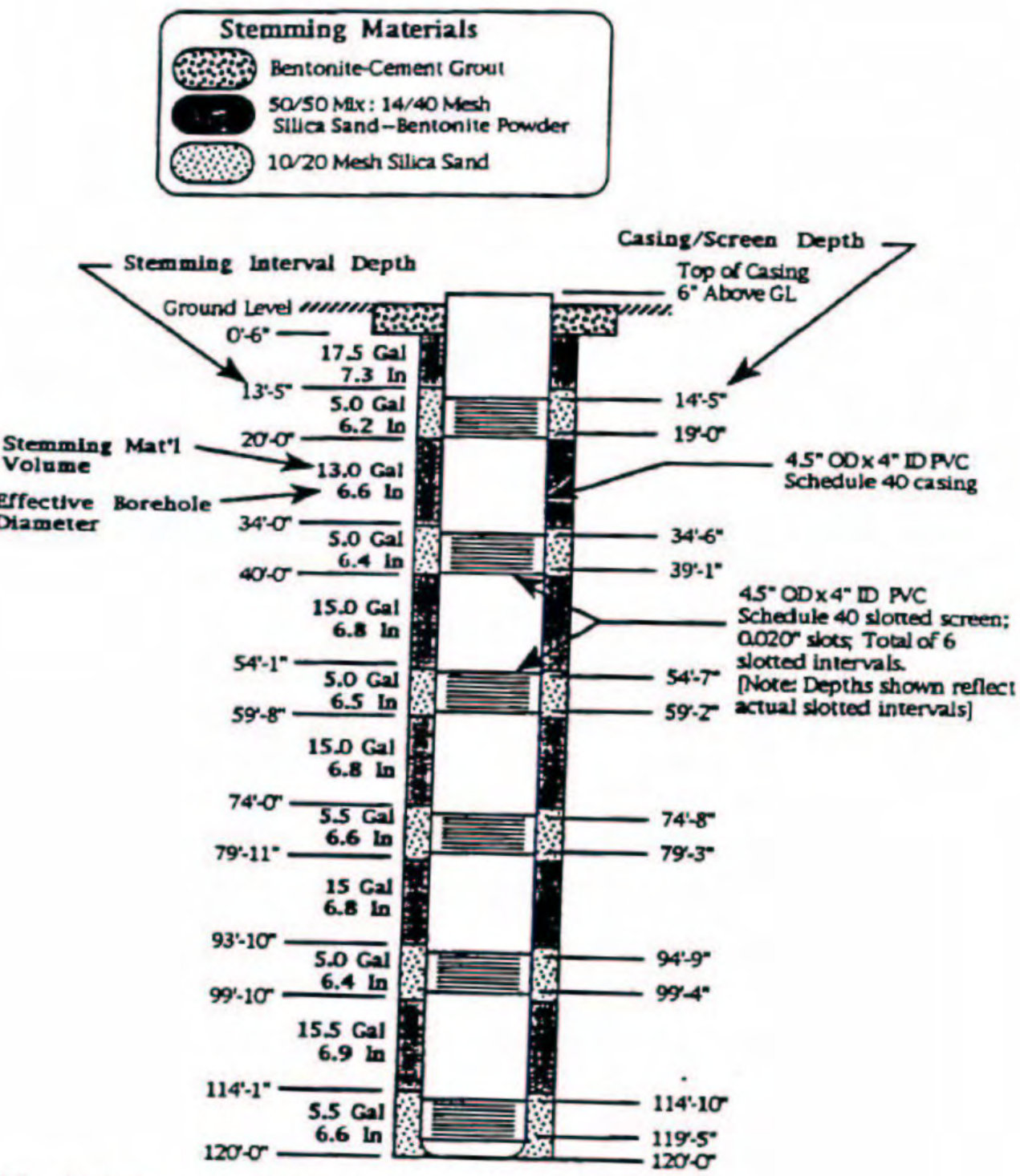

Figure I.4. Completion details for boreholes ST-6A. 


\section{UE5PW-1 BORING LOG}

Source: REECo, February 1994. Site Characterization and Monitoring data from Area 5 Pilot Wells, NTS, Nye County, Nevada. DOE/NV/11432—74.

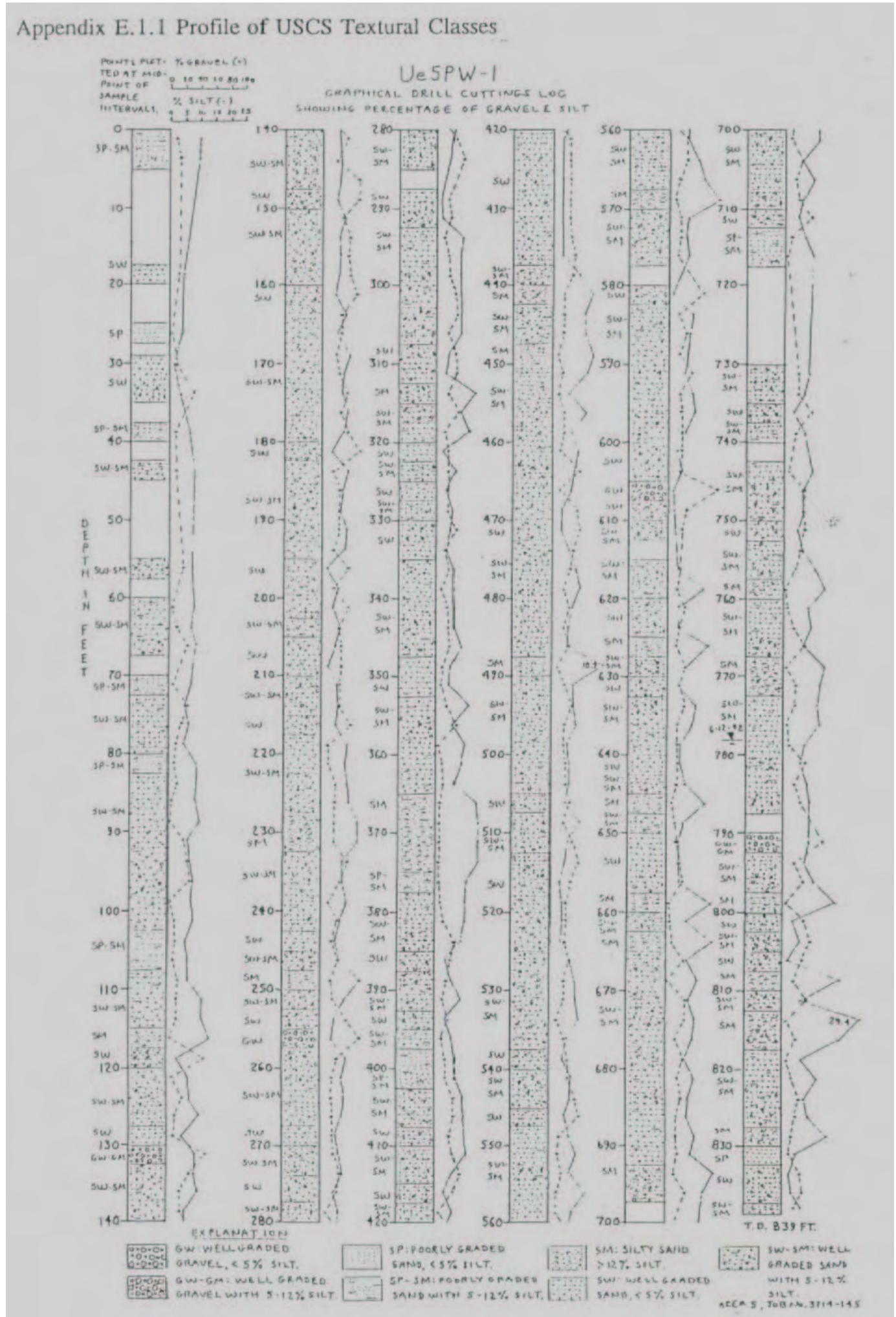




\section{UE5PW-2 BORING LOG}

Source: REECo, February 1994. Site Characterization and Monitoring data from Area 5 Pilot Wells, NTS, Nye County, Nevada. DOE/NV/11432-74.

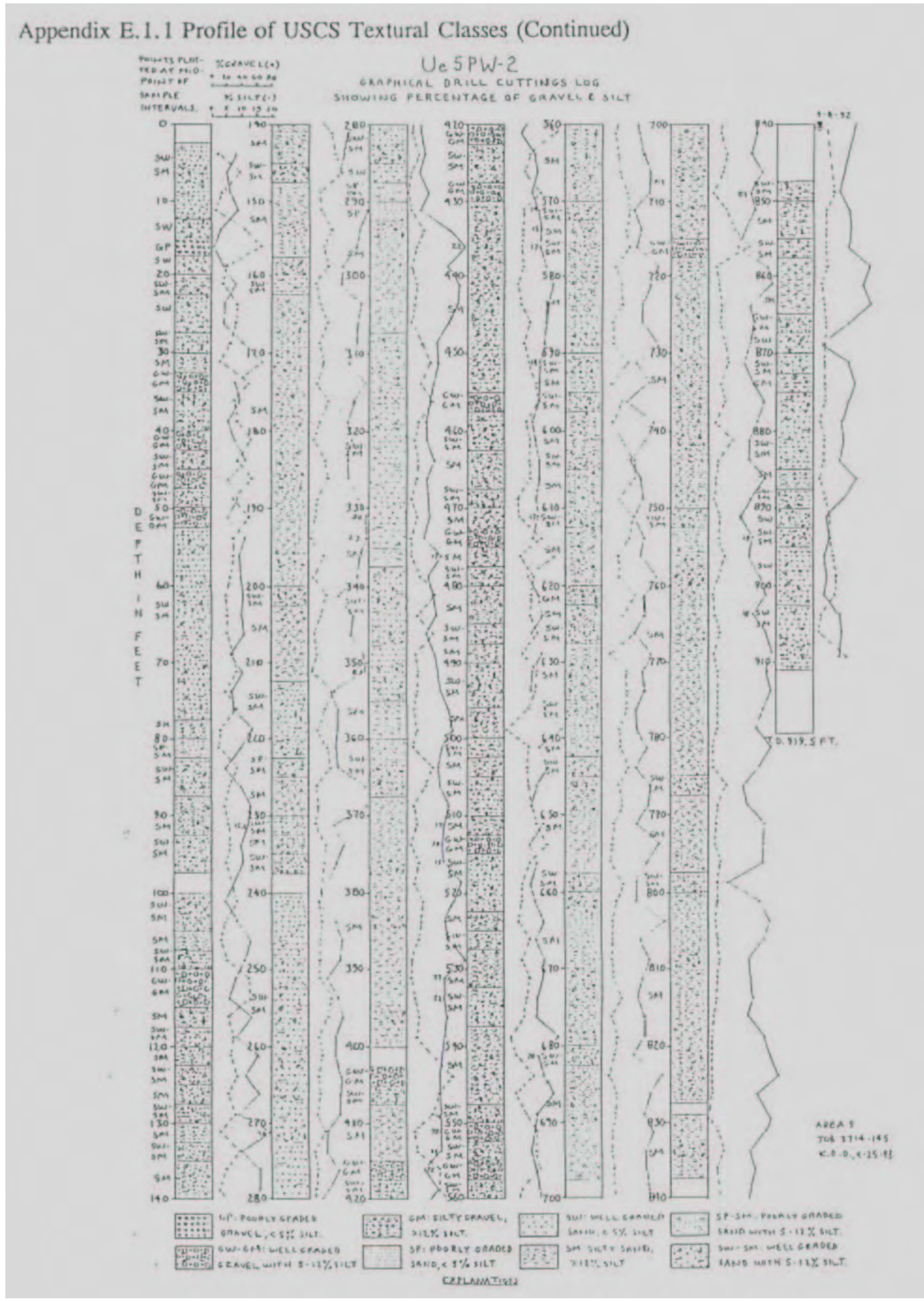




\section{UE5PW-3 BORING LOG}

Source: REECo, February 1994. Site Characterization and Monitoring data from Area 5 Pilot Wells, NTS, Nye County, Nevada. DOE/NV/11432-74

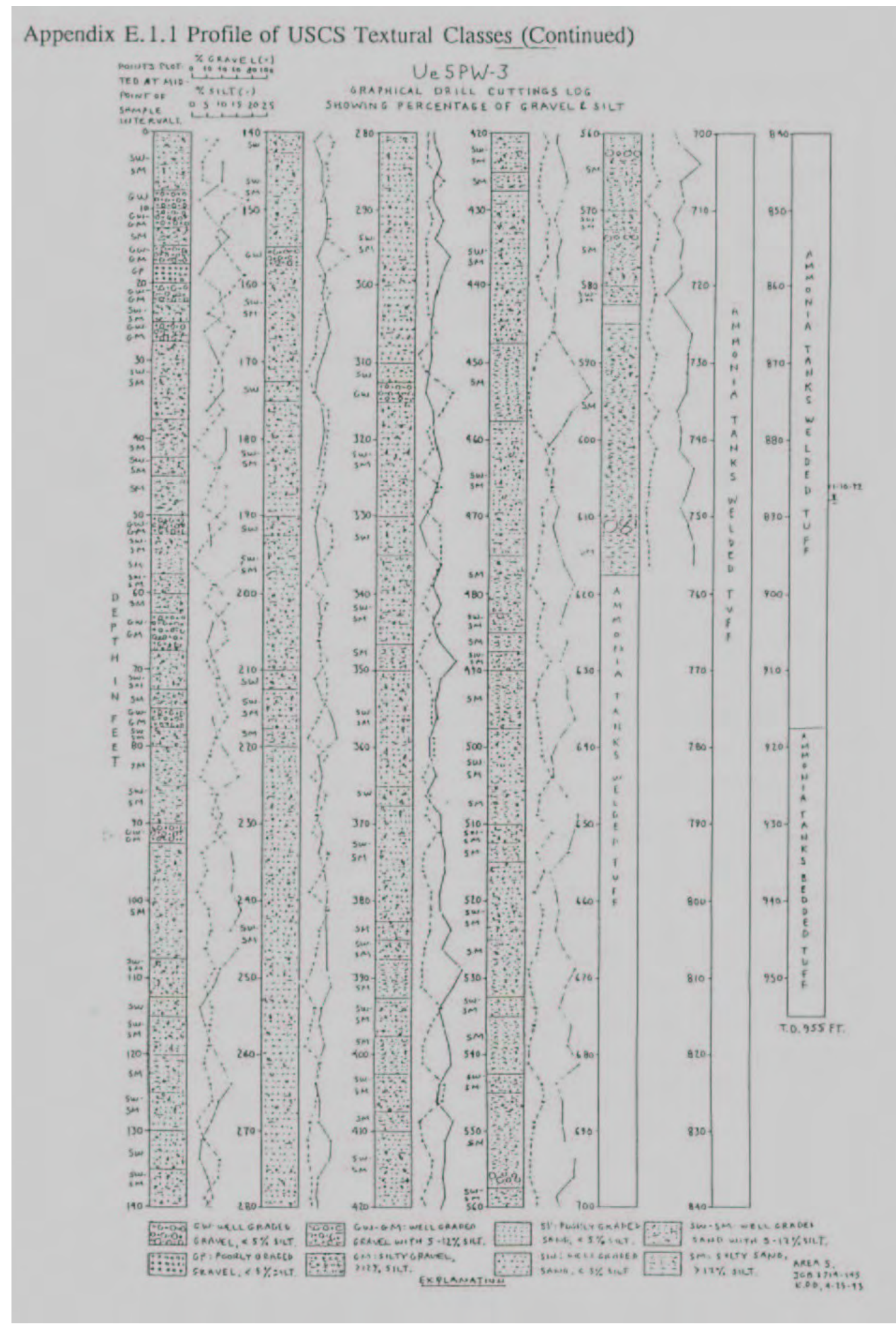




\section{UE5PW-1 WELL COMPLETION DIAGRAM}

Source: REECo, February 1994. Site Characterization and Monitoring data from Area 5 Pilot Wells, NTS, Nye County, Nevada. DOE/NV/11432_74.

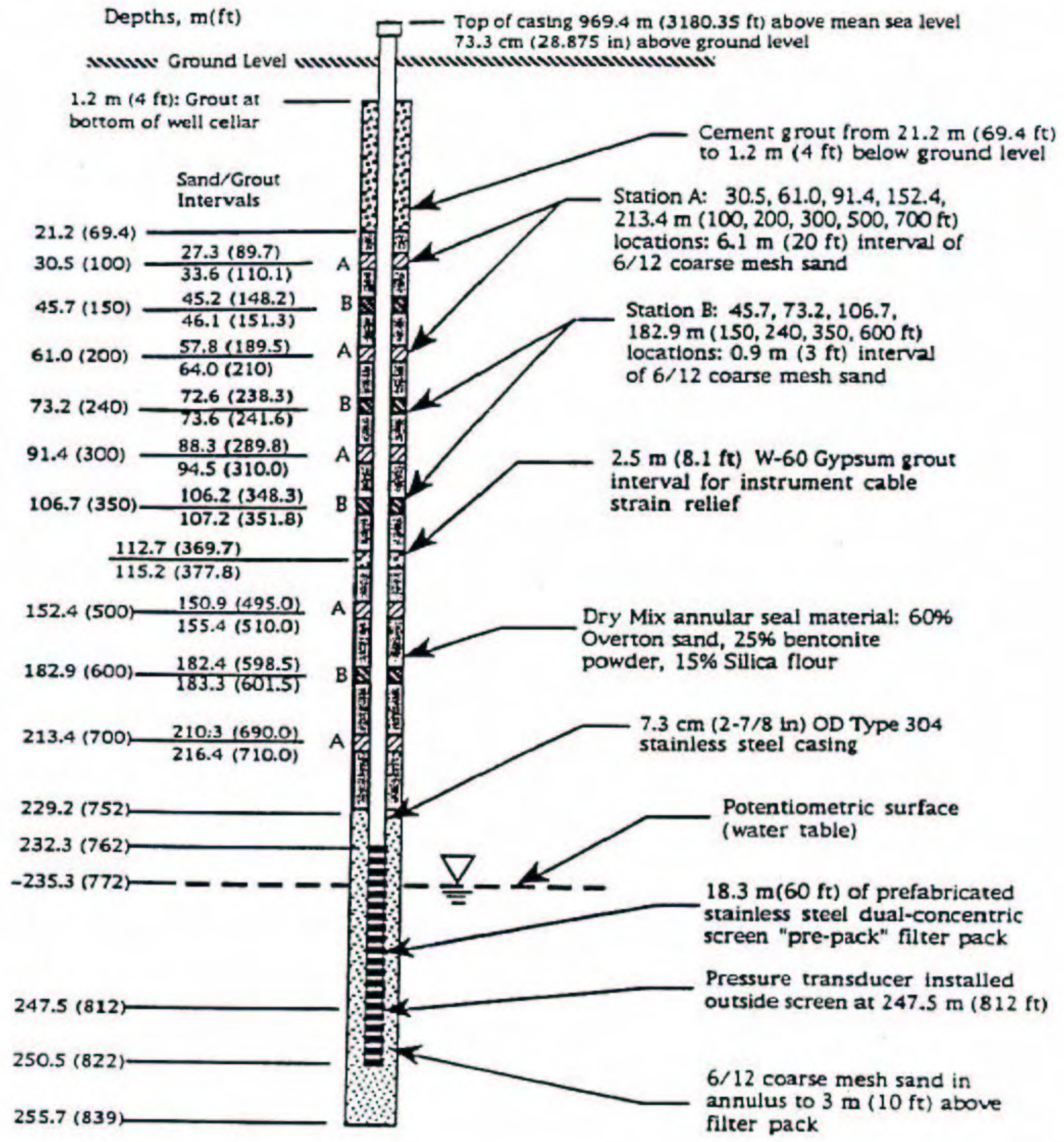

E-8 


\section{UE5PW-2 WELL COMPLETION DIAGRAM}

Source: REECo, February 1994. Site Characterization and Monitoring data from Area 5 Pilot Wells, NTS, Nye County, Nevada. DOE/NV/11432_74.

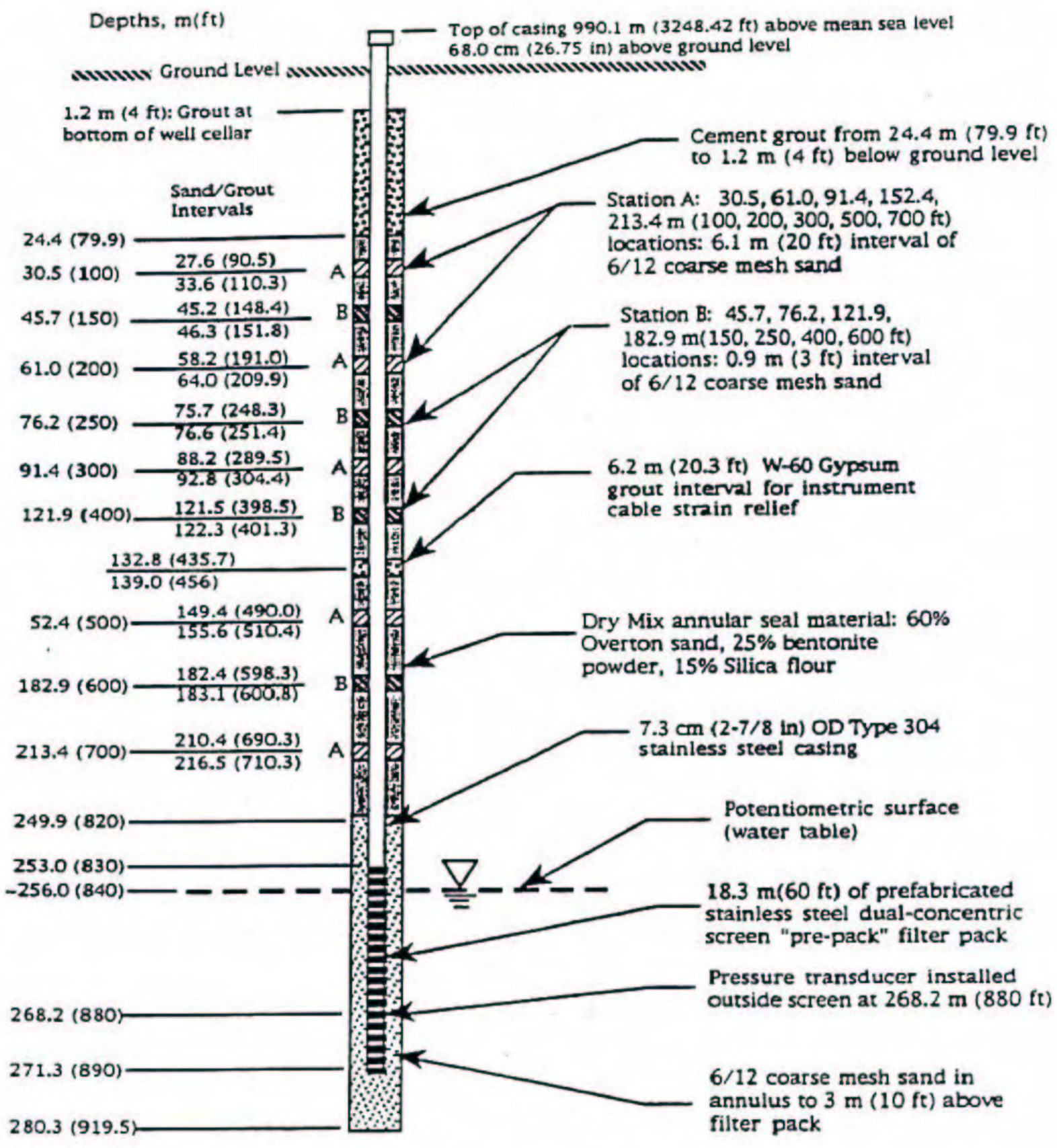




\section{UE5PW-3 WELL COMPLETION DIAGRAM}

Source: REECo, February 1994. Site Characterization and Monitoring data from Area 5 Pilot Wells, NTS, Nye County, Nevada. DOE/NV/11432—74.

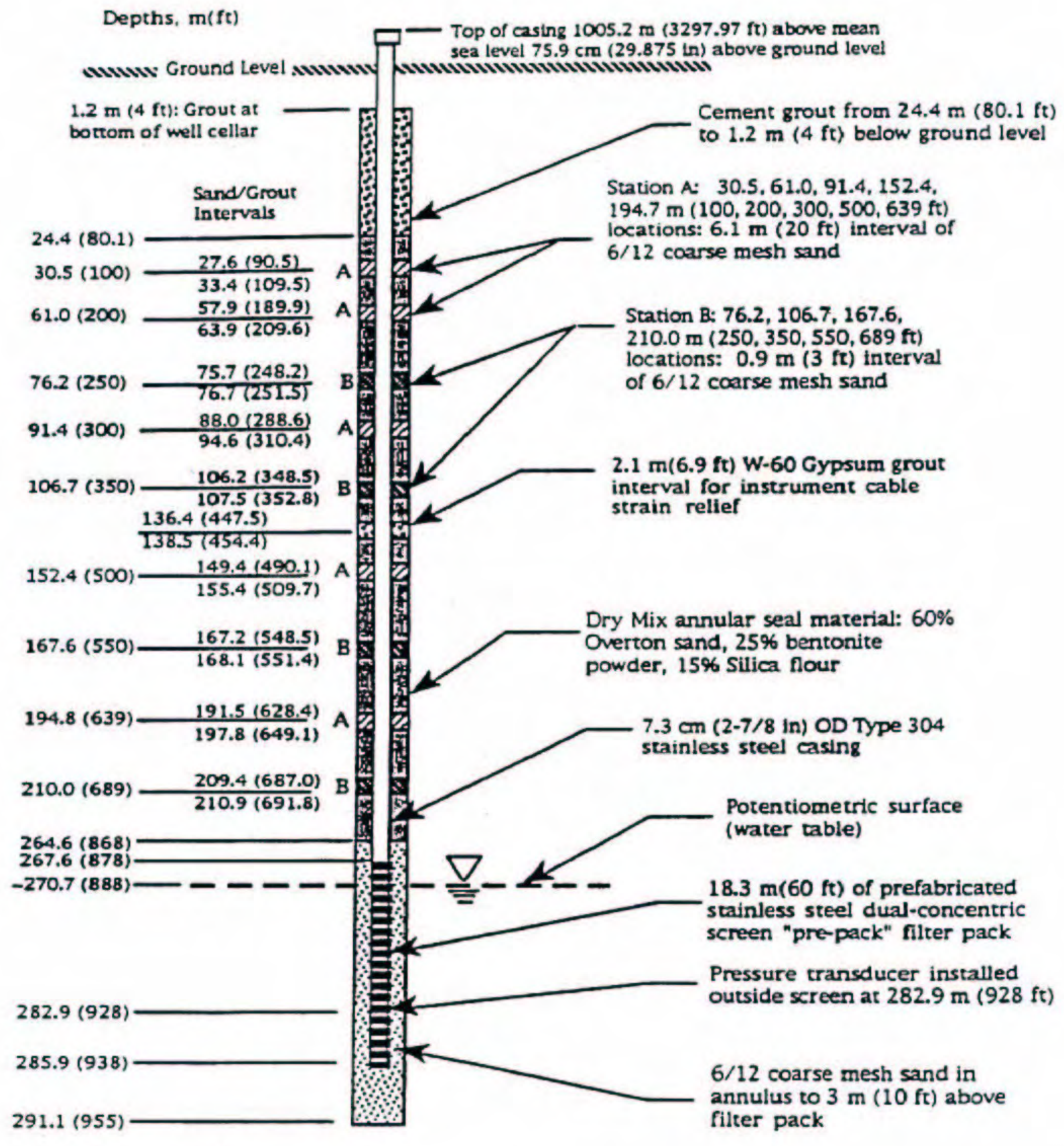

E-10 


\section{APPENDIX F \\ GROUNDWATER QUALITY DATA SUMMARY}


This page intentionally left blank 
MARCH 1993 THROUGH OCTOBER 2004 GROUNDWATER MONITORING

\begin{tabular}{|c|c|c|c|c|c|c|c|c|c|c|c|}
\hline Well & Parameter & $\begin{array}{c}\text { Total } \\
\text { Number of } \\
\text { Samples } \\
\text { Analyzed }\end{array}$ & $\begin{array}{c}\text { Number of } \\
\text { Detections } \\
\text { of } \\
\text { Parameter }\end{array}$ & Units & $\begin{array}{c}\text { Investigation } \\
\text { Level }\end{array}$ & Minimum & Maximum & $\begin{array}{c}\text { Mean of } \\
\text { Detected } \\
\text { Values } \\
\text { Above MDL }\end{array}$ & $\begin{array}{l}\text { Standard } \\
\text { Deviation }\end{array}$ & $\begin{array}{c}\text { Coefficient } \\
\text { of Variance } \\
\%\end{array}$ & $\begin{array}{l}\text { Latest Published } \\
\text { (10/19/2004 } \\
\text { Sample })\end{array}$ \\
\hline \multicolumn{12}{|c|}{ UE5PW-1 } \\
\hline & $\mathrm{pH}$ & 29 & 29 & unitless & $<7.6$ or $>9.2$ & 7.91 & 8.63 & 8.35 & 0.14 & 2 & 8.30 \\
\hline & Specific Conductance & 29 & 29 & mmhos/cm & 0.440 & 0.320 & 0.401 & 0.376 & 0.014 & 4 & 0.372 \\
\hline & Total Organic Carbon ${ }^{a}$ & 27 & 7 & $\mathrm{mg} / \mathrm{l}$ & 1 & 0.2 & 0.64 & 0.44 & 0.16 & 37 & 0.58 \\
\hline & Total Organic Halides $^{a}$ & 29 & $3^{b}$ & ug/l & 50 & 12 & 20 & 17.3 & 4.6 & 27 & $<5.2$ \\
\hline & Tritium & 21 & 1 & $\mathrm{pCi} / \mathrm{l}$ & 2000 & $<20$ & $33.96^{c}$ & 33.96 & 0 & 0 & $<20$ \\
\hline & $\mathrm{Ca}$ & 16 & 16 & $\mathrm{mg} / \mathrm{l}$ & & 12.5 & 15.5 & 14.04 & 0.9 & 6 & 13.1 \\
\hline & $\mathrm{Fe}$ & 24 & 20 & $\mathrm{mg} / \mathrm{l}$ & & 0.008 & 0.059 & 0.021 & 0.012 & 58 & $<0.028$ \\
\hline & $\mathrm{Mg}$ & 16 & 16 & $\mathrm{mg} / \mathrm{l}$ & & 4.5 & 6 & 5.1625 & 0.37 & 7 & 5.2 \\
\hline & Mn & 23 & 9 & $\mathrm{mg} / \mathrm{l}$ & & 0.0002 & 0.0066 & 0.0016 & 0.002 & 127 & $<0.0003$ \\
\hline & K & 16 & 16 & mg/l & & 5.21 & 6.96 & 6.37 & 0.46 & 7 & 6 \\
\hline & Si & 14 & 14 & mg/l & & 24.3 & 32 & 27.95 & 1.76 & 6 & 28 \\
\hline & $\mathrm{Na}$ & 24 & 24 & $\mathrm{mg} / \mathrm{l}$ & & 48 & 63.5 & 56.25 & 3.74 & 7 & 56.2 \\
\hline & $\mathrm{SO}_{4}$ & 21 & 21 & $\mathrm{mg} / \mathrm{l}$ & & 32 & 37.3 & 35.02 & 1.52 & 4 & 37.3 \\
\hline & $\mathrm{HCO}_{3}$ & 19 & 19 & $\mathrm{mg} / \mathrm{l}$ & & 117 & 157.5 & 129.45 & 10.6 & 8 & 138 \\
\hline & $\mathrm{Cl}$ & 22 & 22 & $\mathrm{mg} / \mathrm{l}$ & & 8.4 & 12.3 & 9.88 & 0.75 & 8 & 10.1 \\
\hline & $F$ & 19 & 19 & $\mathrm{mg} / \mathrm{l}$ & & 0.95 & 5.7 & 1.35 & 1.06 & 78 & 1 \\
\hline \multicolumn{12}{|c|}{ UE5PW-2 } \\
\hline & $\mathrm{pH}$ & 28 & 28 & unitless & $<7.6$ or $>9.2$ & 7.99 & 8.81 & 8.33 & 0.20 & 2 & 8.32 \\
\hline & Specific Conductance & 28 & 28 & mmhos/cm & 0.440 & 0.325 & 0.411 & 0.359 & 0.015 & 4 & 0.352 \\
\hline & Total Organic Carbon $^{a}$ & 28 & 5 & $\mathrm{mg} / \mathrm{l}$ & 1 & 0.39 & 0.90 & 0.61 & 0.19 & 32 & 0.90 \\
\hline & Total Organic Halides ${ }^{a}$ & 27 & 4 & ug/l & 50 & 3.7 & 23 & 11.6 & 8.8 & 77 & $<5.2$ \\
\hline & Tritium & 22 & 1 & $\mathrm{pCi} / \mathrm{l}$ & 2000 & $32.2^{d}$ & $32.2^{d}$ & 32.2 & 0 & 0 & $<20$ \\
\hline & $\mathrm{Ca}$ & 16 & 16 & $\mathrm{mg} / \mathrm{l}$ & & 14.8 & 17.55 & 16.1 & 0.79 & 5 & 15.7 \\
\hline & $\mathrm{Fe}$ & 23 & 16 & $\mathrm{mg} / \mathrm{l}$ & & 0.012 & 0.33 & 0.0869 & 0.0931 & 107 & $<0.028$ \\
\hline & $\mathrm{Mg}$ & 16 & 16 & $\mathrm{mg} / \mathrm{l}$ & & 5.68 & 7.1 & 6.52 & 0.036 & 6 & 6.7 \\
\hline & Mn & 22 & 7 & $\mathrm{mg} / \mathrm{l}$ & & 0.0002 & 0.11 & 0.0211 & 0.0409 & 194 & $<0.0003$ \\
\hline & K & 16 & 16 & mg/l & & 3.83 & 6.2 & 5.25 & 0.51 & 10 & 5.1 \\
\hline & $\mathrm{Si}$ & 14 & 14 & $\mathrm{mg} / \mathrm{l}$ & & 23.8 & 29.45 & 27.43 & 1.47 & 5 & 27.9 \\
\hline & $\mathrm{Na}$ & 23 & 23 & $\mathrm{mg} / \mathrm{l}$ & & 44.35 & 55 & 48.55 & 3.18 & 7 & 48.6 \\
\hline & $\mathrm{SO}_{4}$ & 22 & 22 & mg/l & & 26.4 & 31 & 28.55 & 1.02 & 4 & 29.6 \\
\hline & $\mathrm{HCO}_{3}$ & 20 & 20 & $\mathrm{mg} / \mathrm{l}$ & & 110 & 150 & 127.83 & 9.79 & 8 & 139 \\
\hline & $\mathrm{Cl}$ & 21 & 21 & $\mathrm{mg} / \mathrm{l}$ & & 7.4 & 9.9 & 8.65 & 0.61 & 7 & 8.9 \\
\hline & $F$ & 19 & 19 & $\mathrm{mg} / \mathrm{l}$ & & 0.81 & 1.3 & 0.98 & 0.14 & 14 & 0.9 \\
\hline
\end{tabular}




\begin{tabular}{|c|c|c|c|c|c|c|c|c|c|c|c|}
\hline Well & Parameter & \begin{tabular}{|c|} 
Total \\
Number of \\
Samples \\
Analyzed
\end{tabular} & $\begin{array}{c}\text { Number of } \\
\text { Detections } \\
\text { of } \\
\text { Parameter }\end{array}$ & Units & $\begin{array}{c}\text { Investigation } \\
\text { Level }\end{array}$ & Minimum & Maximum & $\begin{array}{c}\text { Mean of } \\
\text { Detected } \\
\text { Values } \\
\text { Above MDL }\end{array}$ & $\begin{array}{l}\text { Standard } \\
\text { Deviation }\end{array}$ & $\begin{array}{c}\text { Coefficient } \\
\text { of Variance } \\
\%\end{array}$ & $\begin{array}{c}\text { Latest Published } \\
\text { (10/19/2004 } \\
\text { Sample })\end{array}$ \\
\hline \multicolumn{12}{|c|}{ UE5PW-3 } \\
\hline & $\mathrm{pH}$ & 30 & 30 & unitless & $<7.6$ or $>9.2$ & 8.13 & 8.87 & 8.35 & 0.20 & 2 & 8.24 \\
\hline & Specific Conductance & 30 & 30 & $\mathrm{mmhos} / \mathrm{cm}$ & 0.440 & 0.338 & 0.384 & 0.367 & 0.011 & 3 & 0.365 \\
\hline & Total Organic Carbon ${ }^{a}$ & 27 & 8 & $\mathrm{mg} / \mathrm{l}$ & 1 & 0.22 & 1.7 & 0.65 & 0.46 & 71 & 0.83 \\
\hline & Total Organic Halides ${ }^{a}$ & 27 & $2^{b}$ & ug/l & 50 & 9 & 20 & 14.5 & 7.8 & 54 & $<5.2$ \\
\hline & Tritium & 22 & 0 & $\mathrm{pCi} / \mathrm{l}$ & 2000 & $<20$ & $<20$ & NA & NA & NA & $<20$ \\
\hline & $\mathrm{Ca}$ & 16 & 16 & $\mathrm{mg} / \mathrm{l}$ & & 15 & 17.1 & 16 & 0.55 & 3 & 15.6 \\
\hline & $\mathrm{Fe}$ & 24 & 15 & $\mathrm{mg} / \mathrm{l}$ & & 0.0088 & 0.0453 & 0.02111 & 0.0116 & 55 & $<0.028$ \\
\hline & $\mathrm{Mg}$ & 16 & 16 & $\mathrm{mg} / \mathrm{l}$ & & 5.7 & 6.4 & 5.9 & 0.18 & 3 & 5.9 \\
\hline & $\mathrm{Mn}$ & 23 & 8 & $\mathrm{mg} / \mathrm{l}$ & & 0.0002 & 0.0009 & 0.00045 & 0.0003 & 73 & $<0.0003$ \\
\hline & K & 16 & 16 & $\mathrm{mg} / \mathrm{l}$ & & 2.4 & 4.8 & 4.1 & 0.58 & 14 & 4 \\
\hline & Si & 14 & 14 & $\mathrm{mg} / \mathrm{l}$ & & 26.4 & 31 & 27.65 & 1.12 & 4 & 27.3 \\
\hline & $\mathrm{Na}$ & 24 & 24 & $\mathrm{mg} / \mathrm{l}$ & & 47.6 & 58.5 & 53.12 & 3.2 & 6 & 52.3 \\
\hline & $\mathrm{SO}_{4}$ & 22 & 22 & $\mathrm{mg} / \mathrm{l}$ & & 29 & 33 & 31.42 & 1.09 & 3 & 32 \\
\hline & $\mathrm{HCO}_{3}$ & 20 & 20 & $\mathrm{mg} / \mathrm{l}$ & & 115 & 138.5 & 126.16 & 6.68 & 5 & 136 \\
\hline & $\mathrm{Cl}$ & 22 & 22 & $\mathrm{mg} / \mathrm{l}$ & & 7.6 & 11.8 & 9.12 & 0.87 & 10 & 9.4 \\
\hline & $F$ & 19 & 18 & $\mathrm{mg} / \mathrm{l}$ & & 0.78 & 1.26 & 0.95 & 0.12 & 13 & 0.8 \\
\hline \multicolumn{12}{|c|}{ 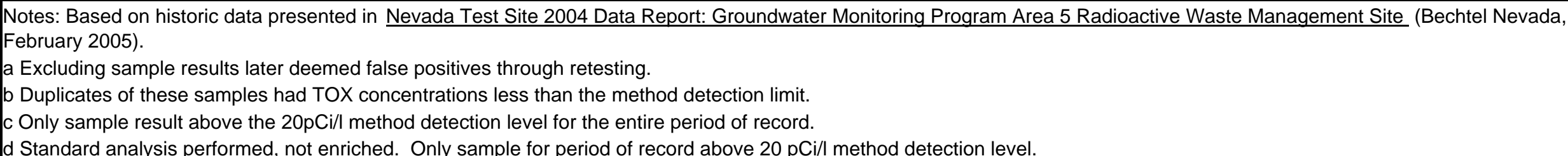 } \\
\hline
\end{tabular}




\section{DISTRIBUTION LIST}

\section{U.S. Department of Energy}

Jhon Carilli 4 (controlled)

Waste Management Project

Office of Environmental Management

U.S. Department of Energy

National Nuclear Security Administration

Nevada Site Office

P.O. Box 98518, M/S 505

Las Vegas, NV 89193-8518

Angela Colarusso 1 (uncontrolled)

Waste Management Project

Office of Environmental Management

U.S. Department of Energy

National Nuclear Security Administration

Nevada Site Office

P.O. Box 98518, M/S 505

Las Vegas, NV 89193-8518

B.M. Crowe 1 (uncontrolled)

Apogen Technologies

U.S. Department of Energy

National Nuclear Security Administration

Nevada Site Office

P.O. Box 98518, M/S 505

Las Vegas, NV 89193-8518

Sabine Curtis 1 (uncontrolled)

Environmental Restoration Project

Office of Environmental Management

U.S. Department of Energy

National Nuclear Security Administration

Nevada Site Office

P.O. Box 98518, M/S 505

Las Vegas, NV 89193-8518

Ken Small 1 (uncontrolled)

Waste Management Project

Office of Environmental Management

U.S. Department of Energy

National Nuclear Security Administration

Nevada Site Office

P.O. Box 98518, M/S 505

Las Vegas, NV 89193-8518 


\section{DISTRIBUTION LIST (continued)}

U.S. Department of Energy 1 (electronic uncontrolled)

National Nuclear Security Administration

Nevada Site Office

Technical Library

P.O. Box 98518, M/S 505

Las Vegas, NV 89193-8518

U.S. Department of Energy 1 (electronic uncontrolled)

National Nuclear Security Administration

Nevada Site Office

Public Reading Facility

c/o Nuclear Testing Archive

P.O. Box 98521, M/S 400

Las Vegas, NV 89193-8521

U.S. Department of Energy 1 (electronic uncontrolled)

Office of Scientific and Technical Information)

Post Office Box 62

Oak Ridge, Tennessee 37831-0062 


\section{Bechtel Nevada}

Max Dolenc 1 (uncontrolled)

Bechtel Nevada

P.O. Box 98521, M/S NSF083

Las Vegas, NV 89193-8521

David Hudson 1 (uncontrolled)

Bechtel Nevada

P.O. Box 98521, M/S NTS273

Las Vegas, NV 89193-8521

Renee Hudson 1 (uncontrolled)

Bechtel Nevada

P.O. Box 98521 M/S NLV 084

Las Vegas, NV 89193-8521

Mike Millard 1 (uncontrolled)

Bechtel Nevada

P.O. Box 98521, M/S NTS404

Las Vegas, NV 89193-8521

Steve Nacht 1 (uncontrolled)

Bechtel Nevada

P.O. Box 98521, M/S NSF083

Las Vegas, NV 89193-8521

Stuart Rawlinson 1 (uncontrolled)

Bechtel Nevada

P.O. Box 98521, M/S NTS416

Las Vegas, NV 89193-8521
Greg Shott 1 (uncontrolled)

Bechtel Nevada

P.O. Box 98521, M/S NSF081

Las Vegas, NV 89193-8521

Dan Tobiason 1 (uncontrolled)

Bechtel Nevada

P.O. Box 98521, M/S NTS416

Las Vegas, NV 89193-8521

Denise Wieland 1 (uncontrolled)

Bechtel Nevada

P.O. Box 98521, M/S NTS416

Las Vegas, NV 89193-8521

Vefa Yucel 1 (uncontrolled)

Bechtel Nevada

P.O. Box 98521, M/S NLV081

Las Vegas, NV 89193-8521 
This page intentionally left blank

Distrib-4 